\title{
BARRIER ISSUES TO THE UTILIZATION OF BIOMASS
}

\author{
Final Technical Report
}

Prepared for:

AAD Document Control

U.S. Department of Energy

National Energy Technology Laboratory

626 Cochrans Mill Road

PO Box 10940, MS 921-103

Pittsburgh, PA 15236-0940

DOE Cooperative Agreement No. DE-FC26-00NT41014

Performance Monitor: Philip M. Goldberg

Prepared by:

Bruce C. Folkedahl

Jay R. Gunderson

Darren D. Schmidt

Greg F. Weber

Christopher J. Zygarlicke

Energy \& Environmental Research Center University of North Dakota

PO Box 9018

Grand Forks, ND 58202-9018 


\section{DOE DISCLAIMER}

This report was prepared as an account of work sponsored by an agency of the United States Government. Neither the United States Government, nor any agency thereof, nor any of their employees makes any warranty, express or implied, or assumes any legal liability or responsibility for the accuracy, completeness, or usefulness of any information, apparatus, product, or process disclosed or represents that its use would not infringe privately owned rights. Reference herein to any specific commercial product, process, or service by trade name, trademark, manufacturer, or otherwise does not necessarily constitute or imply its endorsement, recommendation, or favoring by the United States Government or any agency thereof. The views and opinions of authors expressed herein do not necessarily state or reflect those of the United States Government or any agency thereof.

This report is available to the public from the National Technical Information Service, U.S. Department of Commerce, 5285 Port Royal Road, Springfield, VA 22161; phone orders accepted at (703) $487-4650$.

\section{ACKNOWLEDGMENT}

This report was prepared with the support of the U.S. Department of Energy (DOE) National Energy Technology Laboratory Cooperative Agreement No. DE-FC26-00NT41014. However, any opinions, findings, conclusions, or recommendations expressed herein are those of the authors(s) and do not necessarily reflect the views of DOE.

\section{EERC DISCLAIMER}

LEGAL NOTICE This research report was prepared by the Energy \& Environmental Research Center (EERC), an agency of the University of North Dakota, as an account of work sponsored by DOE. Because of the research nature of the work performed, neither the EERC nor any of its employees makes any warranty, express or implied, or assumes any legal liability or responsibility for the accuracy, completeness, or usefulness of any information, apparatus, product, or process disclosed, or represents that its use would not infringe privately owned rights. Reference herein to any specific commercial product, process, or service by trade name, trademark, manufacturer, or otherwise does not necessarily constitute or imply its endorsement or recommendation by the EERC. 


\section{BARRIER ISSUES TO THE UTILIZATION OF BIOMASS}

\section{ABSTRACT}

The Energy \& Environmental Research Center (EERC) has completed a project to examine fundamental issues that could limit the use of biomass in small industrial steam/power systems in order to increase the future use of this valuable domestic resource. Specifically, the EERC attempted to elucidate the ash-related problems - grate clinkering and heat exchange surface fouling - associated with cofiring coal and biomass in grate-fired systems. Utilization of biomass in stoker boilers designed for coal can be a cause of concern for boiler operators. Boilers that were designed for low-volatile fuels with lower reactivities can experience problematic fouling when switched to higher-volatile and more reactive coal-biomass blends. Higher heat release rates at the grate can cause increased clinkering or slagging at the grate due to higher temperatures. Combustion and loss of volatile matter can start much earlier for biomass fuels compared to design fuel, vaporizing alkali and chlorides which then condense on rear walls and heat exchange tube banks in the convective pass of the stoker, causing noticeable increases in fouling. In addition, stoker-fired boilers that switch to biomass blends may encounter new chemical species such as potassium sulfates, various chlorides, and phosphates. These species in combination with different flue gas temperatures, because of changes in fuel heating value, can adversely affect ash deposition behavior.

The goal of this project was to identify the primary ash mechanisms related to grate clinkering and heat exchange surface fouling associated with cofiring coal and biomass-specifically wood and agricultural residuals - in grate-fired systems, leading to future mitigation of these problems. The specific technical objectives of the project were:

- Modification of an existing pilot-scale combustion system to simulate a grate-fired system.

- Verification testing of the simulator.

- Laboratory-scale testing and fuel characterization to determine ash formation and potential fouling mechanisms and to optimize activities in the modified pilot-scale system.

- Pilot-scale testing in the grate-fired system. The resulting data were used to elucidate ashrelated problems during coal-biomass cofiring and offer a range of potential solutions.

This multitask project began in October 2000 and was completed with the preparation of this final technical report. This report documents project activities and summarizes results on a task basis. The focus of the discussion concerns Task 2 - Modification of the Pilot-Scale Combustion System; Task 4 - Laboratory-Scale Testing and Fuel Characterization; and Task 5 - Pilot-Scale Testing and Reporting. Task 2 involved modification of an existing pilot-scale pulverized coal-fired combustion system to permit its use in a grate-fired configuration without preventing its continued use in a pulverized fuel-firing configuration. Shakedown testing of the pilot-scale grate-fired simulator was completed to ensure the modified system (fuel preparation and feed, combustor, and flue gas analyzers) operated as intended. Based on the shakedown tests, the grate was modified and water cooling was added to the grate area to minimize clinker formation.

Task 4 involved fuel characterization and laboratory-scale combustion testing of coal (Cordero Rojo subbituminous) and biomass (wood chips and sunflower hulls) parent fuels and coal-biomass 
blends (80-20 and 60-40 blends by weight) to define key combustion and ash behavior issues to monitor during pilot-scale combustion testing. The highest deposit growth rate was found for the parent coal fired without biomass. This deposit, however, had the lowest strength of any of the deposits generated. The highest-strength deposit was observed for the 60-40 coal-sunflower hull blend, which also had the lowest growth rate.

Analysis of the 60-40 coal-sunflower hull blend deposit showed a potassiumcalcium-aluminosilicate bonding matrix essentially "gluing" the deposit together. The high concentration of potassium in the sunflower hulls, reacted with the abundant calcium aluminosilicates derived from the coal, led to lower-melting-point phases of lower viscosity, which tend to increase strength development in ash deposits. Analysis of the 60-40 coal-wood chip blend deposit showed a calcium-iron-aluminosilicate bonding matrix with iron crystallizing out of the melt. The crystallization of the iron can decrease the strength of the melt by creating areas that fracture more readily. The low ash content of the wood chips also contributed to a lower ash deposition rate and strength.

Based on the results of the laboratory-scale work, two coal-biomass cofiring tests were completed for Task 5 using the pilot-scale grate-fired system. The primary fuel was Cordero Rojo subbituminous coal. Each of the two biomass fuels, wood chips and sunflower hulls, were fired at nominally $40 \mathrm{wt} \%$ based on the laboratory-scale combustion test results. Overall, the pilot-scale stoker-fired system was shown to work well with respect to achieving desired combustion conditions. Minor problems were noted with biomass fuel feed and clinker formation. Both of these problems were overcome using manual mitigation techniques at regular intervals.

Ash deposition on convective surfaces was minimal for all tests, baseline coal as well as the coal-biomass cofiring tests. Only a few grams of ash were sticking to the ash deposition probe, and the material was mostly calcium and potassium sulfates. The resulting deposition observed would not significantly reduce the capability of a boiler to produce steam. Deposition characteristics indicated that the high calcium in the coal-wood blend and the high potassium in the coal-sunflower hull blend could create some lower-viscosity bonding material, but in this pilot-scale stoker-fired system there was little evidence of problematic ash deposition.

Furnace exit gas temperatures during the pilot-scale tests ranged from $1021^{\circ}$ to $1065^{\circ} \mathrm{C}\left(1870^{\circ}\right.$ to $\left.1948^{\circ} \mathrm{F}\right)$. Slightly higher $\left(56^{\circ} \mathrm{C}\left[100^{\circ} \mathrm{F}\right]\right)$ furnace exit gas temperatures could trigger more severe fouling. Also, the quantity of fly ash generated during these tests was lower than considered typical for stoker-fired applications. Therefore, these observations may have been influenced by grate clinker formation. 


\section{TABLE OF CONTENTS}

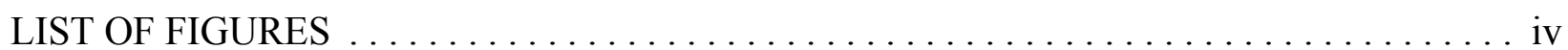

LIST OF TABLES $\ldots \ldots \ldots \ldots \ldots \ldots \ldots \ldots \ldots \ldots \ldots \ldots \ldots \ldots \ldots \ldots \ldots \ldots \ldots \ldots \ldots \ldots$

ACRONYMS, ABBREVIATIONS, AND UNITS $\ldots \ldots \ldots \ldots \ldots \ldots \ldots \ldots \ldots \ldots \ldots$ viii

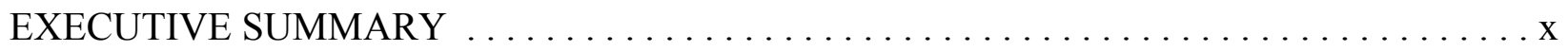

$1.0 \quad$ INTRODUCTION $\ldots \ldots \ldots \ldots \ldots \ldots \ldots \ldots \ldots \ldots \ldots \ldots \ldots \ldots \ldots \ldots \ldots$

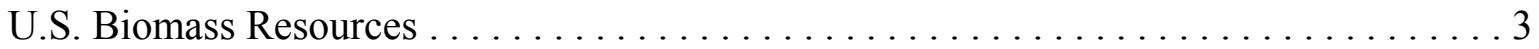

Technical Issues of Biomass Combustion $\ldots \ldots \ldots \ldots \ldots \ldots \ldots \ldots \ldots \ldots \ldots \ldots \ldots \ldots \ldots$

Biomass Power Systems . . . . . . . . . . . . . . . . . . . 7

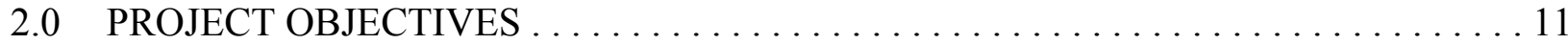

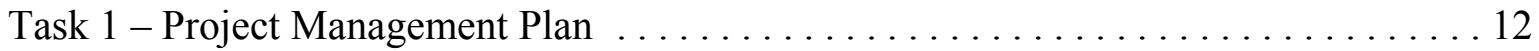

Task 2 - Modification of the Pilot-Scale Combustion System $\ldots \ldots \ldots \ldots \ldots \ldots \ldots$

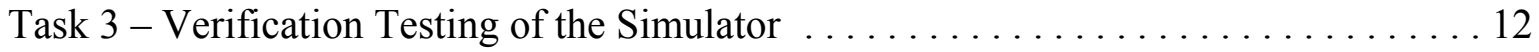

Task 4 - Laboratory-Scale Testing and Fuel Characterization $\ldots \ldots \ldots \ldots \ldots \ldots \ldots 12$

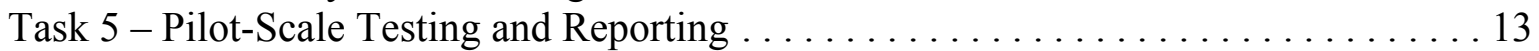

3.0 TECHNICAL/EXPERIMENTAL APPROACH $\ldots \ldots \ldots \ldots \ldots \ldots \ldots \ldots \ldots \ldots \ldots$

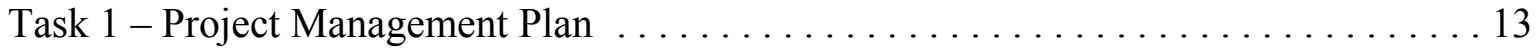

Task 2 - Modification of Pilot-Scale Combustion System .................... 14

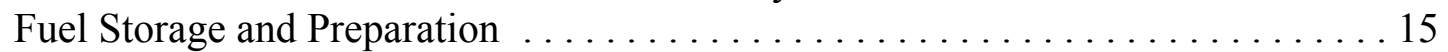

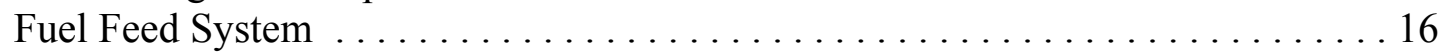

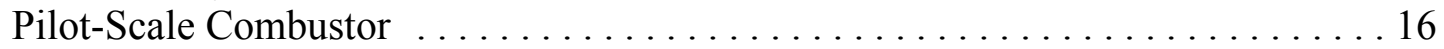

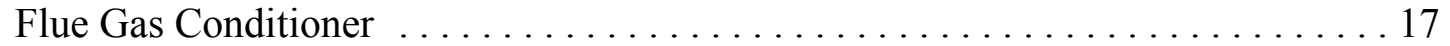

Flue Gas Analyzers ................................. 17

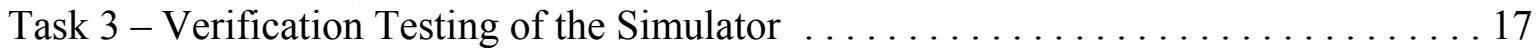

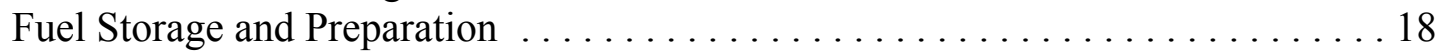

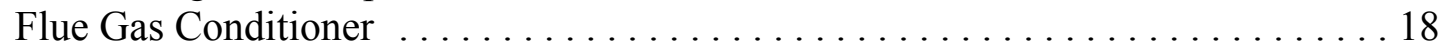

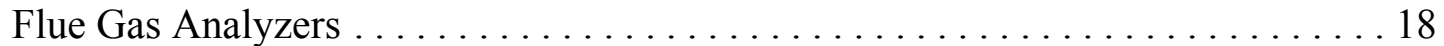

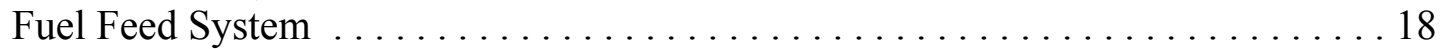

Pilot-Scale Combustor . ................................ 19

Task 4 - Laboratory-Scale Testing and Fuel Characterization $\ldots \ldots \ldots \ldots \ldots \ldots$

Fuel Selection .................................... 20

Biomass Fuel ................................... 21

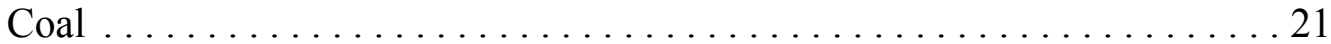

Low-Rank Coal (including PRB and North Dakota Beulah lignite) $\ldots \ldots 22$

Illinois No. 6 or No. 5 Bituminous Coal . . . . . . . . . . . . . . 22

Western Kentucky No. 9 Bituminous Coal . . . . . . . . . . . . . . . 22

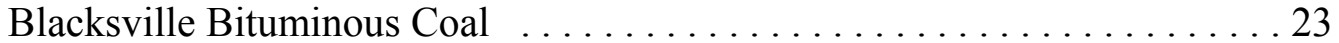

Continued ... 


\section{TABLE OF CONTENTS (continued)}

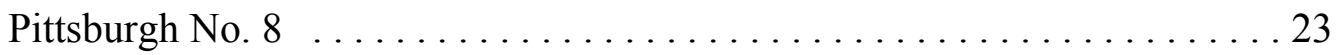

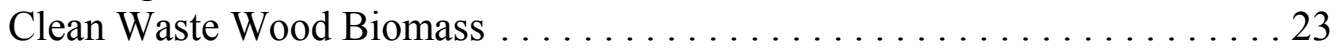

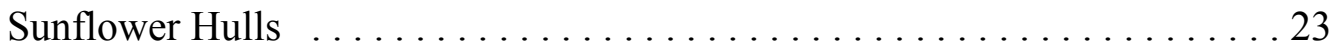

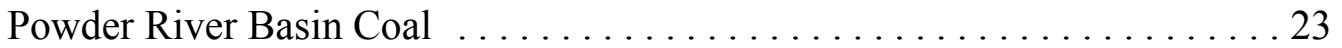

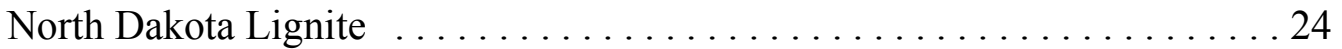

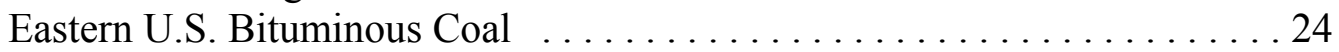

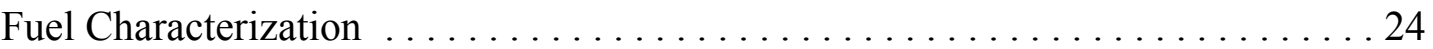

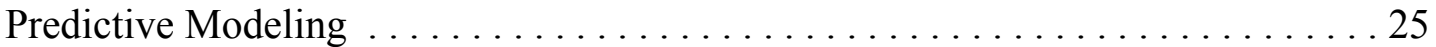

Laboratory-Scale Combustion Tests .......................... 25

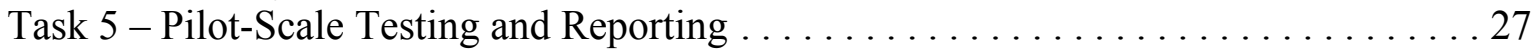

Pilot-Scale Combustion Tests . . . . . . . . . . . . . . . . . . . . . . . 27

Project Reporting Requirements .......................... 28

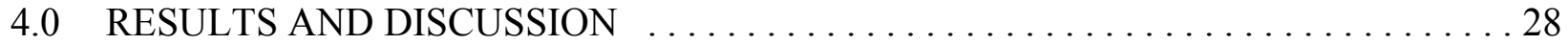

Task 2 - Modification of the Pilot-Scale Combustion System . . . . . . . . . . . . . 28

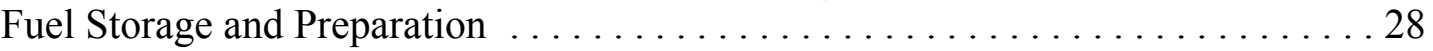

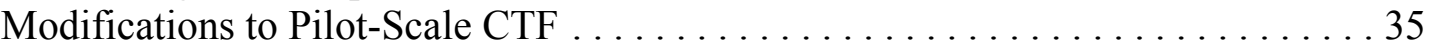

Flue Gas Instrumentation and Data Acquisition System Upgrades ........... 38

Task 3 - Verification Testing of the Simulator . . . . . . . . . . . . . . . . . 40

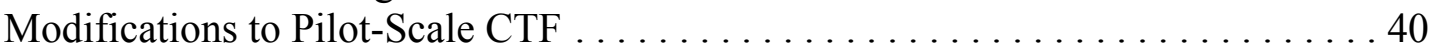

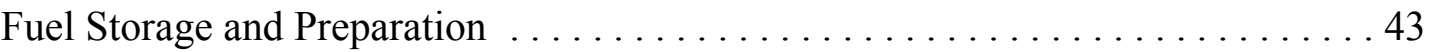

Flue Gas Instrumentation and Data Acquisition System Upgrades . . . . . . . . . 44

Task 4 - Laboratory-Scale Testing and Fuel Characterization . . . . . . . . . . . . . . 45

Characterization of Parent Fuels . . . . . . . . . . . . . . . . . . . . . . . . 45

Morphology Pictures of Parent Fuels . . . . . . . . . . . . . . . . . . . . . . . . . 49

Combustion Testing ................................... 49

Characterization of Deposit Ash .............................. 50

Emissions Analysis ......................................6 60

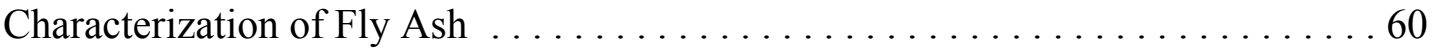

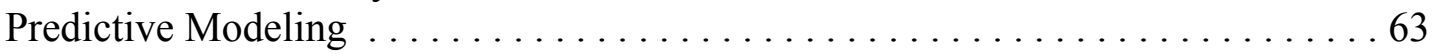

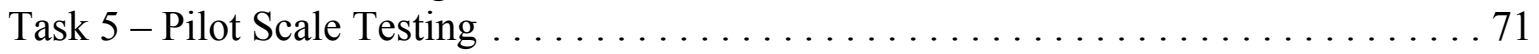

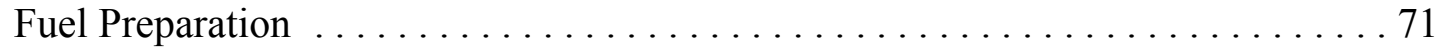

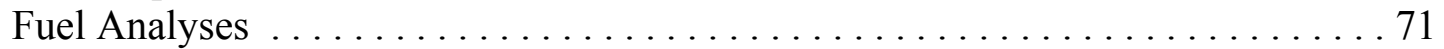

Standard ASTM Analyses ........................... 71

Advanced Fuel Analyses . . . . . . . . . . . . . . . . . . . . . . . . 73

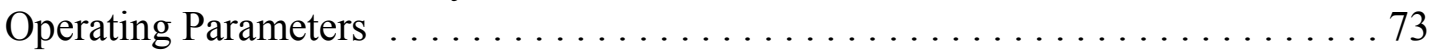

Ash Deposit Formation ................................... 79

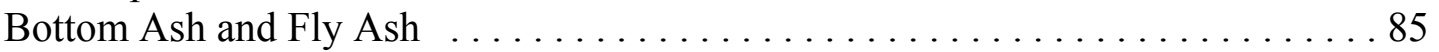

5.0 CONCLUSIONS AND RECOMMENDATIONS $\ldots \ldots \ldots \ldots \ldots \ldots \ldots \ldots$

Task 2 - Modification of Pilot-Scale Combustion System $\ldots \ldots \ldots \ldots \ldots \ldots \ldots$

Task 3 - Verification Testing of the Simulator ........................ 89

Continued ... 


\section{TABLE OF CONTENTS (continued)}

Task 4 - Laboratory-Scale Testing and Fuel Characterization $\ldots \ldots \ldots \ldots \ldots \ldots$

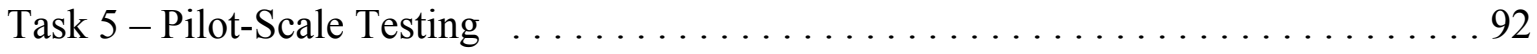

6.0 REFERENCES . . . . . . . . . . . . . . . . . . . . . . . . . . . . . . . 94

DESCRIPTION OF THE CEPS $\ldots \ldots \ldots \ldots \ldots \ldots \ldots \ldots \ldots \ldots \ldots \ldots \ldots \ldots \ldots \ldots \ldots \ldots \ldots \ldots$ Appendix A

FACT MODELING RESULTS $\ldots \ldots \ldots \ldots \ldots \ldots \ldots \ldots \ldots \ldots \ldots \ldots \ldots \ldots \ldots \ldots \ldots \ldots \ldots$ Appendix B 


\section{LIST OF FIGURES}

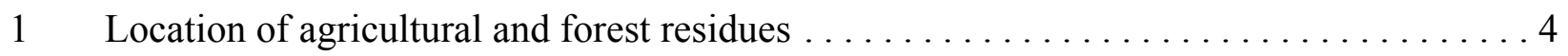

2 Promising locations for biomass energy crops $\ldots \ldots \ldots \ldots \ldots \ldots \ldots \ldots \ldots$

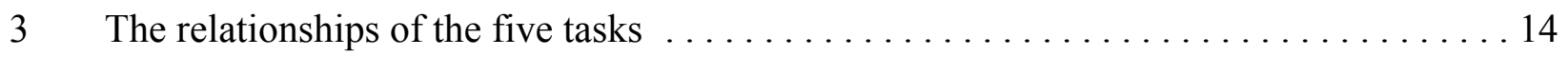

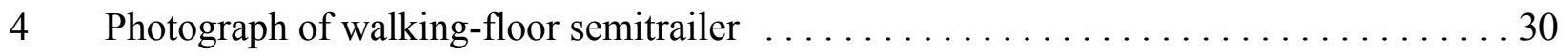

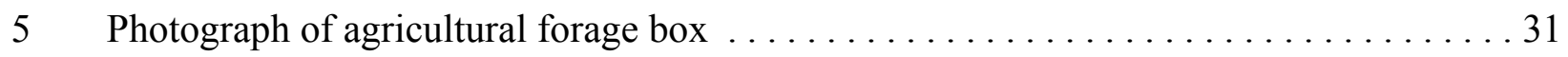

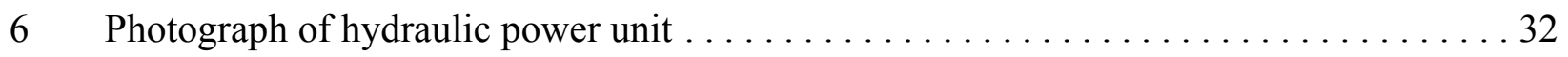

$7 \quad$ Photographs of hammer mill, blower assembly, and product recovery cyclone . . . . . 34

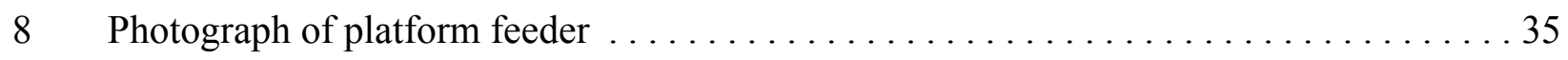

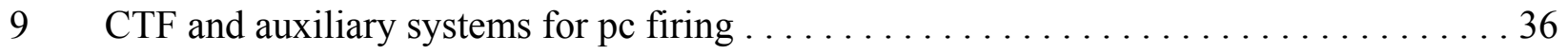

10 Illustration of components for grate-fired system $\ldots \ldots \ldots \ldots \ldots \ldots \ldots \ldots \ldots \ldots \ldots \ldots \ldots$

11 Photograph of grate-fired section added to CTF $\ldots \ldots \ldots \ldots \ldots \ldots \ldots \ldots \ldots \ldots$

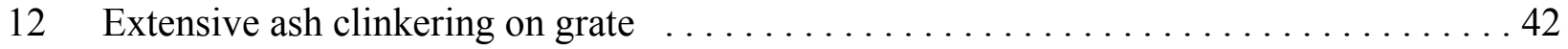

13 Bottom ash recovered after subsequent grate-fired test $\ldots \ldots \ldots \ldots \ldots \ldots \ldots 43$

14 Summary of bulk viscosities based on XRF analysis $\ldots \ldots \ldots \ldots \ldots \ldots \ldots$

15a Image of fouling deposit for $100 \%$ Cordero Rojo coal $\ldots \ldots \ldots \ldots \ldots \ldots \ldots$

15b Image of fouling deposit for $80 \%$ Cordero Rojo-20\% sunflower hull blend $\ldots \ldots \ldots . .51$

$15 \mathrm{c}$ Image of fouling deposit for $60 \%$ Cordero Rojo- $40 \%$ sunflower hull blend $\ldots \ldots \ldots 51$

15d Image of fouling deposit for $80 \%$ Cordero Rojo coal-20\% wood chip blend . . . . . . 52

$15 \mathrm{e}$ Image of fouling deposit for $60 \%$ Cordero Rojo coal- $40 \%$ wood chip blend . . . . . . 52

16a SEM micrograph of $100 \%$ Cordero Rojo deposit ash $\ldots \ldots \ldots \ldots \ldots \ldots \ldots \ldots \ldots \ldots \ldots \ldots \ldots \ldots$

16b SEM micrograph of 80-20 Cordero Rojo-sunflower hull deposit ash . . . . . . . . 55

Continued... 


\section{LIST OF FIGURES (continued)}

16c SEM micrograph of $60-40$ Cordero Rojo-sunflower hull deposit ash $\ldots \ldots \ldots \ldots \ldots 6$

16d SEM micrograph of $80-20$ Cordero Rojo-wood chip deposit ash $\ldots \ldots \ldots \ldots \ldots 56$

16e SEM micrograph of 60-40 Cordero Rojo-wood chip deposit ash $\ldots \ldots \ldots \ldots \ldots 57$

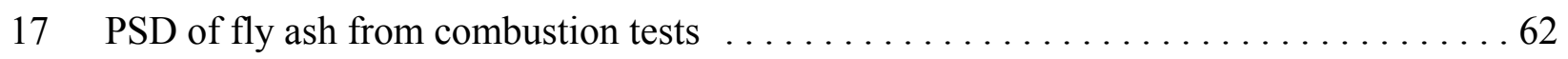

18 Cumulative submicron combustion ash PSD for coal and coal-sunflower hull blends . . 64

19 Cumulative submicron combustion ash PSD for coal and coal-wood blends . . . . . . . 64

20a SEM micrograph of $100 \%$ Cordero Rojo fly ash $\ldots \ldots \ldots \ldots \ldots \ldots \ldots \ldots \ldots \ldots \ldots \ldots \ldots \ldots$

20b SEM micrograph of $80-20$ Cordero Rojo-sunflower hull fly ash $\ldots \ldots \ldots \ldots \ldots \ldots 6$

20c SEM micrograph of 60-40 Cordero Rojo-sunflower hull fly ash . . . . . . . . . . . 66

20d SEM micrograph of 80-20 Cordero Rojo-wood chip fly ash $\ldots \ldots \ldots \ldots \ldots \ldots \ldots 6$

20e SEM micrograph of 60-40 Cordero Rojo-wood chip fly ash $\ldots \ldots \ldots \ldots \ldots \ldots$

21 Photograph of fouling probe bank - AF-CTS-Stoker01 - baseline Cordero Rojo . . . . 80

22 Photograph of fouling probe bank - AF-CTS-Stoker02 - 60-40 Cordero Rojo-

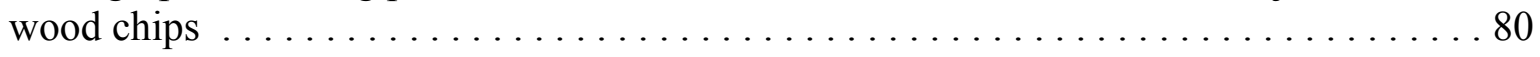

23 Photograph of fouling probe bank - AF-CTS-Stoker03 - 60-40 Cordero Rojo-

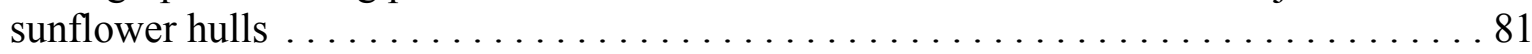

24 Cordero Rojo deposit in $\mathrm{CTF}-\mathrm{pc}$ fired $-1204^{\circ} \mathrm{C}\left(2200^{\circ} \mathrm{F}\right) \ldots \ldots \ldots \ldots \ldots \ldots$

25 Fly ash-size distribution by Malvern analysis - baseline Cordero Rojo $\ldots \ldots \ldots \ldots 86$

26 Fly ash-size distribution by Malvern analysis - 60-40 Cordero Rojo-wood chips . . . 87

27 Fly ash-size distribution by Malvern analysis - 60-40 Cordero Rojo-sunflower hulls . 87 


\section{LIST OF TABLES}

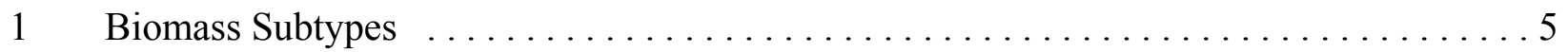

2 Fuel Characteristics Requiring Special Attention $\ldots \ldots \ldots \ldots \ldots \ldots \ldots \ldots \ldots$

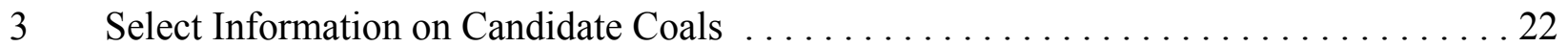

4 Proximate and Ultimate Analysis of Fuels $\ldots \ldots \ldots \ldots \ldots \ldots \ldots \ldots \ldots \ldots$

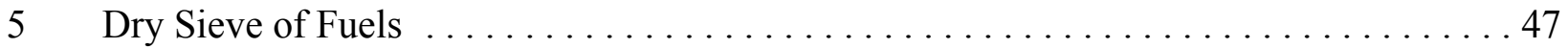

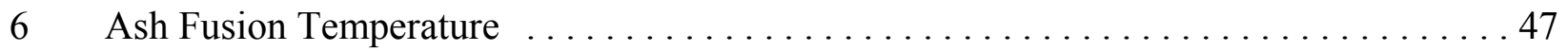

$7 \quad$ Ash Fusion Cone Analysis Before and After Analysis $\ldots \ldots \ldots \ldots \ldots \ldots \ldots$

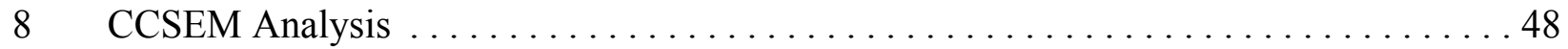

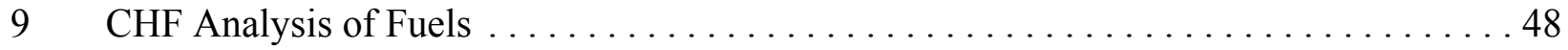

10 Growth Rate of Deposits, Crushing Strength, and Sticking Fraction $\ldots \ldots \ldots \ldots \ldots 3$

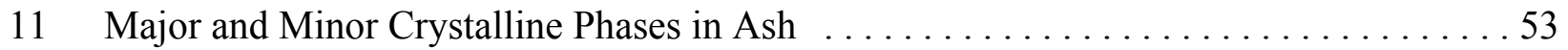

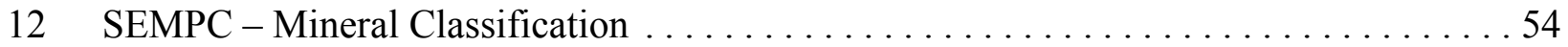

13a $100 \%$ Cordero Rojo Deposit Ash Morphology Analysis Results . ............. 57

13b 80-20 Cordero Rojo-Sunflower Hull Deposit Ash Morphology Analysis Results . . . . 58

13c 60-40 Cordero Rojo-Sunflower Hull Deposit Ash Morphology Analysis Results . . . 58

13d 80-20 Cordero Rojo-Wood Chip Deposit Ash Morphology Analysis Results . . . . . . . 59

13e 60-40 Cordero Rojo-Wood Chip Deposit Ash Morphology Analysis Results . . . . . . . 59

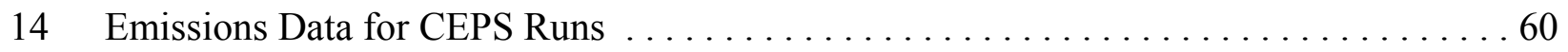

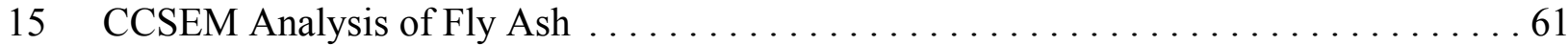

16 Elemental Composition of Unclassified Content .......................61 61

17a $100 \%$ Cordero Rojo Fly Ash Morphology Analysis Results ................ 67

Continued... 


\section{LIST OF TABLES (continued)}

17b 80-20 Cordero Rojo-Sunflower Hull Fly Ash Morphology Analysis Results . . . . . . 68

17c 60-40 Cordero Rojo-Sunflower Hull Fly Ash Morphology Analysis Results . . . . . . 68

17d 80-20 Cordero Rojo-Wood Chip Fly Ash Morphology Analysis Results . . . . . . . . 69

17e 60-40 Cordero Rojo-Wood Chip Fly Ash Morphology Analysis Results . . . . . . . 69

18 Index Calculations from PCQUEST Model $\ldots \ldots \ldots \ldots \ldots \ldots \ldots \ldots$

19 Relative Severity of Fouling at Furnace Exit Temperature of $1500^{\circ} \mathrm{C}\left(2732^{\circ} \mathrm{F}\right) \ldots \ldots 70$

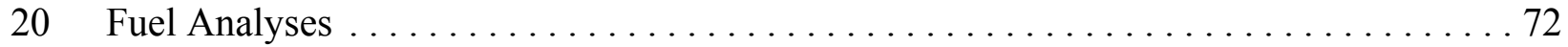

21 CHF Results $\ldots \ldots \ldots \ldots \ldots \ldots \ldots \ldots \ldots \ldots \ldots \ldots \ldots \ldots \ldots \ldots \ldots$

22 CCSEM Results - Cordero Rojo Coal $\ldots \ldots \ldots \ldots \ldots \ldots \ldots \ldots \ldots \ldots \ldots$

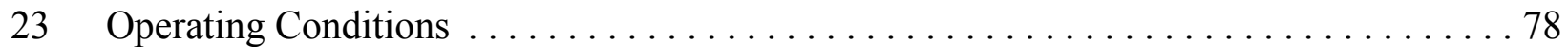

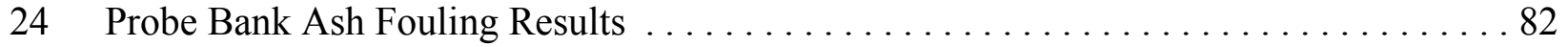

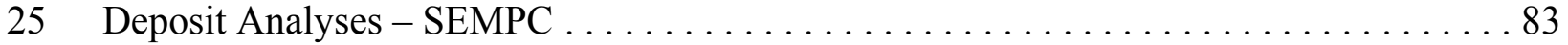

26 X-Ray Diffraction Analyses of Sinter Deposits . . . . . . . . . . . . . . . . . 84

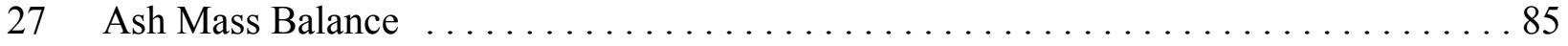

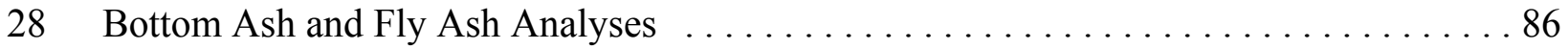




\section{ACRONYMS, ABBREVIATIONS, AND UNITS}

\begin{tabular}{|c|c|}
\hline acfm & actual cubic feet per minute \\
\hline acmm & actual cubic meters per minute \\
\hline $\mathrm{Al}_{2} \mathrm{O}_{3}$ & alumina (aluminum oxide) \\
\hline APS & aerodynamic particle sizer \\
\hline BSE & backscattered electron image \\
\hline Btu & British thermal unit \\
\hline${ }^{\circ} \mathrm{C}$ & degrees Celsius \\
\hline $\mathrm{CaO}$ & calcium oxide \\
\hline CCSEM & computer-controlled scanning electron microscopy \\
\hline CEPS & conversion and environmental process simulator \\
\hline $\mathrm{CHF}$ & chemical fractionation \\
\hline $\mathrm{cm}$ & centimeter \\
\hline $\mathrm{CO}$ & carbon monoxide \\
\hline COR & Contracting Officer's Representative \\
\hline $\mathrm{CO}_{2}$ & carbon dioxide \\
\hline CTF & combustion test facility \\
\hline DOE & U.S. Department of Energy \\
\hline $\mathrm{ECN}$ & $\begin{array}{l}\text { Energieonderzoek Centrum Nederland (Netherlands Energy Research } \\
\text { Foundation) }\end{array}$ \\
\hline EDX & energy-dispersive $\mathrm{x}$-ray \\
\hline EERC & Energy \& Environmental Research Center \\
\hline EPA & U.S. Environmental Protection Agency \\
\hline ESP & electrostatic precipitator \\
\hline EU & European Union \\
\hline${ }^{\circ} \mathrm{F}$ & degrees Fahrenheit \\
\hline FACT & Facility for the Analysis of Chemical Thermodynamics \\
\hline FD & forced draft \\
\hline FEGT & furnace exit gas temperature \\
\hline $\mathrm{Fe}_{2} \mathrm{O}_{3}$ & iron(III) oxide \\
\hline FI & fouling index \\
\hline $\mathrm{ft}$ & feet \\
\hline $\mathrm{ft}^{2}$ & feet squared \\
\hline $\mathrm{ft}^{3}$ & feet cubed \\
\hline g & gram \\
\hline GJ & gigajoule \\
\hline $\mathrm{HCl}$ & hydrochloric acid \\
\hline hp & horsepower \\
\hline $\mathrm{hr}$ & hour \\
\hline ID & induced draft \\
\hline in. & inch \\
\hline $\mathrm{K}_{2} \mathrm{O}$ & potassium oxide \\
\hline $\mathrm{kg}$ & kilogram \\
\hline $\mathrm{kJ}$ & kilojoule \\
\hline kW & kilowatt \\
\hline
\end{tabular}




\begin{tabular}{|c|c|}
\hline $\begin{array}{l}\mathrm{kWh} \\
\mathrm{lb}\end{array}$ & $\begin{array}{l}\text { kilowatt-hour } \\
\text { pound }\end{array}$ \\
\hline $\begin{array}{l}10 \\
\mathrm{~m}\end{array}$ & $\begin{array}{l}\text { pound } \\
\text { meter }\end{array}$ \\
\hline M & molar \\
\hline $\mathrm{m}^{2}$ & meter squared \\
\hline $\mathrm{m}^{3}$ & meter cubed \\
\hline $\mathrm{MgO}$ & magnesium oxide \\
\hline $\min$ & minute \\
\hline MJ & megajoule \\
\hline MMBtu & million $\left(10^{6}\right)$ British thermal units \\
\hline $\mathrm{mm}$ & millimeter \\
\hline MSW & municipal solid waste \\
\hline MW & megawatt \\
\hline $\mathrm{Na}_{2} \mathrm{O}$ & sodium oxide \\
\hline NETL & National Energy Technology Laboratory \\
\hline $\mathrm{NO}_{\mathrm{x}}$ & nitrogen oxides (nitric oxide and nitrogen dioxide) \\
\hline $\mathrm{O}_{2}{ }^{\wedge}$ & oxygen \\
\hline $\mathrm{OPC}$ & object linking and embedding for process control \\
\hline pc & pulverized coal \\
\hline $\begin{array}{l}\text { PCQUEST } \\
\mathrm{P}_{2} \mathrm{O}_{5}\end{array}$ & $\begin{array}{l}\text { Predictive Coal Quality Effects Screening Tool } \\
\text { phosphorus pentoxide }\end{array}$ \\
\hline ppm & parts per million \\
\hline $\mathrm{PJ}$ & pectajoule \\
\hline PRB & Powder River Basin \\
\hline PSD & particle-size distribution \\
\hline psi & pounds per square inch \\
\hline $\mathrm{RDF}$ & refuse-derived fuel \\
\hline RTI & Research Triangle Institute \\
\hline s & second \\
\hline SEM & scanning electron microscopy \\
\hline SEMPC & scanning electron microscopy point count \\
\hline $\mathrm{SiO}_{2}$ & silica (silicon dioxide) \\
\hline SMPS & scanning mobility particle sizer \\
\hline $\mathrm{SO}_{2}$ & sulfur dioxide \\
\hline $\mathrm{TiO}_{2}$ & titanium oxide \\
\hline TVÁ & Tennessee Valley Authority \\
\hline $\mathrm{wt} \%$ & weight percent \\
\hline XRD & $\mathrm{x}$-ray diffraction \\
\hline XRF & $\mathrm{x}$-ray fluorescence \\
\hline$\mu \mathrm{m}$ & micron \\
\hline UND & University of North Dakota \\
\hline V & volt \\
\hline
\end{tabular}




\section{BARRIER ISSUES TO THE UTILIZATION OF BIOMASS}

\section{EXECUTIVE SUMMARY}

\section{Introduction}

The Energy \& Environmental Research Center (EERC) has completed a project to examine fundamental issues that could limit the use of biomass in small industrial steam-power systems in order to increase the future use of this valuable domestic resource. Specifically, the EERC attempted to elucidate the ash-related problems-grate clinkering and heat exchange surface fouling - associated with cofiring coal and biomass in grate-fired systems. Utilization of biomass in stoker boilers designed for coal can be a cause of concern for boiler operators. Boilers that were designed for low-volatile fuels with lower reactivities can experience problematic fouling when switched to higher-volatile and more reactive biomass-coal blends. Higher heat release rates at the grate can cause increased clinkering or slagging at the grate due to higher temperatures. Combustion and loss of volatile matter can start much earlier for biomass fuels compared to design fuel, vaporizing alkali and chlorides which then condense on rear walls and heat exchange tube banks in the convective pass of the stoker, causing noticeable increases in fouling. In addition, stoker-fired boilers that switch to biomass blends may encounter new chemical species such as potassium sulfates, various chlorides, and phosphates. These species in combination with different flue gas temperatures, because of changes in fuel heating value, can adversely affect ash deposition behavior.

The goal of this multitask project was to identify the primary ash mechanisms related to grate clinkering and heat exchange surface fouling associated with cofiring coal and biomass - specifically a wood and agricultural residual — in grate-fired systems, leading to future mitigation of these problems. The specific technical objectives of the project were:

- Modification of an existing EERC pilot-scale combustion system to simulate a grate-fired system and verification testing of the simulator.

- Laboratory-scale testing and fuel characterization to determine ash formation and potential fouling mechanisms and to optimize activities in the modified pilot-scale system.

- Pilot-scale testing in the grate-fired system. The resulting data were used to elucidate ashrelated problems during coal-biomass cofiring and offer a range of potential solutions.

\section{Task 1 - Project Management Plan}

Task 1 was initiated in October 2000 and involved the preparation of a detailed Project Plan, Milestone Plan, and Milestone Log for review and approval by the U.S. Department of Energy (DOE). A Hazardous Substance Plan was also required. A Project Plan, Milestone Plan, and Milestone Log were prepared and submitted to DOE on November 29, 2000. In December 2000, the Contracting Officer's Representative (COR) approved Task 2 - Modification of the Pilot-Scale Combustion System activities as detailed in the Project Plan. However, the COR requested further discussion of fuel selection, fuel selection rationale, and the scope of work planned for Task 4 Laboratory-Scale Testing and Fuel Characterizations prior to authorizing the EERC to proceed. As 
a result of subsequent discussions and preparation of a revised Project Plan, the entire Project Plan was approved in February 2001.

\section{Task 2 - Modification of the Pilot-Scale Combustion System}

The overall objective of Task 2 was to upgrade EERC capabilities as they pertain to the performance of pilot-scale combustion tests involving the firing of biomass or coal-biomass blends. The EERC currently has several pilot-scale systems to simulate pulverized coal (pc) and fluid-bed combustion firing. These systems have been used to study biomass and coal-biomass cofiring. A significant limitation of existing systems was that they did not effectively simulate grate firing, as is necessary to understand and identify opportunities to mitigate problems in full-scale stoker facilities. The EERC's combustion test facility (CTF) was modified to simulate a grate-fired system. However, the modifications made will not prevent future operation of the pilot-scale combustion system in an entrained firing configuration. The CTF is an up-fired reactor (approximately $70 \mathrm{lb}$ coal $/ \mathrm{hr}$ ) that contains an existing fouling probe bank to simulate convective surfaces and a particulate control system that permits the use of either an electrostatic precipitator or a pulse-jet fabric filter.

In addition to modifications directly to the CTF combustor, modifications were made to the feed system, and feed preparation and handling equipment were procured to facilitate preparation of fuels for the grate-fired system. Upgrades were also made to the flue gas instrumentation and data acquisition systems.

\section{Fuel Storage and Preparation}

The EERC has had storage, handling, and preparation equipment to effectively process and size coal for use in pilot-scale pc-fired systems as well as fluid-bed combustion systems and pilotscale gasification systems for $30+$ years. Selective use and minor adjustments to this equipment permitted the preparation of appropriately sized coal for use in a pilot-scale grate-fired system. However, capabilities were not adequate to store and process biomass. Therefore, the EERC evaluated options to address biomass storage and processing (drying and sizing) requirements in order to meet the needs of this project as well as anticipated future projects involving biomass. As a result, the EERC procured and installed new and used equipment items to meet biomass storage and processing requirements.

Existing storage bunkers at the EERC were not appropriate for use with most biomass fuels because they were designed for coal. Because biomass has significantly different flow properties and bulk density, alternative storage options were reviewed. The primary option that the EERC considered was the acquisition of a used over-the-road transport trailer that could be adequately tarped with a "live" bottom discharge. An over-the-road trailer could be used to pick up a quantity of biomass at a commercial site as well as meet on-site storage requirements.

As a result of conversations with U.S. Environmental Protection Agency (EPA) personnel, the EERC found a used walking-floor semitrailer being offered by the Research Triangle Institute (RTI). The trailer is a 1979 Budd walking-floor trailer (12-m, or 40-ft, tractor trailer) and had been used in support of an EPA biomass demonstration project. The gross load limit for the trailer is 30,900 $\mathrm{kg}$ (34 tons), with a net cargo weight limit of $21,800 \mathrm{~kg}$ (24 tons). Nominal capacity on a volumetric 
basis is $72 \mathrm{~m}^{3}\left(2560 \mathrm{ft}^{3}\right)$. Assuming a material bulk density of $240 \mathrm{~kg} / \mathrm{m}^{3}\left(15 \mathrm{lb} / \mathrm{ft}^{3}\right)$, the capacity of the trailer would be nominally $17,000 \mathrm{~kg}(38,000 \mathrm{lb}$, or 19 tons). After several conversations with RTI and EPA personnel concerning the condition of the trailer and options for relocating it from North Carolina to North Dakota, the EERC initiated procurement actions in order to obtain the used walking-floor semitrailer. Subsequent to its delivery, the EERC had a new roll tarp installed on the trailer to protect its contents from weather conditions.

In addition to the walking-floor semitrailer, the EERC also elected to purchase an agricultural forage box. The forage box will be used for storage of small quantities of biomass fuel. However, its primary use will be to transfer biomass fuel from storage to processing equipment. After reviewing new and used forage box options, the EERC elected to purchase a front-rear combination unload Badger forage box with a net weight limit of $8200 \mathrm{~kg}$ (9 tons). Nominal capacity on a volumetric basis is $23 \mathrm{~m}^{3}\left(800 \mathrm{ft}^{3}\right)$. Assuming a material bulk density of $240 \mathrm{~kg} / \mathrm{m}^{3}\left(15 \mathrm{lb} / \mathrm{ft}^{3}\right)$, the capacity of the trailer would be nominally $5450 \mathrm{~kg}(12,000 \mathrm{lb}$, or 6 tons). The combination front-rear unload capability permits the EERC to select between a controlled discharge of forage box contents through the front cross conveyor or unloading of the entire contents of the forage box in a short period of time through the rear door. The versatility offered by this arrangement is highly desirable when considering potential material-handling and processing requirements.

Fuel preparation had to address two potential requirements: 1) the need to dry a given quantity of biomass and 2) the need to properly size the biomass for a given combustion or gasification system. The need to dry a given biomass in support of this project was a low priority. However, options were considered where a surface moisture-drying capability could be incorporated into the general biomass storage or transfer capabilities.

Proper fuel sizing at reasonable capacity was the highest priority with respect to fuel preparation. Therefore, the EERC's primary objective for acquisition of fuel-sizing equipment addressed adequate capacity ( 227 to $454 \mathrm{~kg} / \mathrm{hr}$, or 500 to $1000 \mathrm{lb} / \mathrm{hr}$ ) and size reduction capabilities to specifically match fuel size requirements for pilot-scale combustion and gasification systems. As a result of discussions with several potential equipment suppliers, the EERC elected to focus on the acquisition of an appropriately sized hammer mill, with multiple screens to affect product size, to achieve most biomass fuel preparation requirements. After reviewing options concerning new and used equipment, the EERC elected to procure a rebuilt Jacobson hammer mill, Model 556DF11. This hammer mill is a quick-change half-screen unit with the capability to discharge product through an outlet blower or gravity chute. Depending on the feed material type and size and desired product size, processing capacity should be 454 to $908 \mathrm{~kg} / \mathrm{hr}$ (1000 to $2000 \mathrm{lb} / \mathrm{hr}$ ). Processing kiln-dried hardwood scraps into wood chips resulted in a product rate of $227 \mathrm{~kg} / \mathrm{hr}(500 \mathrm{lb} / \mathrm{hr})$. Straw/grasstype biomass was also processed in the hammer mill, but the small quantity of material processed did not lend itself to determination of a product mass rate. Softwood and straw/grass-type biomass should result in a product rate of at least $454 \mathrm{~kg} / \mathrm{hr}(1000 \mathrm{lb} / \mathrm{hr})$.

\section{Modifications to Pilot-Scale CTF}

Modifications to the CTF were necessary in order to facilitate its operation in a grate-fired configuration while maintaining its pc-firing capability. The CTF was selected for this modification because of an extensive existing ash deposition database resulting from the pc-firing of bituminous and subbituminous coal, lignite, petcoke, biomass fuels, and various fuel blends over the past 
$40+$ years. As a result of the modifications made to facilitate grate firing, the only changes made involved fabricating a new bottom section for the combustor, combustion air piping, and the addition of a separate fuel feed system for grate firing. An illustration and photograph of the grate-fired section added to the pilot-scale combustion system are presented in Figures ES-1 and ES-2.

Specific design work was related to grate geometry, properly sizing the grate area to match the firing rate of the combustion system, combustion air distribution, and fuel feed options relative to grate geometry and size. The final design resulted in a rectangular grate with a surface area of $0.12 \mathrm{~m}^{2}$, or $1.25 \mathrm{ft}^{2}(25 \times 46 \mathrm{~cm}$, or $10 \mathrm{in} . \times 18 \mathrm{in}$. $)$ in order to match the grate size to the combustion system firing rate (nominally $0.58 \mathrm{~kJ} / \mathrm{hr}$, or $0.55 \mathrm{MMBtu} / \mathrm{hr}$ ). The resulting grate area on a firing rate basis is $0.21 \mathrm{~m}^{2} / \mathrm{GJ}\left(2.27 \mathrm{ft}^{2} / \mathrm{MMBtu}\right)$. The grate is simply a $0.64-\mathrm{cm}(0.25-\mathrm{in}$.) 316 stainless steel plate. The grate open area is $3.43 \%$.

The fixed-grate arrangement required the use of a ram to periodically move fuel and ash across the grate. Ram actuation frequency and stroke length vary depending on the fuel properties, firing rate, and whether a single fuel is fired or fuel cofiring is required. The fuel feed system makes use of a gravity feed dual-hopper-gate arrangement that permits the distribution of fuel on the fixed grate to a desired level for a given fuel particle size and heating value. Changes in fuel feed rate are made using a combination of adjustments to the elevation of the fuel gates and the operating frequency and stroke length of the ram over the fixed grate.

Primary combustion airflow to the grate is controlled and divided into four zones over the length of the grate representing $18 \%, 30 \%, 28 \%$, and $24 \%$ of the grate area, respectively. Overfire air is injected through multiple opposing ports about $71 \mathrm{~cm}(28 \mathrm{in}$.) above the grate. Primary and

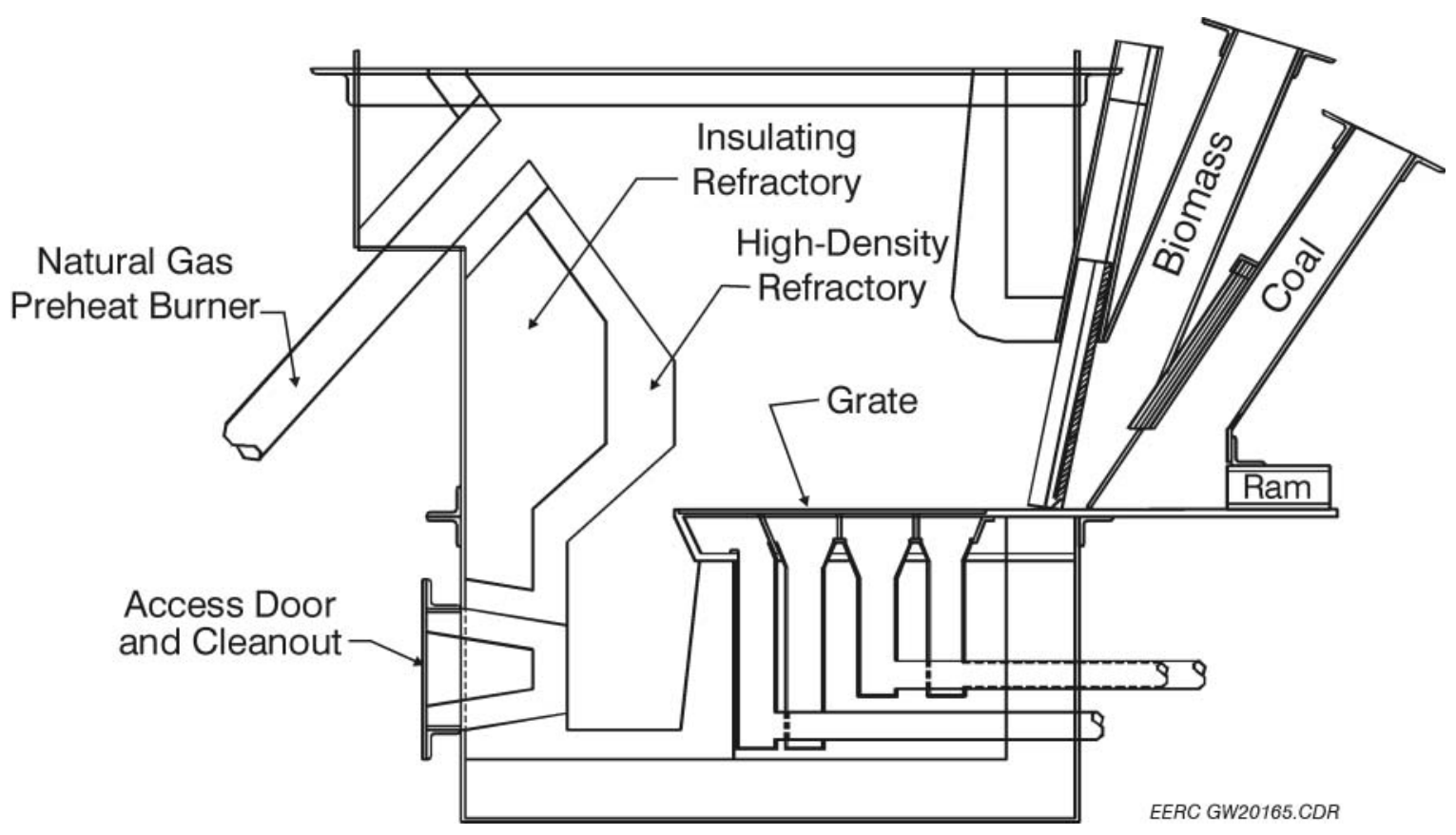

Figure ES-1. Illustration of components for the grate-fired system. 


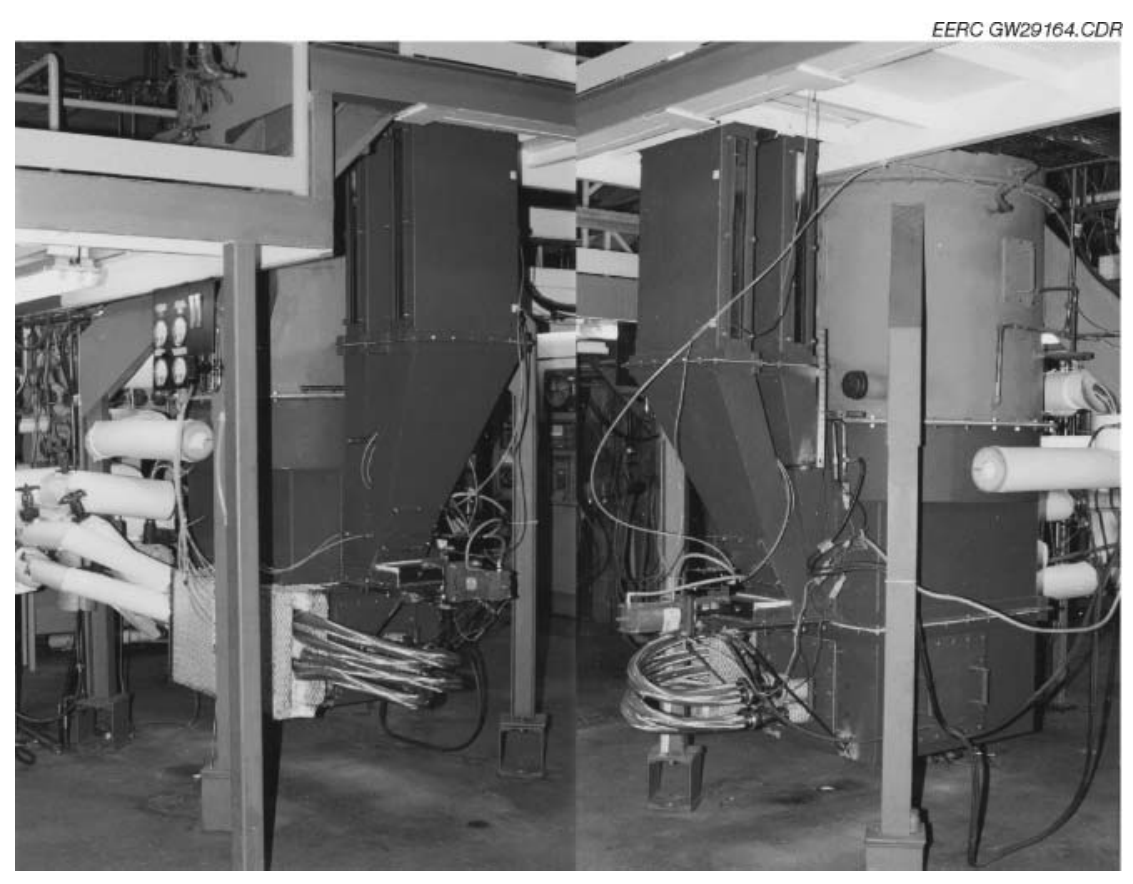

Figure ES-2. Photographs of the grate-fired section added to the CTF.

overfire air represent $80 \%-90 \%$ and $10 \%-20 \%$ of the total combustion air, respectively. The refractory-lined combustor is preheated firing natural gas prior to initiating solid fuel firing.

Initial shakedown tests resulted in excessive ash clinkering on the grate. EERC personnel felt that the ash clinkers initiated along the refractory walls adjacent to the grate and propagated across the grate surface. Modifications to minimize ash clinkering included fabricating a new grate, adding water-cooled surfaces to the refractory walls adjacent to the grate, and adding two additional sight ports to improve the ability to observe and access the grate on-line.

The new grate design increased the number of effective air nozzles but reduced the nozzle diameter in order to maintain the percent open grate area desired (3.43\%). Hole diameters decreased from $0.396 \mathrm{~cm}(0.156 \mathrm{in}$.) to $0.239 \mathrm{~cm}(0.094 \mathrm{in}$.), and the number of holes increased from 322 to 837. Hole spacing within each row is $1.572 \mathrm{~cm}(0.619 \mathrm{in}$.) on center, and row spacing is $0.785 \mathrm{~cm}$ ( 0.309 in.) on center. In addition, water-cooled tubing was added to the air plenum side of the grate to improve grate thermal protection. Once these modifications to the grate-fired system were completed, a shakedown test was performed to verify that the modifications made had successfully mitigated the ash clinkering previously observed.

\section{Flue Gas Instrumentation and Data Acquisition System Upgrades}

In addition to modifications directly to the pilot-scale CTF fuel feed system and combustor, upgrades were also made to the flue gas instrumentation and data acquisition system. Flue gas instrumentation upgrades included an electronic flue gas sample conditioner, a paramagnetic $\mathrm{O}_{2}$ analyzer, nondispersive infrared absorption spectrophotometers for the measurement of $\mathrm{CO}_{2}$ and $\mathrm{CO}$, a nondispersive ultraviolet absorption spectrophotometer for the measurement of $\mathrm{SO}_{2}$, and a 
chemiluminescence analyzer for the measurement of nitrogen species. All constituents are measured on a dry volume basis.

Upgrades to the data acquisition system included software as well as hardware. The suite of software procured is used for supervisory control of pilot-scale equipment. The software provides an interface to field data and hardware used to provide trending and alarming, data collection, and control operations.

\section{Task 3 - Verification Testing of the Simulator}

The primary objective of Task 3 was to shake down and verify the performance of the modified pilot-scale grate-fired combustion system prior to the performance of pilot-scale combustion tests in Task 5 . The pilot-scale grate-fired simulator was subjected to verification testing to ensure the modified system (fuel preparation and feed, combustor, and flue gas analyzers) operated as intended. Data evaluated included process temperatures and flow rates, grate ash properties, fly ash properties, and flue gas properties.

Initial shakedown tests were conducted using a subbituminous coal, the same coal used during Task 5 pilot-scale tests, with subsequent shakedown tests completed cofiring the subbituminous coal and wood chips. Results from the shakedown tests demonstrated that the fuel feed system worked as designed when feeding a single fuel such as the subbituminous coal. Coal was initially sized to $-2.5 \mathrm{~cm}(-1.0 \mathrm{in}$.) and $+0.64 \mathrm{~cm}(+0.25 \mathrm{in}$.). However, shakedown tests indicated that a smaller top size $(1.9 \mathrm{~cm}$, or $0.75 \mathrm{in}$.) improved pilot-scale grate-fired system performance. The improvement in performance with reduced coal top size is characteristic of the scale at which this project was conducted and not indicative of coal size requirements for commercial grate-fired systems. Fullscale grate-fired systems effectively use coal top-sized to $5 \mathrm{~cm} \mathrm{(2} \mathrm{in.)} \mathrm{and} \mathrm{larger.}$

When initially attempting to cofire wood chips, wood chip feed was inconsistent because of bridging in the fuel hopper. This problem was mitigated to a significant degree as a result of processing the wood chips through the hammer mill a second time to eliminate oversized material (wood chips having a length-to-diameter ratio of $>2$ ). For both the first and second passes through the hammer mill, the wood chips were processed using a $1.3-\mathrm{cm}(-0.5$-in.) screen. The same result could have been achieved using a classifier to recover the oversized material and then processing the oversized material through the hammer mill. For biomass cofiring at the pilot-scale level an alternative to the gravity based arrangement used in support of this project may be warranted. One option worth considering is a screw feed system that would deliver biomass fuel to the front of the grate. As with the coal, problems with oversized wood chips were more a characteristic of the scale at which this project was conducted and not indicative of fuel size requirements for commercial grate-fired systems. EERC experience with wood chip firing in an industrial grate-fired system indicates that a nominal 5-cm (2-in.) product from a hammer mill would be acceptable while limiting undersized material $(-0.64 \mathrm{~cm} /-0.25 \mathrm{in}$.) to avoid excessive fuel entrainment from the grate.

Subsequent pilot-scale tests cofiring sunflower hulls demonstrated that the sunflower hulls fed more consistently through the gravity-based feed system than the wood chips because of their more uniform size distribution and generally less angular shape. EERC experience evaluating sunflower hull firing in an industrial grate-fired system determined that sizing of the sunflower hulls was not 
necessary and the sunflower hulls could be blended and fed with the coal using existing equipment. However, some modification of overfire airflow rate and distribution would be appropriate in order to optimize cofiring sunflower hulls, and some equipment upgrades may be necessary to control fugitive dust when blending sunflower hull-type biomass with coal.

A modification to the ram also improved the performance of the pilot-scale fuel feed system. Specifically, the height of the ram was reduced from $7.6 \mathrm{~cm}$ (3.0 in.) to $3.8 \mathrm{~cm}$ (1.5 in.), reducing its cross-sectional area. This change resulted in an increased ram stroke frequency for a given fuel firing rate.

As previously stated, initial shakedown tests resulted in excessive ash clinkering on the grate. Although the modifications previously described did not eliminate ash clinkering on the grate, it was reduced to a point that permitted the successful completion of grate-fired tests. Bottom ash carbon content was 6-12 $\mathrm{wt} \%$ as a result of successfully completed grate-fired tests.

Further modifications to the pilot-scale grate-fired system in the future are likely to improve performance and increase flexibility. However, any modifications to the fuel feed system are likely to be fuel-specific. In addition, EERC personnel believe operational changes would also further reduce grate clinkering and result in other improvements in overall combustor performance. Some of these include reducing fuel particle size, reducing the thickness of the fuel bed on the grate, changes in primary and overfire air distribution, and changes to the biomass component of the fuel feed system. However, any further modifications or evaluation of operational changes are beyond the scope of this project.

\section{Task 4 - Laboratory-Scale Testing and Fuel Characterization}

Fuel characterization and laboratory-scale combustion testing were performed on coal and biomass parent fuels and on coal-biomass blends to define key combustion and ash behavior issues to monitor during pilot-scale combustion testing. Laboratory testing was carried out in the combustion and environmental process simulator (CEPS) in order to allow for the testing of a wider range of fuels at a lower cost. The CEPS is a modular system capable of producing gas and particulate samples for analysis to elucidate ash transformation and deposition mechanisms but does not simulate the exact geometry of a full-scale boiler.

\section{Fuel Characterization}

To identify the components leading to grate clinkering and ash fouling in a blend, it is essential to first understand the properties of the parent fuels. One representative coal (Cordero Rojo subbituminous) sample and two biomass fuels (wood chips and sunflower hulls) were selected for analysis and combustion testing. The coal is representative of common commercial use in regions where the selected biomass types are available. The coal and biomass fuels were selected for availability and either current use or the likelihood of future use in commercial applications. Final fuel selection and rationale were reviewed with the DOE COR.

All fuels were analyzed to fully characterize the inorganic and ash-forming constituents using

conventional and advanced techniques. The three parent fuels were submitted for analysis of particle 
size, bulk density, heating value, proximate-ultimate analysis, chlorine, and major ash chemistry (i.e., $\mathrm{SiO}_{2}, \mathrm{Fe}_{2} \mathrm{O}_{3}$, etc.).

Characterization of the Cordero Rojo subbituminous coal, wood chips, and sunflower hulls revealed significant differences. The biomass samples had a much lower moisture content than the coal but twice as much volatile matter. The fixed carbon for both the wood chips and the sunflower hulls was less than half of the Cordero Rojo coal. The sunflower hulls have almost twice the inorganic content as the coal, while the wood chips contain a very low percentage of inorganic material at $0.63 \%$. This is almost an order of magnitude lower than the coal and the sunflower hulls. Nitrogen content in the sunflower hulls was similar to that of the coal. The wood nitrogen level, however, was much lower by almost an order of magnitude. Sulfur levels in the fuels were $0.35 \%$ in the coal, $0.27 \%$ in the sunflower hulls, and $0.18 \%$ in the wood chips. Chlorine levels in the biomass fuels were significantly higher at 588 and $649 \mathrm{ppm}$ in the sunflower hulls and wood chips, respectively, while the coal only contained $57 \mathrm{ppm}$ (all on an as-received basis). This high chlorine content could potentially be a corrosion problem, warranting further investigation. Table ES-1 summarizes the proximate and ultimate analyses data for the coal and biomass fuels.

The inorganic distribution in the wood and coal is fairly similar, with the exception of the wood being enriched with alkali and alkaline-earth elements and the coal having a higher sulfur level, as previously stated. The sunflower hulls, on the other hand, contain significantly higher phosphorus and potassium than the coal, with almost $60 \%$ potassium and $8 \%$ phosphorus. The sunflower hulls have much less silica, alumina, and calcium compared to the coal and wood. Table ES-1 summarizes the bulk ash chemistry data for the coal and biomass fuels.

Advanced fuel analyses using chemical fractionation (CHF) and computer-controlled scanning electron microscopy (CCSEM) were also performed. These latter analysis techniques give a detailed picture of the mineralogy and chemistry of the inorganic fuel constituents not possible with conventional analysis. The data obtained from the advanced and conventional fuel analyses were used as input for two predictive models or indices to evaluate fireside performance: the model termed Predictive Coal Quality Effects Screening Tool (PCQUEST), developed at the EERC, and the Facility for the Analysis of Chemical Thermodynamics (FACT) model. The PCQUEST and FACT models complement each other, together providing a reasonable prediction of relative fireside performance.

The CHF analysis is a series of selective chemical leachings that quantify organically bound inorganic material and minerals that are less than $1 \mu \mathrm{m}$ in size. Organically bound inorganic material is found only in low-rank fuels and comprises the bulk of the inorganic material that is less than $1 \mu \mathrm{m}$ in size. Low-rank subbituminous and lignite coals act as ion-exchange materials, with alkali and alkaline-earth elements such as $\mathrm{Ca}^{++}, \mathrm{Na}^{+}$, and $\mathrm{K}^{+}$attaching to carboxylic acid groups in the coal. Up to half the calcium and all of the sodium and potassium present in the coal ash may be bound in this way. When the coal is burned, these highly dispersed elements have a high propensity to interact with other minerals present as well as form very fine ash. In the case of biomass fuels characterized in this study, it is believed that the majority of the inorganic material found to be leachable by water and ammonium acetate is in water-soluble form rather than organically associated as in coals. Generally, these materials will be more reactive than coal minerals because of a smaller size range but less reactive than organically associated materials. 
Table ES-1. Proximate and Ultimate Analysis of Fuels

\begin{tabular}{|c|c|c|c|c|c|c|c|}
\hline & $\begin{array}{c}\text { Cordero } \\
\text { Rojo } \\
\text { Coal } \\
\end{array}$ & $\begin{array}{c}\text { Sunflower } \\
\text { Hull } \\
\text { Biomass } \\
\end{array}$ & $\begin{array}{c}\text { Wood } \\
\text { Chip } \\
\text { Biomass }\end{array}$ & $\begin{array}{c}80 \% \\
\text { Coal- } \\
20 \% \\
\text { Sflr Hulls }\end{array}$ & $\begin{array}{c}60 \% \\
\text { Coal- } \\
40 \% \\
\text { Sflr Hulls }\end{array}$ & $\begin{array}{c}80 \% \\
\text { Coal- } \\
20 \% \\
\text { Wd Chips }\end{array}$ & $\begin{array}{c}60 \% \\
\text { Coal- } \\
40 \% \\
\text { Wd Chips }\end{array}$ \\
\hline \multicolumn{8}{|c|}{ Proximate Analysis, as-received, wt $\%$} \\
\hline Moisture & 26.3 & 11.60 & 7.30 & 23.36 & 20.42 & 22.50 & 18.70 \\
\hline $\begin{array}{l}\text { Volatile } \\
\text { Matter }\end{array}$ & 35.00 & 69.45 & 76.82 & 41.89 & 48.78 & 43.36 & 51.73 \\
\hline Fixed Carbon & 33.76 & 11.61 & 15.25 & 29.33 & 24.90 & 30.06 & 26.36 \\
\hline Ash & 4.94 & 7.34 & 0.63 & 5.42 & 5.90 & 4.08 & 3.22 \\
\hline \multicolumn{8}{|c|}{ Ultimate Analysis, as-received, wt $\%$} \\
\hline Hydrogen & 6.19 & 6.71 & 6.12 & 6.29 & 6.40 & 6.18 & 6.16 \\
\hline Carbon & 49.66 & 44.41 & 46.85 & 48.61 & 47.56 & 49.10 & 48.54 \\
\hline Nitrogen & 1.08 & 1.01 & 0.17 & 1.07 & 1.05 & 0.90 & 0.72 \\
\hline Sulfur & 0.35 & 0.27 & 0.18 & 0.33 & 0.32 & 0.32 & 0.28 \\
\hline Oxygen & 37.78 & 40.25 & 46.05 & 38.27 & 38.77 & 39.43 & 41.09 \\
\hline Ash & 4.94 & 7.34 & 0.63 & 5.42 & 5.90 & 4.08 & 3.22 \\
\hline $\begin{array}{l}\text { Heat Content, } \\
\text { Btu/lb }\end{array}$ & 8862 & 7815 & 8274 & 8653 & 8443 & 8744 & 8627 \\
\hline \multicolumn{8}{|l|}{ Chlorine, ppm } \\
\hline Dry Basis & 77 & 665 & 700 & 195 & 312 & 202 & 326 \\
\hline As Received & 57 & 588 & 649 & 149 & 248 & 156 & 265 \\
\hline \multicolumn{8}{|c|}{$\begin{array}{l}\text { X-ray Fluorescence (XRF) Analysis } \\
\text { Oxide, wt } \% \text { of ash }\end{array}$} \\
\hline $\mathrm{SiO}_{2}$ & 30.0 & 4.8 & 28.4 & 22.0 & 16.0 & 30.0 & 29.8 \\
\hline $\mathrm{Al}_{2} \mathrm{O}_{3}$ & 22.1 & 1.6 & 11.3 & 15.5 & 10.6 & 21.6 & 21.0 \\
\hline $\mathrm{Fe}_{2} \mathrm{O}_{3}$ & 7.4 & 0.7 & 10.3 & 5.3 & 3.7 & 7.4 & 7.7 \\
\hline $\mathrm{TiO}_{2}$ & 1.9 & 0.1 & 0.5 & 1.3 & 0.9 & 1.9 & 1.7 \\
\hline $\mathrm{P}_{2} \mathrm{O}_{5}$ & 1.2 & 8.0 & 1.4 & 3.4 & 5.0 & 1.2 & 1.2 \\
\hline $\mathrm{CaO}$ & 29.9 & 12.8 & 29.2 & 24.4 & 20.3 & 29.8 & 29.8 \\
\hline $\mathrm{MgO}$ & 5.5 & 9.9 & 6.1 & 6.9 & 7.9 & 5.6 & 5.5 \\
\hline $\mathrm{Na}_{2} \mathrm{O}$ & 1.7 & 0.0 & 5.0 & 1.1 & 0.8 & 1.9 & 2.1 \\
\hline $\mathrm{K}_{2} \mathrm{O}$ & 0.4 & 62.1 & 7.8 & 20.2 & 34.8 & 0.7 & 1.2 \\
\hline
\end{tabular}

\section{Laboratory-Scale Combustion Testing}

Entrained fly ash and deposits were obtained in the CEPS combustor for the parent coal and coal-biomass blends of 80-20 and 60-40 on a weight basis. The deposits were collected on removable cooled probes for analysis and determination of growth rates and deposit strength. The 
highest deposit growth rate was found for the parent coal fired without biomass. This deposit, however, had the lowest strength of any of the deposits generated. The highest-strength deposit was observed for the 60-40 coal-sunflower hull blend, which also had the lowest growth rate.

Particle-size distribution (PSD) gives some clues as to growth and strength development. Previous work conducted at the EERC indicates that biomass fuels tend to have inorganic constituents that are significantly smaller than those observed in coal, and this is what is seen with these biomass fuels. However, the data summarized in this report are from CCSEM analyses which can only measure particle sizes larger than $1 \mu \mathrm{m}$ and do not account for anything smaller. Smaller fly ash particles tend to remain entrained in the gas stream and flow around the tubes where largersize particles will have enough mass to leave the gas stream as it bypasses a tube, resulting in inertial impaction. Larger particles will also grow a deposit at a higher mass rate than the same number of small particles. Size distribution can also help to partially explain the strength development as well. Smaller particles have a greater surface area than larger particles and, given the same viscosity or stickiness, will bind a deposit together to a greater degree because of the larger amount of sticky surface available.

The PCQUEST model predicts a higher propensity for high-temperature fouling and slagging with the sunflower hull blends and only a slightly higher propensity with the wood chip blends when compared to the coal. This result is corroborated in the experimentally derived deposit sintering strength development. Figure ES-3 shows a backscattered electron image (BSE) of the 60-40 Cordero Rojo-sunflower hull blend deposit indicating the potassium-calcium-aluminosilicate bonding matrix essentially "gluing" the deposit together. The high concentration of potassium in the sunflower hulls reacted with the abundant calcium-aluminosilicates derived from the coal led to lower-melting-point phases of lower viscosity which tend to increase strength development in ash deposits. Figure ES-4 shows a BSE of the 60-40 coal-wood chip blend deposit, indicating a calcium-iron-aluminosilicate bonding matrix with iron crystallizing out of the melt. The crystallization of the iron can decrease the strength of the melt by creating areas that fracture more readily. The low ash content of the wood chips also contributed to a lower ash deposition rate and strength.

The tube erosion numbers were higher for the coal and are probably related to the greater content of larger silicate particles. The rest of the predictive values were relatively the same for all of the fuels.

Additional predicted ash deposition rates also agree with bench-scale combustion experiments. The deposition rate for the biomass blends was predicted to be the same or only slightly higher than that of the pure coal for the sunflower hulls and lower for the wood chips. This was observed in the deposition tests. This deposition rate formula was empirically derived for coal and may not apply directly to coal-biomass blends.

As previously stated, nitrogen content was similar for the coal and the sunflower hulls but much lower in the wood chips. However, this is not reflected in the flue gas $\mathrm{NO}_{\mathrm{x}}$ concentrations observed. Firing of the coal-biomass blends resulted in higher $\mathrm{NO}_{\mathrm{x}}$ concentrations than the parent coal. This can be explained by understanding the CEPS combustor system. Generally, the higher volatiles and moisture content of biomass fuels will tend to lower $\mathrm{NO}_{\mathrm{x}}$ concentrations when cofired with coal. The high volatiles content will create a fuel-rich, oxygen-lean combustion zone by fixing 


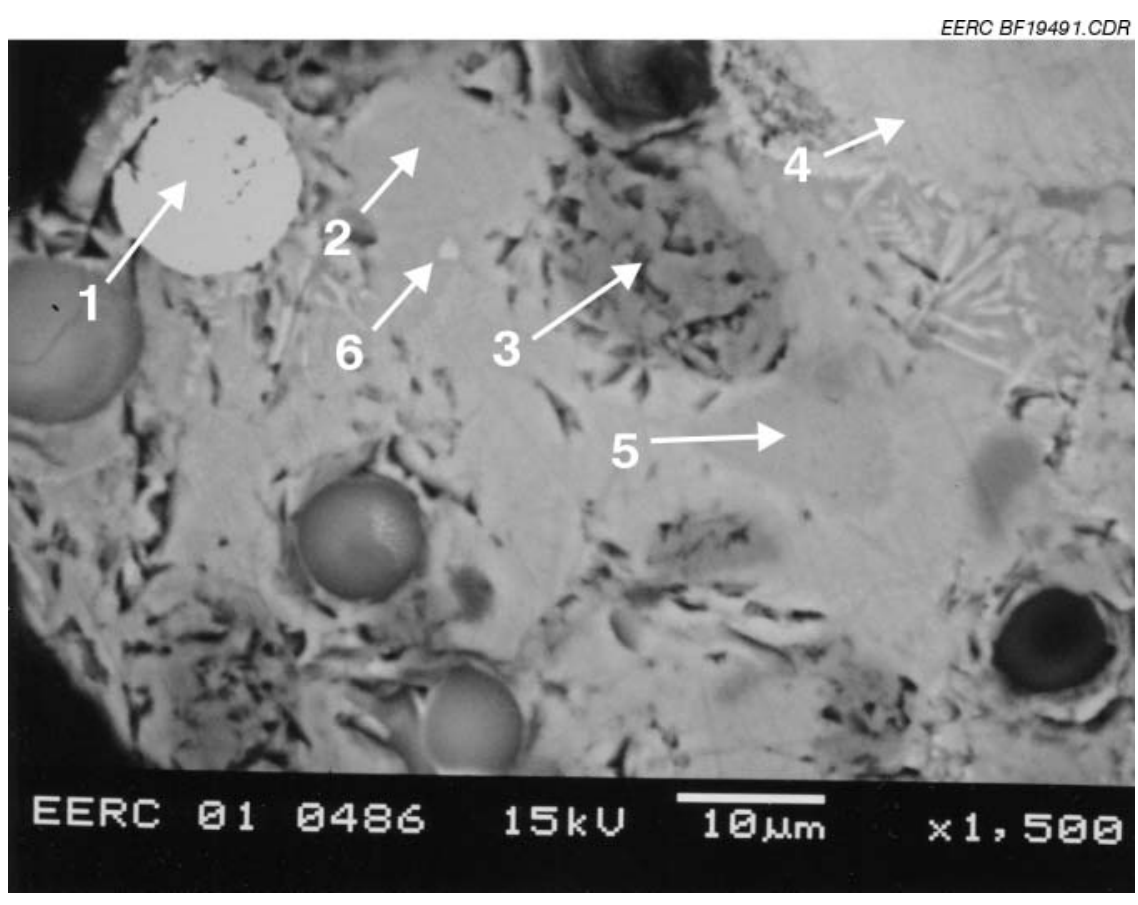

Figure ES-3. Scanning electron microscopy (SEM) micrograph of 80-20 Cordero Rojo-sunflower hull deposit ash.

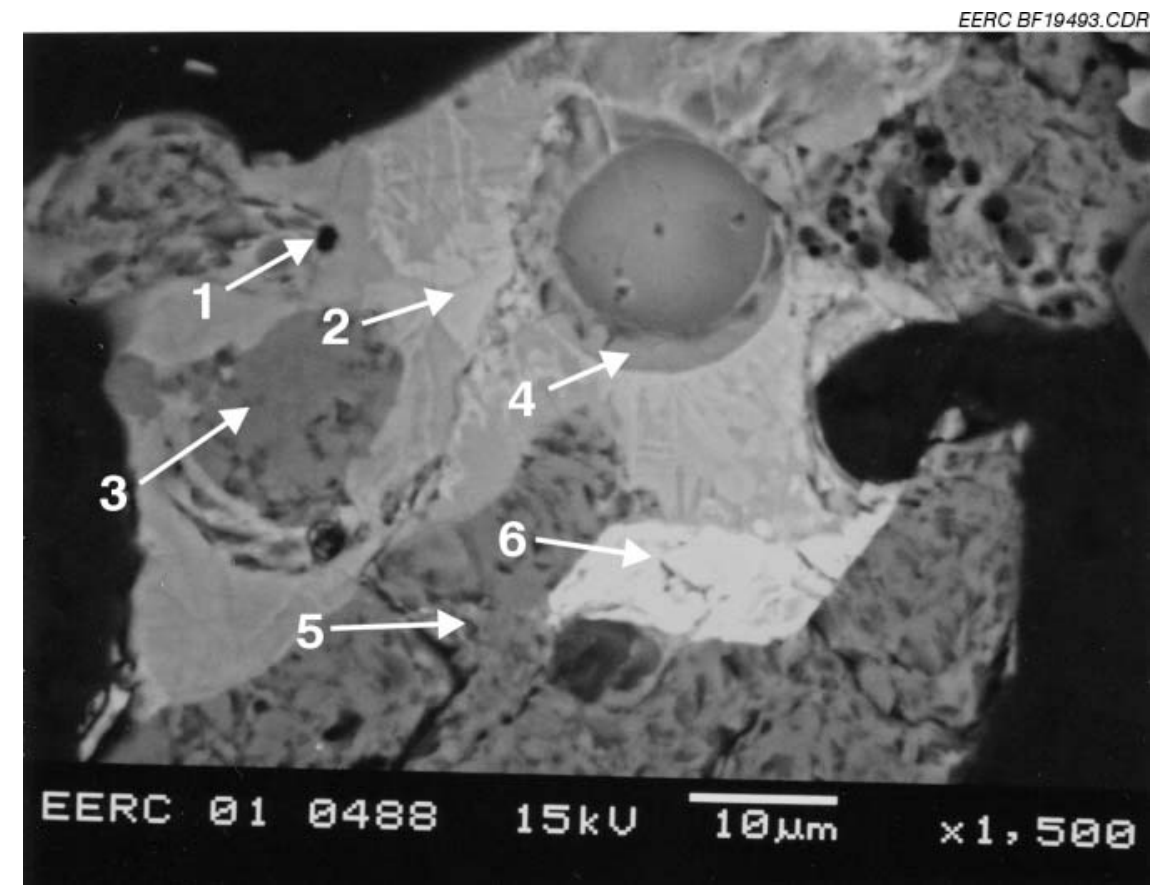

Figure ES-4. SEM micrograph of 80-20 Cordero Rojo-wood chip deposit ash. 
the oxygen much like a low- $\mathrm{NO}_{\mathrm{x}}$ overfire air combustion system while the higher moisture content will lower combustion temperatures and lower thermal $\mathrm{NO}_{\mathrm{x}}$. In the CEPS, the combustion temperature is not solely dependent on the flame since the entire furnace length is externally heated to ensure complete combustion. This may allow the combustion temperature to be maintained at a higher temperature than would be anticipated with no external heating. This would, in turn, increase the thermal $\mathrm{NO}_{\mathrm{x}}$ generation in the combustion zone. The sulfur levels were much lower in the biomass fuels, and this was directly reflected in the $\mathrm{SO}_{2}$ emissions observed.

One of the objectives of Task 4 was to make recommendations for the pilot-scale combustion tests of coal-biomass cofiring in Task 5 . The following recommendations were made:

1) Special provision should be made during the pilot-scale combustion test on the baseline fuel (Cordero Rojo subbituminous coal) to collect fine particulate data in the form of scanning mobility particle analyzer data (real-time particle-size measurement) and impactor or multicyclone particle capture and size segregation, with inductively coupled plasma-mass spectrometry analysis of ash and condensed species in the impactor or multicyclone stages and filter. This information will be critical to understanding the role of fine particulate and homogeneous or heterogeneous condensed species in forming initial fine ash deposits or fine particulate that could be difficult to control. Species of concern in the fine particulate are potassium chloride, potassium sulfate, potassium or calcium phosphates, and possibly others.

2) The pilot-scale tests should be performed at the 60-40 coal-biomass blend ratio since these seem to have the worst deposition properties.

3) $\mathrm{NO}_{x}$ and $\mathrm{SO}_{2}$ should be measured for the baseline coal and the blend fuels. The CEPS testing showed increased levels of $\mathrm{NO}_{\mathrm{x}}$ for the biomass blends which is contrary to current findings by the EERC and other research organizations.

Overall, the characterization data provide a consistent overview of the likely combustion characteristics of coal-biomass-blended fuels containing Cordero Rojo coal, sunflower hulls, and wood chips. Proximate-ultimate analyses show that both biomass fuels have significantly higher chlorine content than the coal which could potentially cause problems with corrosion and should be investigated thoroughly before implementing plans to cofire or blend biomass with coal. The fly ashsize distribution data indicate a potential for opacity problems due to the smaller fly ash size of blended fuels. This is also an area that needs to be investigated further in light of current and anticipated fine particulate regulations.

Past work at the EERC has demonstrated the importance of understanding the mechanisms behind inorganic interactions that can drastically affect fuel and boiler operations. The current models used for predicting the behavior of coals in combustion environments have been shown here to be not quite adequate to identify problems before they occur in real time. A good theoretical or empirical model of inorganic transformations during biomass cofiring is certainly needed. 


\section{Task 5 - Pilot-Scale Testing and Reporting}

\section{Pilot-Scale Combustion Testing}

Based on the results of the laboratory-scale work (Task 4), one combustion test was completed in the pilot-scale grate-fired system firing coal, and two tests were completed cofiring coal and biomass. The primary fuel was Cordero Rojo subbituminous coal. Each of the two biomass fuels, wood chips and sunflower hulls, were fired at nominally $40 \mathrm{wt} \%$ based on the laboratory-scale combustion test results. Each combustion test included a full suite of gas sampling, ash sampling, and deposit sampling similar to that performed in the laboratory-scale testing. Overall, the pilotscale stoker-fired system was shown to work well with respect to achieving desired combustion conditions. Minor problems were noted with biomass fuel feed and clinker formation. Both of these problems were overcome using manual mitigation techniques at regular intervals. Furnace exit gas temperatures during the pilot-scale tests ranged from $1021^{\circ}$ to $1065^{\circ} \mathrm{C}\left(1870^{\circ}\right.$ to $\left.1948^{\circ} \mathrm{F}\right)$.

Ash deposition on convective surfaces was minimal for all tests, baseline coal as well as the coal-biomass cofiring tests. Only a few grams of ash were sticking to the ash deposition probe, and the material was mostly calcium and potassium sulfates. The resulting deposition observed would not significantly reduce the capability of a boiler to produce steam. Deposition characteristics indicated that the high calcium in the coal-wood chip blend and the high potassium in the coal-sunflower hull blend could create some lower-viscosity bonding material, but in this pilot-scale stoker system there was little evidence of problematic ash deposition. Slightly higher $\left(56^{\circ} \mathrm{C}\right.$, or $100^{\circ} \mathrm{F}$ ) furnace exit gas temperatures could trigger more severe fouling. Also, the quantity of fly ash generated during these tests was lower than considered typical for stoker-fired applications. Therefore, these observations may have been influenced by grate clinker formation.

The clinker formation and the manual techniques used to dislodge clinkers from the grate and walls led to agitation of the bed, creating an intense combustion environment with well-mixed fuel and air. This led to immediate and dramatic reduction in excess air levels and momentary high $\mathrm{CO}$ production and carbon carryover. It is recommended that in future tests adjustments to operating parameters be made to run the bed leaner in combustion air, using higher percentages of overfire air to complete combustion. It is expected that this may lead to a less active bed and lower bed temperatures, resulting in decreased clinker formation and, potentially, lower carbon carryover.

Fly ash PSD was shown to decrease when biomass was introduced in blend with the coal. This was expected because of the fine size of the fuel minerals in the biomass and the preponderance of organically associated alkali metals and alkaline-earth components. In terms of fly ash generation, the alkalies can be expected to form fine particulates in the form of potassium sulfate, potassium phosphate, chlorides, and calcium sulfate, among other fine species. In addition, the agitation of the bed to remove clinkers from the walls and grate tended to generate fine carbon soot particles as excess air levels dropped, resulting in a further increase in the fine particulate portion of the fly ash. The shift to a finer particle size could be problematic for units with small precipitators or, in some cases, old stokers still using multicyclones for particulate control. It is recommended that units lacking adequate ESP surface or using multicyclones consider ESP upgrades or installation of fabric filters for collection of fine particulate to meet emissions standards. 
Gaseous emissions of both $\mathrm{SO}_{2}$ and $\mathrm{NO}_{\mathrm{x}}$ were shown to decrease relative to the baseline coal when biomass was introduced as part of the fuel mix. Both biomass fuels contained lower sulfur contents than did the coal, and the higher alkaline content of the biomass led to increased sulfur capture in the ash. Nitrogen oxide emissions were reduced $20 \%$ during combustion of the coal-wood chip blend and $10 \%$ during combustion of the coal-sunflower hull blend. However, the higher FEGT observed during the coal baseline test may have been a contributing factor to the $\mathrm{NO}_{\mathrm{x}}$ emissions observed.

Further modifications to the pilot-scale grate-fired combustor are likely to improve performance and increase unit flexibility. The primary goal of these modifications would be to decrease metal temperatures on the grate in the near-grate region. A more sophisticated watercooling system for the grate would help to reduce metal warping and fatigue and would provide better operational control of fuel-bed temperature on the grate. In addition, operational changes would further reduce grate clinkering and result in other improvements in overall combustor performance. Some of these include reducing fuel particle size, reducing the thickness of the fuel bed on the grate, changes in primary and overfire air distribution, and changes to the biomass component of the fuel feed system. The reactive nature of the coal and biomass creates an intense combustion environment in the near-grate region. As a result, high bed temperatures were achieved, resulting in clinker formation. A finer particle size, reduction of fuel bed height, and utilizing a greater percentage of overfire air may be expected to greatly increase control of fuel-bed temperatures and reduce ash clinkering. As previously discussed, a screw feeder may be a better option for delivery of some biomass types. Other options may include air-assisted feeder configurations. However, any further modifications or evaluation of operational changes are beyond the scope of this project and would be addressed in future projects.

\section{Reporting}

Project accomplishments and problems were documented in monthly status reports and semiannual technical progress reports, with all of the project results compiled in a final technical report. In addition, information developed as a result of this project was summarized and presented at nine technical conferences. A draft final technical report was submitted to the DOE COR for review and comment prior to this final technical report being issued. 


\section{BARRIER ISSUES TO THE UTILIZATION OF BIOMASS}

\subsection{INTRODUCTION}

Well over half of the electric generation in the United States is derived from coal. Many electric utilities that use coal for power generation are considering the use of renewable fuels such as waste products or energy crop-derived biomass fuels as a potential economical option for reducing greenhouse gas emissions. Calculations by the National Renewable Energy Laboratory (1) show that cofiring $15 \%$ and $5 \%$ by heat input of urban waste biomass with Illinois No. 6 coal reduces greenhouse gas emissions by $22 \%$ and $7 \%$, on a $\mathrm{CO}_{2}$-equivalent basis per unit of electricity produced. Therefore, biomass cofiring in coal-fired plants has the potential to significantly reduce greenhouse gas emissions. Questions arise as to the availability of biomass resources, modifications that may be necessary for existing plants, and the global greenhouse gas inventory. Therefore, the greatest potential for the utilization of biomass exists for smaller boilers used for heating and generation of process steam represented by older stoker-fired units and newer fluid-bed combustion units.

Some experts estimate that $14 \%-15 \%$ of total world energy consumption is already accounted for by biomass (2). Energy production from biomass fuel sources such as wood wastes, municipal wastes, agricultural wastes, and landfill or digester gases is currently only about $1 \%$ of the total U.S. output (3). However, recent projections show that production capacity could rise to $10 \%$ of the total U.S. output by the year 2010 (4), if more companies take on cofiring strategies and if dedicated sources of energy crops are produced (5). The European Union (EU), in response to the Kyoto Protocol, committed to reduce greenhouse gas emissions between 2008 and 2012 by $8 \%$ compared to 1990 levels. EU statistics show that currently about $2 \%-8 \%$ more $\mathrm{CO}_{2}$ would be emitted within the EU without the current use of biomass (6). Estimates of remaining available solid biomass fuel potential indicate that further reduction of $\mathrm{CO}_{2}$ emissions of $7 \%-28 \%$ could be achieved.

The global inventory of greenhouse gas emissions remains a serious problem since many countries have little incentive to reduce greenhouse gas emissions. Treaties such as the Kyoto Protocol will hopefully create incentives. In the Netherlands, an additional incentive for the use of biomass wastes is the governmental policy to aim for a strong increase in renewable energy use ( $10 \%$ of the primary energy consumption in $2020,4 \%$ from biomass and biomass wastes). Cofiring biomass and biomass waste streams with fossil fuels in large-scale power plants is considered to be an attractive option, since it benefits from the economy of scale and can potentially be realized at relatively low investment cost (7). If U.S. companies pursue biomass-cofiring opportunities in a manner comparable to European experience, biomass cofiring in the United States could have a significant impact on the global greenhouse gas pool.

Biomass types available for use as cofiring fuels with coal fall into two major categories: biomass wastes and biomass energy crops. Waste products include wood wastes such as wooden pallets, telephone poles, sawdust, manufacturing scraps, and municipal solid waste (MSW) or sludge. Agricultural wastes may include peach pits, rice hulls, and straws of wheat, alfalfa, rape, timothy, and barley. Energy crops include fast-growing switchgrass and hybrid trees such as poplar and willow. European research into direct firing and cofiring biomass with coal for power generation

has been fairly extensive with various agricultural biomass fuels such as wheat straw and wood 
waste product fuels (8-13). In the United States, research has focused primarily on cofiring arrangements for wood (14-21), and more localized agricultural waste biomass fuels have been studied less intensely (22-26). A recent synopsis of biomass for energy production, written by European researchers, discussed issues and barriers to using biomass such as wood for energy production (27). Biomass combustion is considered to have the following impacts: provides excellent reduction of greenhouse gases, decreases $\mathrm{NO}_{\mathrm{x}}$, destroys polychlorinated biphenyls, decreases smog, increases volatile organic compounds (greatly dependent upon combustion process), decreases $\mathrm{CO}$, stimulates landscape and forest conservation, and reduces soil erosion if the wood source is from dedicated resources such as tree farms (27-28).

Biomass utilization by conventional coal-fired utilities will create some technical challenges (29). Design limitations of coal-fired boilers may also preclude the use of biomass beyond certain weight fractions of total fuel feed. Such limitations may include physical processing of the biomass for proper injection or feeding into the boiler. Other limitations include fireside performance of the biomass, including its impact on flame stability, boiler heat exchanger surface fouling or slagging, and corrosion. With respect to processing and feeding biomass, various utilities in Europe and the United States have either developed size-reducing methods that facilitate feeding the more fibrous and pliable biomass fuel into the boiler, or in many cases, separate injection ports have been installed $(8,9)$. Ash deposition and boiler tube corrosion can be an issue because biomass can contain considerable alkali and alkaline-earth elements and chlorine which, when mixed with other gas components derived from coal such as sulfur compounds, promote a different array of vapor and fine particulate deposition in a coal-fired boiler $(8-10,13,24)$. Biomass can also contain organically deposited minerals such as amorphous silica phytoliths (30) which are difficult to characterize with standard coal analysis methods and which also behave differently than mineral silica forms such as quartz in coal. Initial assessments have been performed on the behavior of inorganic constituents of biomass during combustion (31) as well as on issues related to the cofiring of biomass-coal blends (32).

Utilization of biomass in stoker boilers designed for coal can be a cause of concern for boiler operators. Kautz determined that German boilers that were designed for low-volatile fuels with lower reactivities experienced damaging fouling when the boilers were switched to higher-volatile and more reactive lower-rank fuels, similar to what could be expected when firing biomass (33). Higher heat release rates at the grate caused more clinkering or slagging at the grate because of higher temperatures. Combustion and loss of volatiles essentially started too early for the lower-rank fuel compared to the design fuel, vaporizing alkali and chlorides which then condensed on rear walls and heat exchange tube banks in the convective pass of the stoker causing noticeable increases in fouling. Williams et al. performed slagging and fouling assessments at three 17-MW stoker-fired boilers, focusing on the effects of furnace exit gas temperatures on superheater fouling (34). Wood and almond shells were fired in the units, and higher rates of ash accumulation were noted for the higher-exit-temperature runs (maximum of $950^{\circ} \mathrm{C}, 1742^{\circ} \mathrm{F}$ ) versus the lower-exit-temperature runs (maximum $800^{\circ} \mathrm{C}, 1472^{\circ} \mathrm{F}$ ). Potassium sulfates and carbonates were increased in the deposits at the higher temperatures, but chlorides were very evident at the lower temperatures. These results are significant in that stoker-fired boilers that may switch to biomass blends may encounter new chemical species such as potassium sulfates and various chlorides in combination with different flue gas temperatures because of changes in fuel heating value, which can adversely affect ash deposition behavior. 
Work by Frandsen et al. and Nielsen et al. studied ash deposition mechanisms for grate-fired boilers that had been converted from coal to straw fuel $(35,36)$. Findings included high concentrations of submicron aerosols for $100 \%$ straw combustion compared to coal-straw cofiring. Also, fly ash and ash-fouling deposits were produced which were very high in potassium chloride for $100 \%$ straw firing and much lower in chlorides for cofiring tests with coal because of interactions of potassium with coal silicates. Similar mechanisms of biomass combustion aerosol development were observed by Obernberger et al., and similar interactions between coal silicates and biomass chlorides and potassium compounds were reported by Folkedahl et al. and Zygarlicke et al. using simulated combustion testing to study the fundamentals of cofiring coal and wood, wheat straw, alfalfa stems, and rice straw lignin (37-44).

Stoker-fired boilers that cofire or switch to biomass fuel will undergo changes in ash behavior, such as production of different concentrations and quantities of fine particulate or aerosols, ash deposition rates, and the strength of ash deposits. In some cases, these changes may be beneficial and, in other cases, problematic. Stoker boiler operators that are considering switching to biomass and adding potential infrastructure to accommodate the switch may, at the same time, be looking into upgrades that will allow for generating additional steam or cogeneration of power for on-site use and/or sale on the grid.

\section{U.S. Biomass Resources}

In most U.S. locations, the availability of biomass as a fuel feedstock is not reliable beyond $20 \%$ of what is a normal firing rate for coal. Cofiring biomass up to $20 \%$, therefore, is a practical application for incorporating a renewable energy fuel into a coal-fired plant. Figure 1 shows the location of current agricultural and forest activities where biomass resources are available in the form of residuals (45). Agricultural residuals are primarily available in the Midwest, Southeast, and mid-Atlantic regions, where there is a significant amount of farming activity. Forest resources and residuals are available in the New England, mid-Atlantic, Southeast, and upper Midwest regions, as well as in the Pacific Northwest. Promising locations for various species of biomass energy crops are shown in Figure 2 (45).

Biomass has the potential to supply 24.7 PJ (23.5 quads) of energy for the United States, which represents approximately $28 \%$ of U.S. energy consumption. This potential, as a function of the four major biomass categories, includes the following (46):

- Wood residuals - 3.7 PJ (3.5 quads)

- Agricultural residuals (from crops, food processing, and animals) - 1.7 PJ (1.6 quads)

- Dedicated energy crops - 17 PJ (16.1 quads)

- Urban wastes - 2.1 PJ (2.0 quads)

The alternative fuels under each category that can be considered as a resource for cofiring are listed in Table 1. To some extent, all of these fuels are candidates for use in industrial and institutional stoker-fired combustion units. The availability of each resource, however, may be limited to certain areas. A recent study completed by Schmidt and Pinapati concluded that collectible quantities of biomass (excluding energy crops) totaled 7 PJ (6.65 quads) (47). 


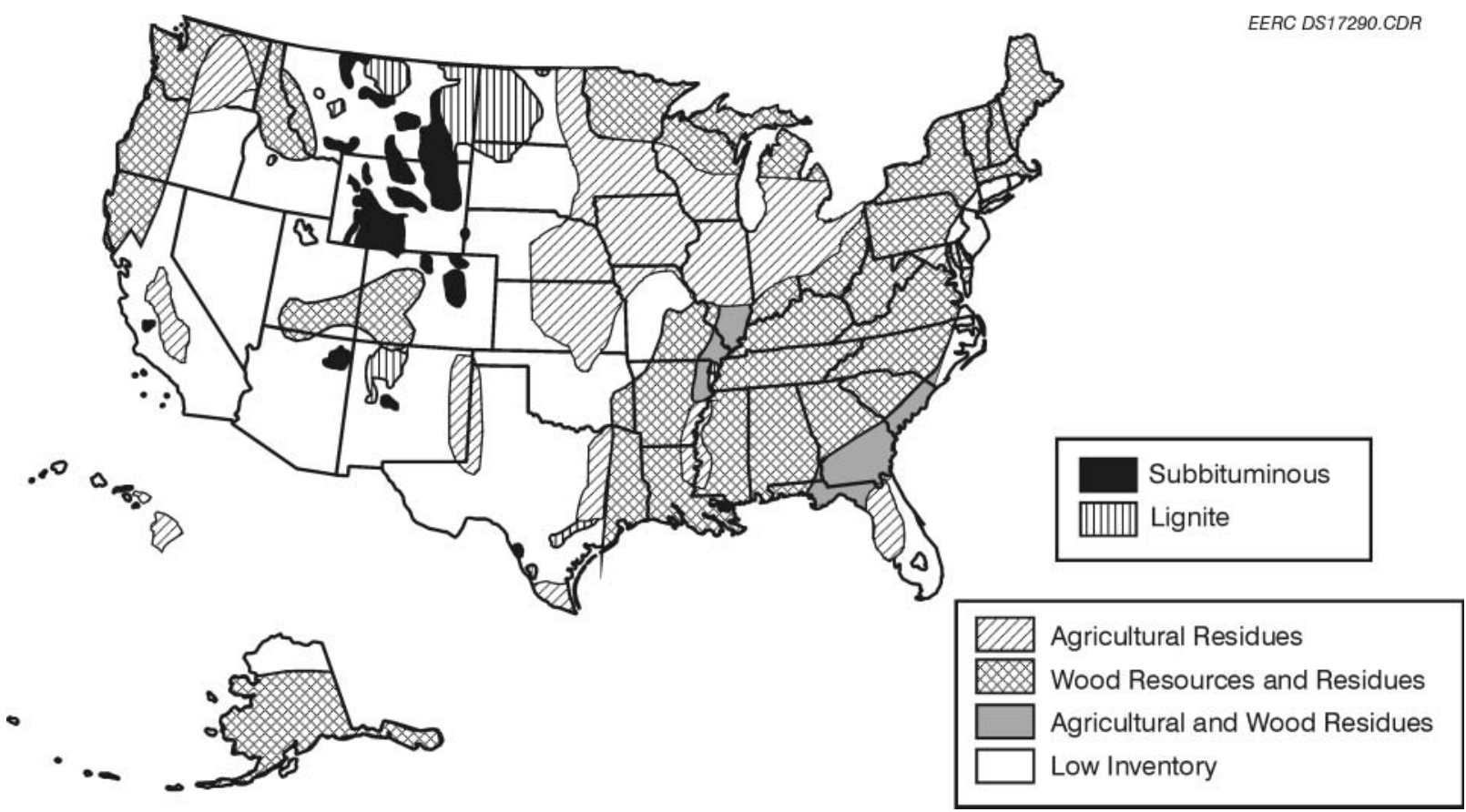

Figure 1. Location of agricultural and forest residues (45).

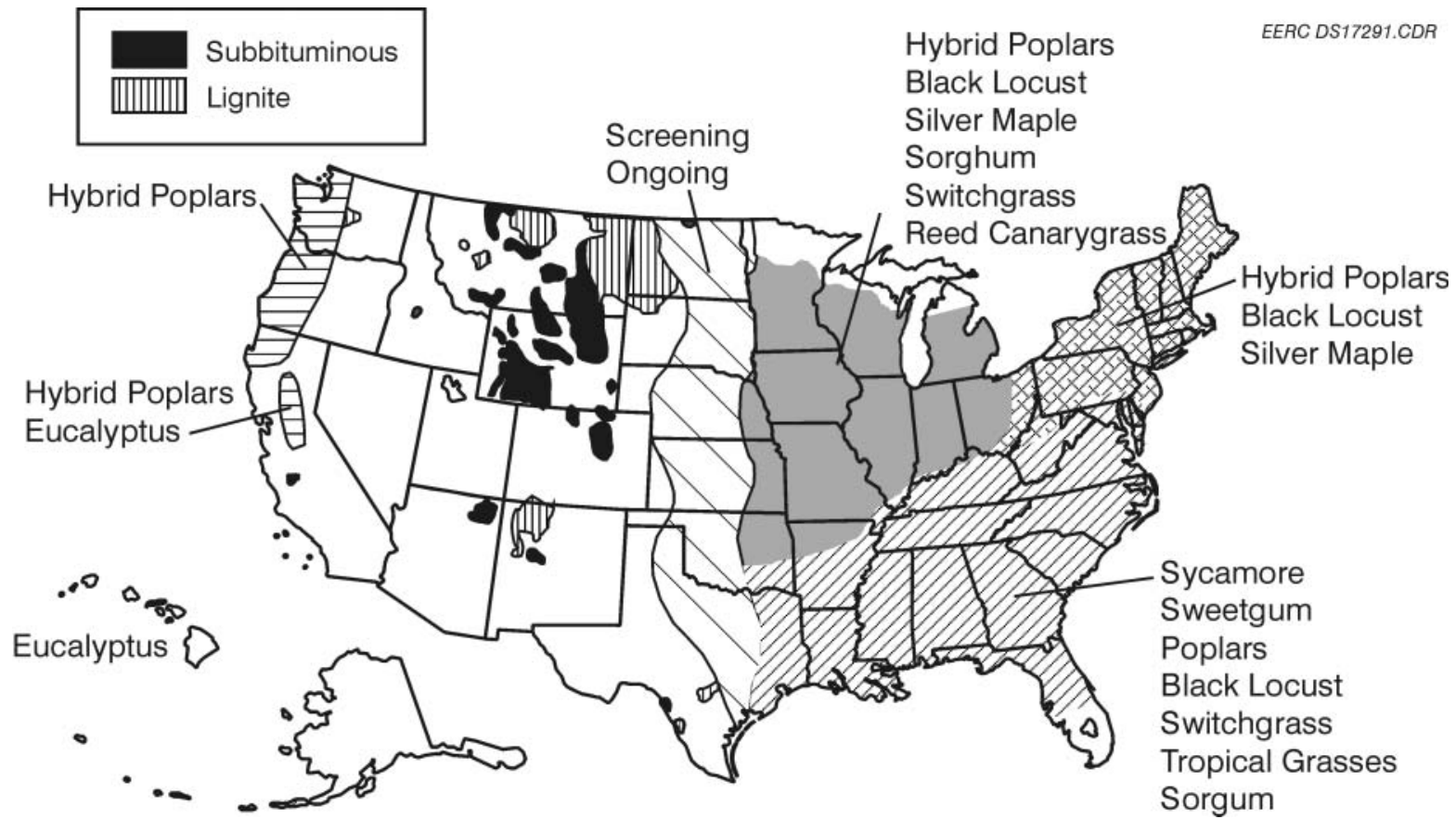

Figure 2. Promising locations for biomass energy crops (45). 
Table 1. Biomass Subtypes

\begin{tabular}{llll}
\hline Agriculture Based & \multicolumn{1}{c}{ Forest Products } & \multicolumn{1}{c}{ Urban Wastes } & \multicolumn{1}{c}{$\begin{array}{c}\text { Dedicated } \\
\text { Energy Crops }\end{array}$} \\
\hline $\begin{array}{l}\text { Harvest Residuals } \\
\text { Wheat Straw }\end{array}$ & $\begin{array}{c}\text { Logging Residuals } \\
\text { Cull trees }\end{array}$ & \multicolumn{1}{c}{ Residential } & \multicolumn{1}{c}{ Grasses } \\
Rice Straw & Tops & MSW & Switchgrass \\
Flax Straw & Dead wood & RDF (refuse-derived fuel) & Native grasses \\
Cornstalks & Small-diameter stock & Mixed paper & \\
& & Yard waste & \\
& & Demolition wood waste & \\
& Pcrap tires & \\
Processing Residuals & Processing Residuals & Urban and Landscape Residue & Trees \\
Rice Hulls & Sawdust & Leaves and grass clippings & Willow \\
Sugarcane Bagasse & Bark & Chipped and unchipped wood & Cottonwood \\
Almond Shells/Hull & Edgings & Construction and demolition & Hybrid poplar \\
Olive Pits & Slabs & waste & \\
Sugar Beet Pulp & & Pallets/scrap & \\
Sunflower Hulls & & Railroad ties & \\
& & & Alfalfa stems \\
Animal Wastes & Processing Residuals & & Specialty crops \\
Poultry Litter & Sawdust & & \\
Feedlot Wastes & Edgings & & \\
\hline
\end{tabular}

Large volumes of wood residuals are generated by the wood products industry, including paper mills, sawmills, and furniture manufacturing. While the wood products industry currently uses much of its own residuals, there is still a substantial amount available, particularly from smaller sawmills that individually have too little waste wood to justify investing in steam or power production. In cases where a number of these smaller mills are in the same vicinity, a centrally located plant can purchase residuals from sawmills within an approximately $120-\mathrm{km}$ (75-mile) radius to secure a supply of wood residuals sufficient to generate a significant amount of steam and/or power. Another significant source of wood residuals is forestry or "culls" from forest management (precommercial thinning of commercial forests, where dead, dying, or unmerchantable trees are selectively removed to increase the productivity of forests).

Wood residuals obtained from sound forest management do not deplete the net forest resource base. Through sustainable practices, trees are either replanted or the forest resource is managed for regeneration to enhance its health and productivity in the future. In some areas of the country, like the Tahoe Basin, forest management is essential to prevent major forest fires.

Agricultural residuals offer substantial energy resources for various applications. Crop residuals, processing residuals, and food-processing wastes are some components of the agricultural residual supply that can be used on-site or in regional facilities. Open-field burning of agricultural 
residuals was a common practice until recently, when the practice was banned in many locations because of air pollution concerns. Opportunities to use these residuals for fuel have been tempered, however, by a number of concerns related to their transport, handling, and impact on combustion system performance.

Dedicated energy crops, including short-rotation woody crops and herbaceous crops (primarily tall grasses such as switchgrass) represent the greatest potential source of biomass resources. Hybrid poplar and willow are two more common trees being studied for energy production. These trees will regrow vigorous shoots from the tree stumps that remain after harvesting, a form of regrowth that is known as coppicing. The resulting abundant new growth can then be harvested again in 5 to 10 years. The ability to obtain numerous harvests from a single planting significantly reduces average annual costs for establishing and managing energy crops.

Production of energy crops also requires much less intensive management than for most traditional agricultural crops, especially in terms of lower inputs of fertilizers and pesticides. In addition, because the root systems of energy crops remain in the ground between harvests, energy crops can help reduce soil erosion. The current cost of growing, harvesting, and transportation of dedicated energy crops exceeds that of other "waste" biomass (as well as some fossil fuels), so subsidies of some sort or a mandatory percentage of biomass in the fuel mix will be required to promote near-term use of these materials.

MSW represents another significant source of biomass fuel. In the United States, paper and other organic materials typically represent a large portion of the waste stream - materials that make good combustion feedstock. Typically, $90 \%$ of the volume of MSW is combustible material. Other municipal and industrial wastes could also fuel an energy plant. Urban wood waste is another source of wood residuals, including tree trimmings, right-of-way and land clearance, waste wood from construction and demolition, broken wood pallets, fruit boxes, and other wood packaging. Nonbiomass urban wastes, including sewage sludge, also represent potential sources of energy in urban areas.

\section{Technical Issues of Biomass Combustion}

The usable energy in biomass typically ranges from about 15,105 to $19,752 \mathrm{~kJ} / \mathrm{kg}$ (6500 to $8500 \mathrm{Btu} / \mathrm{lb}$ ) on a dry basis. However, biomass is generally not delivered dry. On a wet (green) basis, biomass typically has a moisture content of from $40 \%$ to $50 \%$, which reduces the energy value of green hardwoods to about $9295-10,457 \mathrm{~kJ} / \mathrm{kg}(4000-4500 \mathrm{Btu} / \mathrm{lb})$. The moisture content of a single source of biomass fuel delivered to a plant can vary significantly because of differences in factors such as harvesting, storage, and drying conditions. Biomass with a heating value of $<8133 \mathrm{~kJ} / \mathrm{kg}(<3500 \mathrm{Btu} / \mathrm{lb})$ would be of little value to a suspension-fired or grate-fired plant, since it would require a net energy input in order to sustain combustion.

Physical characteristics vary widely with biomass materials. For example, wood and grass have very different bulk densities. Nonwoody biomass spans a much wider range of characteristics than woody biomass. The bulk density of woody material is generally in the range of $160-240 \mathrm{~kg} / \mathrm{m}^{3}$ $\left(10-15 \mathrm{lb} / \mathrm{ft}^{3}\right)$. When biomass is densified by processing and compaction, its bulk density can be increased by 2 to 3 times. For example, the bulk volume of RDF, a processed form of MSW, is in 
the range of $400-433 \mathrm{~kg} / \mathrm{m}^{3}\left(25-27 \mathrm{lb} / \mathrm{ft}^{3}\right)$. By comparison, the bulk density of coal is approximately $721 \mathrm{~kg} / \mathrm{m}^{3}\left(45 \mathrm{lb} / \mathrm{ft}^{3}\right)$.

At the other end of the spectrum, agricultural materials such as loose straw can have a bulk density in the range of 16 to $40 \mathrm{~kg} / \mathrm{m}^{3}$ ( 1 to $2.5 \mathrm{lb} / \mathrm{ft}^{3}$ ), although chopping or baling this type of material significantly increases its density. The tendency toward low weight per unit of volume translates into higher transportation costs. Thus options such as baling that keep the density higher for transportation purposes are especially important in considering the use of agricultural residuals (or herbaceous crops such as switchgrass). Their lower bulk density also means that special consideration must be given to handling and processing these materials as well as feeding them into combustion systems.

An important consideration for biomass is that the ash from some agricultural residuals and from new tree growth (e.g., the tops of trees or the ends of tree limbs) can have a relatively high alkaline metal content, particularly potassium and sodium. These alkaline metals tend to lower ash melting temperatures and can increase ash deposition and fouling of boiler equipment. Other ash constituents such as chlorine, silica phytoliths, and phosphorus can play a major role in developing ash deposits and fine particulate emissions. Special precautions like temperature control can be taken to limit fouling. However, there will be certain biomass materials that will only make an acceptable fuel when blended with other low-alkali biomass or coal in cofiring applications. Biomass materials high in silica, such as rice hulls, can cause erosion problems in the convective pass of the boiler; however, proper selection of gas velocities and selective use of refractory can minimize the erosion.

The inert materials, plastics, and various types of contaminants in municipal waste are a concern when using these materials to produce energy. Experience with separation and processing of municipal waste into RDF and cofiring in boilers has shown that RDF can be an acceptable fuel for some boiler applications, especially fluid beds. Fluid-bed systems are much more forgiving of this "tramp" material than other combustion systems. Chlorine corrosion can be a concern with materials high in plastics.

The primary characteristics of biomass that require special attention when it is used as a fuel are summarized in Table 2. In all except the extreme cases, the stoker in combination with cofiring can be designed to deal with these troublesome characteristics.

\section{Biomass Power Systems}

The characteristics of biomass power systems make it difficult for biomass to compete as a source of energy. The capital costs associated with biomass energy production are higher than those for conventional technologies, in part because of the extra emphasis that must be placed on fuel delivery and storage and handling systems and the higher costs associated with the reverse economies of scale for small systems. In addition to high capital costs $(0.8$ to 1.4 cents/MJ, or 3 to 5 cents $/ \mathrm{kWh})$, biomass systems typically have high fuel costs $(0.6$ to 1.1 cents/MJ, or 2 to 4 cents $/ \mathrm{kWh}$ ) and high operating and maintenance costs ( 0.8 to 1.4 cents/MJ, or 3 to 5 cents $/ \mathrm{kWh}$ ). The low efficiencies $(<30 \%)$ of these systems also play an important role in keeping costs high. 
Table 2. Fuel Characteristics Requiring Special Attention

\begin{tabular}{|c|c|c|c|}
\hline Fuel Property & $\begin{array}{l}\text { Troublesome } \\
\text { Characteristics }\end{array}$ & Potential Problem & Proposed Solution \\
\hline \multirow[t]{2}{*}{ High Alkali $(\mathrm{Na}, \mathrm{K})$} & \multirow[t]{2}{*}{$\begin{array}{l}\text { Formation of low- } \\
\text { melting-point } \\
\text { compounds }\end{array}$} & $\begin{array}{l}\text { Slagging/fouling of } \\
\text { convective surfaces }\end{array}$ & $\begin{array}{l}\text { Low convective pass } \\
\text { temperature }\left(<1400^{\circ} \mathrm{F}\right) \\
\text { Sootblowing }\end{array}$ \\
\hline & & Sintering on the grate & $\begin{array}{l}\text { Low firing temperature } \\
\text { Fuel mixing (dilution) }\end{array}$ \\
\hline $\begin{array}{l}\text { Scrap Material } \\
\text { Rock }\end{array}$ & $\begin{array}{l}\text { Accumulation of rock and } \\
\text { metal }\end{array}$ & $\begin{array}{l}\text { Plugging, mechanical } \\
\text { breakdown }\end{array}$ & Tramp removal system \\
\hline $\begin{array}{l}\text { Dirt } \\
\text { Metals } \\
\text { Glass }\end{array}$ & $\begin{array}{l}\text { Glass and aluminum } \\
\text { become molten }\end{array}$ & $\begin{array}{l}\text { Sintering } \\
\text { Convective pass } \\
\text { fouling }\end{array}$ & $\begin{array}{l}\text { Presorting } \\
\text { Sootblowing }\end{array}$ \\
\hline \multirow[t]{2}{*}{ Chlorine } & $\begin{array}{l}\text { Formation of alkali } \\
\text { chlorides and } \mathrm{HCl}\end{array}$ & Corrosion & $\begin{array}{l}\text { On-grate chlorine capture } \\
\text { Fuel mixing/dilution }\end{array}$ \\
\hline & $\begin{array}{l}\text { Formation of chlorinated } \\
\text { organic compounds }\end{array}$ & $\begin{array}{l}\text { Emissions exceeding } \\
\text { local, state, or } \\
\text { federal limits }\end{array}$ & $\begin{array}{l}\text { Combustion air and } \\
\text { temperature control }\end{array}$ \\
\hline \multirow[t]{2}{*}{ Bulk Density } & Low bulk density & $\begin{array}{l}\text { High transportation } \\
\text { costs }\end{array}$ & Baling (compacting) \\
\hline & & High processing costs & $\begin{array}{l}\text { Hydraulic ram feeder } \\
\text { Fuel preparation }\end{array}$ \\
\hline
\end{tabular}

Direct combustion of biomass for energy production was initially viewed as a suitable replacement for fossil fuels. Ash-related problems, including slagging, agglomeration, corrosion, and erosion, can cause frequent unscheduled shutdowns, decreasing the availability and reliability of this energy source. In addition, fouling of heat exchange surfaces coupled with the high moisture in the fuel reduces system efficiency. The variable nature of the quality of biomass fuel also impacts the reliability and availability of biomass systems.

The current status of the deregulated power industry has a significant impact on the introduction of new biomass power systems. The restructuring of the electricity market has shifted the focus from diversification of electricity-generating technologies to a least-cost approach to generating electricity. Deregulation-related barriers to the biomass industry include market prices, long-term capital investment risks, and inadequacies in alternative energy subsidies. The ability to command high prices for biomass-based power that was present under the Public Utility Regulatory Policy Act and other legislative actions has virtually disappeared, forcing biomass power to compete directly with other energy sources. In addition, the current transmission and dispatch market has not been developed to the point where a small, independent power producer can effectively negotiate a contract and cost-effectively sell power to the grid. Concerns over power quality also factor into the reluctance of the transmission companies to deal with small electricity producers.

Given the current status of biomass fuel options, utilization experience, and the market forces driving the utility and industrial sectors, an excellent near-term opportunity for biomass utilization within the United States is for biomass residuals and energy crops in small industrial-type boilers 
(commonly grate-fired systems). The primary technical hurdle is interaction of the inorganic components causing grate clinkering, heat exchange surface fouling, and fine particulate emissions. Other technical concerns relate to fuel handling and preparation.

Based on the literature previously cited and additional information gathered from personal communications with key biomass combustion experts, several key research focus areas pertaining to ash formation and deposition have been identified which relate to biomass cofiring in stoker or grate systems. Biomass combustion experts generally agree that:

- There are serious heat-transfer and corrosion issues with respect to ash deposit formation and deposition in stoker or grate systems.

- Stokers are sensitive to the composition of the fuel in the same way as other boilers.

- There are a variety of general ash-related problems that can plague stoker utilization of biomass, but types of fireside ash issues that can be anticipated are very dependent upon fuels or fuel blends. Fouling and slagging may not even be an issue for some biomass types, whereas corrosion or fine particulate control may be an important concern.

Discussions with Dr. Bryan Jenkins from the University of California-Davis (48), Drs. Ingwald Obernberger and Jonas Dahl from the University of Graz-Austria (49), Dr. Fleming Frandsen from the Technical University of Denmark (50), and Dr. Jacob Kiel from the Energy Research Foundation of the Netherlands (ECN) (51) related that stokers do indeed have serious heattransfer and corrosion issues with respect to ash deposition. In general, as alkali and chlorine concentrations are increased, fouling and corrosion problems increase as well. Actual convective pass heat exchanger or fire-tube boiler fouling is more common for biomass fuels such as straws or grasses that have higher ash contents, along with significant concentrations of chlorine and potassium. The most widely used biomass fuel is wood. It is a well-known fact that wood fuels generally contain lower levels of sulfur, chlorine, and ash, compared to coal and most other biomass types. However, it is also known that severe corrosion of heat exchangers can occur in stokers burning wood. Ash deposition is not only the deposition of sticky or thick layers of insulating material that causes heat exchange problems, but also the deposition of fine particulate or vapor species through thermophoretic forces, vapor nucleation, condensation, chemical reaction, and agglomeration processes. These thin deposit layers can cause serious heat exchanger corrosion. Mitigation of ash deposition or corrosion problems can be proposed after deposit formation mechanisms are understood. In one case, University of Graz engineers proposed the reduction of combustion temperatures in a stoker system using flue gas recirculation in order to initiate sulfation of fly ash particles before the particle entered the convective pass. In situ sulfation of ash in the convective pass was leading to hard-to-remove ash deposits (52).

Discussions with Dr. Steve Benson from Microbeam Technologies Incorporated (53) revealed that managers of stoker systems who fire blends of U.S. subbituminous coals and biomass waste products from the pulp and paper industry have significant problems with the formation of ash clinkers on the grate and deposition on high-temperature refractory surfaces and convective pass surfaces. Based on their experience, they have serious reservations concerning the cofiring of certain biomass types with their baseline coal. Experimental test burns of waste wood from the pulp and paper industry with a baseline Powder River Basin (PRB) coal in a northern Minnesota stoker 
system showed a range of potassium-calcium-aluminosilicate, sulfate, and some phosphate-based ash deposition throughout various temperature regions of the boiler, beginning at the grate and moving through the convective pass. Carbonate-based deposits were identified in the electrostatic precipitators (ESPs) and hoppers. The types of ash deposition encountered were very dependent upon the temperature regime.

Discussions with Norman Hinman from BC International (54) and Paul Wood and Marty McFadden from Ogden Power Pacific, Inc. (55), gave insight into the importance of understanding ash formation and deposition issues that could face stoker systems in California and other western states that would choose to burn forest trimming woods and lignin fuels derived from wood or rice straw (lignin from ethanol production). Contacts all agreed that it cannot be assumed that stokers will perform adequately without any ash formation issues when new fuel types are being utilized in the boiler. Primary issues of concern were grate clinkering if high-silica lignin is used, fineparticle deposition of calcium silicates that could impede heat transfer, fine ash deposition of potassium chlorides that could cause severe corrosion, and the production of greater quantities of fines, which could cause emission violations.

Discussions with Larry Baxter from Brigham Young University (56) reiterated the importance of biomass and coal fuel types for ash issues that can be encountered in stoker systems. His knowledge centered more on the development of $\mathrm{NO}_{\mathrm{x}}$ with various configurations of air and fuel distribution around the grate and less on the complexity of ash interaction mechanisms. System parameters, including the distribution of air above and below the grate system, are critically important both for clinker deposit formation on the grate and ash fouling downstream. Imbalances in $\mathrm{CO}, \mathrm{O}_{2}$, and overall volatile yields can occur as below-grate air causes early drying and devolatilization of fuel, with the resulting gases carried upward and mixed later with above-grate air. This can result in insufficient mixing, significant unburned carbon, and localized reducing. Localized reducing can lead to lower-temperature melting points of ash and grate clinkering and tube fouling. In general, herbaceous biomass will result in more potential problems with respect to corrosion, ash deposition, and processing or feeding the biomass.

In an effort paralleling this project, the Energy \& Environmental Research Center (EERC) has recently completed two projects funded by the U.S. Department of Energy (DOE) National Energy Technology Laboratory (NETL) evaluating the feasibility of cofiring biomass in two stoker-fired boiler systems (57). The first project, entitled "Cofiring of Biomass at the University of North Dakota," involved selection of a biomass fuel, completion of a biomass cofiring combustion test, an evaluation of plant modifications/upgrades required to enable biomass cofiring on a long-term basis, and preparation of an analysis addressing the economics of biomass cofiring (58). Biomass fuel selection was based on a resource assessment within a 100-mile radius of the University of North Dakota (UND). Fuel options identified included wood residues, sunflower hulls, and turkey manure. Sunflower hulls were determined to be the preferred fuel, resulting in combustion tests involving the cofiring of sunflower hulls and subbituminous coal. The maximum sunflower hull cofiring rate was $28 \mathrm{wt} \%$. Results from the combustion tests demonstrated reductions in the emissions of sulfur dioxide and nitrogen species (nominally 15\%), no increase in opacity was observed, and a small increase in boiler efficiency was observed. An assessment of plant modifications/upgrades determined that a nominal investment of $\$ 400,000$ and cofiring of $25 \%$ sunflower hulls would result in a $\$ 100,000$ annual savings in total fuel cost, resulting in a 5-year payback, or $20 \%$ return on investment. 
The second project, entitled "Cofiring Biomass with Lignite Coal," evaluated biomass cofiring with lignite in a small stoker system at the North Dakota State Penitentiary (59). A biomass resource assessment determined municipal wood residue to be the most viable fuel choice, delivered at no cost. Free-delivered fuel resulted from an avoided \$10/ton landfill tipping fee. Fuel characterization and fireside modeling indicated ash clinkering and fouling would be minimal, and experimental combustion tests supported that conclusion. A technical and economic assessment addressing fuelhandling requirements and the addition of an electrical cogeneration capability determined that a 15 to 20 -year return could be realized on a maximum investment of $\$ 1,680,000$. Fuel-handling requirements included bulk storage, general handling, sizing, segregation, and potential biomass drying. Electrical cogeneration and the resulting offset of current electrical costs was the most beneficial economic aspect. Other community economic benefits included avoided landfill burden (taxpayer costs), avoided tipping fees paid by waste generators, and additional employment opportunities at the North Dakota State Penitentiary associated with the biomass cofiring/cogeneration facility.

Project activities and results were documented in monthly status reports and semiannual technical progress reports. This document represents the Final Technical Report and includes a discussion of the project objectives and experimental approach, a description of the bench- and pilotscale experimental systems, and a discussion of results and observations on a task basis. Data are presented in tabular and/or graphical formats, conclusions based on the data are summarized, and recommendations for further work are offered, where warranted.

\subsection{PROJECT OBJECTIVES}

The EERC conducted a project to examine the fundamental issues limiting the use of biomass in small industrial steam/power systems in order to increase the future use of this valuable domestic resource. Specifically, the EERC attempted to elucidate the ash-related problems - grate clinkering and heat exchange surface fouling - associated with cofiring a subbituminous coal (Cordero Rojo subbituminous coal) and two biomass types (wood chips and sunflower hulls) in grate-fired systems.

The goal of the project was to identify the primary ash mechanisms related to grate clinkering and heat exchange surface fouling associated with cofiring coal and biomass in grate-fired systems, leading to future mitigation of these problems. The specific technical objectives of the project were:

- Modification of an existing EERC pilot-scale combustion system to simulate a grate-fired system.

- Verification testing of the simulator.

- Laboratory-scale testing and fuel characterization to determine ash formation and potential fouling mechanisms and to optimize activities in the modified pilot-scale system.

- Pilot-scale testing in the grate-fired system to elucidate ash-related problems during biomass-coal cofiring and offer a range of potential solutions. 
To achieve the project goal and technical objectives and address DOE project requirements, the project scope of work was divided into five tasks. Specific objectives for each task are discussed in the following paragraphs.

\section{Task 1 - Project Management Plan}

The objective of Task 1 was the preparation of a detailed Project Plan and Hazardous Substance Plan. Task 1 was added to the original proposed scope of work as a modification at the request of DOE. Both documents were to be submitted to DOE for review within 60 days of contract initiation, and their respective formats were specified in the contract.

\section{Task 2 - Modification of the Pilot-Scale Combustion System}

The overall objective of Task 2 was to upgrade EERC capabilities as they pertain to the performance of pilot-scale combustion tests involving the firing of biomass or coal-biomass blends. Specific objectives included 1) procurement of equipment to facilitate biomass fuel storage, handling, and preparation; 2) procurement of a new flue gas sample conditioner to support flue gas analyzer operation and upgrade the combustion test facility (CTF) data acquisition system software and hardware; 3 ) procurement of new flue gas analyzers to measure $\mathrm{O}_{2}, \mathrm{CO}, \mathrm{CO}_{2}, \mathrm{SO}_{2}$, and $\mathrm{NO}_{x}$; 4) fuel feed system modifications to facilitate operation of the CTF in a grate-fired configuration; and 5) modification of the $\mathrm{CTF}$ combustor to facilitate its operation in a grate-fired configuration while maintaining its pulverized coal (pc)-firing capability.

\section{Task 3 - Verification Testing of the Simulator}

The overall objective of Task 3 was to shake down and verify the performance of the upgrades made to EERC capabilities prior to the performance of pilot-scale combustion tests in Task 5. Specific objectives included performance verification of 1) the biomass fuel storage, handling, and preparation capabilities; 2) the new flue gas sample conditioner to support flue gas analyzer operation and CTF data acquisition system software and hardware upgrades; 3) new flue gas analyzers to measure $\mathrm{O}_{2}, \mathrm{CO}, \mathrm{CO}_{2}, \mathrm{SO}_{2}$, and $\mathrm{NO}_{x}$; 4) fuel feed system modifications to facilitate operation of the $\mathrm{CTF}$ in a grate-fired configuration; and 5) the modified CTF combustor in a gratefired configuration.

\section{Task 4 - Laboratory-Scale Testing and Fuel Characterization}

The EERC has successfully used bench-scale systems for initial screening studies concerning ash formation and ash deposition mechanisms for a variety of fuels. The overall objective of Task 4 was to conduct laboratory-scale testing and detailed fuel and ash characterization in order to determine ash formation and potential ash deposition mechanisms specific to the cofiring of coalbiomass blends. The data obtained from advanced and conventional fuel analyses were used as input for two predictive models or indices to evaluate fireside performance.

The bench-scale combustion tests, along with the fuel, deposit, and fly ash analysis results, were intended to provide insight into three key areas important to the cofiring of coal-biomass blends: 1) the overall combustion characteristics of the fuels and blends, 2) the characteristics of the inorganic material present in the fuels along with the transformation mechanisms that occur during 
ash formation and deposition, and 3) the effect of coal-biomass blending on the amount and size distribution of very fine particulate generated during combustion.

Task 4 also served to optimize activities in Task 5 using the modified pilot-scale system. The resolution of any ash deposition problems, such as varied blend ratios to minimize deposition, added sootblowers, or alternate methods for stoker operation, were to be addressed as a function of the pilot-scale test results.

\section{Task 5 - Pilot-Scale Testing and Reporting}

The objective of Task 5 was to complete two pilot-scale combustion tests using the CTF in a grate-fired configuration in order to elucidate ash-related problems during coal-biomass cofiring and offer a range of potential solutions. The EERC has successfully used the CTF in a pc-firing configuration to address ash-related problems and other fuel performance issues for a broad range of fuel types (bituminous coal, subbituminous coal, lignite, petcoke, and various blends of some of these fuels) including a few biomass fuels. Activities in Task 5 were proposed because pilot-scale testing has been shown to be an effective approach to identification and resolution of fuel-related performance issues.

Task 5 also included project reporting requirements. Project accomplishments and problems were documented in monthly status reports and semiannual technical progress reports. Project results were compiled in a final technical report represented by this document. A draft final technical report was submitted to the DOE Contracting Officer's Representative (COR) for review and comment prior to issuing the final report. Information transfer activities anticipated included project review meetings with the COR. Additionally, since biomass utilization is a rapidly growing topic, two conference trips were also planned to acquire the latest biomass knowledge and to convey any intermediate results to other researchers. Papers prepared for conferences were submitted to the DOE COR for review and comment prior to their submission to the conference coordinator.

\subsection{TECHNICAL/EXPERIMENTAL APPROACH}

As previously stated, biomass is a distributed resource with high relative transportation costs because of its low bulk density and heating value. As a result, the largest populations of plants in which biomass can be utilized in an effective technical and economical manner are small power/steam production units. These unit types are typically grate- or stoker-fired configurations. Therefore, the EERC based the planned scope of work on coal-biomass cofiring in a grate- or stoker-fired combustion system. The planned scope of work consisted of five tasks. Figure 3 depicts the five tasks and their relationship to each other.

\section{Task 1 - Project Management Plan}

Task 1 was initiated in October 2000 and involved the preparation of a detailed Project Plan, including a Milestone Plan (DOE Form 4600.3) and Milestone Log (DOE Form 4600.3A), for review and approval by the DOE COR as well as a Hazardous Substance Plan. A Project Plan was completed and submitted to the COR for review in November 2000. In December 2000, the COR approved Task 2 activities as detailed in the Project Plan but requested revisions to the Project Plan 
before authorizing other activities. As a result of subsequent discussions and preparation of a revised Project Plan, the entire Project Plan was approved in February 2001. Preparation of the Hazardous Substance Plan was completed in November 2000. Preparation of a Hazardous Waste Report was completed in June 2002. Task 1 activities will not be discussed further in this report.

\section{Task 2 - Modification of Pilot-Scale Combustion System}

The overall objective of Task 2 was to upgrade EERC capabilities as they pertain to the performance of pilot-scale combustion tests involving the firing of biomass or coal-biomass blends. Task 2 was initiated in December 2000 subsequent to the EERC receiving written approval for that portion of the Project Plan. Completion of most Task 2 activities was necessary before any gratefired pilot-scale combustion tests could occur. Specifically, fuel preparation capabilities were addressed as well as modifications to the fuel feed system supporting the EERC's CTF. Modifications to the CTF were necessary in order to facilitate its operation in a grate-fired configuration while maintaining its pc-firing capability. The CTF was selected for this modification because of an extensive existing ash deposition database resulting from the firing of bituminous and subbituminous coal, lignite, petcoke, biomass fuels, and various fuel blends over the past $40+$ years.

In addition to modifications directly to the CTF combustor, upgrades were also made to the flue gas instrumentation and data acquisition systems. The flue gas conditioner and most of the flue gas analyzers supporting the CTF were more than 20 years old. As a result, reliability had deteriorated, maintenance costs were increasing, and spare parts were difficult to obtain if not discontinued. Therefore, the age and condition of the equipment had the potential to

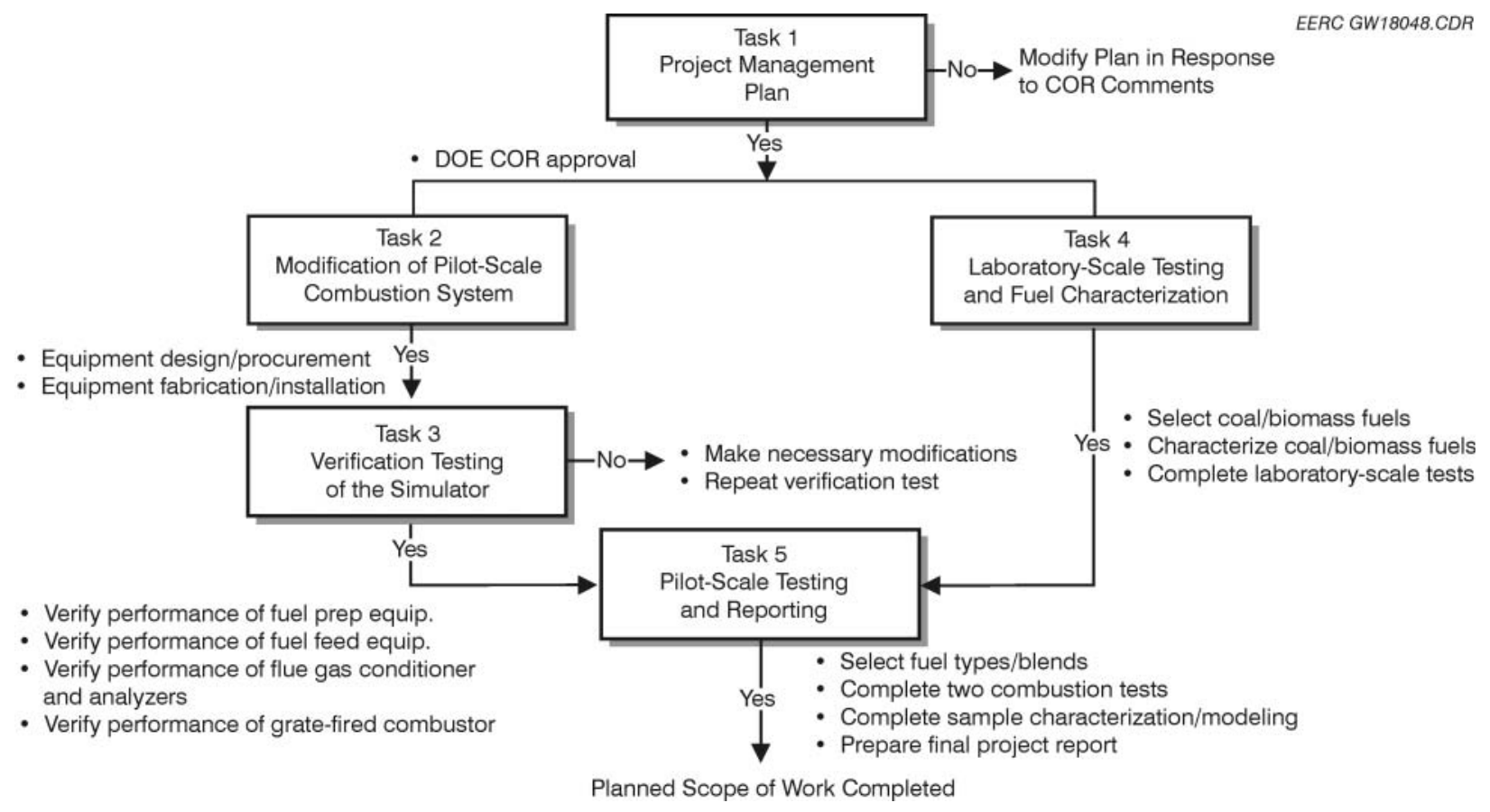

Figure 3. The relationships of the five tasks. 
affect flue gas data availability and quality. Therefore, the EERC elected to replace the flue gas conditioner and five flue gas analyzers.

There were no specific deliverables planned for Task 2. Task 2 accomplishments and problems were documented in monthly status reports and semiannual technical progress reports as well as this Final Technical Report. Detailed equipment specifications and construction drawings related to Task 2 activities are maintained in design files at the EERC and available upon request. Task 2 was completed in September 2002 with final upgrades to the data acquisition system supporting the CTF.

\section{Fuel Storage and Preparation}

The EERC has had storage, handling, and preparation equipment to effectively process and size coal for use in pilot-scale pc-fired systems as well as fluid-bed combustion systems and pilotscale gasification systems for $30+$ years. Selective use and minor adjustments to this equipment permitted the preparation of appropriately sized coal for use in a pilot-scale grate-fired system. However, capabilities were not adequate to store and process biomass. Therefore, the EERC evaluated options to address biomass storage and processing (drying and sizing) requirements in order to meet the needs of this project as well as anticipated future projects involving biomass. Ultimately, the EERC procured and installed new and used equipment items to meet biomass storage and processing requirements.

Biomass storage criteria included a capacity of nominally 9000 to $18,000 \mathrm{~kg}$ (10 to 20 tons), with a "live" bottom component to effectively transfer the material. Storage facilities must effectively protect the biomass from the elements to avoid weathering or significant changes in surface moisture. One option that the EERC planned to consider was the acquisition of a used commercial trailer with a live bottom discharge that could be adequately tarped. A commercial trailer could be used to pick up a quantity of biomass at a commercial site as well as meet on-site storage requirements. In order to operate the live bottom discharge equipment, it would probably be necessary to set up a stationary hydraulic system powered electrically or use an internal combustion engine.

Fuel preparation had to address two potential requirements: 1) the need to dry a given quantity of biomass and 2) the need to properly size the biomass for a given combustion or gasification system. The need to dry a given biomass in support of this project was believed to be a low priority. However, options were considered where a surface moisture drying capability could be incorporated into the general biomass storage/transfer capabilities.

Proper fuel sizing was the highest priority with respect to fuel preparation for this project. However, acquisition of multiple pieces of equipment to address all aspects of fuel sizing were not necessary. The EERC can request permission to make use of a commercial wood chipper that is owned and operated by the city of Grand Forks. Also, a local business has a tub grinder available that the EERC can utilize for a fee. Therefore, the EERC's primary objective for acquisition of fuelsizing equipment addressed adequate capacity (227 to $454 \mathrm{~kg} / \mathrm{hr}$, or 500 to $1000 \mathrm{lb} / \mathrm{hr}$ ) and size reduction capabilities to specifically match fuel size requirements for existing pilot-scale systems. To address this issue, the EERC developed an equipment specification addressing size reduction and capacity requirements and reviewed the information with potential equipment suppliers. Final 
equipment selection was based on anticipated equipment performance, based on EERC experience, as well as cost.

\section{Fuel Feed System}

An existing coal feeder used to support the operation of the CTF in a pc-firing configuration is relatively new. However, it would not be an appropriate option for feeding fuel sized for use in a grate- or stoker-fired system. Therefore, a new feed system was necessary to handle the fuel particle size and simultaneous feeding of coal and biomass that would be required to support operation of the CTF for this project. The EERC had to determine how best to approach cofiring coal and biomass in the CTF. In any event, the purchase of a new feeder was not anticipated. EERC personnel expected to purchase and fabricate parts to assemble an appropriate fuel feed system.

The most significant technical question to be answered was whether or not coal-biomass cofiring could be accomplished using a single feeder delivering a premixed fuel or whether the use of two feeders would be required to achieve acceptable flexibility and performance. With separate feeders the coal-biomass feed ratio would be determined as a function of individual feeder operation. Key performance criteria for the fuel feed system were hopper capacity, mass feed rate range, appropriate fuel particle size, and feed rate stability. Hopper capacity was important to avoid frequent refill cycles. A potential range of mass feed rates was addressed to accommodate variable fuel heating value. Appropriate fuel particle size would be a critical aspect of successfully cofiring coal-biomass in the CTF in a grate-fired configuration. Therefore, the fuel feed system must be able to deliver a sized fuel without measurably altering the particle size. Finally, in order for the combustion system to operate properly, the fuel feed rate must be reasonably stable and uniform.

\section{Pilot-Scale Combustor}

The EERC has several pilot-scale systems to simulate pc firing. These systems have been used to study coal (bituminous, subbituminous, and lignite), petcoke, biomass, and various fuel blends. A significant limitation of EERC capabilities was the absence of a system to effectively simulate grate firing, a capability necessary to understand and identify opportunities to mitigate problems in full-scale stoker facilities. Because of the extensive fuel performance and ash deposition database that had already been developed using the CTF, the EERC determined that this pilot-scale combustion system was the best choice for modification to facilitate grate firing. The CTF is an upfired reactor (approximately $32 \mathrm{~kg} / \mathrm{hr}$, or $70 \mathrm{lb} \mathrm{coal} / \mathrm{hr}$ ) that contains an existing fouling probe bank to simulate convective surfaces and a particulate control system that permits the use of either an ESP or a pulse-jet fabric filter. However, the modifications made will also permit continued use of the pilot-scale combustion system in a pc-firing configuration. Design criteria for the modified system included grate size, approach to fuel feed, undergrate versus overfire air distribution, combustion air preheat, residence time of ash on the grate, time and temperature history of entrained ash, flue gas constituents, and conversion efficiency. The approach to system start-up was also a critical criterion in the design, since the grate-fired system configuration was expected to require a different approach than the conventional heatup on natural gas for pc-fired system operation.

Modifications to the EERC's CTF were designed to best simulate existing industrial systems. The initial design strategy anticipated utilizing a rotating grate system with an air distribution plenum. This approach anticipated using existing ports for overbed fuel feeding as well as existing 
tertiary air ports for overfire air. Materials required to complete the modification were anticipated to include carbon steel, stainless steel, insulating and high-density refractory, and a mechanical drive mechanism to rotate the grate. However, EERC personnel ultimately elected to use a fixed-grate design the details of which are discussed later in this report.

\section{Flue Gas Conditioner}

The EERC planned to purchase a new flue gas conditioner to support the operation of flue gas analyzers used to monitor flue gas composition during CTF combustion tests. Commercially available flue gas-conditioning equipment was evaluated. However, the EERC ultimately solesourced this acquisition based on the purchase of similar equipment in recent years in support of other EERC projects. As a result, a sole-source justification was prepared in accordance with EERC and UND procurement policies.

\section{Flue Gas Analyzers}

The EERC planned to purchase new flue gas analyzers to monitor flue gas composition during CTF combustion tests. Specific analyzers were purchased to measure $\mathrm{O}_{2}, \mathrm{CO}, \mathrm{CO}_{2}, \mathrm{SO}_{2}$, and $\mathrm{NO}_{\mathrm{x}}$ concentrations in the flue gas. Commercially available flue gas analyzers were evaluated. This procurement could have involved purchases from as many as five separate instrument suppliers or as few as two. However, the EERC anticipated sole-sourcing some of these analyzers based on the purchase of similar equipment in recent years in support of other EERC projects. Sole-source justifications were prepared as necessary in accordance with EERC and UND procurement policies. In addition, upgrades were also made to the data acquisition system supporting the CTF.

\section{Task 3 - Verification Testing of the Simulator}

The overall objective of Task 3 was to shake down and verify the performance of the upgrades made to EERC capabilities prior to the performance of pilot-scale combustion tests in Task 5. Task 3 began in July 2001, once installation of the new flue gas sample conditioner and analyzers was completed. Task 3 continued on an intermittent basis during subsequent months as various aspects of Task 2 were completed. Verification of the modified pilot-scale combustion system began in December 2001, following assembly of the pilot-scale grate-fired system components, and refractory curing was completed.

Verification tests addressed the performance of the fuel preparation equipment using biomass as well as the performance of the CTF fuel feed system using coal and biomass. CTF combustion system verification tests were conducted using a subbituminous coal selected for use in Task 5 , similar to fuels previously fired in the CTF in a pc-firing configuration. This permitted data correlation to the existing database. The final verification test involved cofiring a coal-biomass blend selected for use in Task 5. Task 3 was completed in January 2002.

No specific deliverables were planned for Task 3. Task 3 accomplishments and problems were documented in monthly status reports and semiannual technical progress reports as well as this Final Technical Report. All the process data and any analyses completed in support of this task are summarized in a tabular or graphical format later in this document. 


\section{Fuel Storage and Preparation}

No specific experimental matrix was planned to verify the performance of the fuel storage and preparation capabilities acquired. Rather, the performance of the biomass storage and preparation capabilities was evaluated as a function of acquiring and processing fuel in support of the shakedown/verification tests planned for the CTF operating in a grate-fired configuration. Specific performance criteria addressed the 1) reliable performance of the live bottom material transfer capability for moving material from storage to processing equipment, 2) capacity of the fuel-sizing equipment (227 to $454 \mathrm{~kg} / \mathrm{hr}$, or 500 to $1000 \mathrm{lb} / \mathrm{hr}$ ), and 3) ability of the sizing equipment to meet fuel size specifications established for the CTF grate-fired configuration for a specific fuel. Based on observed performance and available project resources, modifications to the fuel storage and processing equipment were made as appropriate.

\section{Flue Gas Conditioner}

No specific experimental matrix was planned to verify the performance of the flue gas conditioner. Vendor specifications concerning power settings and gas flow rates were verified upon installation. In addition, certified calibration gases were allowed to flow through the flue gas conditioner to the flue gas analyzers to check flue gas conditioner performance as well as ensure that sample line connections were tight and there were no leaks. Final verification of the performance of the flue gas sample conditioner occurred as a function of its operation in support of other projects using the CTF in a pc-fired configuration and the shakedown/verification tests conducted with the CTF operating in a grate-fired configuration. Specific performance criteria addressed 1) reliable continuous operation and 2) protection of downstream flue gas analyzers from condensed moisture and fine particulate.

\section{Flue Gas Analyzers}

No specific experimental matrix was planned to verify the performance of the flue gas analyzers purchased. Vendor specifications concerning power settings, gas flow rates, and measurement linearity were verified upon installation. A nitrogen zero gas and certified calibration gases were used to verify the measurement performance of each instrument. This effort ensured that sample line connections were tight and there were no leaks. Final verification of the performance of the flue gas analyzers occurred as a function of their operation in support of other projects using the $\mathrm{CTF}$ in a pc-fired configuration and the shakedown/verification tests completed for the CTF operating in a grate-fired configuration. Specific performance criteria addressed 1) reliable continuous operation, 2) zero and span drift within manufacturer specifications, and 3) linear accuracy within manufacturer specifications. Upgrades to the data acquisition system were verified in terms of consistent input/output values and data retrieval.

\section{Fuel Feed System}

No specific experimental matrix was planned to verify the performance of the modified fuel feed system. Key performance criteria for the fuel feed system were hopper capacity, mass feed rate range, appropriate fuel particle size, and feed rate stability. Final verification of these performance

criteria occurred as a function of feed system operation in support of the shakedown/verification 
tests completed for the CTF operating in a grate-fired configuration. Based on observed performance and available project resources, modifications to the fuel feed system were made as appropriate.

\section{Pilot-Scale Combustor}

The EERC's CTF was modified to simulate a grate-fired system. The pilot-scale grate-fired simulator was subjected to shakedown/verification testing to ensure the modified system operated as intended and its relevance to full-scale systems. Two single-day combustion tests were completed with firing rate controlled to achieve a minimum furnace exit temperature of $983^{\circ} \mathrm{C}\left(1800^{\circ} \mathrm{F}\right)$ at nominally $20 \%$ excess air on a volume basis. Fuel was selected for shakedown/verification testing based on the EERC's pc-fired experience with the CTF and existing database, knowledge of fullscale grate-fired system performance, and Task 4 results. Data comparisons included grate ash properties, fly ash properties, and flue gas properties as they pertain to fuel combustion efficiency. Ash samples were analyzed for carbon content. Adjustments were made to the system as a result of shakedown test observations. It was assumed that the shakedown/verification data would be beneficial to the overall goal of the project in elucidating ash problems. Therefore, detailed sample analyses and gas-phase particulate sampling were completed for this task. However, no specific modeling activities were planned in support of this task. Successful completion of Task 3 was necessary before the experimental phase of Task 5 could begin.

\section{Task 4 - Laboratory-Scale Testing and Fuel Characterization}

The overall objective of Task 4 was to complete laboratory-scale testing and fuel characterization in order to determine ash formation and potential ash deposition mechanisms. Task 4 began in February 2001, following receipt of written approval of the revised Project Plan. Completion of Task 4 was necessary before any grate-fired pilot-scale combustion tests could occur in order to cost-effectively screen candidate fuels and fuel blends. Fuel selection considered current commercial utilization of fuel blends as well as ongoing feasibility studies at the EERC investigating opportunities for biomass cofiring in existing grate-fired units. Final fuel selection and the supporting rationale were reviewed with the DOE COR prior to proceeding with fuel acquisition. Information acquired as a result of Task 4 activities was the basis for fuel selection in Task 5 and assisted in the definition of key combustion and ash behavior issues to monitor during the pilot-scale combustion tests. Experimental activities and analytical work were completed in September 2001, with a draft report submitted to the DOE NETL COR for review. Task 4 was completed in January 2002 with the preparation of a final Task 4 report which is included as part of this Final Technical Report.

Activities in Task 4 were proposed because laboratory-scale testing can be carried out in the EERC's conversion and environmental process simulator (CEPS) at a relatively low cost, allowing for the testing of more variables such as biomass fuel type, blend level, etc. In addition, the EERC has had great success in using smaller systems such as the CEPS for initial screening studies. Although the CEPS is not a grate-fired system, the particulate and gases produced during combustion should resemble the entrained particulate and gases that are released from the grate in stoker systems. Ash deposits, fly ash, and flue gas constituents have been produced and studied for combustion of waste wood, hybrid poplar (wood), wheat straw, alfalfa stems, rice straw lignin, and wheat straw board. Combustion tests with various blends of these biomass fuels with high- and lowrank coals have been conducted as well (43-44). Since the CEPS is not an exact replica of any full- 
scale combustion system, the research studies to date have focused on the fundamental aspects of ash formation and deposition and flue gas constituent concentrations. The CEPS is a versatile system, and combustion test parameters were selected to mimic as closely as possible the types of ash formation and deposition that could occur in a grate-fired system.

To identify the components leading to grate clinkering and ash fouling in a blend, it is essential to first understand the properties of the parent fuels. One representative coal sample and two biomass fuels were selected for analysis and combustion testing. The coal is representative of common commercial use in regions where the selected biomass types are available. The coal and biomass fuels were selected for availability and either current use or the likelihood of future use in commercial applications. Final fuel selection as well as the rationale used in the fuel selection process were reviewed with the DOE COR.

Fuel characterization and laboratory-scale combustion testing using the CEPS were performed on coal and biomass parent fuels and on coal-biomass blends to define key combustion and ash behavior issues to monitor during pilot-scale combustion testing. The CEPS was designed to nominally topfire $2 \mathrm{~kg} / \mathrm{hr}(4.4 \mathrm{lb} / \mathrm{hr})$ of pulverized fuels, with a nominal heat input of $42,200 \mathrm{~kJ} / \mathrm{hr}$ $(40,000 \mathrm{Btu} / \mathrm{hr})$ and an oxygen content of $4 \%$ in the flue gas. Other solid or liquid fuels can be utilized with slight system modifications. The system is designed to simulate the time-temperature history of fuel combustion in a full-scale system using realistic particle residence times before deposition, excess air concentrations, gas temperatures, and deposit surface temperatures. Access to the inside of the combustor is available at a number of locations in the radiant zone for combustion gas analysis, observation, extractive sampling, and insertion of probes to obtain slagging and fouling deposits.

The CEPS system was configured to best simulate vapor and fly ash formation, interaction, and deposition. Deposition focused primarily on fouling deposits, similar to what could occur on heat exchanger surfaces in a grate-fired system. Bulk fly ash and predicted bulk fly ash properties were used to assess clinker formation and fine particulate issues. A detailed description of the CEPS is presented in Appendix A.

Specific deliverables for Task 4 included 1) mechanisms of fly ash formation for parent fuels and blends of biomass with coal; 2) mechanisms of clinker deposit formation; 3 ) mechanisms of ash fouling deposit formation, including the role of potassium chloride, potassium sulfate, and other akali-rich fine particulate; and 4) a preliminary assessment of potential for particulate control problems due to biomass cofiring. Task 4 accomplishments and problems were documented in monthly status reports. A summary of the experimental work completed, including a discussion of the methodology and equipment employed, and results were included in a semiannual technical progress report as well as this document, the Final Technical Report. Process data and analyses completed in support of this task are summarized in an appropriate tabular or graphical format. Results from the modeling activities are also summarized.

\section{Fuel Selection}

Discussions between EERC scientists and engineers and the DOE COR resulted in several fuels being selected as potential candidates for characterization and combustion testing. The fuel

selection process used is described here. The characteristics of specific biomass and coal fuels that 
render them most useful for this project are discussed first, and then a final summary of fuel selection is given.

\section{Biomass Fuel}

For this project, budget constraints limited fuel selection to two types of biomass and one coal type for cofiring tests. Wood and sunflower hulls were the two biomass types that were pursued as candidate biomass fuels.

Wood biomass is a high-priority biomass for stoker- or grate-fired systems for several reasons. Wood residue as a biomass fuel has the greatest appeal for cofiring studies nationally because of its widespread availability, relatively low cost, higher relative density, lower air toxic emissions, zero net gain of $\mathrm{CO}_{2}$, and subtle ash impacts compared to coal or other biomass types. Wood residues are well dispersed throughout the nation, with tons of waste wood being landfilled or burned every day at tipping fees from $\$ 10-50 /$ ton $(1,47,59)$. Under more stringent regulation, many landfills can no longer burn wood residues and are forced to process wood with tub grinders and bury the material or convert it to compost. Most landfills would rather divert raw tree trunks and branches. The types of wood residues include forest residue, industrial residue, and municipal waste residue. In North Dakota, where trees are scarce, cities of about 40,000 people generate approximately 10,000 tons/yr of wood residue (60).

Wood biomass could consist of clean wood sources such as sawmill residue or pallets, contaminated wood derived from secondary manufacturing processes such as waste from pressed or particle board, demolition wood from older buildings, and tree trimmings or residual forest wood. Some waste woods from manufacturing plants may contain chlorides and nitrogen compounds from glues, which can greatly impact a combustion system. Wood may also contribute additional calcium and potassium to the combustion ash flux, which can impact fouling and slagging, especially when these components are interacting with coal inorganic components.

Another potential biomass type could include agricultural residues such as sunflower hulls. Wood has applications to stoker systems across a larger portion of the United States and sunflower hulls would be available only in central and Midwest U.S. agricultural regions. However, sunflower hulls are similar in properties to other herbaceous biomass crop residues such as wheat straw, alfalfa stems, rice straw, and rice straw hulls; therefore, the information obtained in this project could be extrapolated to these other biomass types.

Sunflower hulls are attractive not only because of their availability but because they have a fairly low ash content (3\%-7\%), with typical biomass inorganic concentrations (potassium, phosphorus, amorphous silica, and calcium) that could provide fundamental study of ash deposition and particulate formation $(38,39)$. Other agricultural residues such as wheat and rice straws, almond shells, lignin derivatives, and bagasse have been used elsewhere, and still other types may be available in certain U.S. regions but would have to be studied in follow-on projects.

\section{Coal}

Table 3 lists candidate coals and parameters that characterize the coals. A brief description of potential ash formation and deposition issues that can be studied with these coal types is given. 


\begin{tabular}{lcccccc}
\hline & & \multicolumn{5}{c}{ Western } \\
Coal: & Beulah & PRB & $\begin{array}{c}\text { Illinois } \\
\text { No. } 6\end{array}$ & $\begin{array}{c}\text { Kentucky } \\
\text { No. } 9\end{array}$ & Blacksville & $\begin{array}{c}\text { Pittsburgh } \\
\text { No. 8 }\end{array}$ \\
Rank: & Lig. & Sub. & Bit. & Bit. & Bit. & Bit. \\
\hline $\mathrm{Cl}, \mathrm{ppm}$ & $<50$ & $<50$ & 1200 & 400 & 760 & 850 \\
$\mathrm{~S}, \mathrm{wt} \%$ coal & 1.5 & 0.52 & 2.9 & 3.1 & 2 & 3.3 \\
$\mathrm{CaO}, \mathrm{wt} \%$ ash & 14.1 & 23.5 & 2.5 & 1.7 & 5.5 & 1 \\
$\mathrm{Fe}_{2} \mathrm{O}_{3}$ & 7.9 & 6.67 & 16 & 23.6 & 17.3 & 25 \\
$\mathrm{~K}_{2} \mathrm{O}$ & 0.6 & 0.32 & 2.5 & 2.2 & 1.6 & 1.8 \\
$\mathrm{Na}_{2} \mathrm{O}$ & 5.6 & 1.26 & 0.84 & 0.4 & 0.9 & 0.43 \\
\hline
\end{tabular}

\section{Low-Rank Coal (including PRB and North Dakota Beulah lignite)}

Low-rank coals have not been studied to any great degree with respect to cofiring with biomass for power generation, and for this reason, low-rank coal was a fairly high-priority candidate. Both a North Dakota lignite and a PRB coal would give excellent opportunities to study 1) biomass cofiring that will apply to several real-world systems in North Dakota, Minnesota, and other regions of the country where PRB coal is utilized and 2) sodium, calcium, magnesium and, possibly, phosphorus ash deposit formation and interaction with coal-derived silicate components in higher-temperature regions of the boiler or with coal-derived sulfur to form sulfates, with biomass-derived chlorine to form chlorides in the cooler region of the boiler. The formation of abundant alkali-rich fly ash may change the characteristics of fine particulate that the boiler is used to, which could cause particulate collection problems.

\section{Illinois No. 6 or No. 5 Bituminous Coal}

Illinois No. 6 and No. 5 were acceptable coal candidates because several eastern U.S. utilities burn this Illinois Basin coal, and it has been used in a cofiring mode with biomass at Tennessee Valley Authority (TVA). Experimental biomass cofiring projects at the EERC have previously incorporated this coal, which would add to the experimental database (2-3). Illinois No. 6 is typically high in chlorine and sulfur, and therefore, the study of the formation of fine particles and condensible chloride or sulfate species of potassium and calcium derived from biomass would be possible. High iron contents of Illinois No. 6 in combination with higher relative alkali from certain biomass may produce clinkering deposition that is worth studying as well.

\section{Western Kentucky No. 9 Bituminous Coal}

Western Kentucky No. 9 bituminous coal was another Illinois Basin coal considered for study because of its broad usage among eastern utilities and testing experience at the EERC on large pilotscale equipment. This coal has the propensity to form sulfates of potassium and other alkalies, which 
may have implications for low-temperature ash deposition and fine particulate generation. It is lower in chlorine and iron compared to the Illinois No. 6.

\section{Blacksville Bituminous Coal}

Another coal that has had considerable experimental study at the EERC and abroad, but not necessarily with regard to biomass, is the Blacksville bituminous coal from the Appalachian Basin. This coal is higher in calcium compared to the bituminous coals described previously and is moderately high in chlorine and sulfur; therefore, it was a good candidate for studying potential lower-temperature sulfate deposition or fine particulate generation.

Pittsburgh No. 8

The Pittsburgh No. 8 Appalachian Basin bituminous coal also has had extensive real-world commercial use, in addition to experience in the laboratory (1). This coal is fairly high in chlorine and very high in sulfur and iron. Extensive fine particulate in the form of sulfates and chlorides of possibly potassium and other biomass-derived alkali could be anticipated during cofiring. The high iron in this coal could lead to potential localized clinkering if the right combinations of biomass inorganics were incorporated in localized reducing environments.

Based on the discussion in the preceding paragraphs, the biomass types and coals suggested, in priority of importance for testing in this program, and the reasons for their selection are as follows.

\section{Clean Waste Wood Biomass}

- Applicable across the United States because of availability, cost, flue gas emission benefits, and ease of incorporation into stokers.

- Fine particulate and ash fouling and clinkering issues, possibly due to wood-derived calcium and potassium to the combustion ash flux.

\section{Sunflower Hulls}

- Available in central and Midwest U.S. agricultural regions, with properties similar to other herbaceous biomass types.

- Moderate ash content with significant concentrations of potassium, phosphorus, amorphous silica, and calcium that could provide fundamental study of ash deposition and particulate formation and interaction with coal elements.

- Regional commercial applications.

\section{Powder River Basin Coal}

- $\quad$ Significant and growing use across the United States. 
- Significant alkali for interaction with biomass inorganic constituents.

- Direct regional application to full-scale commercial units.

\section{North Dakota Lignite}

- Direct application to DOE-funded stoker retrofit project with the North Dakota State Penitentiary.

- Lignite alkali and sulfur interaction with biomass potassium and calcium for fundamental ash formation and deposition studies.

\section{Eastern U.S. Bituminous Coal}

- Extensive use with U.S. utilities and availability for stokers.

- Some experimental biomass cofiring experience.

- Typically high in chlorine and sulfur; therefore, the study of the formation of fine particles and condensible chloride or sulfate species of potassium and calcium derived from biomass may be possible. High iron contents may be good for clinkering studies.

\section{Fuel Characterization}

To identify the components leading to grate clinkering and ash fouling in a blend, it is essential to first understand the properties of the parent fuels. All fuels were analyzed to fully characterize the inorganic and ash-forming constituents using conventional and advanced techniques. The three parent fuels were submitted for analysis of particle size, bulk density, heating value, proximate-ultimate analysis, chlorine, and major ash chemistry (i.e., $\mathrm{SiO}_{2}, \mathrm{Fe}_{2} \mathrm{O}_{3}$, etc.). Advanced fuel analysis using chemical fractionation (CHF) and computer-controlled scanning electron microscopy (CCSEM) was also performed. These latter analysis techniques give a detailed picture of the mineralogy and chemistry of the inorganic fuel constituents not possible with conventional analysis.

CHF analysis is a series of selective chemical leachings that quantifies organically bound inorganics and minerals that are less than $1 \mu \mathrm{m}$ in size. Organically bound inorganics are common in low-rank fuels and biomass and may comprise the bulk of the inorganic material less than $1 \mu \mathrm{m}$ in size. Low-rank subbituminous and lignite coals act as ion-exchange materials, with alkali and alkaline-earth elements such as $\mathrm{Ca}^{++}, \mathrm{Na}^{+}$, and $\mathrm{K}^{+}$attaching to carboxylic acid groups in the fuel. $\mathrm{Up}$ to half the calcium and all of the sodium and potassium present in the fuel ash may be bound in this way. When the fuel is burned, these highly dispersed elements have a high propensity to interact with other minerals present as well as form very fine ash. Biomass often shows very significant concentrations of organically bound potassium.

CCSEM analysis is used to determine the size and composition of the mineral grains in a fuel that are greater than $1 \mu \mathrm{m}$ in diameter, along with determining the association of the mineral grains, i.e., whether mineral grains are embedded in the fuel particles (included minerals) or are free grains 
not attached to the fuel particles (excluded minerals). This association of mineral grains has a significant effect on the formation of fly ash and ash deposits, with included mineral grains much more likely to combine with each other than are the free excluded mineral grains.

\section{Predictive Modeling}

The data obtained from the advanced and conventional fuel analyses were used as input for two predictive models or indices to evaluate fireside performance. The model termed Predictive Coal Quality Effects Screening Tool, or PCQUEST, was developed at the EERC and is designed to determine combustion performance indices, including the potential for furnace wall slagging and convective pass fouling of various fuels. This model utilizes CCSEM and CHF data as well as system information to make system-specific predictions. Given the analyses of the parent fuels, the PCQUEST model has the ability to perform calculations for two- or three-component blends of these fuels. The high-temperature fouling, low-temperature fouling, and slagging indices may be useful in assessing ash deposition potential for various blend levels of biomass and coal. The indices are on a scale of $0-100$, with $0-33$ being low, 34-66 being medium, and 67-100 being a high or severe value. PCQUEST is used to evaluate the relative performance of fuels and is most effective when compared to fuels of known fireside performance.

The Facility for the Analysis of Chemical Thermodynamics (FACT) model is an integrated thermodynamic database coupled to programs developed to calculate multicomponent multiphase equilibria based on a minimization of Gibbs' free energy. The code is used for assessing fuel quality effects on ash behavior in a boiler based on predictions of molar fractions (partial pressures) of all gas, liquid, and solid stable components. Output from FACT includes quantities, compositions, and viscosities of liquid and solid mineral phases; therefore, the code works well for predicting the behavior of fuel ash, including biomass-derived ash for different boiler temperature regimes. This model is especially useful for extrapolating to different temperature regions in a boiler to assess potential slag or fouling deposit formation, and it is also useful for performing blend evaluations.

The calculations predict the percentage of liquid phases present as a function of temperature, with viscosities for the liquid-phase material as a function of temperature subsequently calculated using a modified form of the Urbain equation. Both the viscosity and the amount of liquid phases present are important in predicting the amount of slagging and fouling that can occur. The PCQUEST and FACT models complement each other, together providing a reasonable prediction of relative fireside performance. The advantage of PCQUEST is that ash partitioning between bottom ash and fly ash is accounted for in the model algorithms, while FACT uses the bulk fuel ash composition. However, FACT provides predictions as a function of temperature, while the PCQUEST model implicitly assumes a "typical" boiler with a furnace exit gas temperature of approximately $1205^{\circ} \mathrm{C}\left(2200^{\circ} \mathrm{F}\right)$.

\section{Laboratory-Scale Combustion Tests}

A full suite of ash formation and deposition data were generated on the parent fuels and on the blends to compare combustion performance. Ash deposits and fly ash were generated simultaneously during CEPS testing. Ash deposits were collected in a temperature regime of the CEPS furnace that simulates the convective pass region of full-scale boilers $\left(1000^{\circ}-1300^{\circ} \mathrm{C}\right.$, or $1832^{\circ}-2372^{\circ} \mathrm{F}$ ) to examine silicate and combined silicate-sulfate deposition. These simulations also 
attempted to parallel combustion and ash deposition parameters in the modified CTF for aiding in the selection of test parameters in Task 5. The formation of convective pass deposits is the most critical type of ash deposition that may be encountered. The deposits were collected on ash deposition probes equipped with removable coupons. The adhesion strength of the deposits to the steel deposit collection probe surface was estimated, and the overall crushing strength of the deposits was determined. The growth rate of the deposits in a fouling environment for each combustion test was measured.

Deposit accumulations on the coupons were analyzed for porosity and deposit composition using scanning electron microscopy (SEM) morphological examination and scanning electron microscopy point count (SEMPC) analysis, with the presence of major mineral phases, confirmed by $\mathrm{x}$-ray diffraction (XRD) analysis. Deposit ash components that are prime contributors to initiating or exacerbating ash deposit accumulation and growth were determined. In addition to the three tests described above, the amount and viscosity of bonding material in the main parts of the deposits were estimated using SEM techniques. It is the sintering action of low-viscosity liquid phases in the deposit that causes hard-to-remove deposits to form. Particular focus was on the fundamental interaction of higher calcium, potassium, and phytolith silicon from the biomass with calcium-sodium-aluminosilicate-rich phases derived from the coal.

The fundamental interaction between condensed vapor phases from biomass and silicate material derived from coal and the resulting impact on inner deposit layer formation and ash deposit viscosity for coal-biomass blends were investigated. The role of other potentially key elements such as phosphorus or sodium in inner deposit layers was examined.

During the combustion tests, the ash particle-size distribution was monitored using an on-line aerodynamic particle sizer (APS) with a measurement range of $0.2-30 \mu \mathrm{m}$ and a scanning mobility particle sizer (SMPS) with a measurement range of 0.013-0.8 $\mu \mathrm{m}$. Together, the APS and SMPS provide a complete picture of the fly ash particle-size distribution, including the very fine aerosols characteristically resulting from biomass combustion.

Fly ash particle-size and composition distribution in the CEPS baghouse ash were examined, with particular attention to sulfates and chlorides of alkali and fine silica using CCSEM analysis along with Malvern particle-size analysis. The interaction of silicates from the coal with organically bound $\mathrm{Ca}$ and $\mathrm{K}$ from the biomass was studied, along with the formation of small particulate from vapor condensation of chlorides, sulfates, and phosphates.

Predictive modeling using the FACT code was done based on the deposit composition in order to make indirect links between phase formation in the deposits and deposit tenacity, and especially to assess high-temperature slagging deposit formation, as no slagging deposits were produced during the CEPS testing. FACT code modeling was specifically used to predict solid silicate materials and vapor components and liquid-phase viscosity for the deposits.

These laboratory-scale combustion tests, along with the fuel characterization and modeling results, provided insight into five key areas important to the cofiring of coal-biomass blends: 1) the overall combustion characteristics of the fuels and blends, 2) the characteristics of the inorganic material present in the fuels along with the transformation mechanisms that occur during ash formation and deposition, 3 ) the effect of coal-biomass blending on the amount and size distribution 
of very fine particulate generated during combustion, 4) the fouling and clinkering potential, and 5) potential means to predict or assess coal-biomass blend combustion characteristics in the future.

\section{Task 5 - Pilot-Scale Testing and Reporting}

The objective of Task 5 was to complete two pilot-scale combustion tests using the CTF in a grate-fired configuration in order to elucidate ash-related problems during coal-biomass cofiring and offer a range of potential solutions. The EERC has successfully used the CTF in a pc-firing configuration to address ash-related problems and other fuel performance issues for a broad range of fuel types (bituminous coal, subbituminous coal, lignite, petcoke, and various blends of some of these fuels) including a few biomass fuels. Activities in Task 5 were proposed because pilot-scale testing has been shown to be an effective approach to identification and resolution of fuel-related performance issues. In addition, Task 5 included project reporting requirements.

Task 5 was initiated in November 2000 with the preparation of the October monthly status report. Completion of Task 5 will occur as a function of the EERC's submission of the Final Technical Report (this document) to DOE. Fuel selection and blend ratios for Task 5 were based on Task 4 results. Task 5 experimental activities began in January 2002, following completion of Task 3 , and were completed in February 2002. Two pilot-scale coal-biomass cofiring combustion tests were completed using the modified $\mathrm{CTF}$ in a grate-fired configuration. Sample analyses and data evaluation continued into April 2002. The primary deliverable for this task is information concerning specific ash behavior for cofiring biomass with coal. Mechanisms of fouling and the degree of fouling are identified. This information will be useful for many small stoker- or grate-fired energy system operations that are considering biomass cofiring.

\section{Pilot-Scale Combustion Tests}

Based on the results of the Task 4 laboratory-scale work, combustion tests were performed in the pilot-scale CTF grate-fired system. Two separate tests were planned, with each test including a full suite of gas sampling $\left(\mathrm{O}_{2}, \mathrm{CO}, \mathrm{CO}_{2}, \mathrm{SO}_{2}\right.$, and $\left.\mathrm{NO}_{\mathrm{x}}\right)$ and analyses, fuel sampling and analyses, fly ash sampling and analyses, and deposit sampling and analyses similar to those performed in the laboratory-scale testing. It was also assumed that a significant amount of the verification data from Task 3 would be beneficial to the overall goal of the project in elucidating ash problems. The modeling methodology described in Task 4 was also applied in Task 5. Each of the two biomass fuels selected were blended with coal at a level determined from the laboratory-scale testing. A detailed test plan for the two pilot-scale combustion tests was developed and submitted to the project COR for review and comment after the laboratory-scale tests were completed.

All of the results for the pilot-scale grate-fired system were evaluated and compared to existing data for pc-fired simulation and existing full-scale data. In addition to the technical assessment, an economic assessment was also performed based on separate ongoing activities and past projects at the EERC. Mitigation measures were to be proposed if severe ash deposition was observed, although testing of mitigation measures was not within the scope of this project. 


\section{Project Reporting Requirements}

Project accomplishments and problems were documented in monthly status reports, and project progress was addressed in quarterly updates to the milestone plan (DOE Form 4600.3) and milestone $\log$ (DOE Form 4600.3A). Semiannual technical progress reports were prepared summarizing the results from each task as the project progressed, with all of the project results summarized in a final technical report. A draft final technical report was submitted to the DOE COR for review and comment prior to issuing this final technical report. An interim and final project review meeting were planned at NETL. Additionally, since biomass utilization is a rapidly growing topic, two conference trips were also planned to acquire the latest biomass knowledge and to convey any intermediate results to other researchers. Papers prepared for these conferences were submitted to the DOE COR for review and comment.

\subsection{RESULTS AND DISCUSSION}

The results from EERC activities in support of this project are documented in this section of the report. As previously stated Task 1 - Project Management Plan activities have been addressed elsewhere in this report and will not be discussed further here. Results are discussed for the following tasks:

Task 2 - Modification of the Pilot-Scale Combustion System

Task 3 - Verification Testing of the Simulator

Task 4 - Laboratory-Scale Testing and Fuel Characterization

Task 5 - Pilot-Scale Testing and Reporting

\section{Task 2 - Modification of the Pilot-Scale Combustion System}

The overall objective of Task 2 was to upgrade EERC capabilities as they pertain to the performance of pilot-scale combustion tests involving the firing of biomass or coal-biomass blends. Specific activities addressed general fuel storage and preparation capabilities, modifications to the fuel feed system supporting the EERC's CTF, modifications to the CTF to facilitate its operation in a grate-fired configuration, and upgrades to the flue gas instrumentation and data acquisition system supporting the CTF.

\section{Fuel Storage and Preparation}

The EERC has had storage, handling, and preparation equipment to effectively process and size coal for use in pilot-scale pc-fired systems as well as fluid-bed combustion systems and pilotscale gasification systems for $30+$ years. Selective use and minor adjustments to this equipment permitted the preparation of appropriately sized coal for use in a pilot-scale grate-fired system. However, capabilities were not adequate to store and process biomass. Therefore, the EERC evaluated options to address biomass storage and processing (drying and sizing) requirements in order to meet the needs of this project as well as anticipated future projects involving biomass. As a result, the EERC procured and installed new and used equipment items to meet biomass storage and processing requirements. 
Existing storage bunkers at the EERC were not appropriate for use with most biomass fuels because they were designed for coal. Because biomass has significantly different flow properties and bulk density, alternative storage options were reviewed. Biomass storage criteria included a capacity of nominally 9000 to $18,000 \mathrm{~kg}$ (10 to 20 tons), with a live bottom capability to effectively transfer the material. To be effective, storage facilities must protect the biomass from the elements to avoid weathering or significant changes in surface moisture. The primary option that the EERC considered was the acquisition of a used over-the-road transport trailer that could be adequately tarped with a live bottom discharge. An over-the-road trailer could be used to pick up a quantity of biomass at a commercial site as well as meet on-site storage requirements. In order to operate the live bottom discharge equipment without tractor hydraulic support, it would be necessary to set up a portable hydraulic system powered electrically or with an internal combustion engine.

After reviewing new and used trailer options with seven retail companies in the area, the EERC determined that a new trailer would cost roughly $\$ 50,000$. The cost of available used trailers ranged from $\$ 29,000$ to $\$ 35,000$ for belt discharge units, and a used walking-floor trailer was $\$ 32,000$. Based on personnel experience, the EERC determined that the most flexible trailer storage option identified was a walking-floor-type trailer that could be tarped/covered. Therefore, EERC efforts focused on finding a used walking-floor-type trailer that could be acquired for less than the $\$ 32,000$ quoted for a 1995 model unit.

As a result of conversations with U.S. Environmental Protection Agency (EPA) personnel in July 2000, the EERC found a used walking-floor semitrailer being offered by the Research Triangle Institute (RTI). The trailer is a 1979 Budd walking-floor trailer (12-m, or 40-ft, tractor trailer) and had been used in support of an EPA biomass demonstration project. The gross load limit for the trailer is $30,900 \mathrm{~kg}$ (34 tons) with a net cargo weight limit of $21,800 \mathrm{~kg}$ ( 24 tons). Nominal capacity on a volumetric basis is $72 \mathrm{~m}^{3}\left(2560 \mathrm{ft}^{3}\right)$. Assuming a material bulk density of $240 \mathrm{~kg} / \mathrm{m}^{3}\left(15 \mathrm{lb} / \mathrm{ft}^{3}\right)$, the capacity of the trailer would be nominally $17,000 \mathrm{~kg}(38,000 \mathrm{lb}$, or 19 tons). After several conversations with RTI and EPA personnel concerning the condition of the trailer and options for relocating it from North Carolina to North Dakota, the EERC initiated procurement actions in order to obtain the used walking-floor semitrailer at a cost of $\$ 7000$. Additional charges for replacement of a tire and transporting the trailer to North Dakota added $\$ 2800$ to the delivered cost. Subsequent to its delivery in December 2001, the EERC had a new roll tarp installed on the trailer to protect its contents from weather conditions at a cost of $\$ 2200$. Therefore, the total cost of the walking-floor semitrailer was $\$ 12,000$. A photograph of the trailer is presented in Figure 4.

In addition to the walking-floor semitrailer, the EERC also elected to purchase an agricultural forage box. The forage box will be used for storage of small quantities of biomass fuel. However, its primary use will be to transfer biomass fuel from storage to processing equipment. After reviewing new and used forage box options with ten retail companies in the area, the EERC determined that a new forage box was the best option based on the poor condition of available used units. After further discussions with forage box dealers and a review of specifications and quotes provided, the EERC elected to purchase a $5.5 \mathrm{~m} / 12,700 \mathrm{~kg}$ (18 ft/14 tons) front-rear combination unload Badger forage box. The combination front-rear unload capability permits the EERC to choose between a controlled discharge of forage box contents through the front cross-conveyor or unloading of the entire contents of the forage box in a short period of time through the rear door. The versatility offered by this arrangement is highly desirable when considering potential materialshandling and processing requirements. 


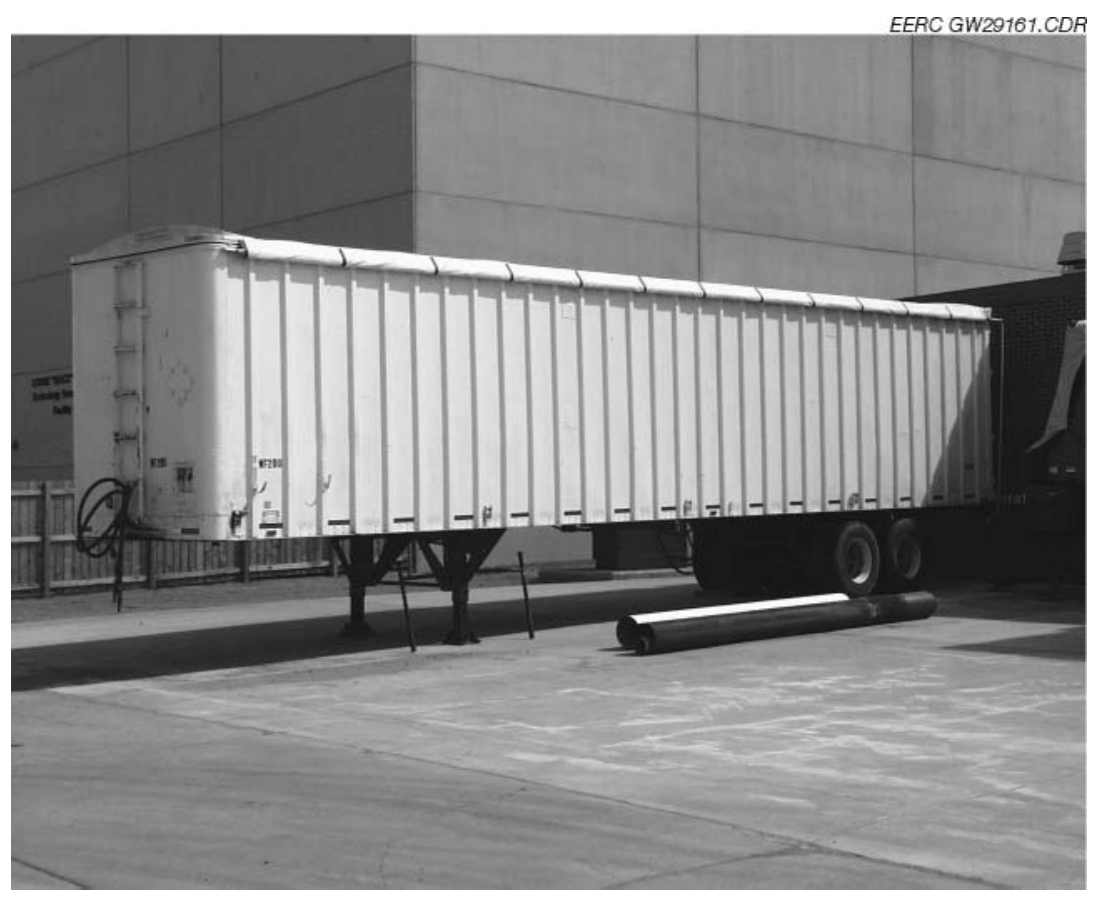

Figure 4. Photograph of walking-floor semitrailer.

Running gear design limits the forage box capacity to $12,700 \mathrm{~kg}$ (14 tons) gross weight, with a net weight limit of $8200 \mathrm{~kg}$ (9 tons). Nominal capacity on a volumetric basis is $23 \mathrm{~m}^{3}\left(800 \mathrm{ft}^{3}\right)$. Assuming a material bulk density of $240 \mathrm{~kg} / \mathrm{m}^{3}\left(15 \mathrm{lb} / \mathrm{ft}^{3}\right)$, the capacity of the trailer would be nominally $5450 \mathrm{~kg}(12,000 \mathrm{lb}$, or 6 tons). The EERC initiated procurement actions in August, and the forage box was delivered in September 2001 at a total cost of nominally $\$ 17,600$. A photograph of the forage box is presented in Figure 5.

In order to properly site and facilitate the use of the walking-floor semitrailer and agricultural forage box, the EERC requested (September 2001) and DOE granted (October 2001) permission to install a concrete pad (nominally 60 by $70 \mathrm{ft}$, or $4200 \mathrm{ft}^{2}$ ). In addition, the concrete pad will be used for air-drying biomass materials with high surface moisture when necessary prior to processing. Since the EERC was able to reduce anticipated expenditures as a result of acquiring several pieces of used equipment, the original equipment budget was adequate to cover the cost of installing the concrete pad prorated to this project $(\$ 15,000)$. Separately, the EERC covered expenses incurred with respect to moving and protecting utilities at the location where the concrete pad was installed using internal funding. The concrete pad was poured in November 2001 and is visible in Figure 4.

In addition to the walking-floor semitrailer obtained from RTI, the EERC obtained other miscellaneous surplus equipment from EPA. A specific item of interest offered as surplus property by EPA was a hydraulic power unit driven by a gasoline engine. The EERC's interest in this piece of equipment stemmed from its potential to operate the hydraulic floor of the walking-floor semitrailer and the cross-conveyor and apron of the agricultural forage box. Typically, hydraulic power to operate the walking-floor semitrailer would be supplied by the semitractor towing the trailer. In the case of the agricultural forage box, a farm/industrial tractor would supply the necessary hydraulic power. Since the EERC does not own either a semitractor or a farm/industrial tractor, an 


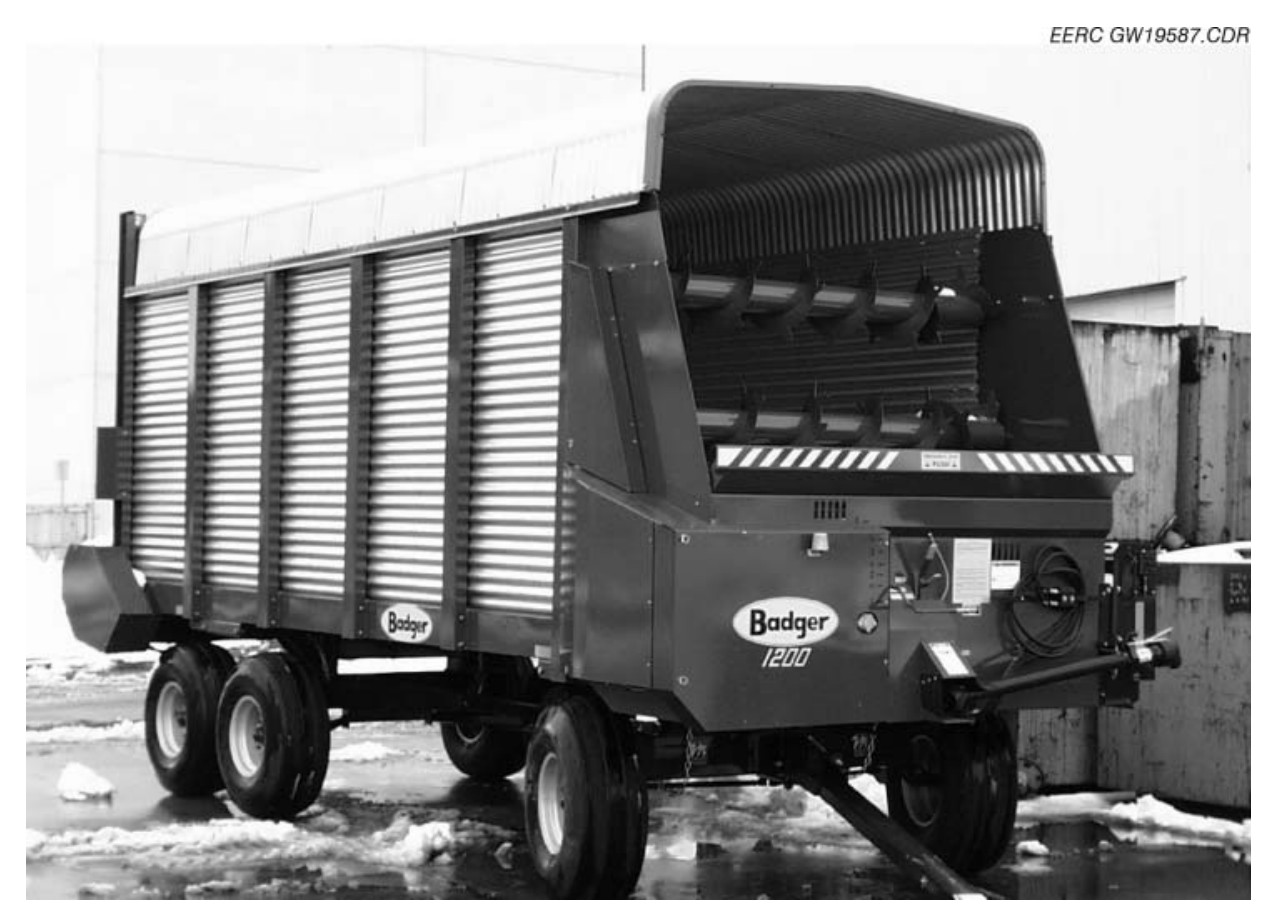

Figure 5. Photograph of agricultural forage box.

alternative hydraulic power source was required. One option was adding a hydraulic pump to an existing EERC skid-steer loader. However, hydraulic fluid capacity would be limited.

In order to assess the potential to use the hydraulic power unit acquired from EPA as surplus property, it was necessary to completely disassemble and clean the unit. The gasoline engine that drives the hydraulic pump required repairs as well as a tune-up. Engine repairs included replacing the fuel tank, throttle assembly, and governor gear. In addition, hydraulic hoses were replaced and hydraulic couplings were installed to match those on the walking-floor semitrailer and agricultural forage box. After completing this effort, the EERC successfully demonstrated that the hydraulic power unit was capable of supporting hydraulic operation of the trailer and forage box. Subsequently, a cart was purchased and the components were mounted on the cart so that the hydraulic power unit could be easily moved to support operation of the trailer and forage box. Work on the hydraulic power unit was completed in January 2002, with component and repair/replacement parts totaling nominally $\$ 1200$. A photograph of the hydraulic power unit is presented in Figure 6.

Fuel preparation had to address two potential requirements: 1) the need to dry a given quantity of biomass and 2) the need to properly size the biomass for a given combustion or gasification system. The need to dry a given biomass in support of this project was believed to be a low priority. However, options were considered where a surface moisture-drying capability could be incorporated into the general biomass storage/transfer capabilities. As a result, surface drying of biomass can be accomplished outdoors, assuming weather conditions are appropriate, by spreading the biomass on the poured concrete pad previously discussed and turning it over periodically to achieve a desired level of air drying. Another option is to continuously transfer the biomass between the walking-floor semitrailer to the agricultural forage box and back to the trailer until the desired 


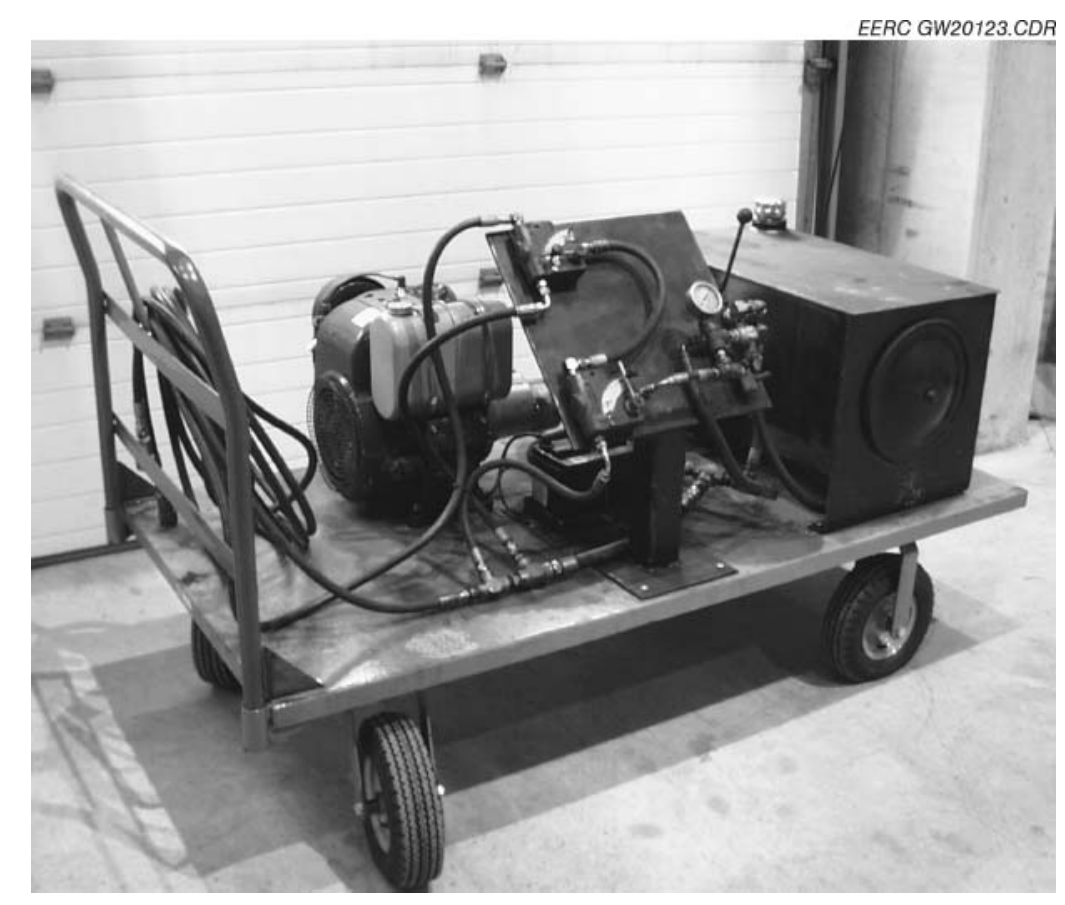

Figure 6. Photograph of hydraulic power unit.

surface moisture is achieved as a result of air drying. In the event of inclement weather, indoor air drying is also an option and will be discussed later.

Proper fuel sizing at reasonable capacity was the highest priority with respect to fuel preparation for this project. However, acquisition of multiple pieces of equipment to address all aspects of fuel sizing was not necessary. An existing rotary crusher and hammer mill can be used for some biomass fuel preparation activities involving small quantities $(45 \mathrm{~kg} / \mathrm{hr}$, or $100 \mathrm{lb} / \mathrm{hr}$ ) for pulverized fuel and some fluid-bed firing. The EERC can request permission to make use of a commercial wood chipper that is owned and operated by the city of Grand Forks. Also, a local business has a tub grinder available that the EERC can utilize for a fee. Therefore, the EERC's primary objective for acquisition of fuel-sizing equipment addressed adequate capacity (227 to $454 \mathrm{~kg} / \mathrm{hr}$, or 500 to $1000 \mathrm{lb} / \mathrm{hr}$ ) and size reduction capabilities to specifically match fuel size requirements for existing pilot-scale combustion and gasification systems. Size reduction requirements included as small as $1.65 \mathrm{~mm} / 1650 \mu \mathrm{m}$ to $0.63 \mathrm{~cm}(10 \mathrm{mesh} / 0.06$ in. to $0.25 \mathrm{in}$.) material for pulverized fuel applications and 0.63 to $5.1 \mathrm{~cm}(0.25$ to $2.0 \mathrm{in}$.) material for fluid-bed and grate-fired applications, depending on the physical properties of the fuel and specific process conditions. To address this issue, the EERC developed an equipment specification addressing the size reduction and capacity requirements previously stated and reviewed the information with potential equipment suppliers. Final equipment selection was based on anticipated equipment performance, derived from vendor information and EERC experience, as well as cost.

As a result of discussions with several potential equipment suppliers, the EERC elected to focus on the acquisition of an appropriately sized hammer mill with multiple screens to affect product size in order to achieve most biomass fuel preparation requirements. After reviewing options concerning new and used equipment, the EERC elected to procure a rebuilt Jacobson hammer mill, 
Model 556DF11. This hammer mill is a quick-change half-screen unit with the capability to discharge product through an outlet blower or gravity chute. Depending on the feed material type and size and desired product size, processing capacity should be 454 to $908 \mathrm{~kg} / \mathrm{hr}$ (1000 to $2000 \mathrm{lb} / \mathrm{hr}$ ). A direct-drive 30-kW (40-hp 220/440-V) 3-phase explosion-proof motor powers the hammer mill. The rebuilt hammer mill was delivered in June, and performance processing of wood and straw material was evaluated during a brief test in July 2001.

Following delivery, inspection, and initial testing of the hammer mill, an order was placed with the hammer mill manufacturer for a blower assembly and additional screens. The blower assembly permits the product from the hammer mill to be efficiently recovered in a cyclone and collected in a hopper, with undersized material and dust collected in an existing dust control system. Final installation of the hammer mill, product recovery piping, and dust control piping occurred in January 2002 following delivery of the blower assembly and piping components. Equipment/material costs for the used hammer mill and supporting components were nominally $\$ 27,700$. Photographs of the hammer mill and product recovery cyclone are presented in Figure 7.

A new platform feeder and conveyor were purchased to support operation of the hammer mill. The platform feeder was procured to primarily support the processing of large quantities ( $>454 \mathrm{~kg}$, or $1000 \mathrm{lb}$ ) of low-density biomass (grass- or straw-type material and chipped wood) in the hammer mill at a controlled feed rate. However, the platform feeder may have application for other biomasshandling requirements. Operated in conjunction with the agricultural forage box, the platform feeder can be used indoors to air-dry biomass by continuously transferring biomass between the platform feeder and the forage box and back to the platform feeder until the desired surface moisture level is achieved. Platform feeder dimensions are nominally 3 by $4.3 \mathrm{~m}$ (10 by $14 \mathrm{ft})$, with drag bars and dual beaters delivering material to a cross-conveyor. The cross-conveyor belt material is a $51-\mathrm{cm}$ (20-in.)-wide raised-rib rubber with a fabric back. A 3.7-kW (5-hp/220-V) 3-phase explosion-proof motor-and-chain-drive assembly powers the platform feeder and permits variable-speed unloading. The platform feeder was ordered in June and delivered in August 2001 at a cost of nominally $\$ 10,200$. Assembly of the platform feeder was completed in September, and a short operational test was successfully performed. Final installation of the platform feeder was completed in conjunction with the hammer mill. Figure 8 is a photograph of the platform feeder.

The new conveyor purchased to support operation of the hammer mill is a portable unit nominally $0.6 \mathrm{~m}(2 \mathrm{ft})$ wide and $4.6 \mathrm{~m}(15 \mathrm{ft})$ long, powered by a $1.1-\mathrm{kW}(1.5-\mathrm{hp} / 230 / 460-\mathrm{V})$ 3 -phase explosion-proof motor and gear drive. Belt material is a $0.6-\mathrm{m}(2-\mathrm{ft})$-wide rubber z-top (Chevron) with fabric back. The elevation of the discharge end of the conveyor is adjustable to $1.8 \mathrm{~m}$ (6 ft) to simplify installation of the hammer mill and platform feeder and maximize the conveyor's versatility. A magnetic header roller was specified for the conveyor to minimize the potential for metal objects to be discharged into the hammer mill. The conveyor was procured to specifically deliver biomass to the hammer at a controlled rate. However, it may also have application for biomass transfer between the platform feeder and forage box for the purpose of biomass air drying. The conveyor was ordered in January and delivered in February 2002 at a cost of nominally $\$ 7150$. Final installation, wiring, and testing of the conveyor were completed in February 2002. The conveyor can be seen, located between the platform feeder and hammer mill, in the Figure 7 photographs. 

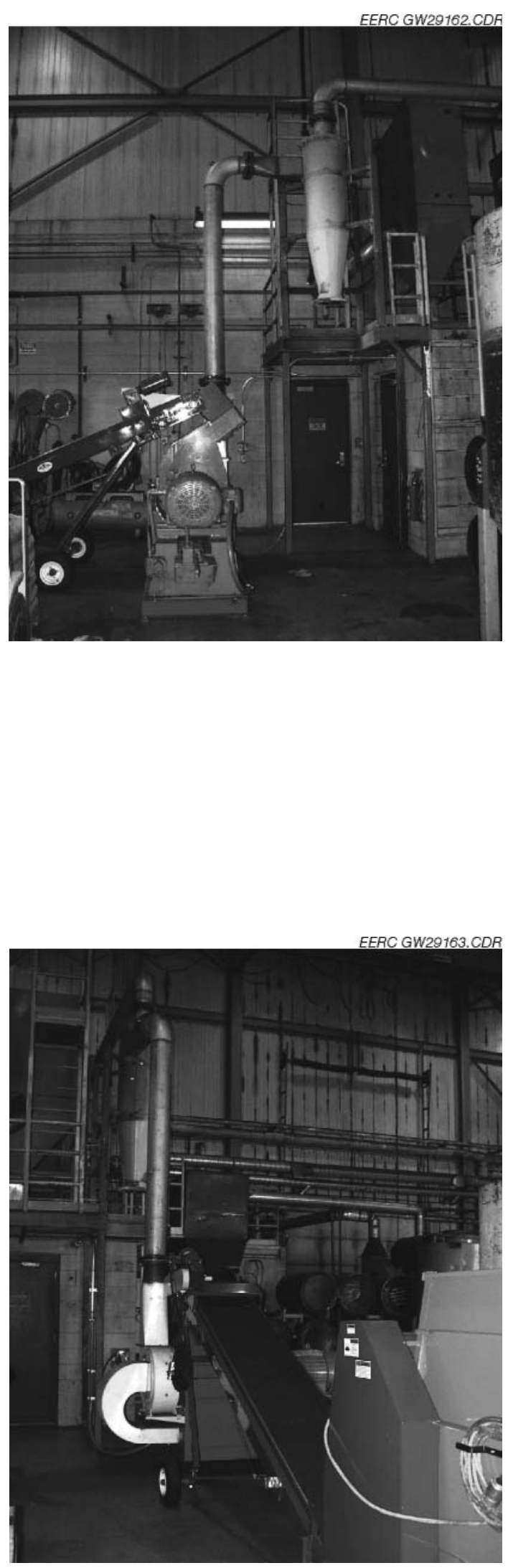

Figure 7. Photographs of hammer mill, blower assembly, and product recovery cyclone. 


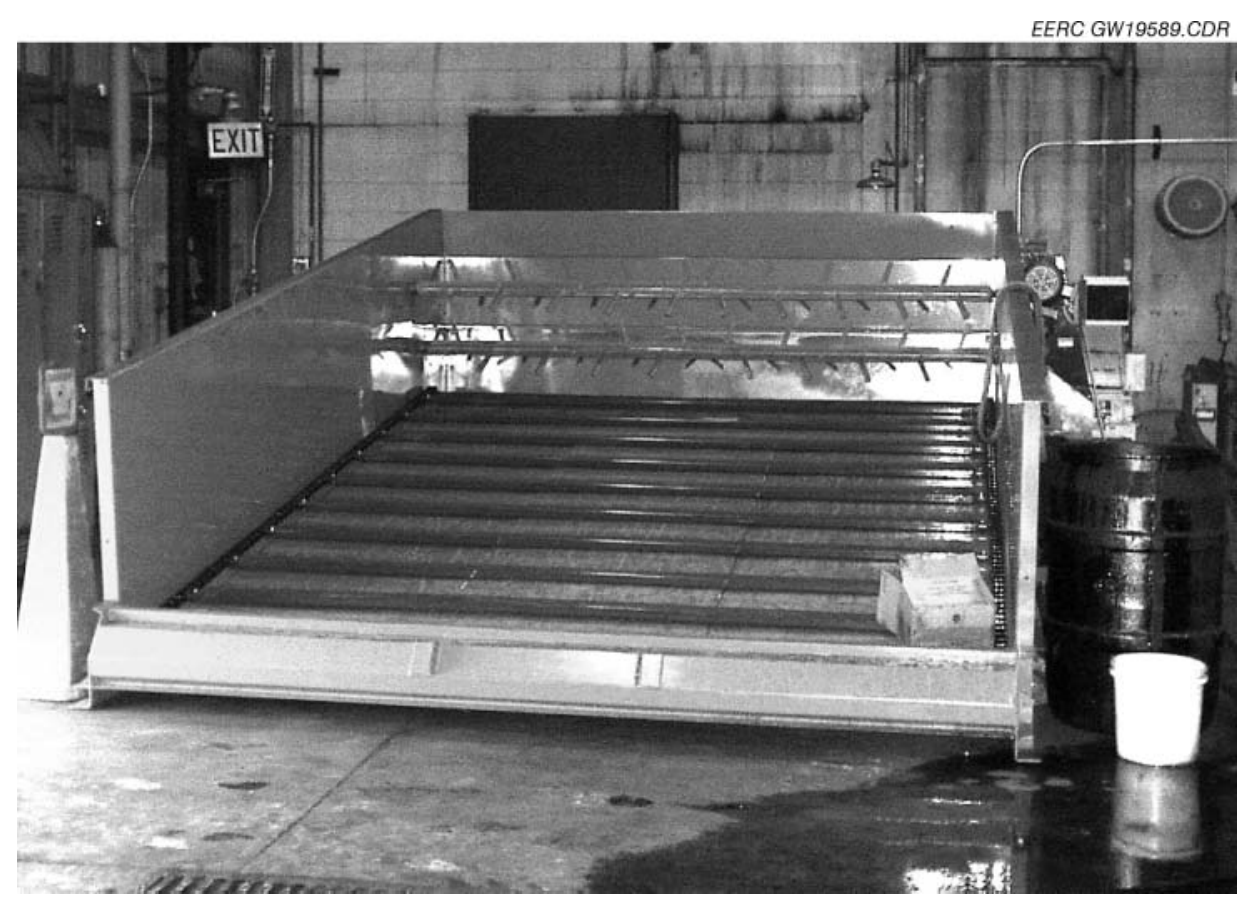

Figure 8. Photograph of platform feeder.

\section{Modifications to Pilot-Scale CTF}

Modifications to the CTF were necessary in order to facilitate its operation in a grate-fired configuration while maintaining its pc-firing capability. The CTF was selected for this modification because of an extensive existing ash deposition database resulting from the pc-firing of bituminous and subbituminous coal, lignite, petcoke, biomass fuels, and various fuel blends over the past $40+$ years. Figure 9 illustrates the CTF and auxiliary systems in a pc-fired configuration. As a result of the modifications made to facilitate grate firing, the only changes made involved fabricating a new bottom section for the combustor, combustion air piping, and the addition of a separate fuel feed system for grate firing.

Design work related to the modification of the pilot-scale combustor to permit its operation in a grate-fired configuration began in January 2001 and was essentially completed in June 2001. However, some limited design work continued on an intermittent basis in support of fabrication activities as well as modifications determined to be necessary as a function of system shakedown. Specific design work related to grate geometry, properly sizing the grate area to match the firing rate of the combustion system, combustion air distribution, and fuel feed options relative to grate geometry and size. Figure 10 is an illustration of the grate-fired section added to the CTF. The fixed grate, ram, and fuel feed hoppers are indicated in the Figure 10 illustration along with refractory layout and air distribution through the grate.

The final design resulted in a rectangular grate with a surface area of $0.12 \mathrm{~m}^{2}$, or $1.25 \mathrm{ft}^{2}(25$ $\times 46 \mathrm{~cm}$, or 10 in. $\times 18$ in.) in order to match the grate size to the combustion system firing rate (nominally $0.58 \mathrm{~kJ} / \mathrm{hr}$, or $0.55 \mathrm{MMBtu} / \mathrm{hr}$ ). The resulting grate area on a firing rate basis was $0.21 \mathrm{~m}^{2} / \mathrm{GJ}\left(2.27 \mathrm{ft}^{2} / \mathrm{MMBtu}\right)$. The grate is simply a $0.64-\mathrm{cm}(0.25$-in.) 316 stainless steel plate. 


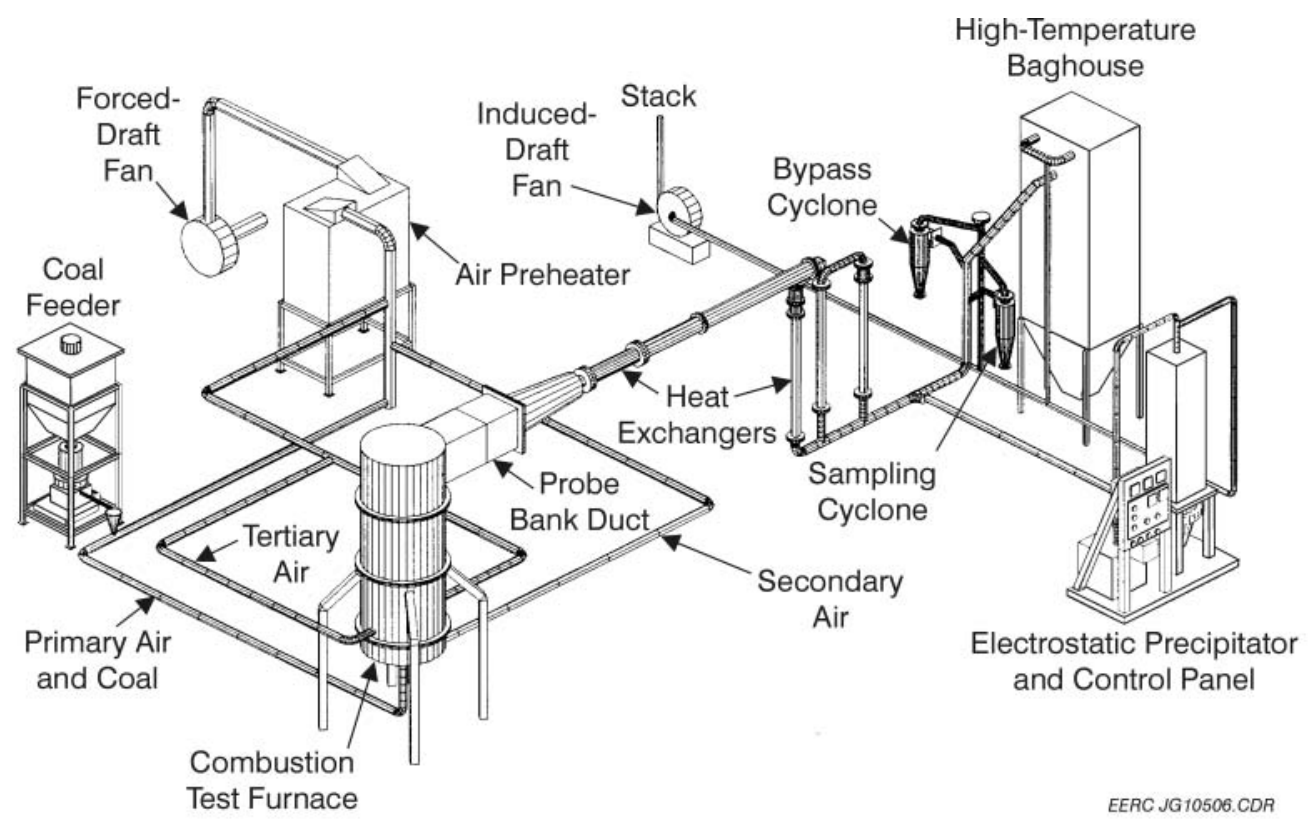

Figure 9. CTF and auxiliary systems for pc firing.

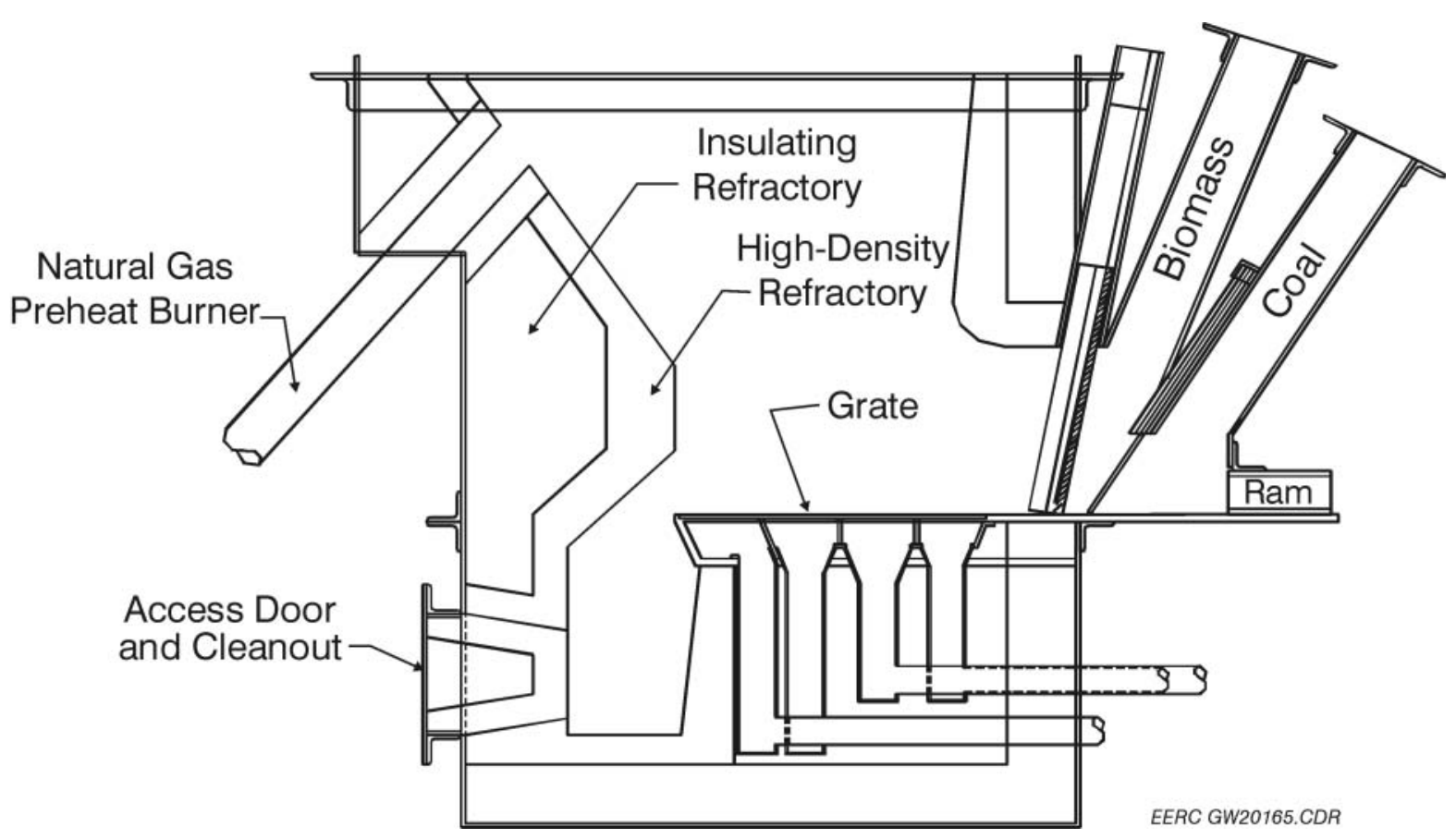

Figure 10. Illustration of components for grate-fired system. 
Grate open area was $3.43 \%$ based on 322 holes $(0.396 \mathrm{~cm}$, or $0.156 \mathrm{in}$.) drilled through the plate in a 14-row triangular pattern. Hole positioning was $1.588 \mathrm{~cm}(0.625 \mathrm{in}$.) on center between rows and $1.98 \mathrm{~cm}$ (0.78 in.) on center within each row. Row spacing was $1.707 \mathrm{~cm}$ (0.672 in.) on center.

The fixed-grate arrangement required the use of a ram to periodically move fuel and ash across the grate. Ram actuation frequency and stroke length vary depending on the fuel properties, firing rate, and whether a single fuel is fired or fuel cofiring is required. The fuel feed system makes use of a gravity feed dual-hopper-gate arrangement that permits the distribution of fuel on the fixed grate to a desired level for a given fuel particle size and heating value. Changes in fuel feed rate are made using a combination of adjustments to the elevation of the fuel gates and the operating frequency and stroke length of the ram over the fixed grate.

An ash collection area and access door for ash removal are indicated in Figure 10. Primary combustion airflow to the grate is controlled and divided into four zones over the length of the grate representing $18 \%, 30 \%, 28 \%$, and $24 \%$ of the grate area, respectively. Overfire air is injected through multiple opposing ports about $71 \mathrm{~cm}(28 \mathrm{in}$.) above the grate but not shown in Figure 10. Primary and overfire air represent $80 \%-90 \%$ and $10 \%-20 \%$ of the total combustion air, respectively. The overfire air ports are located at an elevation comparable to the natural gas preheat burner opening. The refractory-lined combustor is preheated firing natural gas prior to initiating solid fuel firing.

Preparation of conceptual and fabrication drawings and material procurement began in April and June 2001, respectively. Planned design activities were completed in November 2001. Fabrication of the components for the grate-fired system began in June 2001 and continued into November 2001. Shakedown tests completed in December 2001 resulted in excessive ash clinkering on the grate. EERC personnel felt that the ash clinkers initiated along the refractory walls adjacent to the grate and propagated across the grate surface. As a result, some additional design work and fabrication drawings were necessary to make modifications to the grate area in order to minimize ash clinkering on the grate. Modifications included fabricating a new grate, adding water-cooled surfaces to the refractory walls adjacent to the grate, and adding two additional sight ports to improve the ability to observe and access the grate on-line.

The new grate design increased the number of effective air nozzles but reduced the nozzle diameter in order to maintain the percent open grate area $(3.43 \%)$ desired. Hole diameters decreased from $0.396 \mathrm{~cm}(0.156 \mathrm{in}$.) to $0.239 \mathrm{~cm}(0.094 \mathrm{in}$.), and the number of holes increased from 322 to 837. Hole spacing within each row is now $1.572 \mathrm{~cm}$ (0.619 in.) on center, and row spacing is $0.785 \mathrm{~cm}$ (0.309 in.) on center.

In addition, water-cooled tubing was added to the air plenum side of the grate to improve grate thermal protection. The design modifications were documented in revised fabrication drawings. Fabrication of the new grate and installation of water-cooled surfaces and sight ports in the refractory walls were completed in mid-January, followed by a shakedown test to verify that the modifications made had successfully mitigated the ash clinkering previously observed.

Figure 11 presents photographs of the finished grate-fired system components installed on the CTF. The dark rust-colored section is the new CTF bottom permitting grate firing. Specific items visible in the photographs include 1) the fuel feed hoppers with sight windows to monitor fuel level, 


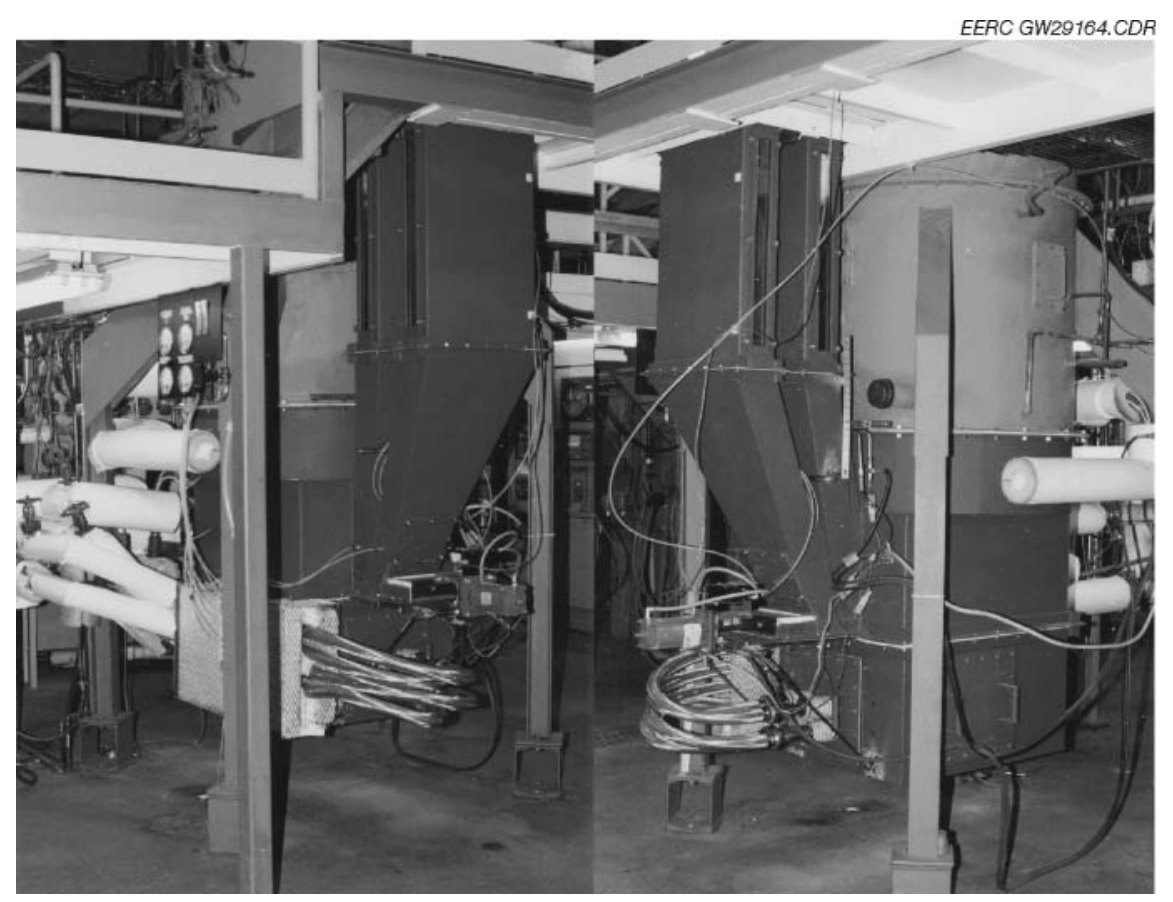

Figure 11. Photograph of grate-fired section added to CTF.

2) the ram and actuator at the base of the fuel hoppers, 3) stainless steel flex hoses delivering preheated primary air to the grate plenum, 4) insulated headers delivering preheated overfire air above the grate, and 5) some of the doors permitting access to the ash collection area below the grate. Further modifications to this grate-fired system are likely in the future to improve performance and increase flexibility. However, any further modifications would be addressed within future projects. Detailed fabrication drawings of all components for the grate-fired system are maintained in a design file at the EERC.

\section{Flue Gas Instrumentation and Data Acquisition System Upgrades}

In addition to modifications directly to the pilot-scale CTF fuel feed system and combustor, upgrades were also made to the flue gas instrumentation and data acquisition system. The flue gas conditioner and most of the flue gas analyzers supporting the CTF were more than 20 years old. As a result, reliability had deteriorated, maintenance costs were increasing, and spare parts were difficult to obtain if not discontinued. Hence, the age and condition of the equipment had the potential to affect flue gas data availability and quality. Therefore, the EERC elected to replace the flue gas conditioner and five flue gas analyzers as well as upgrade the data acquisition system.

The new flue gas sample conditioner and flue gas analyzers for $\mathrm{O}_{2}, \mathrm{CO}, \mathrm{CO}_{2}, \mathrm{SO}_{2}$, and $\mathrm{NO}_{\mathrm{x}}$ to support the operation of the modified pilot-scale combustion system were ordered in April 2001 and began to arrive in May, with the last instrument delivered in July 2001. The flue gas sample conditioner selected was supplied by Baldwin Environmental, Inc. (Cooler Model 20410S and conditioner Model 9BC3). This unit utilizes an electronic moisture condenser and a dual-stream conditioner, permitting simultaneous support of two sets of gas analyzers. 
A single analyzer was selected for the measurement of $\mathrm{O}_{2}, \mathrm{CO}_{2}$, and $\mathrm{CO}$. Rosemount Analytical (Model NGA2000-MLT3 A multimethod/multichannel analyzer with internal power supply) supplied the analyzer. Oxygen measurement is accomplished using a paramagnetic method with a minimum range of $0 \%$ to $5 \%$ and a maximum range of $0 \%$ to $100 \%$ on a dry volume basis. Carbon dioxide measurement is accomplished using a nondispersive infrared absorption spectrophotometer method with a minimum range of $0 \%$ to $5 \%$ and a maximum range of $0 \%$ to $100 \%$ on a dry volume basis. Carbon monoxide measurement is accomplished using a nondispersive infrared absorption spectrophotometer method with a minimum range of 0 to $100 \mathrm{ppm}$ and a maximum range of 0 to 5000 ppm on a dry volume basis.

AMETEK Process \& Analytical Instruments supplied the analyzer (Model No. 921 nondispersive ultraviolet absorption spectrophotometer) selected for the measurement of $\mathrm{SO}_{2}$. Sulfur dioxide measurement is accomplished using a nondispersive ultraviolet absorption spectrophotometer method with a minimum range of 0 to $500 \mathrm{ppm}$ and a maximum range of 0 to 5000 ppm on a dry volume basis.

Rosemount Analytical supplied the analyzer (Model NGA2000-CLD chemiluminescence $\mathrm{NO} / \mathrm{NO}_{\mathrm{x}}$ analyzer) selected for the measurement of $\mathrm{NO}_{\mathrm{x}}$. Nitrogen species measurements are accomplished using a chemiluminescence method with a minimum range of 0 to $50 \mathrm{ppm}$ and a maximum range of 0 to $1000 \mathrm{ppm}$ on a dry volume basis.

In general, the particular pieces of equipment purchased were selected because similar units previously acquired have proven to be very reliable and competitively priced. All of the analyzers are compact, permitting them to be mounted in a 19-in. rack. A single cabinet assembly was purchased to house the flue gas conditioner and analyzers, thus making the combination of components semiportable. Assembly of the new flue gas sample conditioner and analyzers was completed in July 2001 at a total equipment/material cost of $\$ 72,000$.

Upgrades to the data acquisition system included software as well as hardware. In addition to process thermocouple measurements, pressure measurements, and fuel feed data, output signals from the gas analyzers were incorporated into the upgraded data acquisition system. However, although these software upgrades will support process control automation, at this time process control for the CTF is still generally a manual operation.

Process control software upgrades were procured from a vendor supplying Iconics, Inc., products. Specific software items purchased included the following: 1) Gen32-1500, a human-machine interface incorporating graphics, trending, and alarming software; 2) ControlworX32-3, a process control development software; 3) DataWorX32G, an OPC (object linking and embedding for process control) data-bridging software; and 4) Gen32-Browser, a secondary computer interface package for Gen32-1500. This suite of software is used for supervisory control of pilot-scale equipment. The software provides an interface to field data and hardware used to provide trending and alarming, data collection, and control operations. This automation software is based completely on the new OPC standard providing true 32-bit-based processing for graphics, trending, alarming, and OPC servers. A significant part of the rationale for the software upgrade was that the existing 16-bit technology is slowly being phased out and will not be supported in the future. However, since this was a software upgrade, it was not necessary to 
totally reconstruct the existing data acquisition and process control programs supporting the pilotscale CTF.

Specific hardware items purchased include the following: 1) five 8-channel, 16-bit analog input modules; 2) thirteen 8-channel, 16-bit thermocouple input modules; 3) an 8-channel, 4-20-ma output module; 4) 19 universal screw terminal bases; 5) a RS-232/RS-485 network module with documentation and software; 6) an RS-485 network module; 7) a 9-pin D-sub RS-232 cable; and 8 ) a new computer, monitor, and printer. These hardware upgrades were necessary to support the software upgrades previously described.

The software and hardware packages identified were ordered in February and April 2002, respectively, and were delivered in April 2002. Software costs were nominally $\$ 4500$, and hardware costs were nominally $\$ 11,100$. These upgrades were not completed earlier in the project because they were considered a lower priority and were delayed pending completion of other project activities.

\section{Task 3 - Verification Testing of the Simulator}

The primary objective of Task 3 was to shake down and verify the performance of the modified pilot-scale grate-fired combustion system prior to the performance of pilot-scale combustion tests in Task 5. Specific activities included verification of the fuel feed system modifications to facilitate operation of the CTF in a grate-fired configuration and operation of the modified CTF combustor in a grate-fired configuration. Other activities included performance verification of 1) biomass fuel storage, handling, and preparation capabilities; 2) the new flue gas sample conditioner to support flue gas analyzer operation; and 3) new flue gas analyzers to measure $\mathrm{O}_{2}, \mathrm{CO}, \mathrm{CO}_{2}, \mathrm{SO}_{2}$, and $\mathrm{NO}_{\mathrm{x}}$.

\section{Modifications to Pilot-Scale CTF}

Modifications to the CTF were necessary in order to facilitate its operation in a grate-fired configuration while maintaining its pc-firing capability. The CTF was selected for this modification because of an extensive existing ash deposition database resulting from the pc-firing of various fuels and fuel blends over the past $40+$ years. The modifications required to facilitate grate firing involved fabricating a new bottom section for the combustor, installation of new combustion air piping to support primary and overfire air requirements, and the addition of a separate fuel feed system to support grate firing of a single fuel as well as fuel blends. These modifications are illustrated in Figure 10 and shown in Figure 11, respectively.

Fabrication and assembly activities were completed in November, and shakedown tests began in December 2001. Initial shakedown tests were conducted using a subbituminous coal, the same coal used during Task 5 pilot-scale tests, with subsequent shakedown tests completed cofiring the subbituminous coal and wood chips. Results from the shakedown tests demonstrated that the fuel feed system worked as designed when feeding a single fuel such as the subbituminous coal. Coal was initially sized to $-2.5 \mathrm{~cm}(-1.0$ in.) and $+0.64 \mathrm{~cm}(+0.25$ in.). However, shakedown tests indicated that a smaller top size $(1.9 \mathrm{~cm}$, or $0.75 \mathrm{in}$.) improved pilot-scale grate-fired system performance. The improvement in performance with reduced coal top size is characteristic of the scale at which this project was conducted and not indicative of coal size requirements for 
commercial grate-fired systems. Full-scale grate-fired systems effectively use coal top-sized to $5 \mathrm{~cm}$ (2 in.) and larger.

When initially attempting to cofire wood chips, the wood chip feed was inconsistent because of bridging in the fuel hopper. This problem was mitigated to a significant degree as a result of processing the wood chips through the hammer a second time to eliminate oversized material (wood chips having a length-to-diameter ratio of $>2$ ). For both the first and second passes through the hammer mill, the wood chips were processed using a $1.3-\mathrm{cm}(-0.5-\mathrm{in}$.) screen. The same result could have been achieved using a classifier to recover the oversized material and then processing the oversized material through the hammer mill. Another mitigating procedural item was not filling the biomass feed hopper to capacity, reducing packing in the hopper. However, more frequent refills were required. For biomass cofiring at the pilot scale, an alternative to the gravity-based arrangement used in support of this project may be warranted. One option worth considering is a screw feed system that would deliver biomass fuel to the front of the grate. However, the discharge screw would require water cooling to survive the temperature regime.

As with the coal, problems with oversized wood chips was more a characteristic of the scale at which this project was conducted and not indicative of fuel size requirements for commercial grate-fired systems. A study completed by the EERC to evaluate wood chip firing in an industrial grate-fired system determined that a nominal 5-cm (2-in.) product from a hammer mill would be acceptable while limiting undersized material $(-0.64 \mathrm{~cm} /-0.25$ in.) to avoid excessive fuel entrainment from the grate (59). Depending on the condition and configuration of the existing fuel feed system, wood chips could be blended with the coal feed in existing equipment. However, in some cases, fuel feed equipment upgrades are required.

Subsequent pilot-scale tests cofiring sunflower hulls demonstrated that the sunflower hulls fed more consistently through the gravity-based feed system than the wood chips because of their more uniform size distribution and generally less angular shape. A study completed by the EERC to evaluate sunflower hull firing in an industrial grate-fired system determined that sizing of the sunflower hulls was not necessary and the sunflower hulls could be blended and fed with the coal using existing equipment (58). Although the sunflower hulls were observed to entrain above the grate upon being fed through a spreader stoker, they were effectively burned out in the furnace as a result of air mixing above the grate. Generally, some modification of overfire airflow rate and distribution would be appropriate in order to optimize cofiring biomass material such as sunflower hulls. Depending on the condition and configuration of the existing fuel-handling/feed system, some upgrades may be necessary to control fugitive dust when blending sunflower hull-type biomass with coal.

A modification to the ram also improved the performance of the pilot-scale fuel feed system. Specifically, the height of the ram was reduced from $7.6 \mathrm{~cm}$ (3.0 in.) to $3.8 \mathrm{~cm}(1.5 \mathrm{in}$.), reducing its cross-sectional area. This change resulted in an increased ram stroke frequency for a given fuelfiring rate. Further modifications to the fuel feed system supporting the pilot-scale grate-fired combustor are likely in the future to improve performance and increase flexibility. However, any modifications are likely to be fuel-specific and are beyond the scope of this project and would be addressed within future projects. 


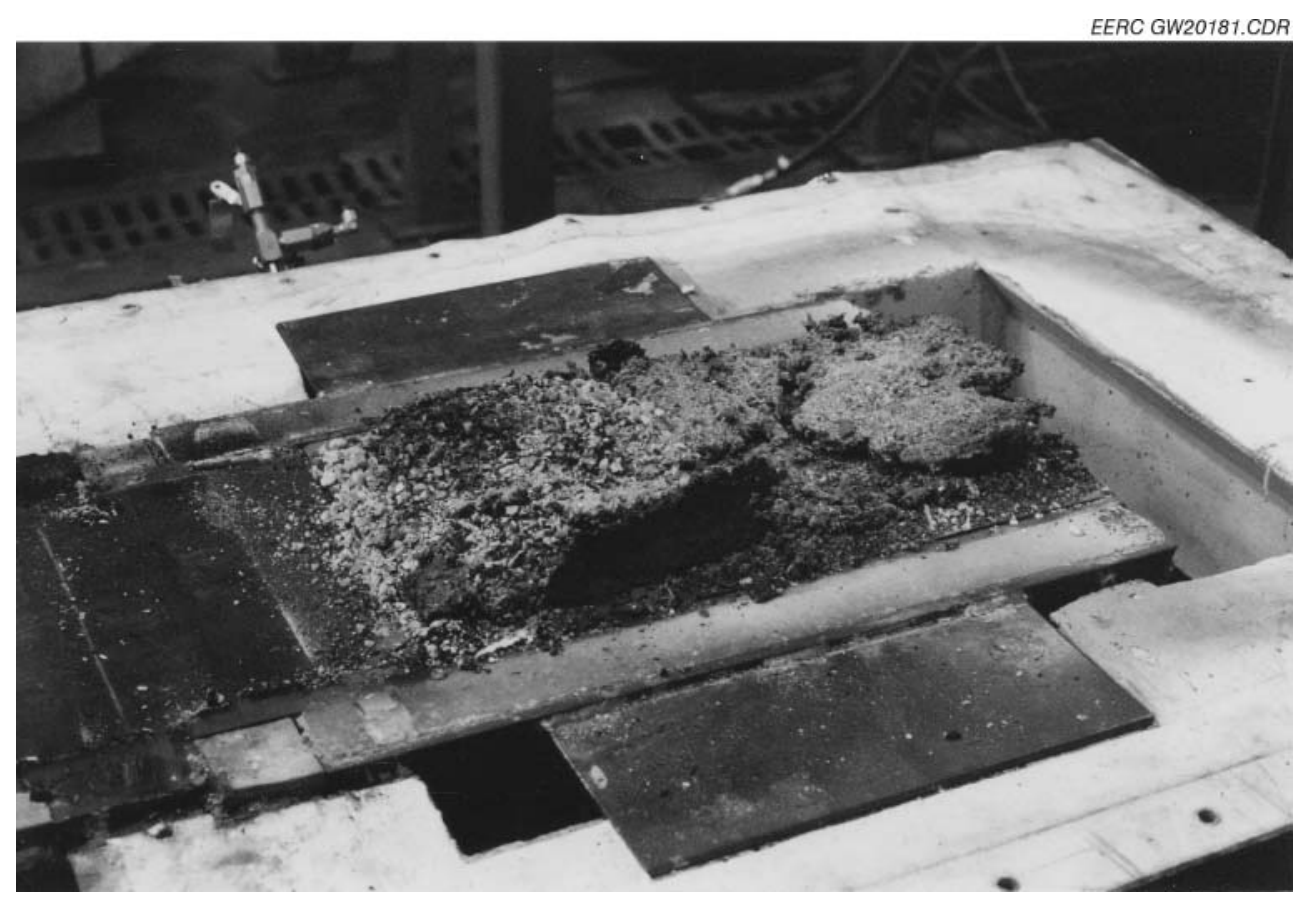

Figure 12. Extensive ash clinkering on grate.

Shakedown tests also resulted in excessive ash clinkering on the grate. EERC personnel felt that the ash clinkers initiated along the refractory walls adjacent to the grate and propagated across the grate surface. Figure 12 is a photograph of extensive clinkering on the grate that forced a shutdown. Modifications to mitigate the ash clinkering included fabricating a new grate, adding water-cooled surfaces to the refractory walls adjacent to the grate, and adding two additional sight ports to improve the ability to observe and access the grate on-line. Figure 13 is a photograph of bottom ash recovered after a subsequent grate-fired test. Although clinkering on the grate was not eliminated, it was reduced to a point that permitted the successful completion of grate-fired tests. Bottom ash carbon content was $6-12 \mathrm{wt} \%$ as a result of successfully completed grate-fired tests. Process data and sample analysis results from shakedown tests are discussed in greater detail later in this report along with data generated in Task 5.

Further modifications to the pilot-scale grate-fired combustor are likely in the future to improve performance and increase flexibility. In addition, EERC personnel believe operational changes would also further reduce grate clinkering and result in other improvements in overall combustor performance. Some of these include reducing fuel particle size, reducing the thickness of the fuel bed on the grate, changes in primary and overfire air distribution, and changes to the biomass component of the fuel feed system. As previously discussed, a screw feeder may be a better option for some biomass types. Other options may include air-assisted feeder configurations. However, any further modifications or evaluation of operational changes are beyond the scope of this project and would be addressed in future projects. 


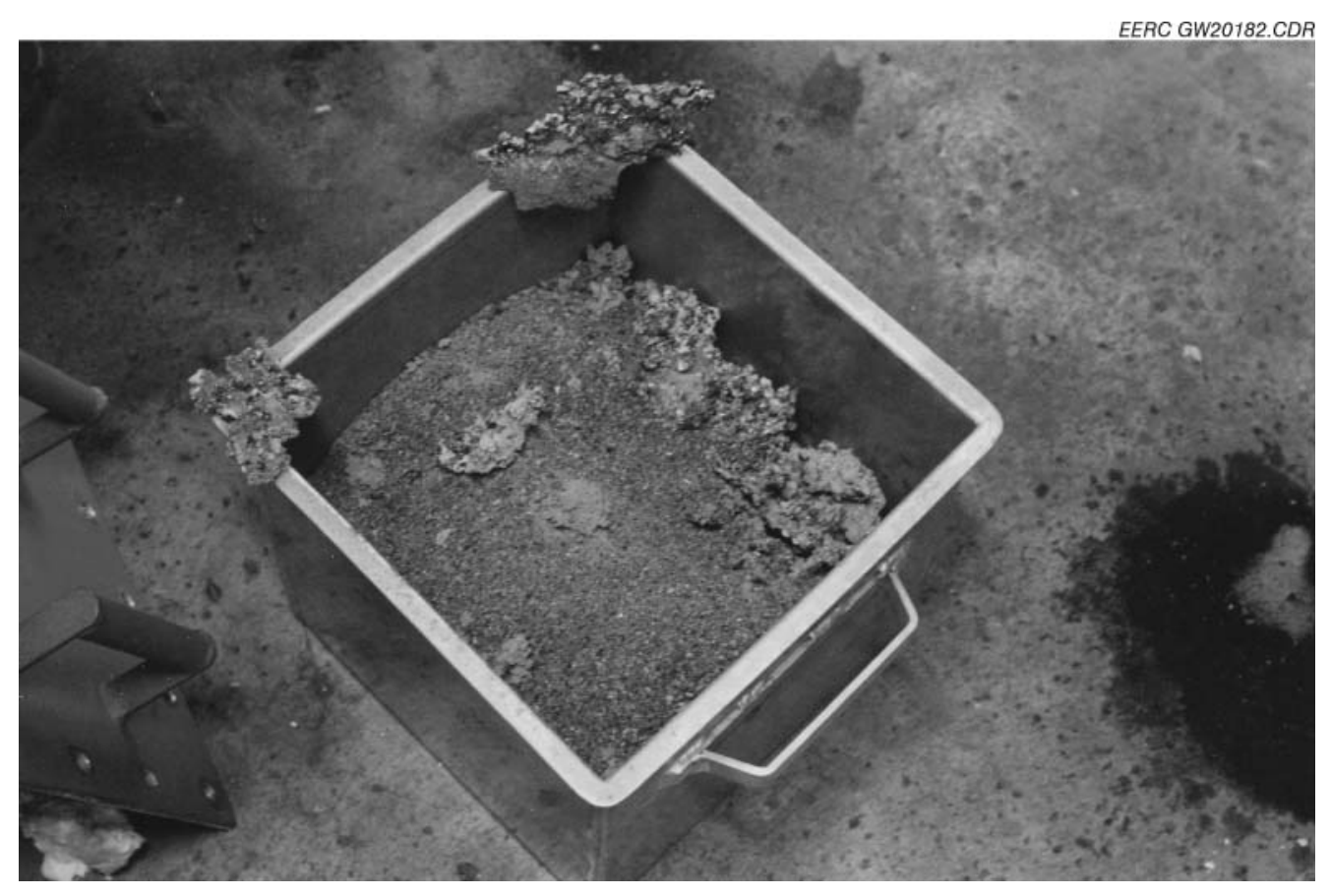

Figure 13. Bottom ash recovered after subsequent grate-fired test.

\section{Fuel Storage and Preparation}

In order to address biomass storage and handling requirements, the EERC purchased a used walking-floor semitrailer and a new agricultural forage box. The used walking-floor semitrailer is a 1979 Budd walking floor trailer (12-m, or 40-ft, tractor trailer) with a nominal capacity on a volumetric basis of $72 \mathrm{~m}^{3}\left(2560 \mathrm{ft}^{3}\right)$. Assuming a material bulk density of $240 \mathrm{~kg} / \mathrm{m}^{3}\left(15 \mathrm{lb} / \mathrm{ft}^{3}\right)$, the capacity of the trailer would be approximately $17,000 \mathrm{~kg}(38,000 \mathrm{lb}$, or 19 tons). The new forage box is a 5.5-m/12,700-kg (18-ft/14-ton) front-rear combination unload Badger forage box with a nominal capacity on a volumetric basis of $23 \mathrm{~m}^{3}\left(800 \mathrm{ft}^{3}\right)$. Assuming a material bulk density of $240 \mathrm{~kg} / \mathrm{m}^{3}\left(15 \mathrm{lb} / \mathrm{ft}^{3}\right)$, the capacity of the trailer would be approximately $5450 \mathrm{~kg}(12,000 \mathrm{lb}$, or 6 tons). The performance of the walking-floor semitrailer and agricultural forage box were verified during short operability tests using a portable hydraulic system powered with a $7.5-\mathrm{kW}$ (10-hp) gasoline engine. Specifically, the floor of the walking-floor semitrailer and the cross-conveyor and apron of the forage box were operated for nominally 30-minute periods. Both trailers were demonstrated to be road worthy as a result of their cross-country delivery.

Fuel preparation to support pilot-scale activities had to address two requirements: 1) the potential need to dry a given quantity of biomass and 2) the need to properly size the biomass for a given combustion or gasification system. Since biomass drying was considered a low priority for this project and drying options would be highly material-dependent, no attempts were made to demonstrate the drying potential of the equipment purchased to support biomass storage and preparation capabilities.

The EERC's primary objectives for fuel-sizing equipment were adequate capacity (227 to $454 \mathrm{~kg} / \mathrm{hr}$, or 500 to $1000 \mathrm{lb} / \mathrm{hr}$ ) and size reduction capabilities to specifically match fuel size 
requirements for existing pilot-scale combustion and gasification systems. To address biomass fuelsizing requirements, the EERC purchased a used hammer mill and a new platform feeder and conveyor to support operation of the hammer mill. The hammer mill is a rebuilt electrically driven Jacobson hammer mill, Model 556DF11, with a quick-change half-screen arrangement set up to discharge product through an outlet blower, with product recovery in a cyclone. Depending on the feed material type and size and desired product size, processing capacity should be 227 to $454 \mathrm{~kg} / \mathrm{hr}$ $(500$ to $1000 \mathrm{lb} / \mathrm{hr})$. Processing kiln-dried hardwood scraps into wood chips resulted in a product rate of $227 \mathrm{~kg} / \mathrm{hr}(500 \mathrm{lb} / \mathrm{hr})$. Straw/grass-type biomass was also processed in the hammer mill, but the small quantity of material processed did not lend itself to determination of a product mass rate. Softwood and straw/grass-type biomass should result in a product rate of at least $454 \mathrm{~kg} / \mathrm{hr}$ $(1000 \mathrm{lb} / \mathrm{hr})$.

A new platform feeder and conveyor were purchased to support operation of the hammer mill. The platform feeder was procured to primarily support the processing of large quantities $(>454 \mathrm{~kg}$, or $>1000 \mathrm{lb}$ ) of low-density biomass (grass or straw-type material and chipped wood) in the hammer mill at a controlled feed rate. The new conveyor was purchased to deliver biomass to the hammer mill from the platform feeder or other source. Both the platform feeder and conveyor are electrically driven, and belt speed is adjustable. The platform feeder and conveyor have been operated for short periods of time to verify their general performance.

Depending on the type of biomass available for industrial use, similar types of equipment would have application for biomass cofiring projects. However, the equipment would have to be properly sized and configured to match the type and quantity of biomass to be cofired. For example, sunflower hulls have very different handling and processing requirements than various wood wastes. Individually, various wood wastes (saw dust, construction and demolition material, pallets, logging waste, etc.) have very different handling and processing requirements. Straw- and grass-type biomass materials have different handling and processing requirements than either sunflower hulls or wood wastes. Storage, handling, and processing equipment selection and configuration required to support biomass cofiring must be addressed on a site-specific basis. However, this type of material handling is not new, and equipment options exist including used equipment. In addition, many industrial biomass-cofiring sites will be similar, and lessons learned from site to site must be exploited.

\section{Flue Gas Instrumentation and Data Acquisition System Upgrades}

The new flue gas sample conditioner and flue gas analyzers for $\mathrm{O}_{2}, \mathrm{CO}, \mathrm{CO}_{2}, \mathrm{SO}_{2}$, and $\mathrm{NO}_{\mathrm{x}}$ were initially evaluated using nitrogen as a zero gas and certified calibration standards to verify performance within vendor-specified operating limits for accuracy and linearity. Output signals to the data acquisition system were also verified. Further verification of these instruments was completed as a function of shakedown tests with the modified pilot-scale combustion system. To date, these instruments have met manufacturer performance specifications as well as EERC expectations.

Upgrades to the data acquisition system software and hardware are ongoing. These upgrades were not completed earlier in the project because they were considered a lower priority and were delayed pending completion of other project activities. Therefore, verification efforts associated with data acquisition system upgrades will be completed subsequent to the completion of this report. 


\section{Task 4 - Laboratory-Scale Testing and Fuel Characterization}

\section{Characterization of Parent Fuels}

The proximate, ultimate, and ash chemistry of the Cordero Rojo coal, biomass samples, and coal-biomass blends are given in Table 4. The coal-biomass blends were calculated based on the analysis of the coal and biomass samples. Because of the high level of volatile matter and other inorganic material in the biomass samples, ashing was performed at a lower temperature than for coal procedures $575^{\circ} \mathrm{C}\left(1067^{\circ} \mathrm{F}\right)$, following American Society for Testing and Materials Procedure E 1755-95. The biomass materials are characterized by a significantly higher volatile matter and a slightly lower fixed-carbon content than the Cordero Rojo coal. The biomass samples also show a higher oxygen content and lower sulfur content. The sunflower hulls contain significantly higher ash content relative to the coal, while the ash content of the wood chips is extremely low. Both biomass samples have significantly higher chlorine content than the coal, almost an order of magnitude higher. Both biomass fuels were delivered in a fairly dry state and have heating values that are very close to the coal.

The dry sieve analysis of the incoming biomass and the ash fusion temperatures of the ash are given in Tables 5 and 6. In general, the biomass samples were $1 / 4$ in. $(6.35 \mathrm{~mm})$ or smaller. For both the sunflower hulls and the wood chips, approximately $70 \%$ or more of the biomass samples were received in the mesh size range of 10 mesh to $1 / 4$ in. (2 to $6.35 \mathrm{~mm}$ ). The ash fusion temperatures of the wood chips were slightly higher than those of the coal. The sunflower hulls showed unusual ash fusion temperatures that exceeded the temperature range of the analysis. The ash fusion test was repeated, and the results were again the same. The ash cones that failed remained in the same shape as they started, merely shrinking in size. The cones were weighed before and after the test. The cones lost almost $80 \%$ of their mass during the test but did not melt. The cones were analyzed for chemistry before and after the test using SEM energy-dispersive x-ray (EDX) analysis. The bulk chemistry of the cones before and after is shown in Table 7. The ash cone lost almost all of the potassium, which was the major constituent prior to the analysis. This material was volatilized during the heating for the test along with the bulk of the phosphorus and magnesium. The major element left behind in the cone was the calcium which then became the primary inorganic of the cone. The ash fusion test is obviously not an appropriate analysis for this material.

CCSEM major mineral species for the coal and biomass samples are given in Table 8 . The wood chips show the presence of carbonates and quartz or amorphous silica, which are common in wood, and various small quantities of aluminosilicates. Iron oxide is also identified as a major phase, which is probably a remnant of the manufacturing process from which the wood was obtained. The wood material came from a furniture manufacturer, and the iron could be from saw blades or other cutting tools used in the process.

The Cordero Rojo coal showed high levels of kaolinite and quartz. Both the wood chips and sunflower hulls contain a significant amount of unclassified mineral content due primarily to the abundant presence of organically associated potassium and amorphous silica. SEM beam effects will produce x-rays from potassium and other organically bound elements in the organic matrix of the sunflower hulls and wood biomass when a small $1-5-\mu \mathrm{m}$ particle is being analyzed. The end result is a chemistry that does not fit any of the CCSEM mineral categories. Total ash content ranged from $4 \%-8 \%$ for the coal and sunflower hulls, while the wood chips showed less than $1 \%$ ash. 
Table 4. Proximate and Ultimate Analysis of Fuels

\begin{tabular}{|c|c|c|c|c|c|c|c|}
\hline & $\begin{array}{c}\text { Cordero } \\
\text { Rojo } \\
\text { Coal } \\
\end{array}$ & $\begin{array}{c}\text { Sunflower } \\
\text { Hull } \\
\text { Biomass } \\
\end{array}$ & $\begin{array}{c}\text { Wood } \\
\text { Chip } \\
\text { Biomass }\end{array}$ & $\begin{array}{c}80 \% \\
\text { Coal- } \\
20 \% \\
\text { Sflr Hulls } \\
\end{array}$ & $\begin{array}{c}60 \% \\
\text { Coal- } \\
40 \% \\
\text { Sflr Hulls } \\
\end{array}$ & $\begin{array}{c}80 \% \\
\text { Coal- } \\
20 \% \\
\text { Wd Chips } \\
\end{array}$ & $\begin{array}{c}60 \% \\
\text { Coal- } \\
40 \% \\
\text { Wd Chips } \\
\end{array}$ \\
\hline \multicolumn{8}{|c|}{ Proximate Analysis, as-received, wt $\%$} \\
\hline Moisture & 26.3 & 11.60 & 7.30 & 23.36 & 20.42 & 22.50 & 18.70 \\
\hline $\begin{array}{l}\text { Volatile } \\
\text { Matter }\end{array}$ & 35.00 & 69.45 & 76.82 & 41.89 & 48.78 & 43.36 & 51.73 \\
\hline Fixed Carbon & 33.76 & 11.61 & 15.25 & 29.33 & 24.90 & 30.06 & 26.36 \\
\hline Ash & 4.94 & 7.34 & 0.63 & 5.42 & 5.90 & 4.08 & 3.22 \\
\hline \multicolumn{8}{|c|}{ Ultimate Analysis, as-received, $\mathrm{wt} \%$} \\
\hline Hydrogen & 6.19 & 6.71 & 6.12 & 6.29 & 6.40 & 6.18 & 6.16 \\
\hline Carbon & 49.66 & 44.41 & 46.85 & 48.61 & 47.56 & 49.10 & 48.54 \\
\hline Nitrogen & 1.08 & 1.01 & 0.17 & 1.07 & 1.05 & 0.90 & 0.72 \\
\hline Sulfur & 0.35 & 0.27 & 0.18 & 0.33 & 0.32 & 0.32 & 0.28 \\
\hline Oxygen & 37.78 & 40.25 & 46.05 & 38.27 & 38.77 & 39.43 & 41.09 \\
\hline Ash & 4.94 & 7.34 & 0.63 & 5.42 & 5.90 & 4.08 & 3.22 \\
\hline $\begin{array}{l}\text { Heat Content, } \\
\text { Btu/lb }\end{array}$ & 8862 & 7815 & 8274 & 8653 & 8443 & 8744 & 8627 \\
\hline \multicolumn{8}{|l|}{ Chlorine, ppm } \\
\hline Dry Basis & 77 & 665 & 700 & 195 & 312 & 202 & 326 \\
\hline As Received & 57 & 588 & 649 & 149 & 248 & 156 & 265 \\
\hline \multicolumn{8}{|c|}{$\begin{array}{l}\text { X-Ray Fluorescence (XRF) Analysis } \\
\text { Oxide, } w t \% \text { of ash }\end{array}$} \\
\hline $\mathrm{SiO}_{2}$ & 30.0 & 4.8 & 28.4 & 22.0 & 16.0 & 30.0 & 29.8 \\
\hline $\mathrm{Al}_{2} \mathrm{O}_{3}$ & 22.1 & 1.6 & 11.3 & 15.5 & 10.6 & 21.6 & 21.0 \\
\hline $\mathrm{Fe}_{2} \mathrm{O}_{3}$ & 7.4 & 0.7 & 10.3 & 5.3 & 3.7 & 7.4 & 7.7 \\
\hline $\mathrm{TiO}_{2}$ & 1.9 & 0.1 & 0.5 & 1.3 & 0.9 & 1.9 & 1.7 \\
\hline $\mathrm{P}_{2} \mathrm{O}_{5}$ & 1.2 & 8.0 & 1.4 & 3.4 & 5.0 & 1.2 & 1.2 \\
\hline $\mathrm{CaO}$ & 29.9 & 12.8 & 29.2 & 24.4 & 20.3 & 29.8 & 29.8 \\
\hline $\mathrm{MgO}$ & 5.5 & 9.9 & 6.1 & 6.9 & 7.9 & 5.6 & 5.5 \\
\hline $\mathrm{Na}_{2} \mathrm{O}$ & 1.7 & 0.0 & 5.0 & 1.1 & 0.8 & 1.9 & 2.1 \\
\hline $\mathrm{K}_{2} \mathrm{O}$ & 0.4 & 62.1 & 7.8 & 20.2 & 34.8 & 0.7 & 1.2 \\
\hline
\end{tabular}

CHF involves a series of extractions with water, $1 \mathrm{M}$ ammonium acetate, and $1 \mathrm{M} \mathrm{HCl}$ to quantify organically bound inorganics and minerals of $<1 \mu \mathrm{m}$. Significant organically bound inorganics are found only in low-rank fuels, comprising the bulk of the inorganics of $<1 \mu \mathrm{m}$. Together, CCSEM and CHF give a complete inorganic characterization. The percentages of ionexchangeable material (soluble in water and ammonium acetate) are given in Table 9. For the 
Table 5. Dry Sieve of Fuels

\begin{tabular}{lccc}
\hline $\begin{array}{l}\text { Sieve Analysis, \% retained (screen } \\
\text { mesh, mm) }\end{array}$ & $\begin{array}{c}\text { Cordero Rojo } \\
\text { Coal }\end{array}$ & $\begin{array}{c}\text { Sunflower Hull } \\
\text { Biomass }\end{array}$ & Wood Chip Biomass \\
\hline 3/4 in. (19.05) & 13.7 & 0 & 0.4 \\
7/16 in. (11.1125) & 12.4 & 0 & 8 \\
$1 / 4$ in. (6.35) & 11.1 & 3.2 & 22.9 \\
$6(3.4)$ & 7.9 & 60.7 & 43.4 \\
$10(2)$ & 2.7 & 24.6 & 5.2 \\
$20(0.85)$ & 7.8 & 8.3 & 5.2 \\
Pan (pan) & 44.5 & 3.2 & 14.9 \\
\hline
\end{tabular}

Table 6. Ash Fusion Temperature, ${ }^{\circ} \mathrm{C}\left({ }^{\circ} \mathrm{F}\right)\left(*\right.$ temperature above $\left.2800^{\circ} \mathrm{F}\right)$

\begin{tabular}{lccc}
\hline & $\begin{array}{c}\text { Cordero Rojo } \\
\text { Coal }\end{array}$ & $\begin{array}{c}\text { Sunflower Hull } \\
\text { Biomass* }\end{array}$ & Wood Chip Biomass \\
\hline Initial Temperature & $1196(2185)$ & $1538(2800)$ & $1256(2293)$ \\
Softening Temperature & $1204(2201)$ & $1538(2800)$ & $1268(2315)$ \\
Hemispherical Temperature & $1213(2215)$ & $1538(2800)$ & $1289(2352)$ \\
Fluid Temperature & $1217(2223)$ & $1538(2800)$ & $1306(2383)$ \\
\hline
\end{tabular}

Table 7. Ash Fusion Cone Analysis Before and After Analysis, wt\%

\begin{tabular}{lcc}
\hline & \multicolumn{2}{c}{ SEM EDX Analysis of the Ash Fusion Cones } \\
& Ash Cone Before & Ash Cone After \\
\hline $\mathrm{Na}$ & 0.12 & 0.37 \\
$\mathrm{Mg}$ & 5.52 & 0.26 \\
$\mathrm{Al}$ & 0 & 0.1 \\
$\mathrm{Si}$ & 0 & 1.18 \\
$\mathrm{P}$ & 9.69 & 18.85 \\
$\mathrm{~S}$ & 0.06 & 0 \\
$\mathrm{Cl}$ & 0.07 & 0.05 \\
$\mathrm{~K}$ & 58.98 & 1.26 \\
$\mathrm{Ca}$ & 1.11 & 52.21 \\
$\mathrm{Ti}$ & 0 & 0 \\
$\mathrm{Cr}$ & 0 & 0.24 \\
$\mathrm{Fe}$ & 0 & 0 \\
$\mathrm{Ba}$ & 0 & 0.23 \\
$\mathrm{O}$ & 24.45 & 25.27 \\
\hline
\end{tabular}

Cordero Rojo coal, significant solubility and assumed organic association are seen for $\mathrm{Ca}, \mathrm{Mg}$, and $\mathrm{Na}$, while much lower or almost no solubility is observed for $\mathrm{Si}, \mathrm{Al}, \mathrm{Fe}, \mathrm{Ti}$, and $\mathrm{P}$, which have primarily mineral associations. Potassium is shown to remain mostly in an unleachable state because of its association with illitic clay. The chemical fraction behavior of the biomass materials is quite 
Table 8. CCSEM Analysis

\begin{tabular}{lccc}
\hline Mineral Fraction & $\begin{array}{c}\text { Cordero Rojo } \\
\text { Coal, wt } \%\end{array}$ & $\begin{array}{c}\text { Sunflower Hull } \\
\text { Biomass, wt } \%\end{array}$ & $\begin{array}{c}\text { Wood Chip } \\
\text { Biomass, wt \% }\end{array}$ \\
\hline Quartz & 32.3 & 1.8 & 9.6 \\
Iron Oxide & 5.3 & 1 & 9.2 \\
Calcite & 0 & 4.2 & 3.4 \\
Kaolinite & 26 & 0.3 & 3.8 \\
Montmorillonite & 5.9 & 0 & 1 \\
K Al-Silicate & 0.8 & 1.5 & 9.2 \\
Fe Al-Silicate & 0.5 & 0.2 & 3.7 \\
Ca Al-Silicate & 2.9 & 0.1 & 4.9 \\
Mixed Al-Silica & 1.2 & 0.2 & 1.9 \\
Fe Silicate & 0.1 & 0.1 & 0.3 \\
Pyrrhotite & 4.1 & 0 & 0 \\
Oxidized Pyrrhotite & 0.1 & 0 & 0.3 \\
Ca Al-Phosphate & 4.6 & 0 & 0.2 \\
Gypsum/Al-Silicate & 1.4 & 0 & 1.9 \\
Si-Rich & 0.8 & 0.7 & 6.3 \\
Unknown & 9.7 & 86.4 & 33.9 \\
\hline
\end{tabular}

Table 9. CHF Analysis of Fuels, \% removed by water and ammonium acetate

\begin{tabular}{lccc}
\hline Element & $\begin{array}{c}\text { Cordero Rojo Coal, } \\
\text { t } \%\end{array}$ & $\begin{array}{c}\text { Sunflower Hull Biomass, } \\
\text { wt } \%\end{array}$ & $\begin{array}{c}\text { Wood Chip Biomass, } \\
\text { wt } \%\end{array}$ \\
\hline $\mathrm{Si}$ & 0 & 32 & 76 \\
$\mathrm{Al}$ & 0 & 9 & 75 \\
$\mathrm{Fe}$ & 2 & 19 & 66 \\
$\mathrm{Ti}$ & 0 & 53 & 67 \\
$\mathrm{P}$ & 0 & 98 & 79 \\
$\mathrm{Ca}$ & 69 & 99 & 97 \\
$\mathrm{Mg}$ & 78 & 99 & 96 \\
$\mathrm{Na}$ & 95 & 100 & 96 \\
$\mathrm{~K}$ & 32 & 100 & 90 \\
$\mathrm{~S}$ & 58 & 98 & 96 \\
\hline
\end{tabular}

different. First of all, most of the potassium in both biomass fuels is readily removed by water and ammonium acetate, signifying an organic and water-soluble ion association. The wood chips show significant levels of solubility for all of the elemental species, with almost complete solubility for $\mathrm{Ca}, \mathrm{Mg}, \mathrm{Na}$, and $\mathrm{S}$. The sunflower hulls also show higher solubility in all of the elemental categories than coal, with almost complete solubility for $\mathrm{P}, \mathrm{Ca}, \mathrm{Mg}, \mathrm{Na}, \mathrm{K}$, and $\mathrm{S}$. Plant structures will contain water-soluble ions in vacuoles and cellular voids, as opposed to ion-exchangeable cations bound to organic molecules. These different dispersed ion associations may affect ash interactions during combustion. 
Bulk viscosities based on XRF analysis were determined for the coal and biomass samples and coal-biomass blends and are shown in Figure 14. This type of predictive modeling gives an estimation of fly ash particle stickiness and ash deposit sintering and strength potential. Lowermelting-point compounds and lower-viscosity liquid phases correlate with faster-growing and stronger ash deposit formation both in slagging and fouling regions of a boiler. The sunflower hulls exhibited the lowest viscosities throughout the temperature range of $500^{\circ}$ to $1500^{\circ} \mathrm{C}\left(932^{\circ}\right.$ to $2732^{\circ} \mathrm{F}$ ), while the Cordero Rojo coal and the coal-wood chip blends all exhibited the highest.

The coal-sunflower hull blends and the wood chips showed bulk viscosities that were comparable to each other throughout the temperature range.

\section{Morphology Pictures of Parent Fuels}

\section{Combustion Testing}

For the coal-biomass blends, ash deposits were grown under simulated fouling conditions in the CEPS on a water-cooled probe with a surface temperature of $540^{\circ} \mathrm{C}\left(1000^{\circ} \mathrm{F}\right)$.

The flow rate of the gas was $0.0139 \mathrm{acmm}(0.4904 \mathrm{acfm})$. Estimates of deposition rates were obtained and the deposits removed for subsequent determination of deposit strength and chemical analysis. Ash samples from the CEPS baghouse were also collected for analysis. During the tests, on-line particle-size distributions (PSDs) of entrained fly ash were obtained using a SMPS and an APS.

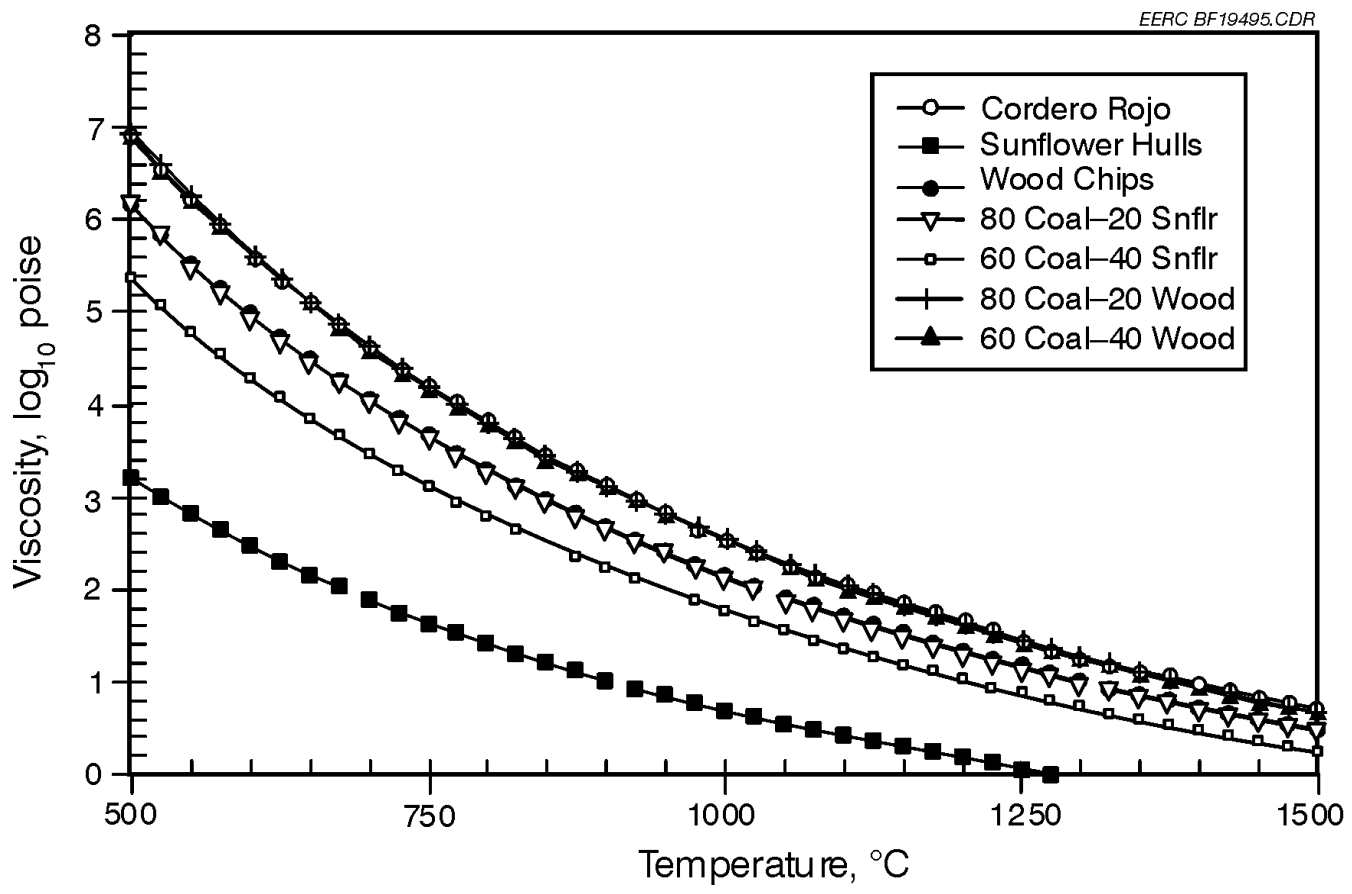

Figure 14. Summary of bulk viscosities based on XRF analysis. 


\section{Characterization of Deposit Ash}

Figures $15 \mathrm{a}-15 \mathrm{e}$ show images of the fouling deposits on the deposition probes. Visual inspection of the fouling deposits on the deposition probes reveals that the $60 \%$ coal $-40 \%$ sunflower hull blend appears to be the thickest and most densely packed fouling deposit. The $100 \%$ coal and the 80-20 coal-sunflower hull blend appear to have comparable deposits on the deposition probes. The weakest deposits appear to be the coal-wood chip blends. The progression of images shows that the sunflower blends with coal are the most sintered and thick in appearance and the wood blends with coal are the least sintered and show a more uneven ash deposition and thickness.

The deposits were submitted for crushing strength laboratory tests. Table 10 shows the growth rates, sticking fraction, and crushing strengths of fouling deposits formed from the coal-biomass blends. Although the results are somewhat sketchy, the laboratory tests seem to confirm at least the visual assessment of the $60 \%$ Cordero- $40 \%$ sunflower hull blend being the strongest and more sintered deposit. Growth rates can be deceiving because an ash deposit may grow quickly but have little strength and may even shed material that initially is reported as part of the sticking fraction. Chemical interactions between the biomass ash and the coal ash tended to increase the deposit strengths and decrease the rate of deposition.

The deposits were examined using SEMPC and XRD analysis, with results shown in Table 11. These analyses, hand in hand, give a qualitative indication of the primary and secondary crystalline phases present in the ash. In general, the major phase can be assumed to represent more than $3 \%$ of the ash by weight, and the minor phases can be assumed to represent less than $1 \%$ by weight.

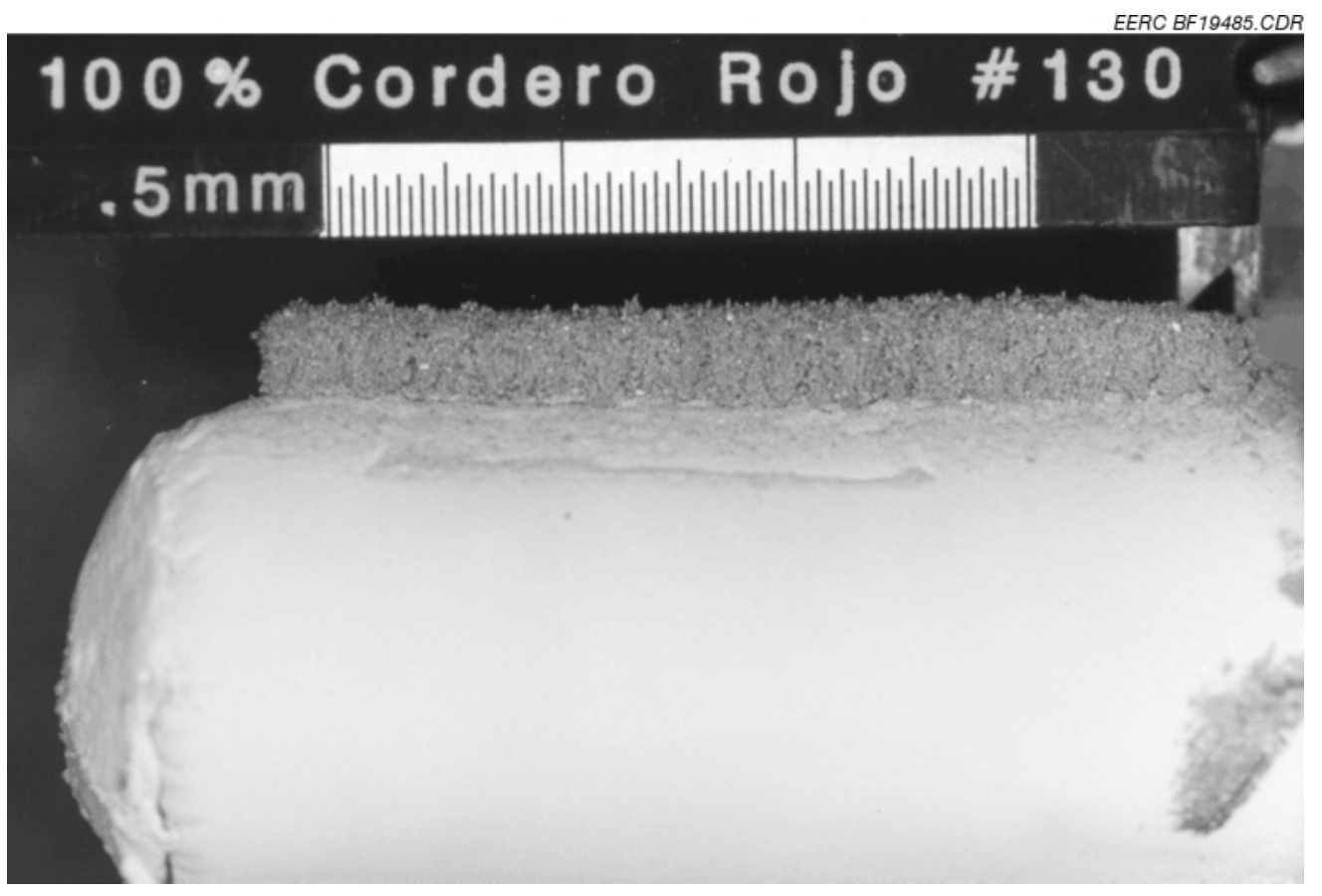

Figure 15a. Image of fouling deposit for $100 \%$ Cordero Rojo coal. 


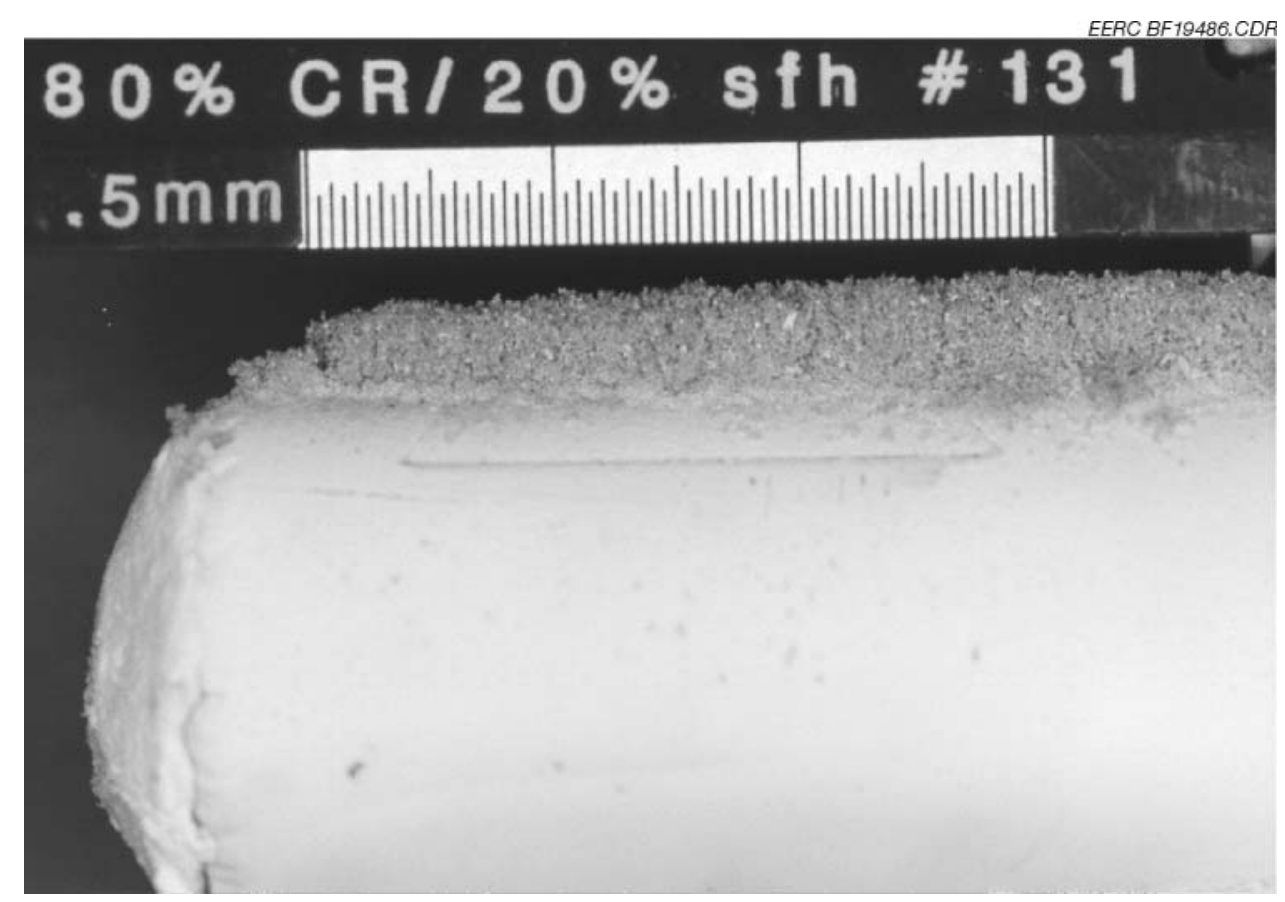

Figure $15 \mathrm{~b}$. Image of fouling deposit for $80 \%$ Cordero Rojo-20\% sunflower hull blend.

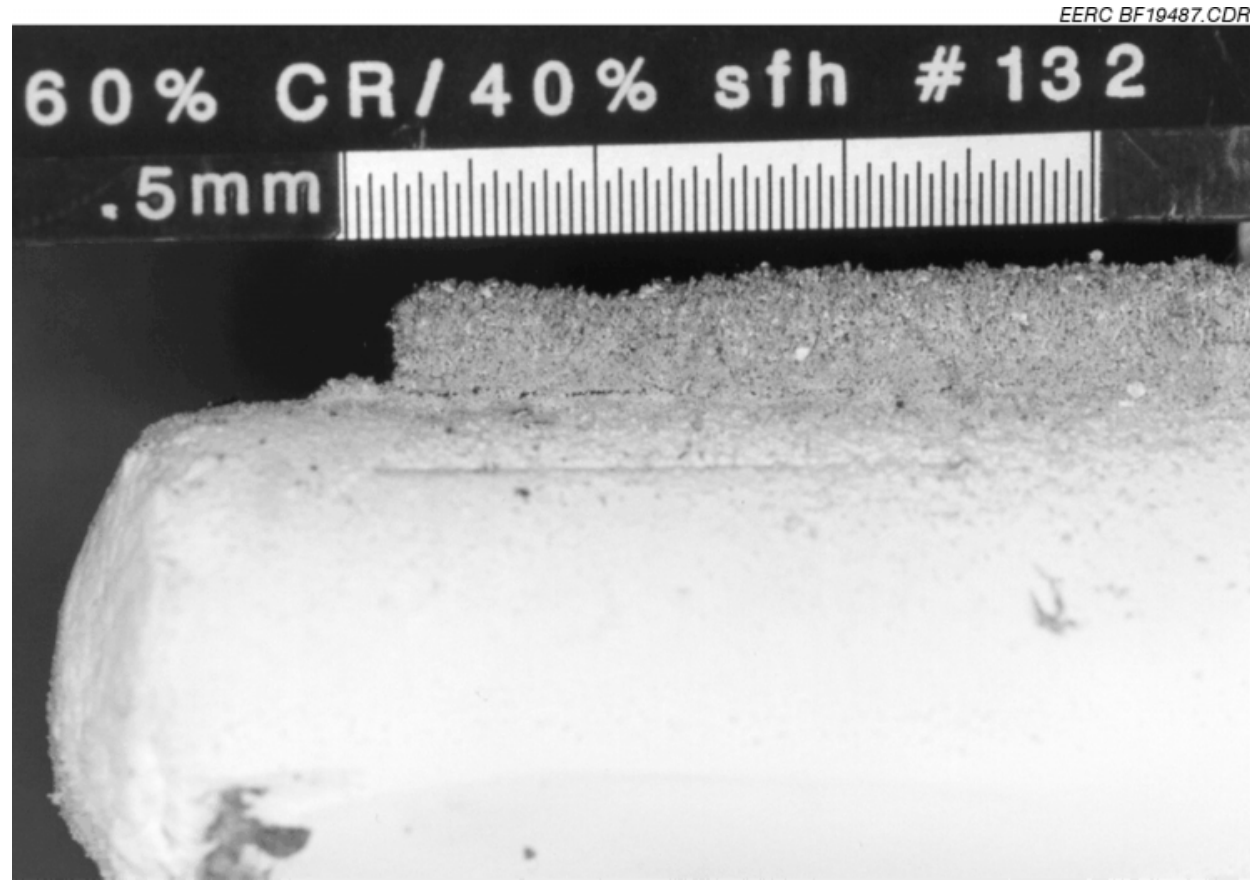

Figure $15 \mathrm{c}$. Image of fouling deposit for $60 \%$ Cordero Rojo- $40 \%$ sunflower hull blend. 


\section{$80 \%$ CR/ $20 \%$ wC \#133}

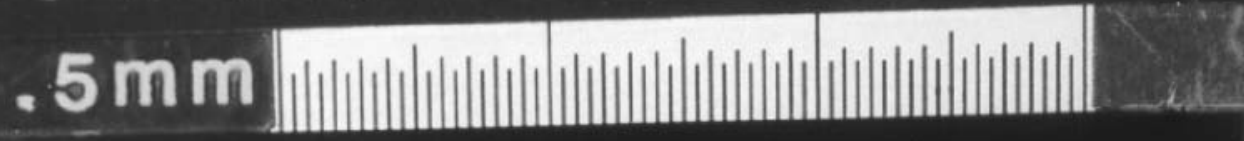

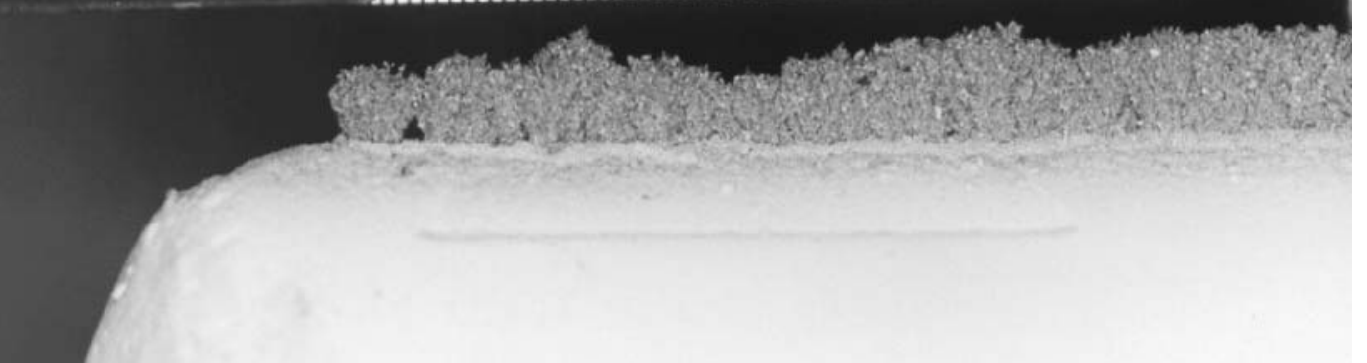

Figure 15d. Image of fouling deposit for $80 \%$ Cordero Rojo coal-20\% wood chip blend.

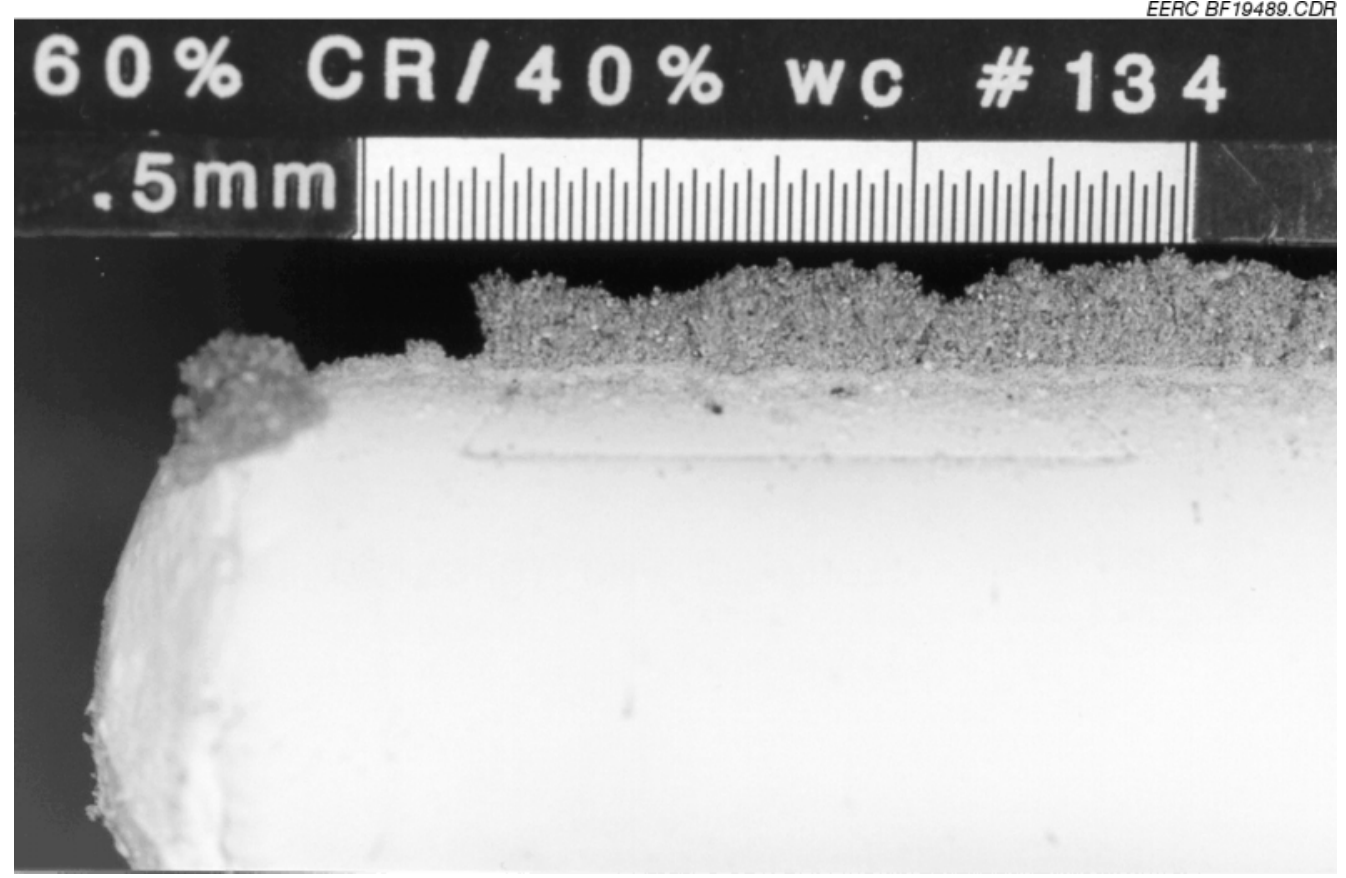

Figure 15e. Image of fouling deposit for $60 \%$ Cordero Rojo coal- $40 \%$ wood chip blend. 
Table 10. Growth Rate of Deposits, Crushing Strength, and Sticking Fraction

\begin{tabular}{lccc}
\hline Fuel & $\begin{array}{c}\text { Growth Rate, } \\
\mathrm{g} / \mathrm{min}\end{array}$ & $\begin{array}{c}\text { Deposit Strength, } \\
\mathrm{kg} / \mathrm{m}^{2}, \mathrm{psi}\end{array}$ & Sticking Fraction, \% \\
\hline 100\% Cordero Rojo & 0.0114 & $14,589(20.75)$ & 1.1 \\
80-20 Coal-Snflr & 0.0094 & $18,070(25.7)$ & 0.9 \\
60-40 Coal-Snflr & 0.0061 & $57,935(82.4)$ & 0.6 \\
80-20 Coal-Wood & 0.0089 & $18,562(26.4)$ & 0.9 \\
60-40 Coal-Wood & 0.0103 & $20,812(29.6)$ & 1 \\
\hline
\end{tabular}

Table 11. Major and Minor Crystalline Phases in Ash

\begin{tabular}{lcc}
\hline Deposit Ash & $\begin{array}{c}\text { Major } \\
\text { Crystalline } \\
\text { Phases }\end{array}$ & Minor Crystalline Phases \\
\hline $100 \%$ Cordero Rojo & Quartz & $\begin{array}{c}\text { Plagioclase, mullite, anhydrite, } \\
\text { possible cristobalite }\end{array}$ \\
60\% Cordero Rojo-40\% Wood Chips & Quartz & $\begin{array}{c}\text { Plagioclase, mullite, anhydrite, } \\
\text { diopside, cristobalite } \\
\text { Plagioclase, mullite, anhydrite, } \\
\text { diopside, cristobalite }\end{array}$ \\
60\% Cordero Rojo-20\% Wood Chips & Quartz & $\begin{array}{c}\text { Plagioclase, mullite, anhydrite, } \\
\text { diopside, cristobalite, gehlenite } \\
\text { Plagioclase, mullite, anhydrite, } \\
\text { diopside }\end{array}$ \\
\hline
\end{tabular}

Data in Table 12 indicate that the addition of sunflower hulls or wood chips to the coal significantly increases the total silicon-rich mineral content of the deposits and the illite concentration in particular. This was observed for all of the coal-biomass blends, but the effect was more pronounced for the coal-biomass blend ratios of 80-20. The addition of sunflower hulls added phosphorus and carbon-rich minerals to the deposit ash. The oxide-rich minerals increased as a function of biomass weight in the fuel. Sulfur-rich minerals decreased with the addition of biomass. This was most pronounced with the sunflower hulls.

More intense melting and interaction appear to have occurred with the sunflower hulls and coal, as evidenced by a greater mixed silicon-rich phase, the presence of gehlenite in the SEMPC and XRD analyses, and lower amounts of pure coal-sunflower minerals such as quartz and clays. The phosphorus compounds present may have acted similarly to sodium compounds in low-rank coals to effectively depress melting points and gain more pronounced liquid-phase interaction and production.

Figures 16a-16e are SEM micrographs of the fly ash. Tables 13a-13e contain the chemical analyses corresponding to the analysis points in the photographs. The micrographs indicate a higher degree of melting and interaction is occurring in the sunflower hull blends as the amount of hulls in the blend is increased when compared to the parent coal. The Cordero Rojo parent coal deposit 
Table 12. SEMPC - Mineral Classification

\begin{tabular}{|c|c|c|c|c|c|}
\hline Mineral Name & $\begin{array}{c}100 \% \text { Cordero } \\
\text { Rojo Coal }\end{array}$ & $\begin{array}{c}80 \% \text { Cordero } \\
\text { Rojo- } 20 \% \\
\text { Sunflower } \\
\text { Hulls } \\
\end{array}$ & $\begin{array}{c}60 \% \text { Cordero } \\
\text { Rojo- } 40 \% \\
\text { Sunflower } \\
\text { Hulls } \\
\end{array}$ & $\begin{array}{c}80 \% \text { Cordero } \\
\text { Rojo- } 20 \% \\
\text { Wood Chips }\end{array}$ & $\begin{array}{c}60 \% \text { Cordero } \\
\text { Rojo- } 40 \% \\
\text { Wood Chips }\end{array}$ \\
\hline \multicolumn{6}{|l|}{ Oxide-Rich } \\
\hline Aluminum Oxide & - & - & - & - & 1.4 \\
\hline Calcium Oxide & - & - & - & - & 0.7 \\
\hline Titanium Oxide & - & - & 0.4 & 1.3 & - \\
\hline Iron Oxide & - & 0.8 & 4.4 & 1.3 & 1.8 \\
\hline Mixed Oxide-Rich & 0.4 & - & 0.4 & - & 1.1 \\
\hline Total & 0.4 & 0.8 & 5.2 & 2.6 & 5 \\
\hline \multicolumn{6}{|l|}{ Sulfur-Rich } \\
\hline Mixed Sulfur-Rich & 5.4 & 0.8 & 1.6 & 3.5 & 2.1 \\
\hline \multicolumn{6}{|l|}{ Phosphorus-Rich } \\
\hline Apatite & - & - & 0.4 & - & - \\
\hline Mixed Phos.-Rich & - & 1.1 & 1.2 & - & - \\
\hline Total & 0 & 1.1 & 1.6 & 0 & 0 \\
\hline \multicolumn{6}{|l|}{ Carbon-Rich } \\
\hline Calcite & 0.4 & 2.3 & 0.8 & - & - \\
\hline Mixed Carbon-Rich & - & 0.8 & 0.4 & - & - \\
\hline Total & 0.4 & 3.1 & 1.2 & 0 & 0 \\
\hline \multicolumn{6}{|l|}{ Metal-Rich } \\
\hline Mixed Metal-Rich & 1.9 & 0.4 & 3.6 & 4 & 3.6 \\
\hline \multicolumn{6}{|l|}{ Silicon-Rich } \\
\hline Quartz & 24.1 & 20.3 & 16 & 26.1 & 14.6 \\
\hline Anorthite & 10.5 & 12.3 & 1.6 & 16.8 & 17.5 \\
\hline Leucite & - & - & 0.4 & - & - \\
\hline Kaolinite & 1.2 & - & - & 1.3 & 0.4 \\
\hline Altered Kaolinite & 5.8 & - & 2.4 & 4.4 & 1.8 \\
\hline Illite & 4.3 & 24.1 & 11.6 & 10.6 & 10 \\
\hline Montmorillonite & 3.9 & 1.1 & 0.4 & 7.1 & 6.1 \\
\hline Pyroxene & 0.4 & - & 0.8 & - & 0.7 \\
\hline Wollastonite & 1.2 & 0.4 & - & - & 1.4 \\
\hline Ca-Silicate & 0.4 & - & - & - & - \\
\hline Dicalcium Silicate & 0.4 & 0.4 & - & 0.4 & 0.4 \\
\hline Gehlenite & - & 0.8 & 0.8 & - & 1.4 \\
\hline Spurrite & 0.8 & - & - & - & - \\
\hline Mixed Silicon-Rich & 20.6 & 29.5 & 42 & 17.3 & 25 \\
\hline Total & 73.6 & 88.9 & 76 & 84 & 79.3 \\
\hline$\overline{\mathrm{AlSiCa} 1}$ & 0.8 & - & - & - & 1.4 \\
\hline $\mathrm{AlSiCa} 2$ & 0.4 & - & - & 0.9 & 0.4 \\
\hline Other & 17.5 & 5 & 10.8 & 4.9 & 8.9 \\
\hline
\end{tabular}




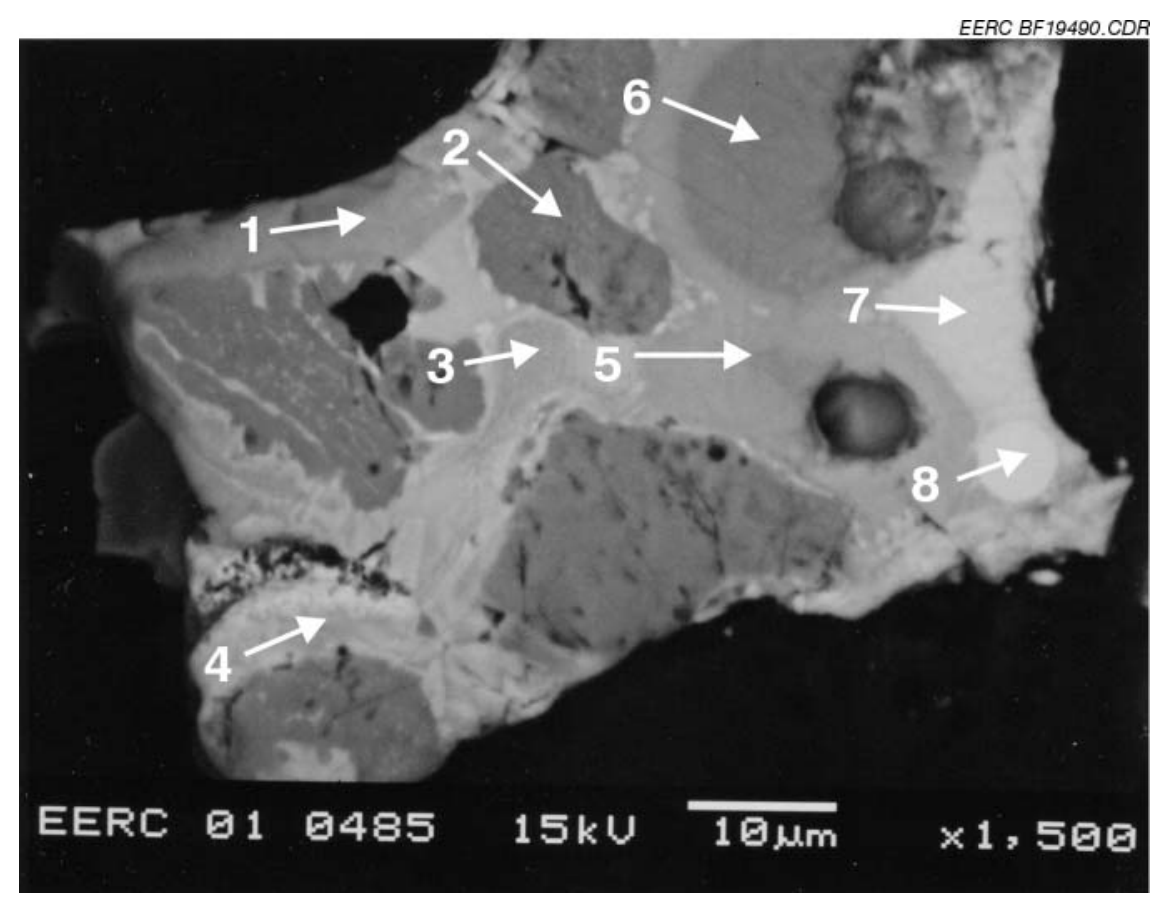

Figure 16a. SEM micrograph of 100\% Cordero Rojo deposit ash.

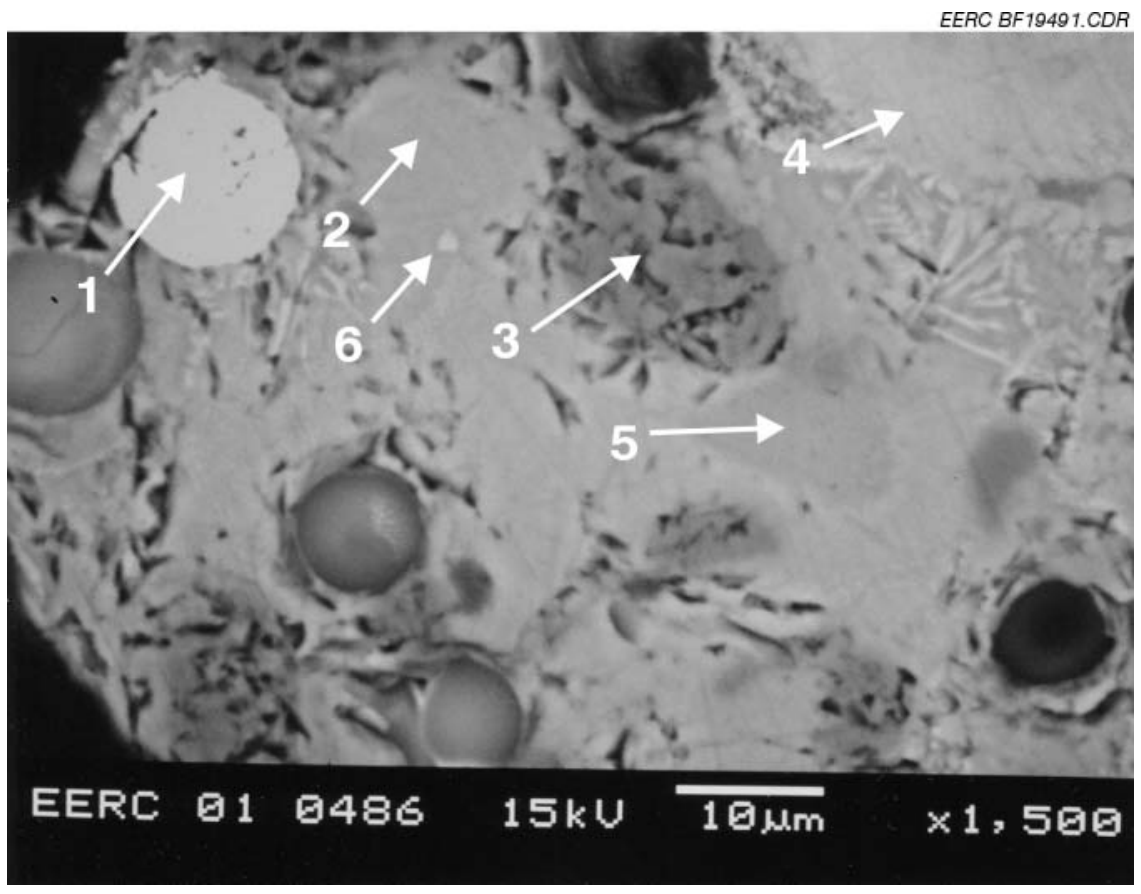

Figure 16b. SEM micrograph of 80-20 Cordero Rojo-sunflower hull deposit ash. 


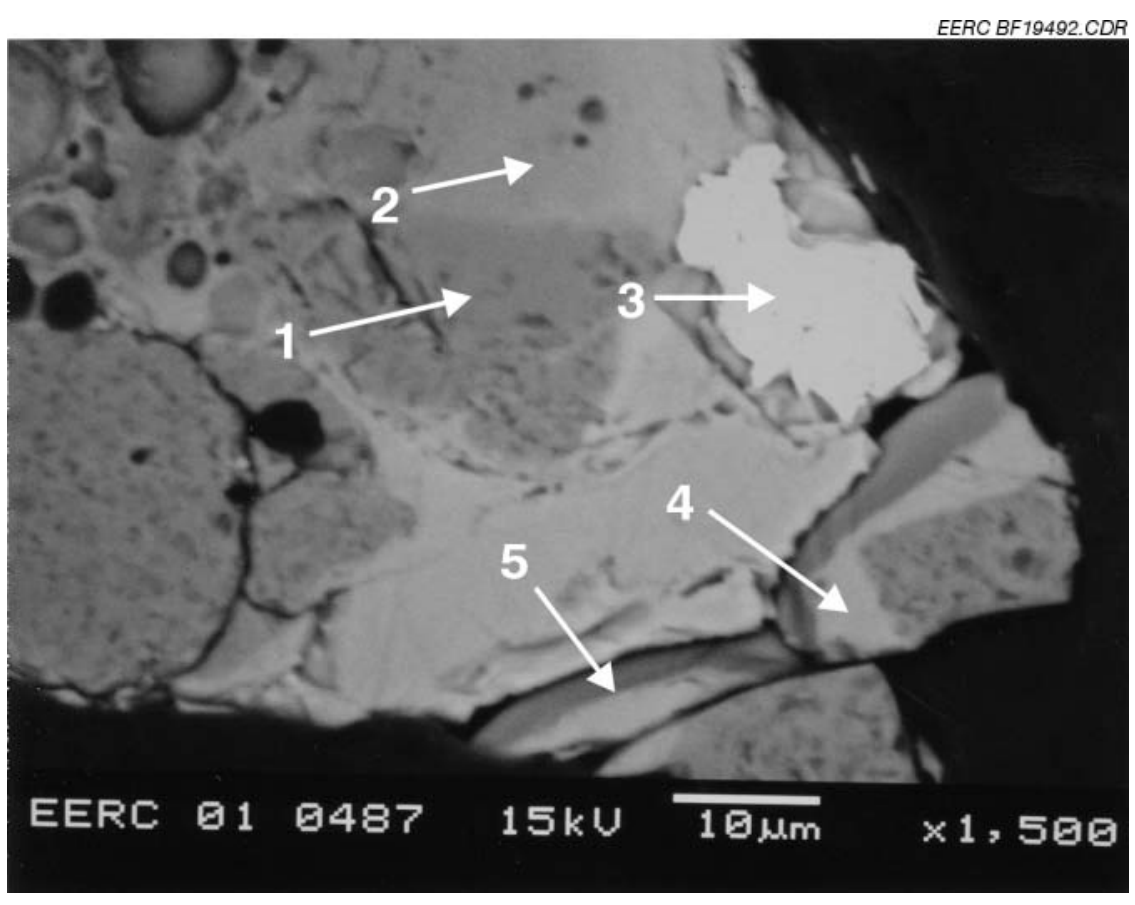

Figure 16c. SEM micrograph of 60-40 Cordero Rojo-sunflower hull deposit ash.

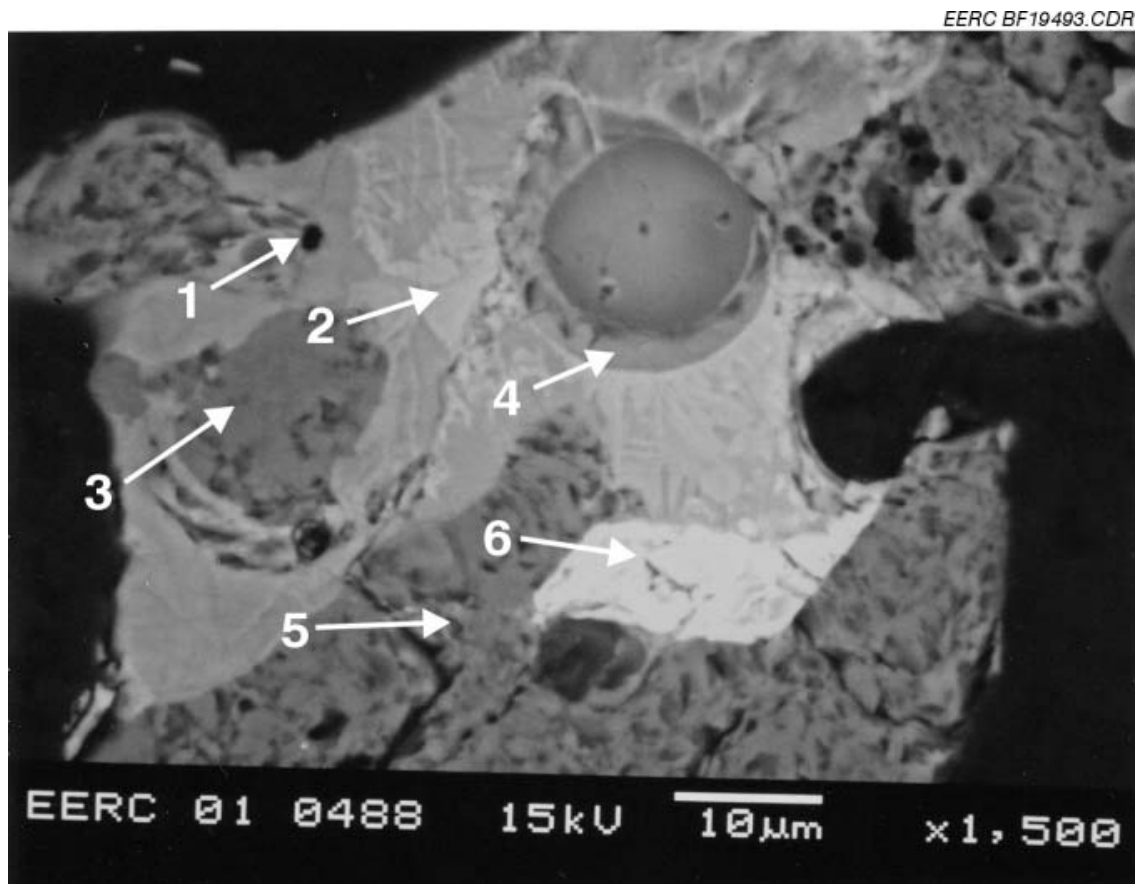

Figure 16d. SEM micrograph of 80-20 Cordero Rojo-wood chip deposit ash. 


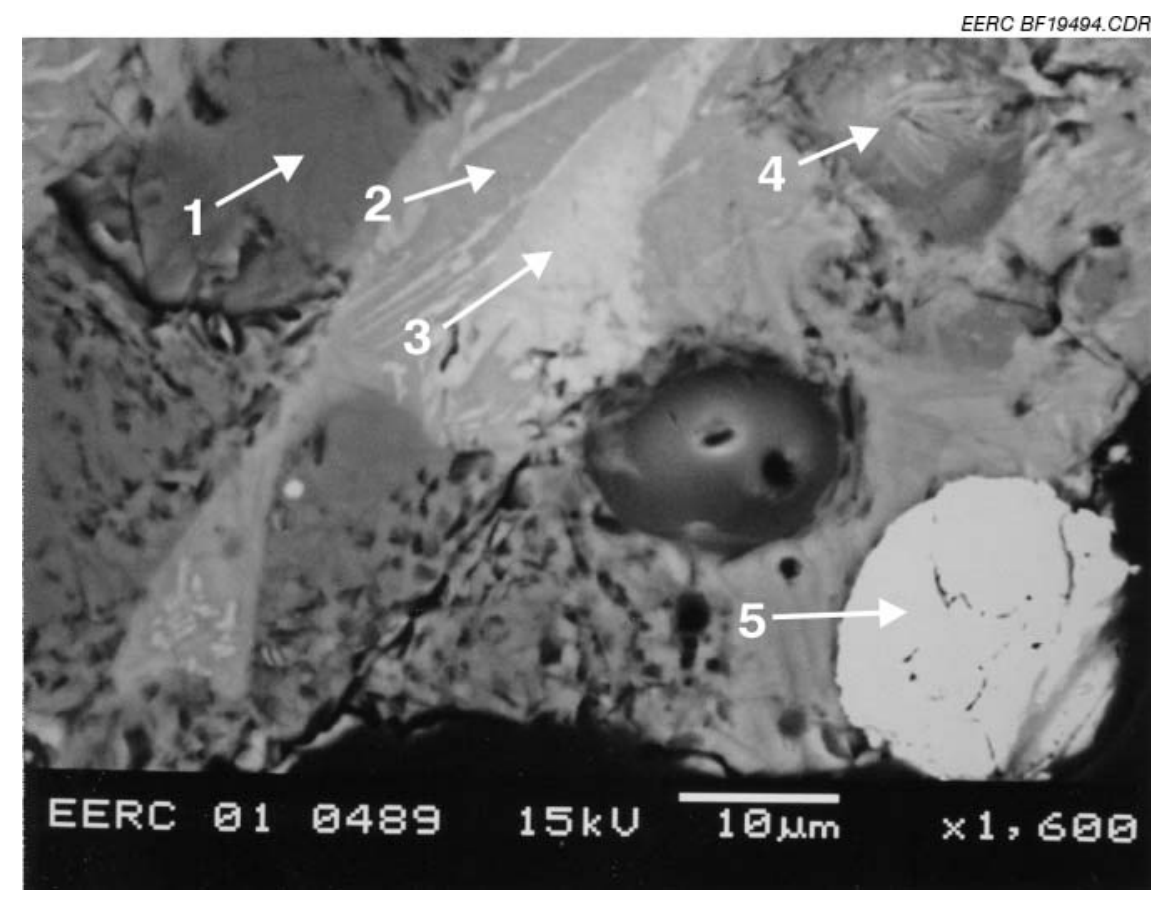

Figure 16e. SEM micrograph of 60-40 Cordero Rojo-wood chip deposit ash.

Table 13a. 100\% Cordero Rojo Deposit Ash Morphology Analysis Results, elemental wt\%

\begin{tabular}{|c|c|c|c|c|c|c|c|c|}
\hline Point: & 1 & 2 & 3 & 4 & 5 & 6 & 7 & 8 \\
\hline $\mathrm{Na}$ & 1.7 & 0.2 & 0.3 & 0.2 & 1.2 & 2.1 & 0.1 & 0.1 \\
\hline $\mathrm{Mg}$ & 0.4 & 0.3 & 0.6 & 4.1 & 0.3 & 0.4 & 4.3 & 2.0 \\
\hline $\mathrm{Al}$ & 18.0 & 0.5 & 5.3 & 13.7 & 18.9 & 24.7 & 13.0 & 3.0 \\
\hline $\mathrm{Si}$ & 28.2 & 58.8 & 32.1 & 13.6 & 27.6 & 32.1 & 9.7 & 3.0 \\
\hline $\mathrm{P}$ & 0.1 & 0.0 & 0.2 & 0.5 & 0.3 & 0.2 & 0.6 & 0.0 \\
\hline $\mathrm{S}$ & 0.0 & 0.0 & 0.1 & 1.3 & 0.1 & 0.2 & 0.0 & 0.1 \\
\hline $\mathrm{Cl}$ & 0.0 & 0.0 & 0.0 & 0.0 & 0.0 & 0.0 & 0.0 & 0.0 \\
\hline K & 0.6 & 0.0 & 0.4 & 0.0 & 0.7 & 3.8 & 0.0 & 0.2 \\
\hline $\mathrm{Ca}$ & 11.0 & 2.7 & 25.7 & 19.5 & 15.9 & 1.7 & 36.3 & 11.2 \\
\hline $\mathrm{Ti}$ & 1.1 & 0.5 & 3.1 & 1.1 & 1.2 & 0.6 & 1.1 & 55.3 \\
\hline $\mathrm{Cr}$ & 0.0 & 0.3 & 0.5 & 0.0 & 0.1 & 0.6 & 0.3 & 0.3 \\
\hline $\mathrm{Fe}$ & 1.1 & 0.7 & 3.5 & 16.5 & 2.2 & 1.6 & 11.0 & 6.2 \\
\hline $\mathrm{B}^{\mathrm{a}}$ & 0.8 & 0.4 & 1.7 & 0.4 & 1.4 & 0.0 & 2.0 & 0.0 \\
\hline $\mathrm{O}^{\mathrm{a}}$ & 37.1 & 35.8 & 26.6 & 28.8 & 30.2 & 31.9 & 21.7 & 18.8 \\
\hline Total & 100.0 & 100.0 & 100.0 & 100.0 & 100.0 & 100.0 & 100.0 & 100.0 \\
\hline
\end{tabular}

${ }^{a}$ Determined by difference. 
Table 13b. 80-20 Cordero Rojo-Sunflower Hull Deposit Ash Morphology Analysis Results, elemental wt\%

\begin{tabular}{lrrrrrr}
\hline Point: & 1 & \multicolumn{1}{c}{2} & \multicolumn{1}{c}{3} & \multicolumn{1}{c}{4} & \multicolumn{1}{c}{5} & \multicolumn{1}{c}{6} \\
\hline $\mathrm{Na}$ & 0.1 & 0.9 & 0.1 & 0.2 & 1.4 & 0.5 \\
$\mathrm{Mg}$ & 0.0 & 0.4 & 0.0 & 5.3 & 0.6 & 2.0 \\
$\mathrm{Al}$ & 0.2 & 15.7 & 0.0 & 8.2 & 14.9 & 11.3 \\
$\mathrm{Si}$ & 0.3 & 28.0 & 62.0 & 8.9 & 28.2 & 26.9 \\
$\mathrm{P}$ & 0.0 & 0.0 & 0.0 & 8.3 & 0.3 & 0.2 \\
$\mathrm{~S}$ & 0.3 & 0.0 & 0.0 & 0.2 & 0.2 & 0.0 \\
$\mathrm{Cl}$ & 0.0 & 0.1 & 0.0 & 0.0 & 0.1 & 0.0 \\
$\mathrm{~K}$ & 0.1 & 14.6 & 0.0 & 0.4 & 13.9 & 8.7 \\
$\mathrm{Ca}$ & 0.7 & 4.0 & 0.0 & 35.6 & 4.4 & 10.5 \\
$\mathrm{Ti}$ & 0.0 & 5.2 & 0.4 & 0.5 & 3.8 & 7.2 \\
$\mathrm{Cr}$ & 0.0 & 0.0 & 0.0 & 0.2 & 0.0 & 0.1 \\
$\mathrm{Fe}$ & 91.0 & 0.7 & 0.0 & 2.6 & 1.9 & 2.6 \\
$\mathrm{Ba}$ & 0.0 & 0.3 & 0.0 & 0.0 & 1.8 & 0.0 \\
$\mathrm{O}$ & 7.4 & 30.2 & 37.5 & 29.8 & 28.5 & 29.8 \\
Total & 100 & 100.0 & 100 & 100 & 100 & 100 \\
\hline
\end{tabular}

${ }^{a}$ Determined by difference.

Table 13c. 60-40 Cordero Rojo-Sunflower Hull Deposit Ash Morphology Analysis Results, elemental wt\%

\begin{tabular}{lrrrrr}
\hline Point: & \multicolumn{1}{c}{1} & \multicolumn{1}{c}{2} & 3 & \multicolumn{1}{c}{4} & \multicolumn{1}{c}{5} \\
\hline $\mathrm{Na}$ & 0.0 & 0.7 & 0.3 & 0.6 & 0.7 \\
$\mathrm{Mg}$ & 0.0 & 3.0 & 0.2 & 2.9 & 3.3 \\
$\mathrm{Al}$ & 0.1 & 19.6 & 0.1 & 16.6 & 17.5 \\
$\mathrm{Si}$ & 60.9 & 22.7 & 0.2 & 24.7 & 20.9 \\
$\mathrm{P}$ & 0.1 & 0.0 & 0.2 & 0.4 & 0.0 \\
$\mathrm{~S}$ & 0.0 & 0.1 & 0.1 & 0.0 & 0.1 \\
$\mathrm{Cl}$ & 0.0 & 0.0 & 0.1 & 0.0 & 0.0 \\
$\mathrm{~K}$ & 0.1 & 6.7 & 0.0 & 7.8 & 4.8 \\
$\mathrm{Ca}$ & 0.5 & 15.4 & 0.3 & 14.1 & 14.1 \\
$\mathrm{Ti}$ & 0.0 & 1.0 & 0.0 & 1.1 & 0.7 \\
$\mathrm{Cr}$ & 0.2 & 0.0 & 0.0 & 0.1 & 0.3 \\
$\mathrm{Fe}$ & 0.7 & 1.7 & 86.4 & 0.8 & 0.7 \\
$\mathrm{Ba}$ & 0.2 & 0.7 & 0.0 & 0.9 & 0.5 \\
$\mathrm{O}^{\mathrm{a}}$ & 37.3 & 28.4 & 12.4 & 30.2 & 36.5 \\
Total & 100 & 100.0 & 100 & 100 & 100 \\
\hline
\end{tabular}

${ }^{a}$ Determined by difference. 
Table 13d. 80-20 Cordero Rojo-Wood Chip Deposit Ash Morphology Analysis Results, elemental wt\%

\begin{tabular}{lrrrrrr}
\hline Point: & \multicolumn{1}{c}{1} & \multicolumn{1}{c}{2} & \multicolumn{1}{c}{3} & \multicolumn{1}{c}{4} & \multicolumn{1}{c}{5} & \multicolumn{1}{c}{6} \\
\hline $\mathrm{Na}$ & 2.0 & 0.2 & 0.0 & 3.0 & 0.1 & 0.0 \\
$\mathrm{Mg}$ & 0.8 & 5.5 & 0.1 & 0.5 & 0.0 & 0.0 \\
$\mathrm{Al}$ & 14.9 & 5.5 & 0.1 & 18.2 & 0.2 & 0.2 \\
$\mathrm{Si}$ & 29.8 & 23.0 & 58.6 & 27.9 & 57.5 & 0.4 \\
$\mathrm{P}$ & 0.0 & 0.1 & 0.2 & 0.0 & 0.1 & 0.0 \\
$\mathrm{~S}$ & 0.1 & 0.3 & 0.0 & 0.0 & 0.1 & 0.0 \\
$\mathrm{Cl}$ & 0.0 & 0.1 & 0.0 & 0.1 & 0.0 & 0.0 \\
$\mathrm{~K}$ & 0.8 & 0.1 & 0.1 & 3.6 & 0.2 & 0.0 \\
$\mathrm{Ca}$ & 12.5 & 23.6 & 0.1 & 6.9 & 0.0 & 0.6 \\
$\mathrm{Ti}$ & 0.4 & 2.9 & 0.0 & 0.7 & 0.2 & 74.6 \\
$\mathrm{Cr}$ & 0.0 & 0.0 & 0.0 & 0.0 & 0.2 & 0.0 \\
$\mathrm{Fe}$ & 3.5 & 9.7 & 0.0 & 1.7 & 0.3 & 0.8 \\
$\mathrm{Ba}$ & 0.9 & 0.0 & 0.0 & 0.4 & 0.0 & 0.0 \\
$\mathrm{O}^{\mathrm{a}}$ & 34.3 & 28.9 & 40.9 & 37.2 & 41.0 & 23.3 \\
Total & 100 & 100.0 & 100 & 100 & 100 & 100 \\
\hline
\end{tabular}

${ }^{\mathrm{a}}$ Determined by difference.

Table 13e. 60-40 Cordero Rojo-Wood Chip Deposit Ash Morphology Analysis Results, elemental wt\%

\begin{tabular}{lrrrrr}
\hline Point: & \multicolumn{1}{c}{1} & \multicolumn{1}{c}{2} & \multicolumn{1}{c}{3} & \multicolumn{1}{c}{4} & \multicolumn{1}{c}{5} \\
\hline $\mathrm{Na}$ & 0.0 & 0.1 & 0.1 & 0.8 & 0.2 \\
$\mathrm{Mg}$ & 0.0 & 3.5 & 4.7 & 0.4 & 0.0 \\
$\mathrm{Al}$ & 0.0 & 10.5 & 8.1 & 15.8 & 0.1 \\
$\mathrm{Si}$ & 61.4 & 13.8 & 15.7 & 27.2 & 0.1 \\
$\mathrm{P}$ & 0.0 & 0.3 & 0.6 & 0.2 & 0.0 \\
$\mathrm{~S}$ & 0.0 & 0.0 & 0.1 & 0.1 & 0.0 \\
$\mathrm{Cl}$ & 0.0 & 0.1 & 0.0 & 0.0 & 0.0 \\
$\mathrm{~K}$ & 0.0 & 0.1 & 0.0 & 0.6 & 0.2 \\
$\mathrm{Ca}$ & 0.2 & 37.6 & 37.5 & 19.7 & 0.3 \\
$\mathrm{Ti}$ & 0.1 & 2.2 & 1.8 & 0.8 & 0.0 \\
$\mathrm{Cr}$ & 0.2 & 0.0 & 0.0 & 0.3 & 0.0 \\
$\mathrm{Fe}$ & 0.0 & 8.3 & 7.2 & 4.1 & 86.8 \\
$\mathrm{Ba}$ & 0.5 & 1.3 & 0.2 & 0.8 & 0.0 \\
$\mathrm{O}^{\mathrm{a}}$ & 37.6 & 22.3 & 23.9 & 29.2 & 12.4 \\
Total & 100 & 100 & 100 & 100 & 100 \\
\hline
\end{tabular}

${ }^{a}$ Determined by difference.

shows a much more discrete particle morphology than the blends. The sunflower hull blend deposits also show an enrichment in potassium and phosphorus. The glue in the deposit switches from a $\mathrm{Ca}-\mathrm{Al}-\mathrm{Si}$ and a $\mathrm{Ca}-\mathrm{Fe}-\mathrm{Al}-\mathrm{Si}$ to these same materials with an increased level of potassium and phosphorus. The addition of potassium and phosphorus to a calcium aluminosilicate will tend to lower the melting point of the material. This indicates the volatile phosphorus and potassium are 
participating in the deposit growth and strength development by lowering the melting point of the major phases in the deposit. The wood waste blend deposits, on the other hand, show very little change from the parent Cordero Rojo deposits. This is probably due in large part to the low ash content of the wood waste having little ability to affect the morphology and composition of the deposit.

\section{Emissions Analysis}

Emissions data are presented in Table 14 for all of the coal-biomass blends. All of the coal-biomass blends exhibited a decrease in $\mathrm{SO}_{2}$. This is directly due to the replacement of the higher-sulfur-content coal with a lower-sulfur-content biomass.

Table 14. Emissions Data for CEPS Runs

\begin{tabular}{lccccc}
\hline Gas Analysis & $\begin{array}{c}100 \% \text { Cordero } \\
\text { Rojo }\end{array}$ & $\begin{array}{c}80-20 \\
\text { Coal-Snflr }\end{array}$ & $\begin{array}{c}60-40 \\
\text { Coal-Wood }\end{array}$ & $\begin{array}{c}80-20 \\
\text { Coal-Wood }\end{array}$ & $\begin{array}{c}60-40 \\
\text { Coal-Wood }\end{array}$ \\
\hline $\mathrm{O}_{2}, \%$ & 9.4 & 9.3 & 9 & 9.3 & 9.8 \\
$\mathrm{CO}_{2}, \%$ & 16 & 16 & 16 & 16 & 16 \\
$\mathrm{CO}, \mathrm{ppm}$ & 30 & 75 & 83 & 24 & 59 \\
$\mathrm{SO}_{2}, \mathrm{ppm}$ & 630 & 605 & 485 & 569 & 496 \\
$\mathrm{NO}_{2}, \mathrm{ppm}$ & 1409 & 1498 & 1466 & 1499 & 1518 \\
$\mathrm{NO}_{2}, \mathrm{ppm}$ & 92 & 36 & 55 & 36 & 25 \\
$\mathrm{NO}_{\mathrm{x}}, \mathrm{ppm}$ & 1500 & 1535 & 1522 & 1535 & 1544 \\
\hline
\end{tabular}

\section{Characterization of Fly Ash}

Table 15 shows the CCSEM analysis of the fly ash for the coal-biomass blends. The results of CCSEM analysis of fly ash were ambiguous because of the very large amount of material categorized as "unclassified." Such material does not fit the composition criteria established for specific coal mineral phases and appears to be the result of mixed ash material containing both coal and biomass inorganic components. Table 16 presents the average elemental composition for the unclassified material. The unclassified material is normally the result of intermixing and reaction of various minerals and other elements in the burning fuel char, resulting in more of an amorphous agglomerate of chemistries. The $60 \%$ coal $-40 \%$ sunflower blend fly ash shows the highest amount of potassium and potassium silicate, which may correspond to slightly more lower-melting-point liquid phases for this fly ash. This would make the ash more sticky than the other ashes and more problematic for ash deposition.

All of the fuel blends contain substantial amounts of calcium, chlorine, alumina, and silica. While the two sunflower blends were comparable to each other, the two wood chip blends exhibited substantial differences. The sunflower hull blend fly ash exhibited an enrichment in potassium and 
Table 15. CCSEM Analysis of Fly Ash

\begin{tabular}{lccccc}
\hline & & $80 \%$ Coal- & $60 \%$ Coal- & $80 \%$ Coal- & 60\% Coal- \\
CCSEM Analysis & Coal & $20 \%$ Snflr & $40 \%$ Snflr & $20 \%$ Wood & $40 \%$ Wood \\
\hline Quartz & 2.3 & 2.6 & 3.2 & 6 & 1.3 \\
Iron Oxide & 0.4 & 0 & 0.4 & 0.5 & 0.1 \\
K Al-Silicate & 0.1 & 4.1 & 5.9 & 0.5 & 0.3 \\
Ca Al-Silicate & 1.4 & 0.9 & 0.9 & 7.6 & 2.2 \\
Mixed Al-Sicia & 2.9 & 0.2 & 0 & 4.7 & 1.4 \\
Gypsum/Al-Silicate & 10.7 & 0 & 0 & 0.1 & 0 \\
Si-Rich & 0.4 & 1 & 1 & 1.3 & 0.2 \\
Unclassified & 78.8 & 90.4 & 87.8 & 74.3 & 93.5 \\
\hline
\end{tabular}

Table 16. Elemental Composition of Unclassified Content

\begin{tabular}{lccccc}
\hline & $\begin{array}{c}\text { 80\% Cordero } \\
\text { Rojo-20\% } \\
\text { Cordero } \\
\text { Rojo }\end{array}$ & $\begin{array}{c}\text { Sunflower } \\
\text { Hulls }\end{array}$ & $\begin{array}{c}\text { Rojo-40\% } \\
\text { Sunflower } \\
\text { Hulls }\end{array}$ & $\begin{array}{c}\text { 80\% Cordero } \\
\text { Rojo-20\% } \\
\text { Wood Chips }\end{array}$ & $\begin{array}{c}\text { 60\% Cordero } \\
\text { Rojo-40\% } \\
\text { Wood Chips }\end{array}$ \\
\hline $\mathrm{Si}$ & 13.9 & 15.4 & 14.4 & 13.1 & 9.9 \\
$\mathrm{Al}$ & 14.6 & 14.5 & 13.5 & 16.2 & 10.2 \\
$\mathrm{Fe}$ & 7.7 & 6.9 & 6.5 & 9.8 & 5.6 \\
$\mathrm{Ti}$ & 1.6 & 1.5 & 1.6 & 2.2 & 1.3 \\
$\mathrm{P}$ & 1.8 & 2 & 2.5 & 1.7 & 25.5 \\
$\mathrm{Ca}$ & 31.9 & 29.7 & 28 & 40.8 & 3 \\
$\mathrm{Mg}$ & 3.7 & 4 & 3.9 & 4.7 & 0.6 \\
$\mathrm{Na}$ & 1 & 0.8 & 0.8 & 0.6 & 1.1 \\
$\mathrm{~K}$ & 0.9 & 3.8 & 6.1 & 0.9 & 3.2 \\
$\mathrm{~S}$ & 4.4 & 2.8 & 3.3 & 1.5 & 36.7 \\
$\mathrm{Ba}$ & 1.6 & 1.5 & 1.5 & 1.5 & \\
$\mathrm{Cl}$ & 17 & 17 & 17.8 & 6.9 & \\
\hline & & & & & 3.5 \\
\hline
\end{tabular}


phosphorus as would be expected based on the biomass bulk ash chemistry. The $20 \%$ wood chip blend showed substantially higher amounts of silica, alumina, iron, and calcium, with much lower chlorine content than the $40 \%$ wood chip blend.

The fly ash was analyzed for the PSD greater than $1 \mu \mathrm{m}$ by CCSEM. Figure 17 shows the PSD and the cumulative PSD for the fly ash obtained from the combustion tests. The size distribution for all of the coal-biomass blends was finer than the size distribution for the Cordero Rojo coal. The typical size of the fly ash for the coal-biomass blends was between 2 and $8 \mu \mathrm{m}$, while the typical size of the fly ash for the Cordero Rojo coal was distributed between 2 and $16 \mu \mathrm{m}$. The size distribution for all of the fuel blends tended to exhibit two peaks. Most of the coal-biomass blends showed a maximum peak between 3 and $5 \mu \mathrm{m}$ and a secondary peak between 6 and $8 \mu \mathrm{m}$. The Cordero Rojo coal gave a primary peak at $4.3 \mu \mathrm{m}$ and a secondary peak at $9 \mu \mathrm{m}$. The sunflower hull blends show the finest PSD, probably due to vapor phosphates, potassium sulfates, potassium chlorides, and fine silica.
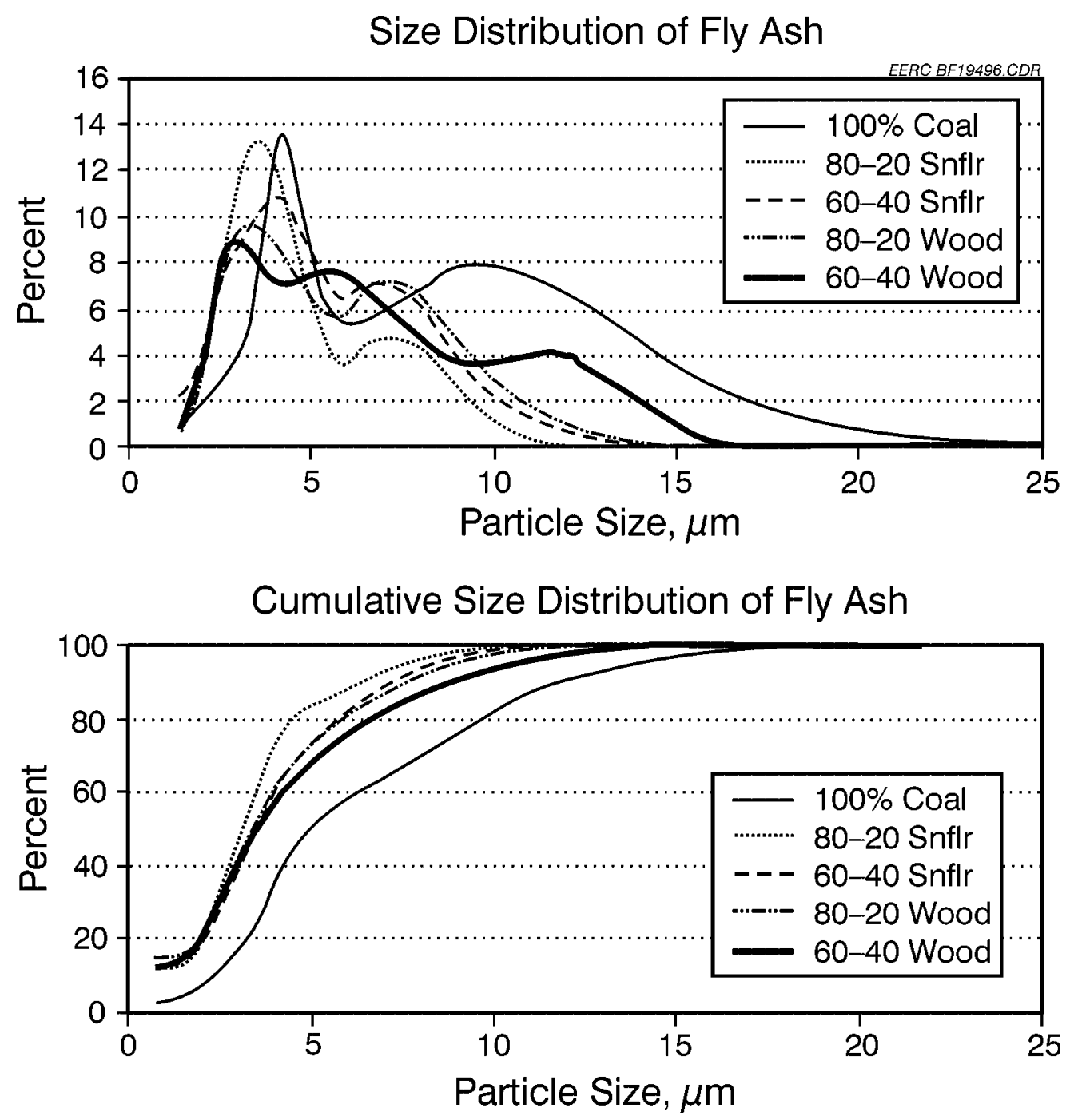

Figure 17. PSD of the fly ash from the combustion tests. 
Figures 18 and 19 show the cumulative submicron size distribution of the coal-sunflower hull blends and coal-wood blends, respectively. The wood blends show a slight increase in particle size, while the hulls exhibit an overall decrease in the submicron particle size. The increased size of the wood particles is more than likely due to interaction of the ash from the biomass with that of the coal. The decrease shown in the hull blends is reflective of the ash fusion test which indicated a large amount of volatile inorganic material. This vapor-phase material is then apparently condensing out of the gas at lower-temperature regions in the system to form submicron particles. Individual SEM photos and morphology with point analyses of fly ash grains for the coal and coal-biomass blends in Figures 20a-20e, reveal the biomodal nature of the fly ash. Tables $17 \mathrm{a}-17 \mathrm{e}$ contain the chemical analyses corresponding to the analysis points in the photographs. Also, the individual chemistries are for select individual fly ash particles, and it is apparent that some of the more volatile elements such as phosphorus, sulfur, and potassium are remaining with the particulate fraction of the flue gas. Also, it appears that phosphorus is correlating with calcium concentration and may be associated as a high-temperature form of calcium phosphate.

\section{Predictive Modeling}

Predictive modeling of the coal samples, biomass samples, and coal-biomass blends was performed with the PCQUEST model developed at the EERC. This model provides ash behavior indices for a variety of ash-related problem areas, and the indices are listed in Table 18. Eight indices are calculated: grindability, high-temperature fouling, low-temperature fouling, slagging, slag tapping, sootblowing, erosion, and opacity, either for a specific power station using the input boiler parameters or for a generic boiler.

PCQUEST results, consisting of index values from 0-100, with higher numbers signifying worse or more intense ash quality impacts, showed that the Cordero coal and parent sunflower hulls $(100 \%)$ were predicted to produce low or moderate slagging and fouling deposits in the PCQUEST fouling index (FI) range of 32-39. The wood chips were predicted to produce low slagging $(\mathrm{FI}=20)$ and higher moderate fouling $(\mathrm{FI}=47)$. Blends of the biomass with Cordero coal, however, show slightly higher slagging and fouling deposits for the Cordero-sunflower blends compared to the Cordero-wood chip blends. Sunflower hulls and Cordero-sunflower hull blends also showed higher potential opacity numbers.

The results of FACT modeling are presented in Appendix B. The graphs in Figure B1 of Appendix B show the liquid-solid-phase diagrams as a function of temperature. The graphs in Figure B2 show the viscosity of the liquid phases of the fuels as a function of temperature. Both the viscosity and the amount of liquid phases present are important in predicting the ash deposition rate that can occur as a function of ash fed into the boiler. For each fuel blend, the percentage of the liquid phase and the viscosity of the liquid at $1500^{\circ} \mathrm{C}$ were used to calculate the predicted ash deposition rate per kilogram of ash fed, using the following formula:

Deposition rate in grams deposited per kilogram ash fed $=$ $2.691 \times\left(\right.$ percent liquid phases/abs[ $\left[\log _{10}\right.$ viscosity $\left.]\right)-3.657$

Table 19 gives the potential ash deposition rate as both a function of ash and as a function of Btu. These values are best used as a relative measure of the fouling rate potential for each fuel blend. According to the FACT thermodynamic model, the fouling rate is highest for sunflower hulls and 


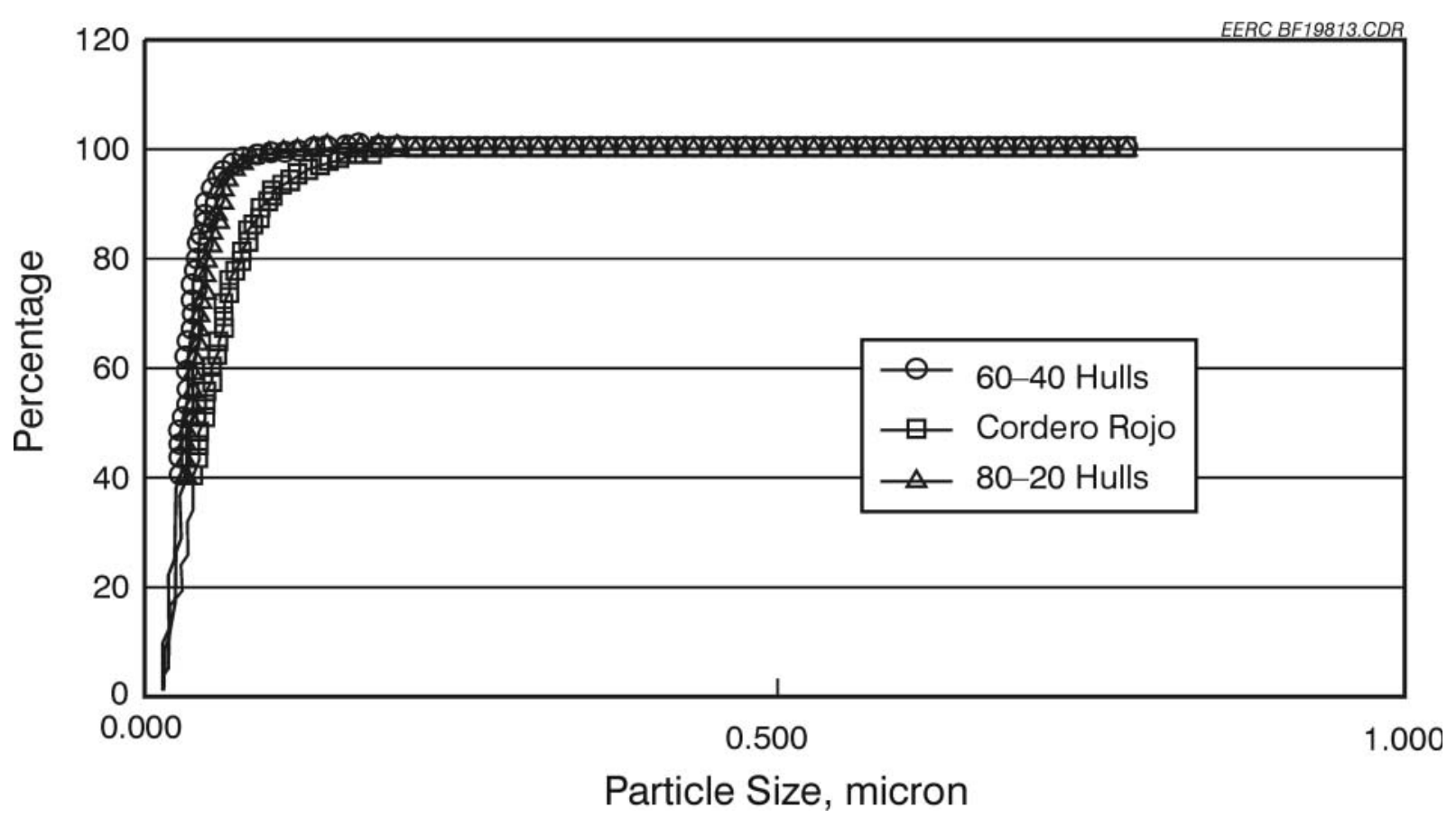

Figure 18. Cumulative submicron combustion ash PSD for coal and coal-sunflower hull blends.

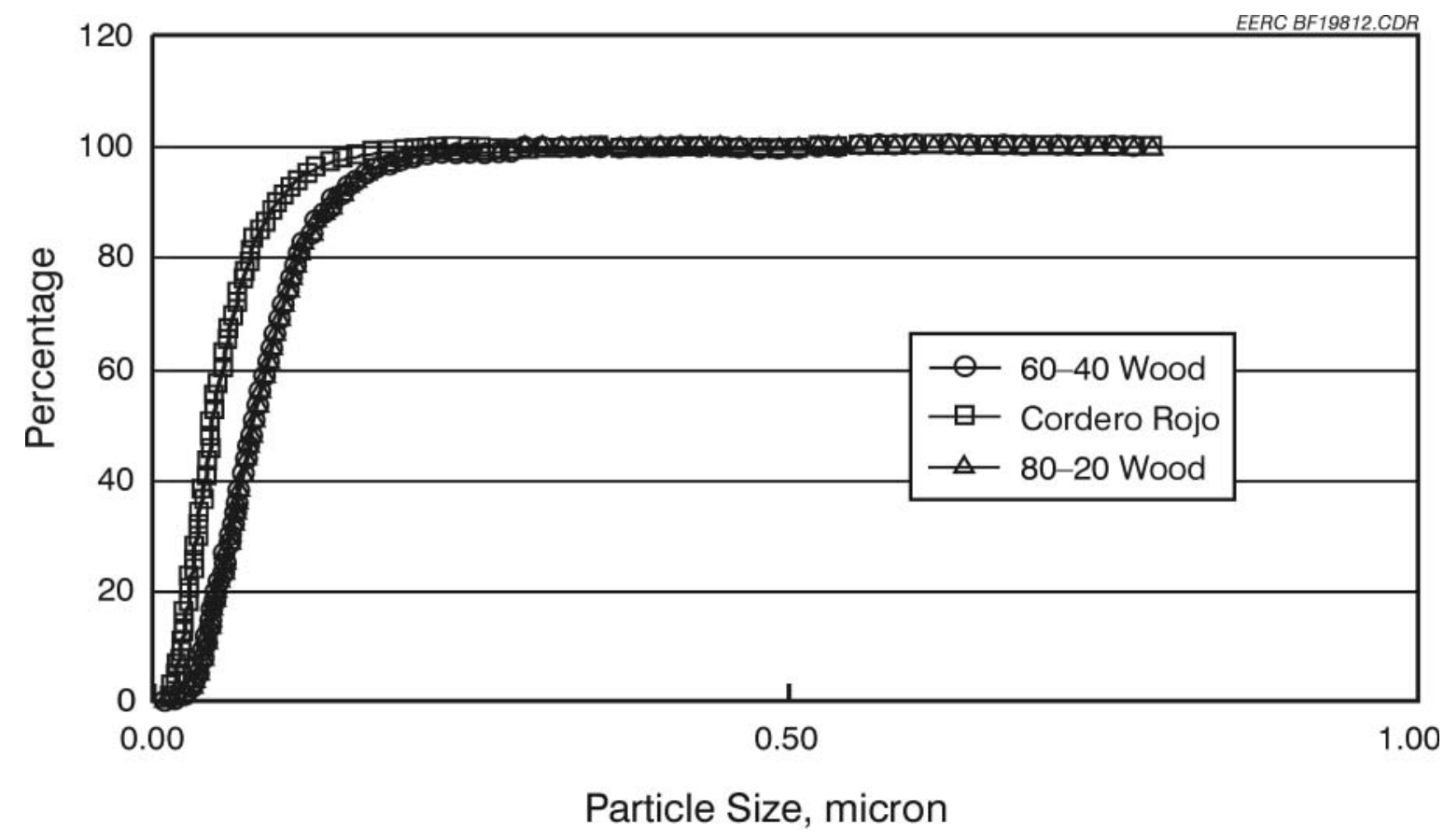

Figure 19. Cumulative submicron combustion ash PSD for coal and coal-wood blends. 


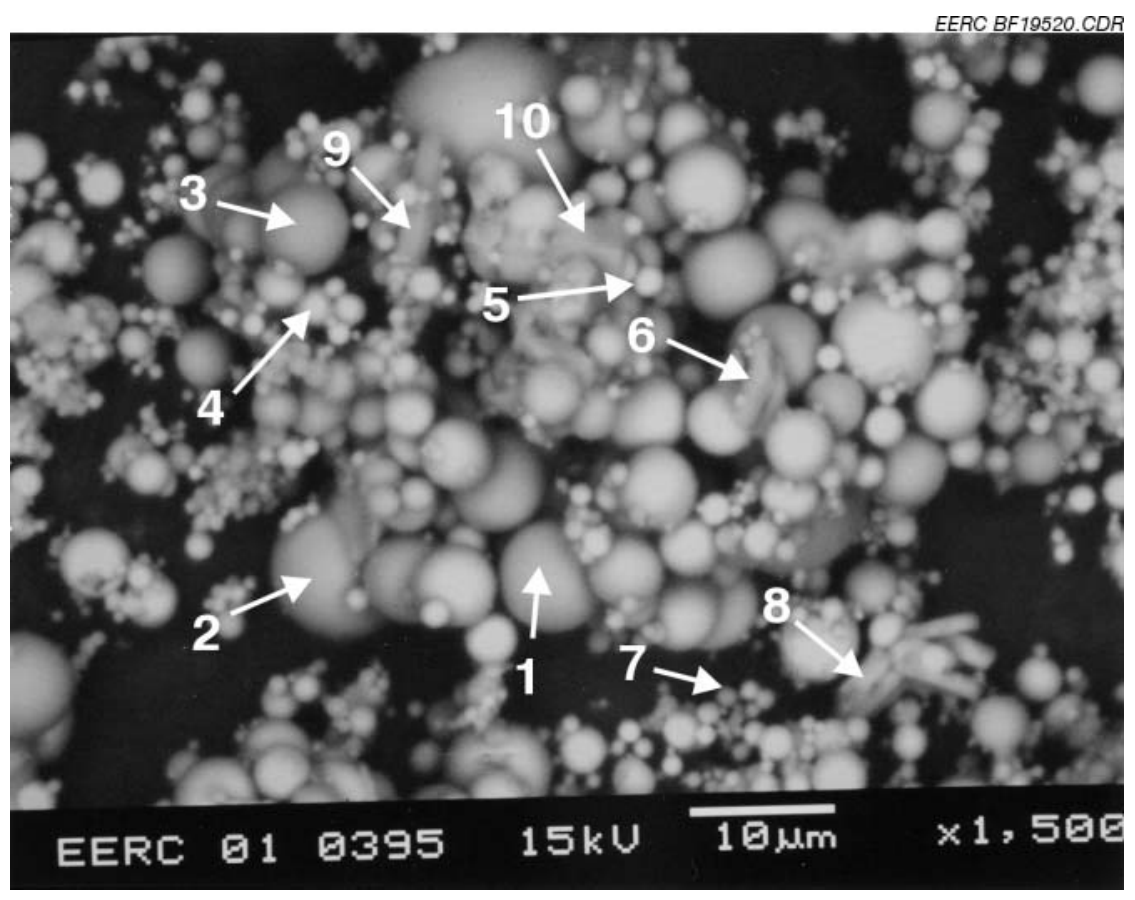

Figure 20a. SEM micrograph of $100 \%$ Cordero Rojo fly ash.

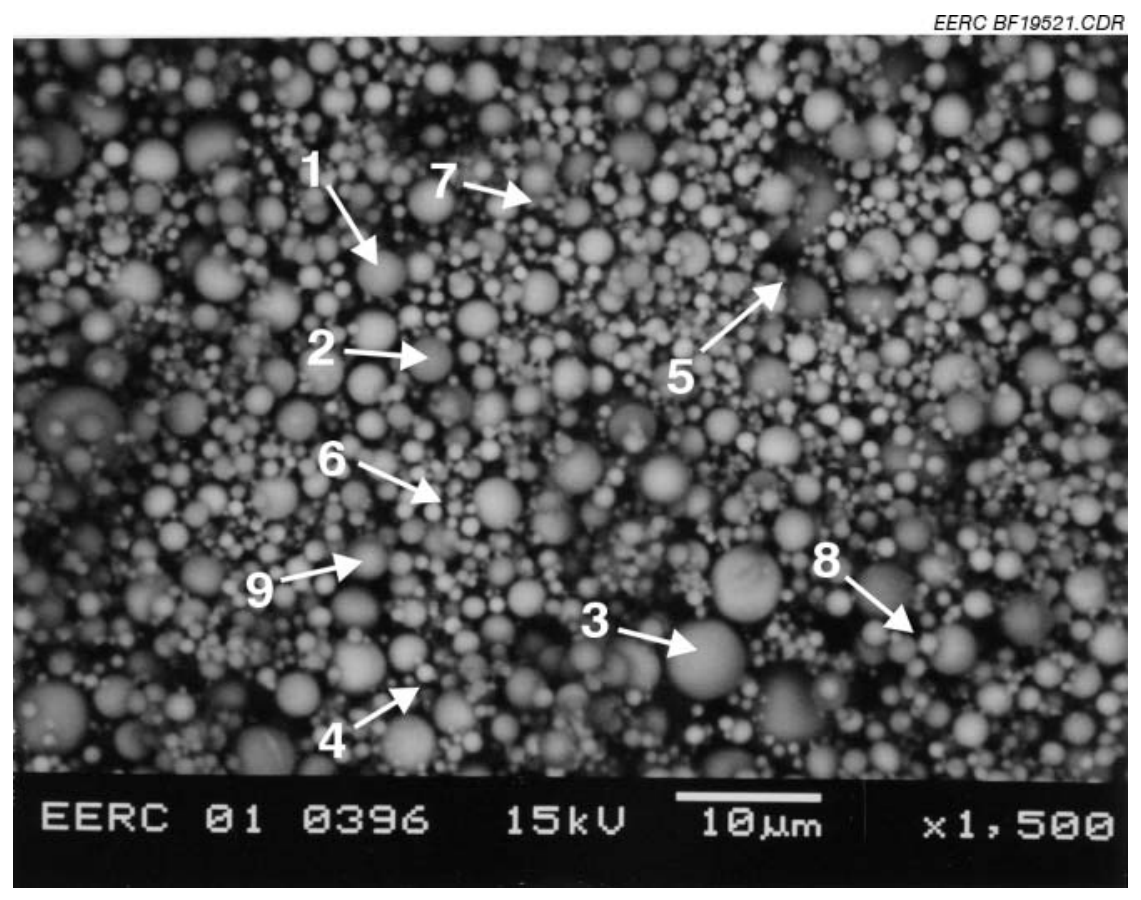

Figure 20b. SEM micrograph of 80-20 Cordero Rojo-sunflower hull fly ash. 


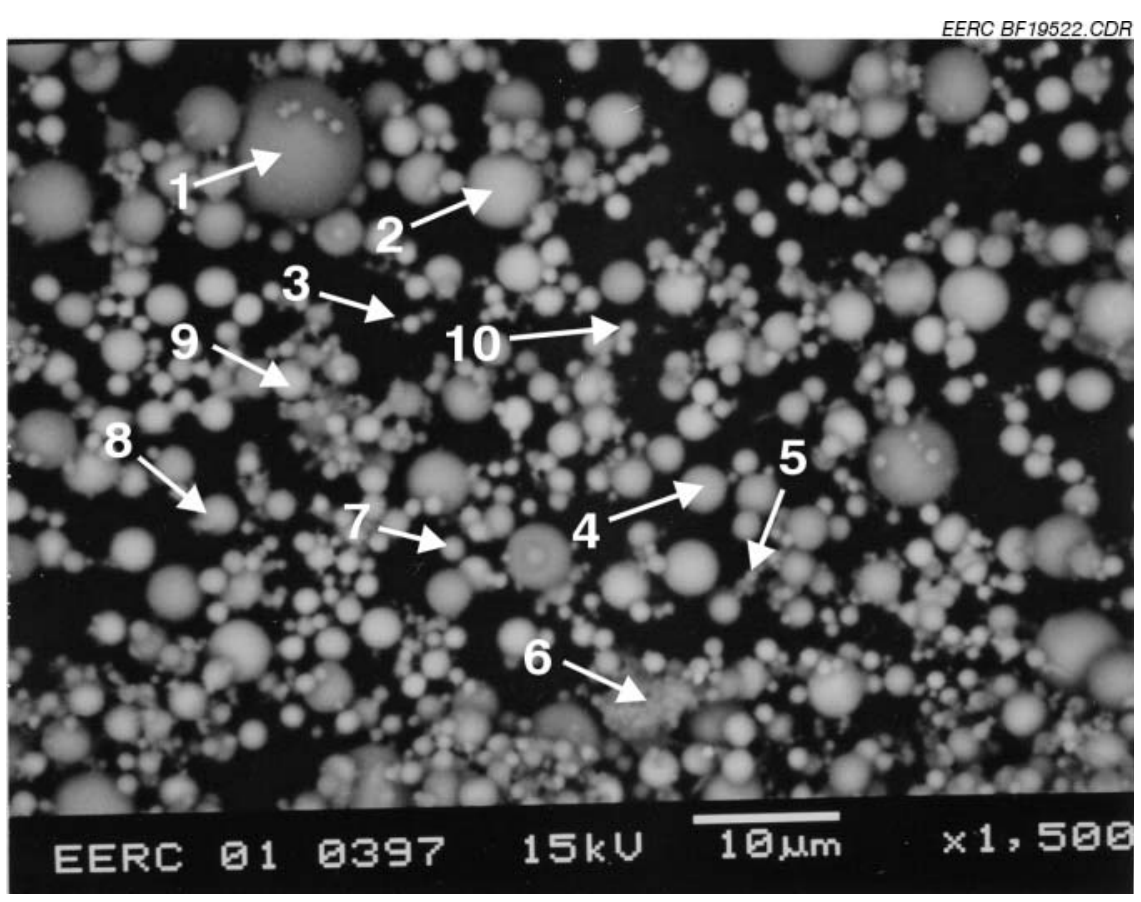

Figure 20c. SEM micrograph of 60-40 Cordero Rojo-sunflower hull fly ash.

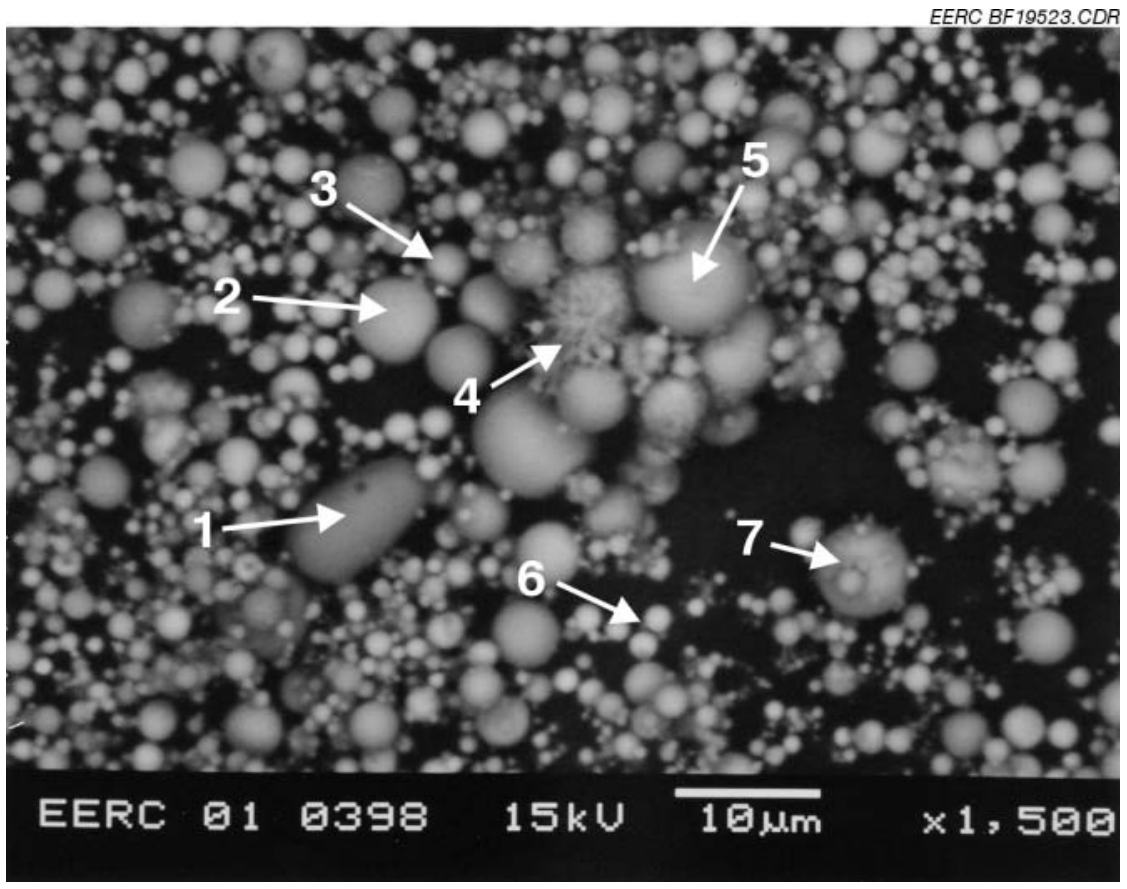

Figure 20d. SEM micrograph of 80-20 Cordero Rojo-wood chip fly ash. 


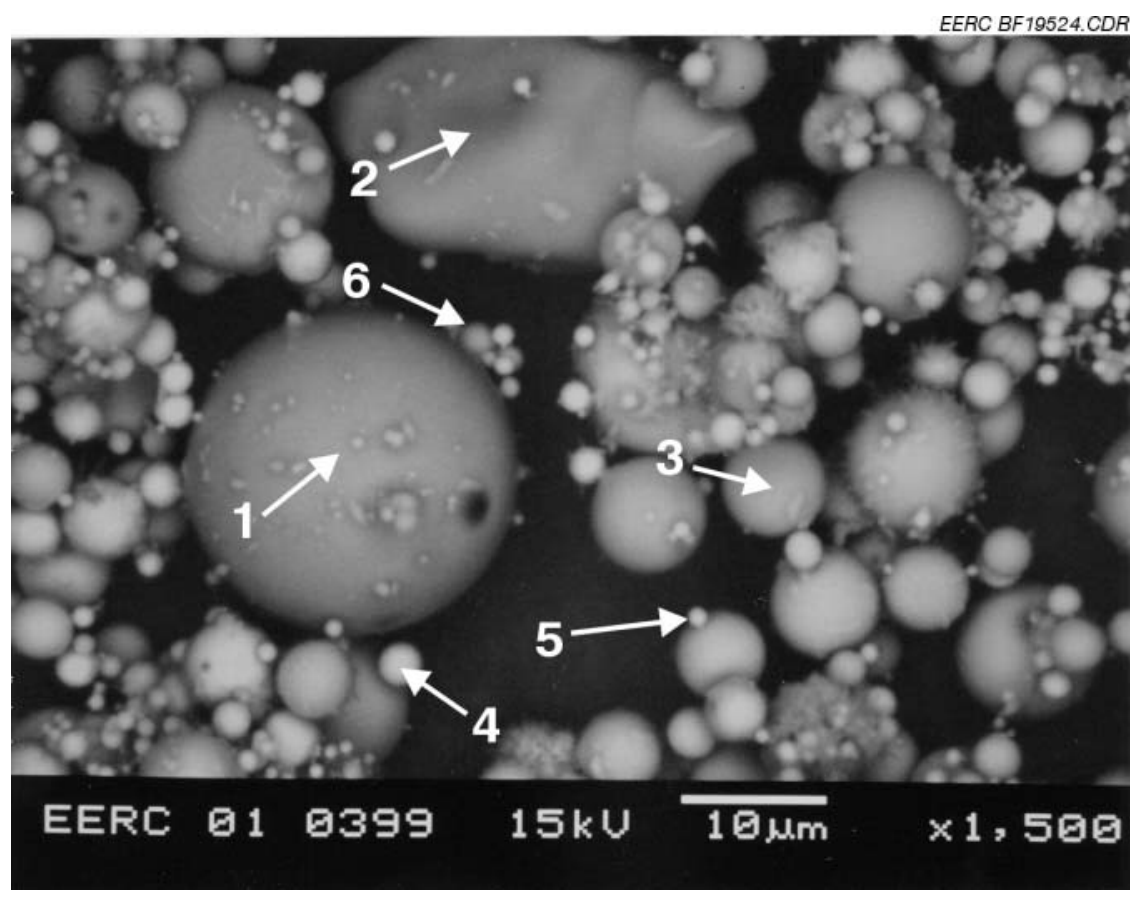

Figure 20e. SEM micrograph of 60-40 Cordero Rojo-wood chip fly ash.

Table 17a. 100\% Cordero Rojo Fly Ash Morphology Analysis Results, elemental wt\%

\begin{tabular}{lrrrrrrrrrr}
\hline Point: & 1 & \multicolumn{1}{c}{2} & \multicolumn{1}{c}{3} & \multicolumn{1}{c}{4} & \multicolumn{1}{c}{5} & \multicolumn{1}{c}{6} & \multicolumn{1}{c}{7} & \multicolumn{1}{c}{8} & \multicolumn{1}{c}{9} & \multicolumn{1}{c}{10} \\
\hline $\mathrm{Na}$ & 4.5 & 3.8 & 4.1 & 0.1 & 0.4 & 0.1 & 0.0 & 0.0 & 0.7 & 0.2 \\
$\mathrm{Mg}$ & 1.0 & 0.9 & 0.9 & 1.6 & 2.7 & 0.3 & 1.0 & 0.4 & 1.6 & 0.5 \\
$\mathrm{Al}$ & 20.0 & 16.7 & 23.2 & 5.0 & 12.5 & 1.2 & 8.4 & 2.4 & 7.0 & 2.0 \\
$\mathrm{Si}$ & 27.5 & 28.4 & 26.7 & 1.8 & 6.5 & 1.1 & 12.5 & 1.6 & 5.9 & 1.8 \\
$\mathrm{P}$ & 0.0 & 0.0 & 0.1 & 1.6 & 2.7 & 0.1 & 0.7 & 0.0 & 1.2 & 0.4 \\
$\mathrm{~S}$ & 0.1 & 0.1 & 0.2 & 0.7 & 1.5 & 21.3 & 1.5 & 5.8 & 13.3 & 20.6 \\
$\mathrm{Cl}$ & 0.1 & 0.2 & 0.1 & 0.1 & 0.3 & 0.2 & 0.0 & 0.4 & 0.5 & 0.3 \\
$\mathrm{~K}$ & 3.3 & 1.6 & 2.1 & 0.2 & 0.2 & 0.0 & 3.8 & 0.6 & 0.0 & 0.1 \\
$\mathrm{Ca}$ & 3.0 & 7.1 & 2.5 & 42.1 & 44.9 & 29.9 & 40.3 & 68.4 & 30.8 & 29.6 \\
$\mathrm{Ti}$ & 1.9 & 0.2 & 0.1 & 22.7 & 0.7 & 0.3 & 1.7 & 1.8 & 0.5 & 0.0 \\
$\mathrm{Cr}$ & 0.1 & 0.0 & 0.5 & 0.5 & 0.3 & 0.0 & 1.9 & 0.0 & 0.1 & 0.0 \\
$\mathrm{Fe}$ & 3.7 & 2.3 & 4.0 & 9.1 & 9.8 & 0.4 & 14.9 & 12.1 & 3.7 & 1.8 \\
$\mathrm{Ba}$ & 1.0 & 0.2 & 0.0 & 0.0 & 2.2 & 0.0 & 4.4 & 0.0 & 0.2 & 1.0 \\
$\mathrm{O}^{\mathrm{a}}$ & 33.8 & 38.6 & 35.5 & 14.5 & 15.4 & 45.1 & 9.0 & 6.5 & 34.7 & 41.8 \\
Total & 100.0 & 100.0 & 100.0 & 100.0 & 100.0 & 100.0 & 100.0 & 100.0 & 100.0 & 100 \\
\hline
\end{tabular}

${ }^{a}$ Determined by difference. 
Table 17b. 80-20 Cordero Rojo-Sunflower Hull Fly Ash Morphology Analysis

Results, elemental wt\%

\begin{tabular}{|c|c|c|c|c|c|c|c|c|c|c|}
\hline Point: & 1 & 2 & 3 & 4 & 5 & 6 & 7 & 8 & 9 & 0.4167 \\
\hline $\mathrm{Na}$ & 0.2 & 1.4 & 0.8 & 0.4 & 0.4 & 0.3 & 0.7 & 0.5 & 0.0 & 0.1 \\
\hline $\mathrm{Mg}$ & 3.1 & 2.0 & 1.6 & 2.9 & 1.5 & 2.9 & 2.8 & 2.8 & 3.9 & 16.2 \\
\hline $\mathrm{Al}$ & 15.3 & 2.6 & 3.8 & 11.6 & 3.1 & 10.5 & 9.6 & 13.0 & 4.4 & 11.8 \\
\hline $\mathrm{Si}$ & 4.7 & 38.6 & 29.2 & 6.4 & 36.7 & 7.2 & 14.2 & 4.9 & 13.8 & 17.8 \\
\hline $\mathrm{P}$ & 2.3 & 0.3 & 0.1 & 3.2 & 0.7 & 4.1 & 2.1 & 2.9 & 2.8 & 0.5 \\
\hline S & 0.5 & 0.5 & 0.1 & 1.2 & 0.7 & 1.5 & 2.4 & 1.2 & 0.5 & 0.8 \\
\hline $\mathrm{Cl}$ & 0.0 & 0.2 & 0.0 & 0.2 & 0.0 & 0.2 & 0.0 & 0.1 & 0.1 & 0.5 \\
\hline $\mathrm{K}$ & 0.3 & 8.1 & 6.4 & 1.2 & 7.5 & 1.5 & 5.6 & 1.5 & 0.6 & 1.0 \\
\hline $\mathrm{Ca}$ & 42.8 & 7.6 & 14.5 & 33.6 & 12.1 & 38.1 & 40.8 & 42.2 & 40.3 & 15.5 \\
\hline $\mathrm{Ti}$ & 0.4 & 0.3 & 11.0 & 2.4 & 0.3 & 0.6 & 0.4 & 1.5 & 0.2 & 0.4 \\
\hline $\mathrm{Cr}$ & 0.1 & 0.2 & 0.0 & 0.0 & 0.0 & 0.1 & 0.0 & 0.4 & 0.1 & 0.1 \\
\hline $\mathrm{Fe}$ & 8.8 & 5.0 & 5.0 & 6.7 & 5.7 & 8.8 & 8.0 & 9.5 & 5.6 & 3.9 \\
\hline $\mathrm{Ba}$ & 0.3 & 0.4 & 0.7 & 1.3 & 0.8 & 0.7 & 3.9 & 1.0 & 1.9 & 1.5 \\
\hline $\mathrm{O}^{\mathrm{b}}$ & 21.2 & 32.8 & 26.9 & 29.2 & 30.5 & 23.5 & 9.8 & 18.5 & 25.8 & 29.9 \\
\hline Total & 100.0 & 100.0 & 100.0 & 100.0 & 100.0 & 100.0 & 100.0 & 100.0 & 100.0 & 99.9 \\
\hline
\end{tabular}

${ }^{a}$ Not shown in picture.

${ }^{\mathrm{b}}$ Determined by difference.

Table 17c. 60-40 Cordero Rojo-Sunflower Hull Fly Ash Morphology Analysis Results, elemental wt\%

\begin{tabular}{lrrrrrrrrrr}
\hline Point: & \multicolumn{1}{c}{1} & \multicolumn{1}{c}{2} & \multicolumn{1}{c}{3} & \multicolumn{1}{c}{4} & \multicolumn{1}{c}{5} & \multicolumn{1}{c}{6} & \multicolumn{1}{c}{7} & \multicolumn{1}{c}{8} & \multicolumn{1}{c}{9} & \multicolumn{1}{c}{10} \\
\hline $\mathrm{Na}$ & 1.4 & 0.2 & 0.7 & 1.3 & 0.2 & 0.2 & 0.7 & 0.7 & 0.4 & 0.1 \\
$\mathrm{Mg}$ & 0.4 & 3.9 & 3.0 & 1.0 & 2.0 & 27.1 & 1.8 & 2.2 & 2.5 & 4.6 \\
$\mathrm{Al}$ & 22.9 & 6.5 & 7.2 & 0.9 & 7.3 & 1.2 & 2.8 & 13.2 & 7.2 & 11.1 \\
$\mathrm{Si}$ & 24.6 & 19.9 & 7.6 & 36.4 & 9.3 & 1.1 & 30.3 & 19.6 & 4.7 & 10.9 \\
$\mathrm{P}$ & 0.0 & 0.0 & 4.7 & 0.1 & 2.0 & 3.2 & 1.0 & 0.1 & 2.5 & 1.0 \\
$\mathrm{~S}$ & 0.0 & 0.1 & 2.8 & 0.0 & 1.8 & 1.7 & 0.6 & 0.4 & 1.5 & 0.2 \\
$\mathrm{Cl}$ & 0.0 & 0.1 & 0.2 & 0.0 & 0.4 & 1.8 & 0.3 & 0.2 & 3.0 & 0.2 \\
$\mathrm{~K}$ & 25.4 & 1.6 & 2.8 & 17.0 & 12.9 & 1.8 & 23.0 & 11.0 & 3.8 & 1.9 \\
$\mathrm{Ca}$ & 1.9 & 30.1 & 29.4 & 4.0 & 30.7 & 20.1 & 11.8 & 20.1 & 41.1 & 31.9 \\
$\mathrm{Ti}$ & 0.0 & 4.5 & 1.5 & 0.0 & 2.9 & 0.0 & 0.2 & 0.9 & 1.1 & 1.4 \\
$\mathrm{Cr}$ & 0.0 & 0.0 & 0.0 & 0.0 & 0.2 & 0.2 & 0.0 & 0.2 & 0.0 & 0.1 \\
$\mathrm{Fe}$ & 1.4 & 4.3 & 5.3 & 4.3 & 8.8 & 5.5 & 11.7 & 3.3 & 8.7 & 6.7 \\
$\mathrm{Ba}$ & 0.1 & 1.5 & 0.2 & 0.1 & 2.4 & 0.1 & 0.8 & 1.3 & 0.1 & 0.8 \\
$\mathrm{O}^{\mathrm{a}}$ & 21.9 & 27.1 & 34.6 & \multicolumn{1}{c}{34.6} & 19.2 & 36.1 & 15.0 & 26.9 & 23.4 & 29.2 \\
Total & 100 & 100.0 & 100.0 & 100 & 100 & 100 & 100 & 100 & 100 & 100 \\
\hline
\end{tabular}

${ }^{\mathrm{a}}$ Determined by difference. 
Table 17d. 80-20 Cordero Rojo-Wood Chip Fly Ash Morphology Analysis Results, elemental wt\%

\begin{tabular}{|c|c|c|c|c|c|c|c|c|c|c|}
\hline Point: & 1 & 2 & 3 & 4 & 5 & 6 & 7 & 8 & 9 & 0.4167 \\
\hline $\mathrm{Na}$ & 1.2 & 0.2 & 0.0 & 0.5 & 0.5 & 0.1 & 0.2 & 0.3 & 0.5 & 1.4 \\
\hline $\mathrm{Mg}$ & 0.9 & 1.5 & 5.2 & 1.0 & 4.2 & 18.8 & 4.4 & 3.4 & 3.0 & 0.6 \\
\hline $\mathrm{Al}$ & 1.9 & 22.9 & 8.6 & 2.2 & 8.7 & 9.3 & 5.8 & 8.1 & 9.1 & 25.1 \\
\hline $\mathrm{Si}$ & 56.3 & 11.9 & 6.6 & 1.6 & 4.0 & 1.9 & 15.6 & 5.7 & 7.7 & 35.1 \\
\hline $\mathrm{P}$ & 0.0 & 0.1 & 0.9 & 0.2 & 0.8 & 1.8 & 0.6 & 2.0 & 2.6 & 0.2 \\
\hline $\mathrm{S}$ & 0.1 & 0.1 & 0.9 & 2.0 & 1.2 & 1.4 & 0.4 & 2.9 & 1.6 & 0.0 \\
\hline $\mathrm{Cl}$ & 0.0 & 0.0 & 0.3 & 1.7 & 0.3 & 0.0 & 0.3 & 0.4 & 0.2 & 0.0 \\
\hline $\mathrm{K}$ & 2.3 & 0.1 & 0.1 & 0.3 & 0.0 & 0.0 & 0.0 & 0.2 & 0.1 & 2.4 \\
\hline $\mathrm{Ca}$ & 3.1 & 29.3 & 41.9 & 51.0 & 40.9 & 29.8 & 40.7 & 42.7 & 36.8 & 2.1 \\
\hline $\mathrm{Ti}$ & 0.7 & 0.2 & 0.5 & 0.1 & 1.5 & 0.8 & 0.5 & 1.1 & 0.2 & 0.1 \\
\hline $\mathrm{Cr}$ & 0.0 & 0.1 & 0.0 & 0.4 & 0.0 & 0.0 & 0.0 & 0.0 & 0.1 & 0.0 \\
\hline $\mathrm{Fe}$ & 3.3 & 4.0 & 10.8 & 1.2 & 8.0 & 15.1 & 6.0 & 13.1 & 10.4 & 1.9 \\
\hline $\mathrm{Ba}$ & 0.6 & 4.8 & 0.4 & 0.5 & 0.2 & 1.1 & 1.0 & 0.0 & 0.0 & 0.0 \\
\hline $\mathrm{O}^{\mathrm{b}}$ & 29.7 & 24.8 & 23.9 & 37.3 & 29.7 & 20.1 & 24.6 & 20.2 & 27.8 & 31.2 \\
\hline Total & 100.0 & 100.0 & 100.0 & 100.0 & 100.0 & 100.0 & 100.0 & 100.0 & 100.0 & 100 \\
\hline
\end{tabular}

${ }^{a}$ Not shown in picture.

${ }^{\mathrm{b}}$ Determined by difference.

Table 17e. 60-40 Cordero Rojo-Wood Chip Fly Ash Morphology Analysis Results, elemental wt $\%$

\begin{tabular}{lrrrrrrrrrr}
\hline Point: & \multicolumn{1}{c}{1} & \multicolumn{1}{c}{2} & \multicolumn{1}{c}{3} & \multicolumn{1}{c}{4} & \multicolumn{1}{c}{5} & \multicolumn{1}{c}{6} & 0.2917 & 0.3333 & 0.375 & 0.41667 \\
\hline $\mathrm{Na}$ & 2.0 & 0.5 & 1.2 & 0.1 & 0.3 & 0.3 & 0.2 & 0.3 & 0.3 & 0.9 \\
$\mathrm{Mg}$ & 0.8 & 0.2 & 2.1 & 1.6 & 4.4 & 4.5 & 0.9 & 0.8 & 0.5 & 2.4 \\
$\mathrm{Al}$ & 16.9 & 0.1 & 9.5 & 6.8 & 11.3 & 15.3 & 3.3 & 3.6 & 3.6 & 14.5 \\
$\mathrm{Si}$ & 31.4 & 58.1 & 25.9 & 6.7 & 8.1 & 9.9 & 3.4 & 5.5 & 4.8 & 21.4 \\
$\mathrm{P}$ & 0.3 & 0.0 & 0.0 & 0.3 & 1.5 & 0.9 & 0.8 & 0.1 & 0.0 & 0.0 \\
$\mathrm{~S}$ & 0.0 & 0.0 & 0.0 & 0.2 & 0.8 & 0.6 & 2.2 & 1.3 & 1.3 & 0.2 \\
$\mathrm{Cl}$ & 0.0 & 0.2 & 0.0 & 0.1 & 0.3 & 0.3 & 1.4 & 0.5 & 0.4 & 0.0 \\
$\mathrm{~K}$ & 2.0 & 0.4 & 1.1 & 0.0 & 0.5 & 0.5 & 1.1 & 0.1 & 0.8 & 1.3 \\
$\mathrm{Ca}$ & 7.2 & 1.1 & 22.8 & 43.6 & 32.1 & 28.5 & 55.5 & 53.1 & 47.4 & 24.6 \\
$\mathrm{Ti}$ & 0.7 & 0.1 & 4.6 & 13.8 & 3.2 & 0.5 & 4.7 & 1.8 & 2.2 & 0.9 \\
$\mathrm{Cr}$ & 0.2 & 0.1 & 0.2 & 0.4 & 0.1 & 0.0 & 0.0 & 0.3 & 0.0 & 0.0 \\
$\mathrm{Fe}$ & 3.4 & 0.7 & 3.1 & 11.3 & 6.5 & 6.5 & 10.8 & 7.1 & 6.2 & 4.3 \\
$\mathrm{Ba}$ & 0.5 & 0.0 & 2.1 & 1.5 & 1.4 & 1.7 & 5.6 & 2.5 & 2.8 & 0.5 \\
$\mathrm{O}^{\mathrm{b}}$ & 34.6 & 38.6 & 27.5 & 13.7 & 29.6 & 30.4 & 10.2 & 23.1 & 29.8 & 29.1 \\
Total & 100.0 & 100.0 & 100.0 & 100.0 & 100.0 & 100.0 & 100.0 & 100.0 & 100.0 & 100.0 \\
\hline
\end{tabular}

${ }^{\mathrm{a}}$ Not shown in picture.

${ }^{\mathrm{b}}$ Determined by difference. 


\begin{tabular}{|c|c|c|c|c|c|c|c|}
\hline Index & $\begin{array}{c}\text { Cordero } \\
\text { Rojo }\end{array}$ & $\begin{array}{c}100 \% \\
\text { Sunflower } \\
\text { Hulls }\end{array}$ & $\begin{array}{l}100 \% \\
\text { Wood } \\
\text { Chips }\end{array}$ & $\begin{array}{c}80 \% \\
\text { Coal- } \\
20 \% \\
\text { Sunflower } \\
\text { Hulls } \\
\end{array}$ & $\begin{array}{c}60 \% \text { Coal- } \\
40 \% \\
\text { Sunflower } \\
\text { Hulls } \\
\end{array}$ & $\begin{array}{c}80 \% \\
\text { Coal- } \\
20 \% \\
\text { Wood } \\
\text { Chips }\end{array}$ & $\begin{array}{c}60 \% \\
\text { Coal- } \\
40 \% \\
\text { Wood } \\
\text { Chips }\end{array}$ \\
\hline Grindability & 24 & 25 & 18 & 24 & 24 & 24 & 24 \\
\hline $\begin{array}{l}\text { Low-Temp. } \\
\text { Fouling }\end{array}$ & 8 & 22 & 6 & 9 & 11 & 8 & 7 \\
\hline $\begin{array}{l}\text { High-Temp. } \\
\text { Fouling }\end{array}$ & 32 & 34 & 47 & 40 & 45 & 33 & 34 \\
\hline Slagging & 39 & 33 & 20 & 66 & 82 & 40 & 40 \\
\hline Slag Tapping & N/A & N/A & N/A & N/A & N/A & N/A & N/A \\
\hline Sootblowing & 89 & 89 & 89 & 89 & 89 & 89 & 89 \\
\hline Tube Erosion & 70 & 5 & 5 & 53 & 34 & 67 & 62 \\
\hline Opacity & 50 & 69 & 15 & 56 & 61 & 49 & 48 \\
\hline
\end{tabular}

Note:

Sherco Unit 1 with baghouse selected used - boiler parameters off.

Biomass total excluded is set at $5 \%$.

$100 \%$ wood chips cause divide by zero error.

All 1-2.6- $\mu \mathrm{m}$ minerals set to 0.1 .

Table 19. Relative Severity of Fouling at Furnace Exit Temperature of $1500^{\circ} \mathrm{C}\left(2732^{\circ} \mathrm{F}\right)$

\begin{tabular}{lcccc}
\hline Coal-Biomass Ratio: & $100-0$ & $80-20$ & $60-40$ & $0-100$ \\
\hline Sunflower Hulls & & & & \\
Viscosity, $\log _{10}$ poise & 0.95 & 0.79 & 0.67 & 0.33 \\
\% in Liquid Phases & 90 & 89 & 83 & 42 \\
Deposition Rate, g/kg ash & 251 & 300 & 329 & 341 \\
\% Ash & 5 & 5 & 6 & 7 \\
Btu/kg Fuel & 19,496 & 19,036 & 18,575 & 17,193 \\
Deposition Rate, g/1000 Btu & 0.64 & 0.86 & 1.05 & 1.45 \\
& & & & \\
Wood Chips & 0.95 & 0.94 & 0.93 & 0.67 \\
Viscosity, log ${ }_{10}$ poise & 90 & 90 & 90 & 89 \\
\% in Liquid Phases & 251 & 253 & 256 & 353 \\
Deposition Rate, g/kg ash & 5 & 4 & 3 & 1 \\
\% Ash & 19,496 & 19,238 & 18,979 & 18,203 \\
Btu/kg Fuel & 0.64 & 0.54 & 0.43 & 0.12 \\
Deposition Rate, g/1000 Btu & & & & \\
\hline
\end{tabular}


lowest for wood chips. The fouling rate potential for the coal-biomass samples increases as the amount of sunflower hulls increase and decreases as the amount of wood chips increase.

\section{Task 5 - Pilot Scale Testing}

Three pilot-scale tests were completed using the retrofitted stoker-firing configuration on the EERC's CTF. These tests were completed after a number of shakedown tests were used to verify the operability of the newly installed firing system. As described previously, the equipment went through a series of changes to improve operability prior to firing the coal and coal-biomass blends. In the first test, AF-CTS-Stoker01, Cordero Rojo subbituminous coal was fired to establish the baseline for the test series. Subsequent tests fired Cordero Rojo coal blended with wood chips (AFCTS-Stoker02) and with sunflower hulls (AF-CTS-Stoker03). A discussion of test results follows.

\section{Fuel Preparation}

Cordero Rojo subbituminous coal was screened to achieve a fuel feed with a size distribution of $1.9 \times 0.6 \mathrm{~cm}(0.75 \times 0.25 \mathrm{in}$. $)$. The screened coal was transferred to a charge hopper for use in each of the pilot tests. Wood samples were also milled using a 1.9-cm (0.75-in.) screen; however, initial attempts to feed the wood indicated that the large size and varied distribution made feeding difficult. The wood was then milled a second time using a $1.3-\mathrm{cm}(0.5-\mathrm{in}$.) screen to reduce the size and create a more uniform distribution. Results were better, but required special attention to maintain fuel feed. No initial preparation of the sunflower hulls was required. The hulls were $0.6 \mathrm{~cm}$ ( 0.25 in.) top size with few smaller pieces. The sunflower hulls fed considerably better than the wood; however, attention was required to maintain a constant fuel feed.

\section{Fuel Analyses}

\section{Standard ASTM Analyses}

The proximate, ultimate, heating value, and bulk inorganic composition analyses for each of the test fuels are summarized in Table 20. The Cordero Rojo coal is typical of many PRB coals in its analysis. The sample fired here was drier (20 wt \% moisture) than the as-received fuel from the mine (typically $26 \mathrm{wt} \%$ ), which accounts for the higher-than-average heat content $(21,669 \mathrm{~kJ} / \mathrm{kg}$ [9325 Btu/lb]) for coals from the middle portion of the PRB (typically 19,520-19,985 $\mathrm{kJ} / \mathrm{kg}$ [8400-8600 Btu/lb]). Inorganics were present at the $5.14 \mathrm{wt} \%$ level and consisted primarily of silica (35.3 wt \%), alumina (21.1 wt\%), and calcium (27.7 wt\%) on a $\mathrm{SO}_{3}$-free basis. Sodium was present at the $1.02 \mathrm{wt} \%$ level. As described above, the fuel was double-screened to a size of $1.9 \times 0.6 \mathrm{~cm}$ $(0.75 \times 0.25 \mathrm{in}$. $)$, resulting in a fuel density of $726.2 \mathrm{~kg} / \mathrm{m}^{3}\left(45.3 \mathrm{lb} / \mathrm{ft}^{3}\right)$. Chloride content of the coal was measured at $21.3 \mu \mathrm{g} / \mathrm{g}$.

The as-fired wood chips were low in moisture $(5.2 \mathrm{wt} \%)$ and ash $(0.55 \mathrm{wt} \%)$ and contained a high-volatile-matter component $(78.54 \mathrm{wt} \%)$ relative to the coal $(37.61 \mathrm{wt} \%)$. Because of the low moisture content, the as-fired wood chips had a fairly high heating value of $18,042 \mathrm{~kJ} / \mathrm{kg}$ $(7764 \mathrm{Btu} / \mathrm{lb})$. The wood was milled to a size of $1.3 \mathrm{~cm} \times 0(0.5 \mathrm{in} . \times 0)$ and had a density of $222.8 \mathrm{~kg} / \mathrm{m}^{3}\left(13.9 \mathrm{lb} / \mathrm{ft}^{3}\right)$. The low ash content was dominated by calcium $(34.2 \mathrm{wt} \%)$ and potassium 
Table 20. Fuel Analyses

\begin{tabular}{|c|c|c|c|c|c|c|}
\hline \multirow[t]{2}{*}{$\begin{array}{l}\text { Fuel Description: } \\
\text { Sample Number: }\end{array}$} & \multicolumn{2}{|c|}{$\begin{array}{c}\text { Cordero Rojo Coal } \\
02-0106 \\
\end{array}$} & \multicolumn{2}{|c|}{$\begin{array}{c}\text { Wood Chips } \\
02-0119 \\
\end{array}$} & \multicolumn{2}{|c|}{$\begin{array}{c}\text { Sunflower Hulls } \\
02-0123\end{array}$} \\
\hline & As-Fired & $\mathrm{H}_{2} \mathrm{O}$-Free & As-Fired & $\mathrm{H}_{2} \mathrm{O}$-Free & As-Fired & $\mathrm{H}_{2} \mathrm{O}$-Free \\
\hline \multicolumn{7}{|l|}{ Proximate Analysis, wt\% } \\
\hline Moisture & 20 & - & 5.2 & - & 11.4 & - \\
\hline Volatile Matter & 37.61 & 47 & 78.54 & 82.84 & 72.21 & 81.46 \\
\hline Fixed Carbon & 37.25 & 46.58 & 15.71 & 16.58 & 13.53 & 15.32 \\
\hline Ash & 5.14 & 6.42 & 0.55 & 0.58 & 2.85 & 3.22 \\
\hline \multicolumn{7}{|l|}{ Ultimate Analysis, wt $\%$} \\
\hline Hydrogen & 5.87 & 4.56 & 6.28 & 6.02 & 7 & 6.47 \\
\hline Carbon & 53.37 & 66.7 & 46.46 & 49 & 46.35 & 52.28 \\
\hline Nitrogen & 0.67 & 0.84 & 0.01 & 0.01 & 1.39 & 1.57 \\
\hline Sulfur & 0.23 & 0.29 & 0.36 & 0.38 & 0.52 & 0.59 \\
\hline Oxygen & 34.72 & 21.19 & 46.34 & 44.01 & 41.89 & 35.87 \\
\hline Ash & 5.14 & 6.42 & 0.55 & 0.58 & 2.85 & 3.22 \\
\hline Heating Value, Btu/lb & 9325 & 11,653 & 7764 & 8189 & 7754 & 8747 \\
\hline Chloride, $\mu \mathrm{g} / \mathrm{g}$ & \multicolumn{2}{|c|}{21.3} & \multicolumn{2}{|c|}{71.9} & \multicolumn{2}{|c|}{601} \\
\hline Fuel Size & \multirow{2}{*}{\multicolumn{2}{|c|}{$\begin{array}{c}3 / 4 " \times 1 / 4 " \\
45.3\end{array}$}} & \multirow{2}{*}{\multicolumn{2}{|c|}{$\begin{array}{c}1 / 2 " \times 0 \\
13.9\end{array}$}} & \multirow{2}{*}{\multicolumn{2}{|c|}{$\begin{array}{c}1 / 4 " \times 0 \\
8.21\end{array}$}} \\
\hline Fuel Density, lb/ft $\mathrm{ft}^{3}$ & & & & & & \\
\hline Ash Analysis, wt $\%$ & As-Fired & $\mathrm{SO}_{3}$-Free & As-Fired & $\mathrm{SO}_{3}$-Free & As-Fired & $\mathrm{SO}_{3}$-Free \\
\hline $\mathrm{SiO}_{2}$ & 31.2 & 35.3 & 7.52 & 7.71 & 2.95 & 3.15 \\
\hline $\mathrm{Al}_{2} \mathrm{O}_{3}$ & 18.6 & 21.1 & 1.75 & 1.79 & 0.83 & 0.88 \\
\hline $\mathrm{Fe}_{2} \mathrm{O}_{3}$ & 4.57 & 5.18 & 8.76 & 8.98 & 0.71 & 0.76 \\
\hline $\mathrm{TiO}_{2}$ & 1.65 & 1.87 & 0.41 & 0.42 & 0.06 & 0.07 \\
\hline $\mathrm{P}_{2} \mathrm{O}_{5}$ & 1.24 & 1.4 & 2.39 & 2.45 & 14.2 & 15.2 \\
\hline $\mathrm{CaO}$ & 24.5 & 27.7 & 33.4 & 34.2 & 13.6 & 14.5 \\
\hline $\mathrm{MgO}$ & 5.28 & 5.98 & 5.48 & 5.61 & 14 & 14.9 \\
\hline $\mathrm{Na}_{2} \mathrm{O}$ & 0.9 & 1.02 & 0.88 & 0.9 & 0.05 & 0.05 \\
\hline $\mathrm{K}_{2} \mathrm{O}$ & 0.42 & 0.48 & 37 & 37.9 & 47.2 & 50.5 \\
\hline $\mathrm{SO}_{3}$ & 11.7 & - & 2.42 & - & 6.38 & - \\
\hline
\end{tabular}

( $37.9 \mathrm{wt} \%$ ), with silica, iron, and magnesium making up approximately $22.25 \mathrm{wt} \%$ of the remaining ash-forming materials, reported on an $\mathrm{SO}_{3}$-free basis. Chloride content was measured at $71.9 \mu \mathrm{g} / \mathrm{g}$.

Sunflower hulls were fired as received with no additional preparation. They contained a moderate level of moisture at $11.4 \mathrm{wt} \%$ and a fairly low ash content of $2.85 \mathrm{wt} \%$. Heating value was similar to the wood chips at $18,019 \mathrm{~kJ} / \mathrm{kg}(7754 \mathrm{Btu} / \mathrm{lb})$, while the bulk density of $131.6 \mathrm{~kg} / \mathrm{m}^{3}$ $\left(8.21 \mathrm{lb} / \mathrm{ft}^{3}\right)$ was the lowest of all fuels fired. The sunflower hulls were similar in volatile matter content to that of the wood chips at $72.21 \mathrm{wt} \%$. The inorganic portion of the hulls comprised mainly alkali and alkaline-earth elements: $50.5 \mathrm{wt} \%$ potassium, $14.9 \mathrm{wt} \%$ magnesium, and $14.5 \mathrm{wt} \%$ calcium on a $\mathrm{SO}_{3}$-free basis. Phosphorus content was very high relative to most other fuels at 15.2 $\mathrm{wt} \%$. Chloride content was measured at $601 \mu \mathrm{g} / \mathrm{g}$.

In general, all of the fuels can be expected to burn well in a stoker-fired arrangement. They are all highly reactive, with fixed carbon-to-volatile matter ratios of less than 1.0. The greatest potential problem is that there is a very high alkaline content in the biomass fuels, with potassium 
and calcium making up more than $60 \%$ of all ash-forming materials. In addition to the high alkali content of the coal, the potential for clinker formation is substantial. The high alkaline content of the fuels also indicates a potential for problematic ash deposition, which will be highly dependent upon the firing temperature. Fortunately, stoker-fired systems are generally operated to achieve furnace exit gas temperatures (FEGTs) at or below $1094^{\circ} \mathrm{C}\left(2000^{\circ} \mathrm{F}\right)$.

\section{Advanced Fuel Analyses}

Each of the fuels was also analyzed by CHF and CCSEM. Results of these analyses are provided in Tables 21 and 22. CHF analyses indicate that nearly all of the alkaline materials in each fuel are organically associated. As such, they will most likely be available as gas-phase components, acting upon the surfaces of fly ash grains as they cool through the combustion system to create lower-melting-point liquid phases. In fact, only a small portion of all ash-forming materials in each biomass fuel is not organically associated. A portion of the calcium (about $40 \mathrm{wt} \%$ ) and potassium $(65 \mathrm{wt} \%)$ in the Cordero Rojo coal is tied up with clay materials.

CCSEM analyses indicate quartz (24.8 wt $\%$ ), kaolinite (18.9 wt $\%$ ), and montmorillonite $(16.1 \mathrm{wt} \%)$ as the major mineral phases present in the Cordero Rojo coal. Nearly $50 \mathrm{wt} \%$ of these phases are excluded from the coal matrix. The coal contains minor amounts (less than $5 \mathrm{wt} \%$ ) of dolomite, calcium aluminosilicate, sodium aluminosilicate, calcium aluminophosphate, and silicarich mineral phases. Unclassified phases totaled $11.3 \mathrm{wt} \%$. More than $50 \mathrm{wt} \%$ of all phases identified were less than $10 \mu \mathrm{m}$ in size. The major mineral phases present in the wood sample were gypsum at $35.0 \mathrm{wt} \%$ and a mixed aluminosilicate at $6.2 \mathrm{wt} \%$. Minor amounts of quartz, iron oxide, potassium aluminosilicate, oxidized pyrrhotite, and silica-rich phases were present in the wood. Unclassified phases totaled $42.9 \mathrm{wt} \%$. These phases did not conform to normal mineral associations and were most likely present as an amorphous mixture of elements. The wood minerals were primarily greater than $10 \mu \mathrm{m}$ in size $(73 \mathrm{wt} \%)$. No major minerals were identified in the sunflower sample analyzed. A minor amount of iron oxide was present at $2.3 \mathrm{wt} \%$ of the sample. Remaining phases were unclassified, with $43 \mathrm{wt} \%$ less than $10 \mu \mathrm{m}$ in size.

\section{Operating Parameters}

The goal of each test was to fire the coal and coal-biomass blends at a rate to achieve a FEGT of $1038^{\circ} \mathrm{C}\left(1900^{\circ} \mathrm{F}\right)$ with excess air controlled to between $35 \%$ and $40 \%$. Table 23 provides a summary of run averages of the major operating parameters for each test. During the baseline test, coal was fired at about $39.5 \mathrm{~kg} / \mathrm{hr}(87 \mathrm{lb} / \mathrm{hr})$ achieving a FEGT of $1065^{\circ} \mathrm{C}\left(1948^{\circ} \mathrm{F}\right)$ at an excess air level of $33 \%$. Sulfur dioxide concentrations averaged $257 \mathrm{ppm}$ (dry volume basis), $\mathrm{NO}_{\mathrm{x}}$ concentrations were $167 \mathrm{ppm}$, and carbon monoxide levels averaged $41 \mathrm{ppm}$. Higher feed rates ( $>41 \mathrm{~kg} / \mathrm{hr}$, or $>90 \mathrm{lb} / \mathrm{hr}$ ) and excess air levels (near $40 \%$ ) were required for each of the biomass blend tests. Because of the lower sulfur content of the biomass fuels, the overall sulfur dioxide emission rates were reduced from $0.15 \mathrm{~kg}$ of $\mathrm{SO}_{2} / \mathrm{hr}$ to 0.10 and $0.08 \mathrm{~kg}_{\text {of SO}} / \mathrm{hr}(0.33 \mathrm{lb}$ of SO$/ 2 / \mathrm{hr}$ to 0.22 and $0.17 \mathrm{lb}$ of $\mathrm{SO}_{2} / \mathrm{hr}$ ), respectively, for the wood chip and sunflower hull blends. Because of the higher ash and alkali content of the sunflower hulls, a greater proportion of the sulfur was captured by the fly ash. 
Table 21. CHF Results

\begin{tabular}{|c|c|c|c|c|}
\hline & \multicolumn{4}{|c|}{ Cordero Rojo Coal } \\
\hline & $\mathrm{wt} \%$ by $\mathrm{H}_{2} \mathrm{O}$ & $\mathrm{wt} \%$ by $\mathrm{NH}_{4} \mathrm{OAc}$ & $\mathrm{wt} \%$ by $\mathrm{HCl}$ & $\mathrm{wt} \%$ Remaining \\
\hline Silicon & 0 & 0 & 0 & 100 \\
\hline Aluminum & 0 & 0 & 28 & 72 \\
\hline Iron & 4 & 1 & 78 & 17 \\
\hline Titanium & 0 & 0 & 0 & 100 \\
\hline Phosphorus & 5 & 0 & 88 & 7 \\
\hline Calcium & 2 & 56 & 39 & 2 \\
\hline Magnesium & 1 & 78 & 17 & 5 \\
\hline Sodium & 32 & 68 & 0 & 0 \\
\hline Potassium & 0 & 35 & 0 & 65 \\
\hline \multirow[t]{3}{*}{ Sulfur } & 6 & 15 & 75 & 3 \\
\hline & \multicolumn{4}{|c|}{ Wood Chips } \\
\hline & $\mathrm{wt} \%$ by $\mathrm{H}_{2} \mathrm{O}$ & $\mathrm{wt} \%$ by $\mathrm{NH}_{4} \mathrm{OAc}$ & $\mathrm{wt} \%$ by $\mathrm{HCl}$ & $\mathrm{wt} \%$ Remaining \\
\hline Silicon & 69 & 8 & 9 & 14 \\
\hline Aluminum & 68 & 0 & 0 & 34 \\
\hline Iron & 63 & 9 & 25 & 3 \\
\hline Titanium & 66 & 7 & 12 & 14 \\
\hline Phosphorus & 82 & 5 & 9 & 4 \\
\hline Calcium & 68 & 26 & 5 & 1 \\
\hline Magnesium & 75 & 21 & 2 & 1 \\
\hline Sodium & 86 & 0 & 9 & 5 \\
\hline Potassium & 87 & 8 & 4 & 2 \\
\hline \multirow[t]{3}{*}{ Sulfur } & 67 & 21 & 8 & 4 \\
\hline & \multicolumn{4}{|c|}{ Sunflower Hulls } \\
\hline & $\mathrm{wt} \%$ by $\mathrm{H}_{2} \mathrm{O}$ & $\mathrm{wt} \%$ by $\mathrm{NH}_{4} \mathrm{OAc}$ & $\mathrm{wt} \%$ by $\mathrm{HCl}$ & wt $\%$ Remaining \\
\hline Silicon & 41 & 32 & 23 & 4 \\
\hline Aluminum & 49 & 26 & 22 & 3 \\
\hline Iron & 2 & 11 & 85 & 2 \\
\hline Titanium & 47 & 32 & 19 & 3 \\
\hline Phosphorus & 65 & 28 & 7 & 0 \\
\hline Calcium & 35 & 41 & 24 & 0 \\
\hline Magnesium & 46 & 49 & 5 & 0 \\
\hline Sodium & 100 & 0 & 0 & 0 \\
\hline Potassium & 60 & 39 & 1 & 0 \\
\hline Sulfur & 32 & 33 & 34 & 0 \\
\hline
\end{tabular}


Table 22. CCSEM Results - Cordero Rojo Coal

\begin{tabular}{|c|c|c|c|c|c|c|c|c|}
\hline Classification: & $1.0-2.2$ & $2.2-4.6$ & $4.6-10$ & $10-22$ & $22-46$ & $46-100$ & Totals & $\begin{array}{c}\text { wt } \% \\
\text { Excluded }\end{array}$ \\
\hline Quartz & 1.9 & 3.4 & 5.7 & 7.2 & 4.7 & 1.9 & 24.8 & 54.0 \\
\hline Iron Oxide & 0.2 & 0.0 & 0.1 & 0.0 & 0.0 & 0.0 & 0.2 & 73.6 \\
\hline Periclase & 0.0 & 0 & 0.0 & 0.0 & 0.0 & 0.0 & 0.0 & 0.0 \\
\hline Rutile & 0.2 & 0.5 & 0.2 & 0.6 & 0.0 & 0.0 & 1.5 & 51.4 \\
\hline Alumina & 0.0 & 0 & 0.0 & 0.5 & 0.0 & 0.0 & 0.5 & 100.0 \\
\hline Calcite & 0.0 & 0 & 0.1 & 0.0 & 0.0 & 0.0 & 0.1 & 23.1 \\
\hline Dolomite & 0.1 & 0.4 & 0.2 & 0.9 & 0.4 & 0.3 & 2.4 & 82.5 \\
\hline Ankerite & 0.0 & 0.0 & 0 & 0 & 0.0 & 0.0 & 0.0 & 0.0 \\
\hline Kaolinite & 2.2 & 2.7 & 4.8 & 5.8 & 2.1 & 1.3 & 18.9 & 43.7 \\
\hline Montmorillonite & 1.3 & 4.0 & 3.3 & 3.8 & 2.0 & 1.6 & 16.1 & 25.0 \\
\hline K Al-Silicate & 0.2 & 0.8 & 0.4 & 0.2 & 0.1 & 0.0 & 1.7 & 30.4 \\
\hline Fe Al-Silicate & 0.1 & 0.3 & 0.4 & 0.4 & 0.3 & 1.8 & 3.2 & 62.1 \\
\hline Ca Al-Silicate & 0.5 & 0.5 & 0.8 & 1.2 & 0.3 & 0.3 & 3.6 & 27.3 \\
\hline Na Al-Silicate & 0.0 & 0.0 & 0.0 & 0.0 & 0.0 & 0.0 & 0 & 0 \\
\hline Aluminosilicate & 0.1 & 0.3 & 0.5 & 1.4 & 0.5 & 0.2 & 2.9 & 56.7 \\
\hline Mixed Al-Si & 0.3 & 0.3 & 0.3 & 0.1 & 0.1 & 0.0 & 1.0 & 16.8 \\
\hline Fe Silicate & 0.0 & 0.1 & 0.0 & 0.0 & 0.0 & 0.0 & 0.1 & 80.4 \\
\hline Ca Silicate & 0.0 & 0.0 & 0.1 & 0.3 & 0.0 & 0.0 & 0.4 & 90.2 \\
\hline Ca Aluminate & 0.0 & 0.0 & 0.0 & 0.0 & 0.0 & 0.0 & 0.0 & 0 \\
\hline Pyrite & 0.0 & 0.0 & 0.0 & 0.0 & 0.0 & 0.0 & 0.0 & 0 \\
\hline Pyrrhotite & 0.2 & 0.4 & 0.4 & 0.2 & 0.2 & 0.0 & 1.4 & 59 \\
\hline Oxidized & 0.0 & 0.1 & 0.0 & 0.0 & 0.0 & 0.0 & 0.2 & 69.5 \\
\hline \multicolumn{9}{|l|}{ Pyrrhotite } \\
\hline Gypsum & 0.0 & 0.0 & 0.0 & 0.2 & 0.0 & 0.0 & 0.3 & 100 \\
\hline Barite & 0.1 & 0.0 & 0.2 & 0.4 & 0.0 & 0.0 & 0.6 & 84.5 \\
\hline Apatite & 0.0 & 0.0 & 0.0 & 0.0 & 0.0 & 0.0 & 0.0 & 0 \\
\hline Ca Al-Phosphate & 0.8 & 1.2 & 1.4 & 0.7 & 0.1 & 0.0 & 4.1 & 8.2 \\
\hline $\mathrm{KCl}$ & 0.0 & 0.0 & 0.0 & 0.0 & 0.0 & 0.0 & 0.0 & 0 \\
\hline Gypsum/Barite & 0.0 & 0.0 & 0.0 & 0.0 & 0.0 & 0.0 & 0.0 & 0 \\
\hline Gypsum/Al-Si & 0.5 & 0.7 & 0.2 & 0.0 & 0.1 & 0.0 & 1.5 & 16.2 \\
\hline Si-Rich & 0.4 & 0.7 & 0.3 & 0.9 & 0.3 & 0.5 & 3.1 & 45.6 \\
\hline Ca-Rich & 0.0 & 0.0 & 0.0 & 0.0 & 0.0 & 0.0 & 0.0 & 0 \\
\hline $\mathrm{Ca}-\mathrm{Si}$-Rich & 0.0 & 0.0 & 0.0 & 0.0 & 0.0 & 0.0 & 0.0 & 0.0 \\
\hline Unclassified & 1.8 & 3.0 & 2.4 & 1.4 & 0.4 & 2.3 & 11.3 & 28.6 \\
\hline Totals & 11.1 & 19.4 & 21.9 & 26.1 & 11.6 & 10.0 & 100.0 & \\
\hline
\end{tabular}

Continued. . . 
Table 22. (continued) - Wood Chips

\begin{tabular}{|c|c|c|c|c|c|c|c|c|}
\hline Classification: & $1.0-2.2$ & $2.2-4.6$ & $4.6-10$ & $10-22$ & $22-46$ & $46-100$ & Totals & $\begin{array}{c}\mathrm{wt} \% \\
\text { Excluded }\end{array}$ \\
\hline Quartz & 0.1 & 0.3 & 0.5 & 0.3 & 0.3 & 0.1 & 1.6 & \\
\hline Iron Oxide & 0.2 & 0.6 & 0.6 & 0.4 & 0.6 & 0.1 & 2.4 & \\
\hline Periclase & 0.0 & 0.0 & 0.0 & 0.0 & 0.0 & 0.0 & 0.0 & \\
\hline Rutile & 0.0 & 0.0 & 0.0 & 0.0 & 0.0 & 0.0 & 0.0 & \\
\hline Alumina & 0.0 & 0.1 & 0.0 & 0.0 & 0.0 & 0.0 & 0.1 & \\
\hline Calcite & 0.0 & 0.1 & 0.1 & 0.0 & 0.0 & 0.0 & 0.2 & \\
\hline Dolomite & 0.0 & 0.0 & 0.0 & 0.0 & 0.0 & 0.0 & 0.0 & \\
\hline Ankerite & 0.0 & 0.0 & 0.0 & 0.0 & 0.0 & 0.0 & 0.0 & \\
\hline Kaolinite & 0.0 & 0.1 & 0.2 & 0.3 & 0.1 & 0.1 & 0.8 & \\
\hline Montmorillonite & 0.0 & 0.0 & 0.0 & 0.0 & 0.1 & 0.0 & 0.1 & \\
\hline K Al-Silicate & 0.3 & 0.8 & 1.0 & 0.7 & 0.5 & 0.7 & 4.0 & \\
\hline Fe Al-Silicate & 0.1 & 0.1 & 0.6 & 0.1 & 0.3 & 0.3 & 1.5 & \\
\hline Ca Al-Silicate & 0.0 & 0.1 & 0.1 & 0.2 & 0.2 & 0.1 & 0.7 & \\
\hline Na Al-Silicate & 0.0 & 0.1 & 0.1 & 0.0 & 0.1 & 0.0 & 0.2 & \\
\hline Aluminosilicate & 0.0 & 0.0 & 0.0 & 0.0 & 0.0 & 0.0 & 0.0 & \\
\hline Mixed Al-Si & 0.2 & 0.9 & 1.3 & 1.6 & 1.0 & 1.1 & 6.2 & \\
\hline Fe Silicate & 0.0 & 0.0 & 0.0 & 0.0 & 0.0 & 0.0 & 0.0 & \\
\hline Ca Silicate & 0.0 & 0.0 & 0.0 & 0.2 & 0.0 & 0.0 & 0.3 & \\
\hline $\mathrm{Ca}$ Aluminate & 0.0 & 0.0 & 0.0 & 0.0 & 0.0 & 0.0 & 0.0 & \\
\hline Pyrite & 0.0 & 0.0 & 0.0 & 0.0 & 0.0 & 0.0 & 0.0 & \\
\hline Pyrrhotite & 0.0 & 0.0 & 0.0 & 0.0 & 0.0 & 0.0 & 0.0 & \\
\hline Oxidized & 0.1 & 0.1 & 0.1 & 0.7 & 0.1 & 0.7 & 1.7 & \\
\hline \multicolumn{9}{|l|}{ Pyrrhotite } \\
\hline Gypsum & 0.2 & 0.2 & 0.1 & 0.2 & 0.2 & 0.0 & 1.0 & \\
\hline Barite & 0.0 & 0.0 & 0.0 & 0.0 & 0.0 & 0.0 & 0.0 & \\
\hline Apatite & 0.0 & 0.0 & 0.0 & 0.0 & 0.0 & 0.0 & 0.0 & \\
\hline Ca Al-Phosphate & 0.0 & 0.0 & 0.0 & 0.0 & 0.0 & 0.0 & 0.0 & \\
\hline $\mathrm{KCl}$ & 0.0 & 0.0 & 0.0 & 0.0 & 0.0 & 0.0 & 0.0 & \\
\hline Gypsum/Barite & 0.0 & 0.0 & 0.0 & 0.0 & 0.0 & 0.0 & 0.0 & \\
\hline Gypsum/Al-Si & 0.5 & 1.0 & 3.6 & 8.5 & 7.6 & 13.6 & 35.0 & \\
\hline Si-Rich & 0.1 & 0.3 & 0.2 & 0.2 & 0.3 & 0.1 & 1.2 & \\
\hline Ca-Rich & 0.0 & 0.0 & 0.1 & 0.0 & 0.1 & 0.0 & 0.2 & \\
\hline $\mathrm{Ca}-\mathrm{Si}$-Rich & 0.0 & 0.0 & 0.0 & 0.0 & 0.0 & 0.0 & 0.0 & \\
\hline Unclassified & 1.2 & 2.9 & 6.6 & 9.5 & 8.9 & 13.7 & 42.9 & \\
\hline Totals & 3.0 & 7.7 & 15.3 & 23.1 & 20.2 & 30.7 & 100.0 & \\
\hline
\end{tabular}


Table 22. (continued) - Sunflower Hulls

\begin{tabular}{|c|c|c|c|c|c|c|c|c|}
\hline Classification: & $1.0-2.2$ & $2.2-4.6$ & $4.6-10$ & $10-22$ & $22-46$ & $46-100$ & Totals & $\begin{array}{c}\mathrm{wt} \% \\
\text { Excluded }\end{array}$ \\
\hline Quartz & 0.0 & 0.1 & 0.1 & 0.0 & 0.0 & 0.1 & 0.3 & \\
\hline Iron Oxide & 0.3 & 0.2 & 1.0 & 0.9 & 0.0 & 0.0 & 2.3 & \\
\hline Periclase & 0.0 & 0.0 & 0.0 & 0.0 & 0.0 & 0.0 & 0.0 & \\
\hline Rutile & 0.0 & 0.0 & 0.0 & 0.0 & 0.0 & 0.0 & 0.0 & \\
\hline Alumina & 0.0 & 0.0 & 0.0 & 0.0 & 0.0 & 0.0 & 0.1 & \\
\hline Calcite & 0.0 & 0.2 & 0.1 & 0.0 & 0.1 & 0.0 & 0.4 & \\
\hline Dolomite & 0.0 & 0.0 & 0.0 & 0.0 & 0.1 & 0.0 & 0.1 & \\
\hline Ankerite & 0.0 & 0.0 & 0.0 & 0.0 & 0.0 & 0.0 & 0.0 & \\
\hline Kaolinite & 0.0 & 0.0 & 0.0 & 0.0 & 0.0 & 0.0 & 0.0 & \\
\hline Montmorillonite & 0.0 & 0.0 & 0.0 & 0.0 & 0.0 & 0.0 & 0.0 & \\
\hline K Al-Silicate & 0.0 & 0.1 & 0.2 & 0.1 & 0.0 & 0.0 & 0.4 & \\
\hline Fe Al-Silicate & 0.0 & 0.0 & 0.0 & 0.0 & 0.0 & 0.0 & 0.0 & \\
\hline Ca Al-Silicate & 0.0 & 0.0 & 0.0 & 0.0 & 0.0 & 0.0 & 0.0 & \\
\hline Na Al-Silicate & 0.0 & 0.0 & 0.0 & 0.0 & 0.0 & 0.0 & 0.0 & \\
\hline Aluminosilicate & 0.0 & 0.0 & 0.0 & 0.0 & 0.0 & 0.0 & 0.0 & \\
\hline Mixed Al-Si & 0.0 & 0.0 & 0.0 & 0.0 & 0.0 & 0.0 & 0.0 & \\
\hline Fe Silicate & 0.0 & 0.0 & 0.0 & 0.0 & 0.0 & 0.0 & 0.0 & \\
\hline Ca Silicate & 0.0 & 0.0 & 0.0 & 0.0 & 0.0 & 0.0 & 0.0 & \\
\hline $\mathrm{Ca}$ Aluminate & 0.0 & 0.0 & 0.0 & 0.0 & 0.0 & 0.0 & 0.0 & \\
\hline Pyrite & 0.0 & 0.0 & 0.0 & 0.0 & 0.0 & 0.0 & 0.0 & \\
\hline Pyrrhotite & 0.0 & 0.0 & 0.0 & 0.0 & 0.0 & 0.0 & 0.0 & \\
\hline Oxidized & 0.0 & 0.0 & 0.0 & 0.0 & 0.0 & 0.0 & 0.0 & \\
\hline \multicolumn{9}{|l|}{ Pyrrhotite } \\
\hline Gypsum & 0.0 & 0.0 & 0.0 & 0.0 & 0.0 & 0.0 & 0.0 & \\
\hline Barite & 0.0 & 0.0 & 0.0 & 0.0 & 0.0 & 0.0 & 0.0 & \\
\hline Apatite & 0.0 & 0.0 & 0.0 & 0.0 & 0.0 & 0.0 & 0.0 & \\
\hline Ca Al-Phosphate & 0.0 & 0.0 & 0.0 & 0.0 & 0.0 & 0.0 & 0.0 & \\
\hline $\mathrm{KCl}$ & 0.0 & 0.0 & 0.0 & 0.0 & 0.1 & 0.0 & 0.2 & \\
\hline Gypsum/Barite & 0.0 & 0.0 & 0.0 & 0.0 & 0.0 & 0.0 & 0.0 & \\
\hline Gypsum/Al-Si & 0.0 & 0.0 & 0.0 & 0.0 & 0.0 & 0.0 & 0.0 & \\
\hline Si-Rich & 0.0 & 0.0 & 0.1 & 0.5 & 0.0 & 0.0 & 0.6 & \\
\hline Ca-Rich & 0.0 & 0.1 & 0.0 & 0.0 & 0.1 & 0.0 & 0.2 & \\
\hline $\mathrm{Ca}-\mathrm{Si}$-Rich & 0.0 & 0.0 & 0.0 & 0.0 & 0.0 & 0.0 & 0.0 & \\
\hline Unclassified & 0.7 & 1.3 & 38.5 & 46.9 & 3.6 & 4.4 & 95.3 & \\
\hline Totals & 1.0 & 2.0 & 40.0 & 48.4 & 4.1 & 4.5 & 100.0 & \\
\hline
\end{tabular}


Table 23. Operating Conditions

\begin{tabular}{|c|c|c|c|}
\hline Test Number: & AF-CTS-Stoker01 & AF-CTS-Stoker02 & AF-CTS-Stoker03 \\
\hline Description: & $100 \%$ Cordero Rojo & 60-40 Cordero-Wood & 60-40 Cordero-Sunflower \\
\hline Date: & $1 / 17 / 02$ & $1 / 28 / 02$ & $2 / 7 / 02$ \\
\hline FEGT, ${ }^{\circ} \mathrm{F}$ & 1948 & 1899 & 1870 \\
\hline Fuel Feed Rate, lb/hr & 86.8 & 98.75 & 91.9 \\
\hline Firing Rate, Btu/hr & 810,427 & 859,964 & 817,721 \\
\hline \multicolumn{4}{|l|}{ Flue Gas Analysis } \\
\hline $\mathrm{O}_{2}, \%$ & 5.2 & 5.9 & 6.0 \\
\hline $\mathrm{CO}_{2}, \%$ & 14.0 & 13.6 & 13.8 \\
\hline $\mathrm{SO}_{2}, \mathrm{ppm}$ & 257 & 162 & 56 \\
\hline $\mathrm{NO}_{\mathrm{x}}, \mathrm{ppm}$ & 167 & 127 & 141 \\
\hline $\mathrm{CO}, \mathrm{ppm}$ & 41 & 77 & 52 \\
\hline Excess Air, \% & 33 & 39 & 40 \\
\hline \multicolumn{4}{|l|}{ Emissions at $5 \% \mathrm{O}_{2}$} \\
\hline $\mathrm{SO}_{2}, \mathrm{ppm}$ & 260 & 171 & 60 \\
\hline $\mathrm{NO}_{x}, \mathrm{ppm}$ & 169 & 134 & 151 \\
\hline \multicolumn{4}{|c|}{ System Temperatures, ${ }^{\circ} \mathrm{F}$} \\
\hline FD $^{1}$ Fan Outlet & 127 & 128 & 127 \\
\hline Primary Air & 338 & 341 & 339 \\
\hline Secondary Air & 351 & 348 & 349 \\
\hline Overfire Air E & 304 & 298 & 301 \\
\hline Overfire Air W & 284 & 285 & 283 \\
\hline FEGT & 1948 & 1899 & 1870 \\
\hline Probe Bank Exit & 1745 & 1736 & 1733 \\
\hline ESP Inlet & 326 & 315 & 314 \\
\hline ESP Outlet & 291 & 288 & 286 \\
\hline Stack & 233 & 227 & 224 \\
\hline \multicolumn{4}{|l|}{$\begin{array}{l}\text { System Pressures, in. } \\
\text { W.C. }\end{array}$} \\
\hline FD Fan Outlet Static & 82.4 & 83.1 & 82.7 \\
\hline Furnace Static & -0.4 & -0.3 & -0.3 \\
\hline ESP inlet Static & -6.2 & -6.4 & -6.1 \\
\hline ID $^{2}$ Fan Inlet Static & -13.7 & -13.3 & -13.4 \\
\hline \multicolumn{4}{|l|}{ Probe Bank Metal } \\
\hline Temperature, ${ }^{\circ} \mathrm{F}$ & 1024 & 1015 & 1014 \\
\hline
\end{tabular}

Comparisons at constant excess air $\left(5 \% \mathrm{O}_{2}\right)$ levels indicate that nitrogen oxide emissions were reduced by $20 \%$ and $10 \%$, respectively, during combustion of the wood chip and sunflower hull blends. Strictly based on fuel nitrogen content, the coal-wood chip blend would be expected to result in the lowest nitrogen oxide emission rate while the coal-sunflower hull blend should result in the highest nitrogen oxide emission rate. However, the highest nitrogen oxide emission rate was observed for the Cordero Rojo coal baseline test. The reason is believed to be relatively higher flame-furnace temperatures indicated by the higher FEGT $\left(1065^{\circ} \mathrm{C}\left[1948^{\circ} \mathrm{F}\right]\right)$ and lower average flue gas oxygen concentration (5.2\% dry) observed for the Cordero Rojo coal baseline test. 
Fuel feed was achieved by a reciprocating ram that pushed fuel under a metal gate at a rate to achieve the desired operating conditions. Blend level was controlled by a second refractory gate that allowed the biomass to be fed on top of the coal with each stroke of the ram. When operated with $100 \%$ coal, the feed system worked fairly well. The main problem encountered during shakedown tests was ash clinkering on the grate, which resulted in forced shutdowns. Changes made to the grate and sidewalls of the furnace (described earlier) significantly reduced the level of clinkering observed, but did not eliminate the problem. Very little fly ash was generated during any of the combustion tests.

Occasionally, removal of clinkers from the grate was necessary to maintain fuel flow and grate performance. Clinkers were formed of varying hardness and removed as bottom ash. To prevent the clinkers from completely fusing on the grate, a stainless steel poker was used to periodically agitate the bed and scrape any deposits forming on the sidewalls. As a result of this agitation, the intensity of the combustion increased dramatically and there were short periods of low excess air and high carbon carryover. Overall, carbon monoxide emissions were kept to a minimum, averaging less than 80 ppm (dry basis) for all tests.

As mentioned previously, consistent biomass feed was an issue, particularly with the wood chips. The fibrous nature and irregular shape of the wood chips created particles that packed well and bridged in the feed hopper. Periodic manual assistance was required to keep the wood chips flowing through the hopper. A finer feed size distribution or a separate feed system would most likely improve feeding characteristics. The sunflower hulls also tended to bridge in the feed hopper, but to a much lesser degree than the wood chips. Some assistance was required to maintain a consistent flow of sunflower hulls.

\section{Ash Deposit Formation}

Three stainless steel fouling probes were inserted into the refractory-lined duct at the furnace exit at the beginning of each test to assess the ash deposition characteristics for the baseline coal and the coal-biomass blends. Steam was used to control surface metal temperatures to that normally associated with steam generation in a utility boiler, $538^{\circ} \mathrm{C}\left(1000^{\circ} \mathrm{F}\right)$. Deposits were collected over a 5.25-hour test period. As mentioned previously, the majority of the ash was removed as bottom ash, forming clinkers of varying hardness that were either moved to the ash pit by the reciprocating motion of the feed ram or were pulled from the grate manually. Therefore, little fly ash was generated, resulting in minimal deposit formation on the probe bank. In each test, only a slight dusting of the probes was evident, with a total deposit weight of about 2 grams, indicating an extremely low deposition rate. Dusty deposits of this nature are generally formed when thermophoretic forces act on fine particulate, with these particles migrating to the cooler probe surface. The fouling deposits can be seen in Figures 21-23. At the end of each test, the deposits were removed from the probe in two layers, the inner "white" layer and the sinter layer. These samples were submitted for bulk compositional analyses using XRF, XRD, and SEMPC. Results from these analyses can be found in Tables 24-26.

As may be expected, the baseline Cordero Rojo deposit and the Cordero Rojo-wood chip deposits were made up primarily of silicates (quartz and clays) as shown in Table 25. Sulfate species were present at the $10 \%$ level (baseline) and the $15.9 \%$ level for the coal-wood chip blend. In contrast, the coal-sunflower hull blend deposit was made up primarily of sulfate species, accounting 


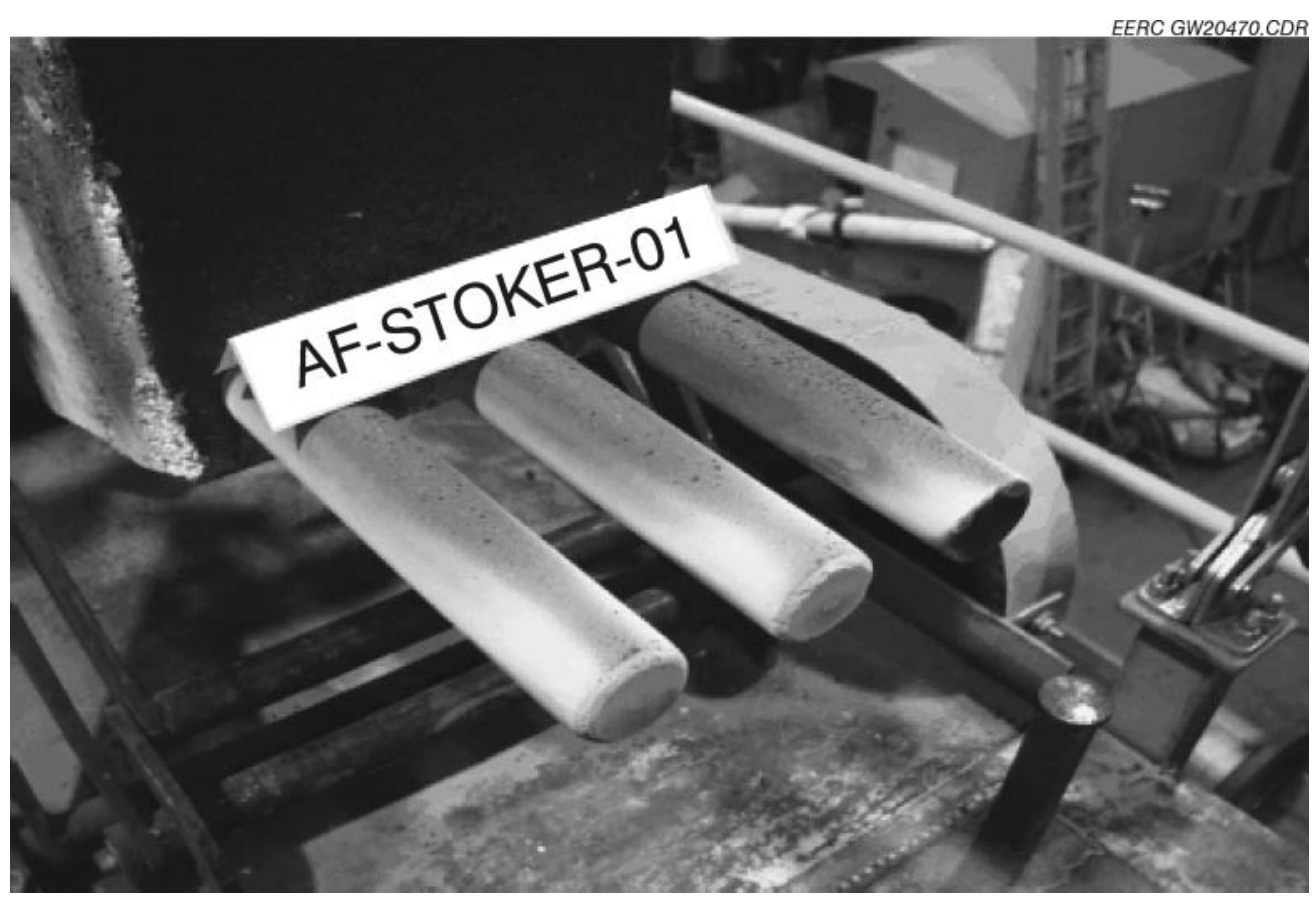

Figure 21. Photograph of fouling probe bank - AF-CTS-Stoker01 - baseline Cordero Rojo.

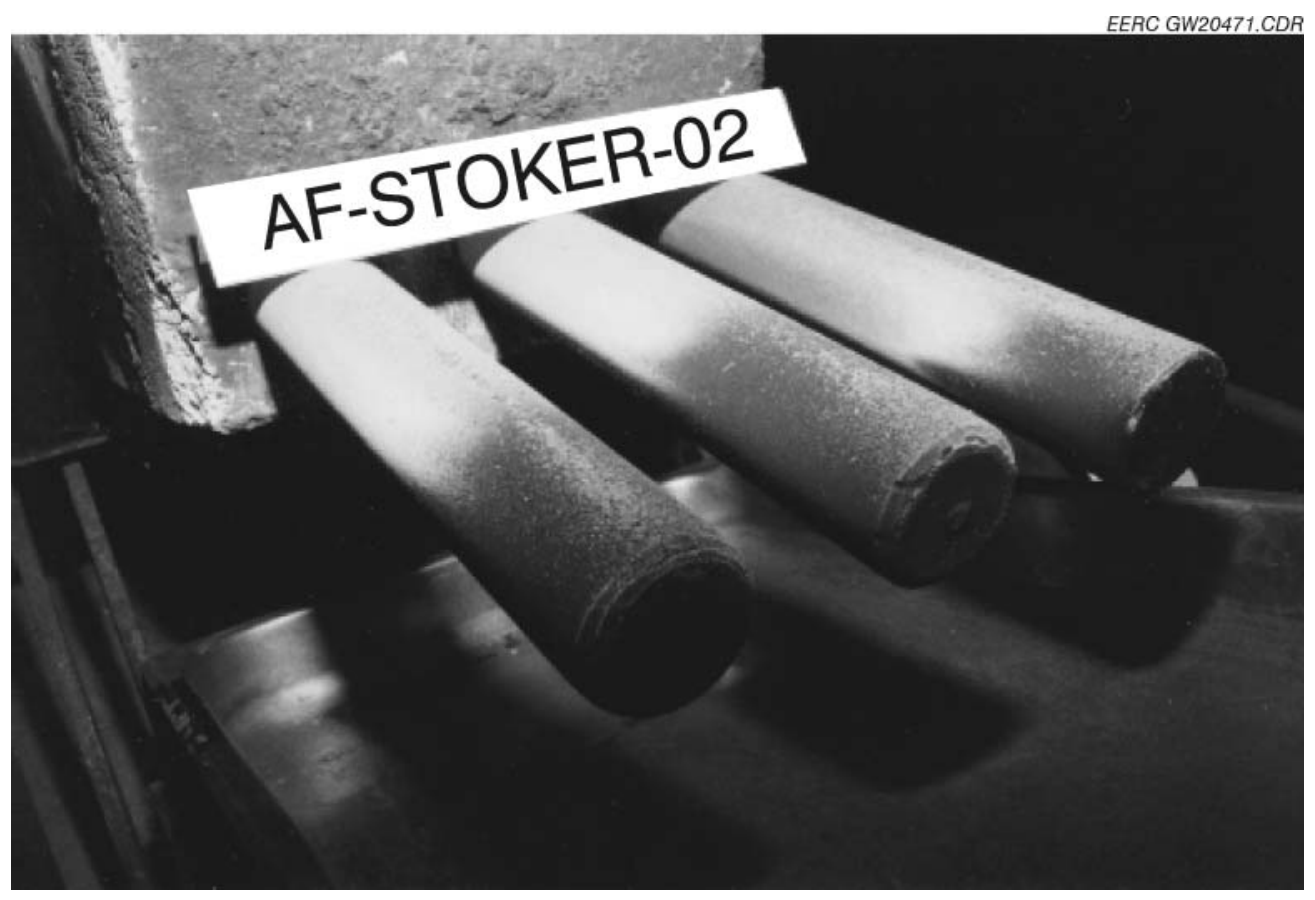

Figure 22. Photograph of fouling probe bank - AF-CTS-Stoker02 - 60-40 Cordero Rojo-wood chips. 


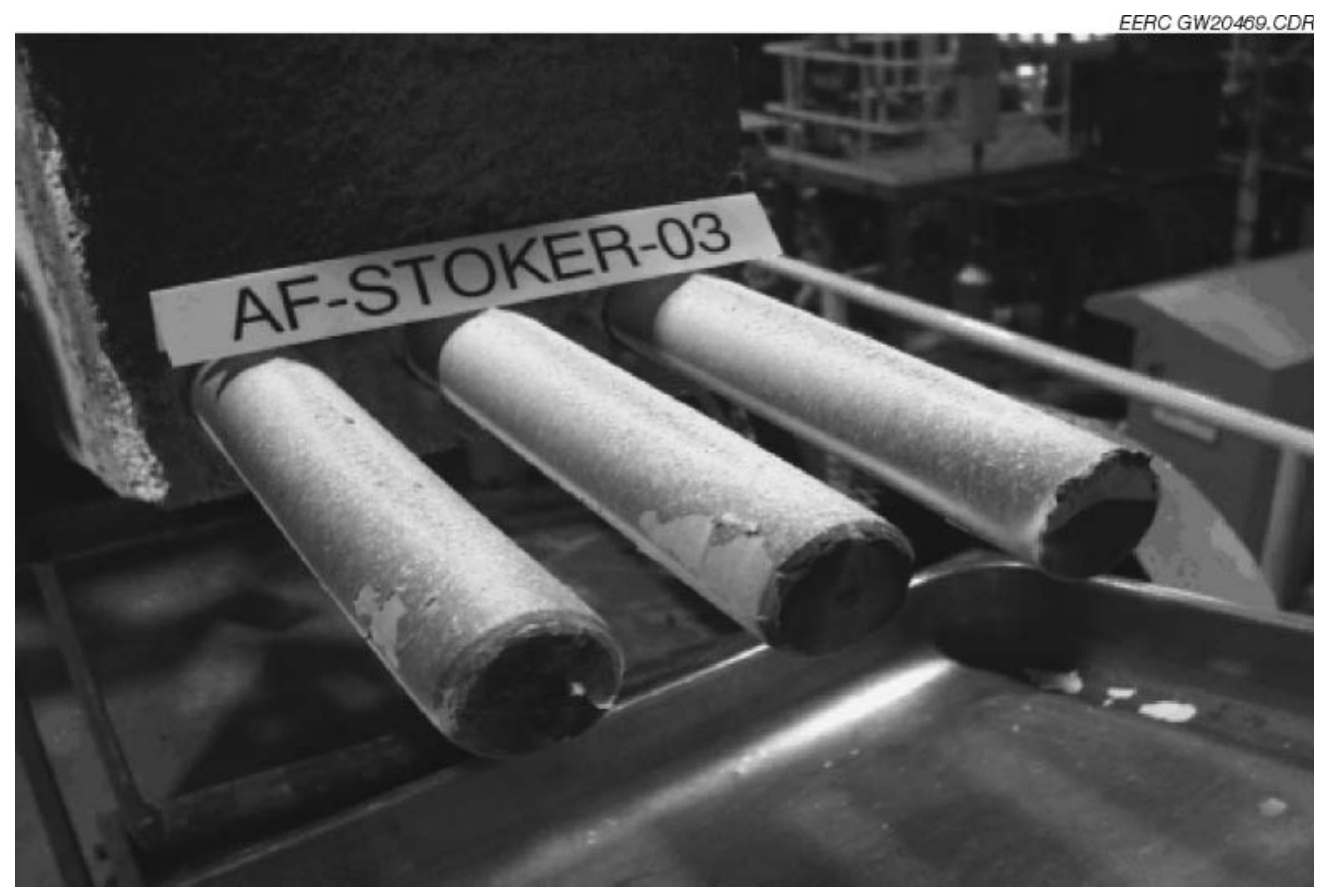

Figure 23. Photograph of fouling probe bank - AF-CTS-Stoker03 - 60-40 Cordero Rojo sunflower hulls.

for $56.0 \%$ of the total mass. XRD analyses (Table 26) indicated minor crystalline silicate phases for the baseline coal, a major anhydrite $\left(\mathrm{CaSO}_{4}\right)$ phase for the coal-wood chip blend, and major dolomite $\left(\mathrm{CaMg}\left[\mathrm{CO}_{3}\right]\right)$ and potassium sulfate hydrate $\left(\mathrm{K}_{2} \mathrm{SO}_{3} 2 \mathrm{H}_{2} \mathrm{O}\right)$ for the coal-sunflower hull blend. All deposits indicated the presence of $\mathrm{MgO}$.

Some notable compositional trends include a depletion in silica, alumina, and calcium and enrichment of potassium and sulfur when the blend deposits are compared with the baseline coal deposit, as shown in Table 24. Anorthite is present at the $1.9 \%$ level in the coal deposit, while the coal-wood chip blend deposit contained $0.8 \%$ and the coal-sunflower hull blend deposit $0.0 \%$ anorthite. Anorthite is a calcium aluminosilicate phase that requires high temperatures to form. Although present at a low percentage overall, its presence indicates more severe combustion conditions existed for the baseline coal than for either of the blends. This is also indicated by the reported FEGT for each test (Table 23), with the baseline gas temperature greater than that achieved during combustion of either fuel blend. In terms of interaction of species, it appears that the coal-wood blend had the greatest interaction between ash-forming species, as the mixed-silica-rich percentage increases from a baseline of $10.8 \%$ to $19.4 \%$. The mixed-silica-rich phase is generally an amorphous mixture of components that indicates the relative degree of melting in a deposit.

Based on the information generated here, each of the blend deposits would appear to be more problematic than the baseline coal. Each showed a greater fouling rate and produced more problematic phases, even though both were run at lower temperatures than the baseline Cordero Rojo. These results are most likely skewed to lower deposition rates because of the excessive clinker formation and low level of fly ash generated for each test. The high sulfate concentrations for the 
Table 24. Probe Bank Ash Fouling Results

\begin{tabular}{|c|c|c|c|c|c|c|}
\hline Test Number: & \multicolumn{2}{|c|}{ AF-CTS-Stoker01 } & \multicolumn{2}{|c|}{ AF-CTS-Stoker02 } & \multicolumn{2}{|c|}{ AF-CTS-Stoker03 } \\
\hline Fuel Description: & \multicolumn{2}{|c|}{$100 \%$ Cordero Rojo } & \multicolumn{2}{|c|}{ 60-40 Cordero-Wood } & \multicolumn{2}{|c|}{$\begin{array}{c}60-40 \\
\text { Cordero-Sunflower }\end{array}$} \\
\hline Test Date: & \multicolumn{2}{|c|}{$1 / 17 / 02$} & \multicolumn{2}{|c|}{$1 / 28 / 02$} & \multicolumn{2}{|c|}{$2 / 7 / 02$} \\
\hline $\mathrm{FEGT},{ }^{\circ} \mathrm{F}$ & & 1948 & & 1899 & & 1870 \\
\hline Probe Metal, ${ }^{\circ} \mathrm{F}$ & & 1024 & & 1015 & & 1014 \\
\hline Probe Bank Sinter, g & & 1.5 & & 2 & & 2.2 \\
\hline Probe Bank Inner, g & & 0.1 & & 0.1 & & 0.1 \\
\hline Deposition Rate & & & & & & \\
\hline grams $/ \mathrm{hr}$ & & 0.3 & & 0.4 & & 0.44 \\
\hline grams/kg-input ash & & 0.15 & & 0.27 & & 0.25 \\
\hline Deposit Analyses, \% & White & Sinter & White & Sinter & White & Sinter \\
\hline $\mathrm{SiO}_{2}$ & $\mathrm{~N} / \mathrm{A}$ & 26.1 & 13.7 & 11.6 & 2.59 & 8.78 \\
\hline $\mathrm{Al}_{2} \mathrm{O}_{3}$ & & 15.5 & 9.68 & 6.2 & 1.07 & 4.69 \\
\hline $\mathrm{Fe}_{2} \mathrm{O}_{3}$ & & 7.4 & 8.46 & 7.4 & 0.81 & 2.72 \\
\hline $\mathrm{TiO}_{2}$ & & 1.4 & 0.92 & 0.8 & 0.12 & 0.45 \\
\hline $\mathrm{P}_{2} \mathrm{O}_{5}$ & & 1.1 & 1.83 & 1.9 & 1.21 & 6.46 \\
\hline $\mathrm{CaO}$ & & 31.9 & 24.6 & 25.3 & 3.81 & 21.3 \\
\hline $\mathrm{MgO}$ & & 5.8 & 5.31 & 3.1 & 2.27 & 13.4 \\
\hline $\mathrm{Na}_{2} \mathrm{O}$ & & 3.8 & 5.58 & 14 & 5.59 & 2.06 \\
\hline $\mathrm{K}_{2} \mathrm{O}$ & & 0.3 & 4.47 & 5.8 & 51.1 & 23.6 \\
\hline $\mathrm{SO}_{3}$ & & 6.6 & 25.45 & 24 & 31.4 & 16.5 \\
\hline SEMPC Bulk & & $\mathrm{ClO} / \mathrm{SO}_{3}-$ & & $\mathrm{ClO} / \mathrm{SO}_{3}-$ & & $\mathrm{ClO} / \mathrm{SO}_{3}-$ \\
\hline Analysis & As-Rec'd & Free & As-Rec'd & Free & As-Rec'd & Free \\
\hline $\mathrm{SiO}_{2}$ & 23.1 & 40.8 & 17.9 & 20.2 & 7.1 & 9.7 \\
\hline $\mathrm{Al}_{2} \mathrm{O}_{3}$ & 7.4 & 13 & 10.9 & 12.3 & 2.7 & 3.7 \\
\hline $\mathrm{Fe}_{2} \mathrm{O}_{3}$ & 4 & 7 & 9.7 & 11 & 2 & 2.7 \\
\hline $\mathrm{TiO}_{2}$ & 0.8 & 1.5 & 1 & 1.1 & 0.5 & 0.7 \\
\hline $\mathrm{P}_{2} \mathrm{O}_{5}$ & 0.7 & 1.2 & 2.4 & 2.8 & 5.6 & 7.7 \\
\hline $\mathrm{CaO}$ & 18.2 & 32 & 37.4 & 42.4 & 22.3 & 30.4 \\
\hline $\mathrm{MgO}$ & 2.1 & 3.7 & 5.7 & 6.5 & 11.1 & 15.2 \\
\hline $\mathrm{Na}_{2} \mathrm{O}$ & 0.3 & 0.6 & 1.3 & 1.5 & 0.6 & 0.8 \\
\hline $\mathrm{K}_{2} \mathrm{O}$ & 0.2 & 0.3 & 1.9 & 2.2 & 21.4 & 29.2 \\
\hline $\mathrm{SO}_{3}$ & 8 & & 9.3 & & 24.4 & \\
\hline $\mathrm{ClO}$ & 34.1 & & 1.2 & & 1.7 & \\
\hline
\end{tabular}

N/A - Not enough sample to complete analysis.

coal-sunflower hull blend tend to indicate a greater potential for problematic deposition in the lowtemperature regions of a boiler. Based on fuel analyses, the coal-sunflower hull blend appeared to have the greatest potential for problematic deposition. It has a very high potassium concentration that is organically associated. In combination with the quartz and clays from the coal, greater deposition would be expected. Overall, the deposition noted as a result of these tests would not be considered problematic and would not be expected to greatly inhibit heat transfer through steam tubes. For comparison of the differences between these stoker-fired deposits and typical deposition seen during pc-fired operation, photographs of the pc-fired deposition for the baseline coal are provided in Figure 24. The pc-fired operating conditions were more severe $\left(\mathrm{FEGT}=1204^{\circ} \mathrm{C}\right.$ 
Table 25. Deposit Analyses: SEMPC

\begin{tabular}{|c|c|c|c|c|c|c|}
\hline Test Number: & \multicolumn{2}{|c|}{ AF-CTS-Stoker01 } & \multicolumn{2}{|c|}{ AF-CTS-Stoker02 } & \multicolumn{2}{|c|}{ AF-CTS-Stoker03 } \\
\hline Fuel Description: & \multicolumn{2}{|c|}{$100 \%$ Cordero Rojo } & \multicolumn{2}{|c|}{ 60-40 Cordero-Wood } & \multicolumn{2}{|c|}{ 60-40 Cord-Sunflower } \\
\hline Test Date: & \multicolumn{2}{|c|}{$1 / 17 / 02$} & \multicolumn{2}{|c|}{$1 / 28 / 02$} & \multicolumn{2}{|c|}{$2 / 7 / 02$} \\
\hline & Percent & Group Total & Percent & Group Total & Percent & Group Total \\
\hline \multicolumn{7}{|l|}{ SEMPC Analyses, \% } \\
\hline Oxide-Rich & & & & 11.5 & & 1.6 \\
\hline Magnesium Oxide & 0 & 2.7 & 0.4 & 11.5 & 0 & 1.6 \\
\hline Calcium Oxide & 0 & 2.7 & 5.2 & 11.5 & 0.4 & 1.6 \\
\hline Iron Oxide & 0.8 & 2.7 & 3.2 & 11.5 & 0 & 1.6 \\
\hline Mixed-Oxide-Rich & 1.9 & 2.7 & 2.8 & 11.5 & 1.2 & 1.6 \\
\hline Sulfur Rich & & 10 & & 15.9 & & 56 \\
\hline Pyrite & 1.5 & 10 & 0.4 & 15.9 & 0.4 & 56 \\
\hline Calcium Sulfate & 0 & 10 & 0.8 & 15.9 & 0 & 56 \\
\hline Mixed-Sulfur-Rich & 8.5 & 10 & 14.7 & 15.9 & 55.6 & 56 \\
\hline Phosphorus-Rich & 0 & 0 & 1.2 & 1.2 & 7.2 & 7.2 \\
\hline Mixed-Phosph. Rich & 0 & 0 & 1.2 & 1.2 & 7.2 & 7.2 \\
\hline Carbon-Rich & & 38.6 & & 4 & & 6.4 \\
\hline Calcite & 0.4 & & 2 & & 5.6 & \\
\hline Mixed-Carbon-Rich & 38.2 & 38.6 & 2 & 4 & 0.8 & 6.4 \\
\hline Metal-Rich & 9.7 & 9.7 & 1.2 & 1.2 & 2.4 & 2.4 \\
\hline Mixed-Metal-Rich & 9.7 & 9.7 & 1.2 & 1.2 & 2.4 & 2.4 \\
\hline Silicon-Rich & & 24.3 & & 32.9 & & 6.4 \\
\hline Quartz & 2.7 & & 2.8 & & 0.4 & \\
\hline Anorthite & 1.9 & & 0.8 & & 0 & \\
\hline Kaolinite & 0.8 & & 0.8 & & 0 & \\
\hline Illite & 0.4 & & 2 & & 0 & \\
\hline Montmorillonite & 1.5 & & 0.4 & & 0 & \\
\hline Pyroxene & 1.2 & & 1.2 & & 0.8 & \\
\hline Wollastonite & 0.4 & & 0 & & 0 & \\
\hline Ca-Silicate & 1.2 & & 2 & & 0 & \\
\hline Gehlinite & 1.5 & & 0.8 & & 0.8 & \\
\hline Akerminite & 0 & & 0.4 & & 0 & \\
\hline Spurrite & 0.8 & & 2.4 & & 0 & \\
\hline Mixed-Silicon-Rich & 10.8 & 24.3 & 19.4 & 32.9 & 4.4 & 6.4 \\
\hline \multicolumn{7}{|l|}{ Calcium } \\
\hline Aluminosilicate & 1.2 & 1.2 & 1.2 & 1.2 & 0.4 & 0.4 \\
\hline \multicolumn{7}{|l|}{ SEMPC Bulk } \\
\hline Analysis & As-Rec'd & $\mathrm{ClO} / \mathrm{SO}_{3}$-free & As-Rec'd & $\mathrm{ClO} / \mathrm{SO}_{3}$-free & As-Rec'd & $\mathrm{ClO} / \mathrm{SO}_{3}$-free \\
\hline $\mathrm{SiO}_{2}$ & 23.1 & 40.8 & 17.9 & 20.2 & 7.1 & 9.7 \\
\hline $\mathrm{Al}_{2} \mathrm{O}_{3}$ & 7.4 & 13 & 10.9 & 12.3 & 2.7 & 3.7 \\
\hline $\mathrm{Fe}_{2} \mathrm{O}_{3}$ & 4 & 7 & 9.7 & 11 & 2 & 2.7 \\
\hline $\mathrm{TiO}_{2}$ & 0.8 & 1.5 & 1 & 1.1 & 0.5 & 0.7 \\
\hline $\mathrm{P}_{2} \mathrm{O}_{5}$ & 0.7 & 1.2 & 2.4 & 2.8 & 5.6 & 7.7 \\
\hline $\mathrm{CaO}$ & 18.2 & 32 & 37.4 & 42.4 & 22.3 & 30.4 \\
\hline $\mathrm{MgO}$ & 2.1 & 3.7 & 5.7 & 6.5 & 11.1 & 15.2 \\
\hline $\mathrm{Na}_{2} \mathrm{O}$ & 0.3 & 0.6 & 1.3 & 1.5 & 0.6 & 0.8 \\
\hline $\mathrm{K}_{2} \mathrm{O}$ & 0.2 & 0.3 & 1.9 & 2.2 & 21.4 & 29.2 \\
\hline $\mathrm{SO}_{3}$ & 8 & & 9.3 & & 24.4 & \\
\hline $\mathrm{ClO}$ & 34.1 & & 1.2 & & 1.7 & \\
\hline
\end{tabular}


Table 26. XRD Analyses of Sinter Deposits

\begin{tabular}{|c|c|c|c|}
\hline Test Number: & AF-CTS-Stoker01 & AF-CTS-Stoker02 & AF-CTS-Stoker03 \\
\hline Fuel Description: & $100 \%$ Cord. Rojo & 60-40 Cord.-Wood & $\begin{array}{c}60-40 \\
\text { Cord.-Sunflower }\end{array}$ \\
\hline Test Date: & $1 / 17 / 02$ & $1 / 28 / 02$ & $2 / 7 / 02$ \\
\hline Quartz, $\mathrm{SiO}_{2}$ & Minor & Minor & \\
\hline Merwinite, $\mathrm{Ca}_{3} \mathrm{Mg}\left(\mathrm{SiO}_{4}\right)_{2}$ & Minor & Minor & \\
\hline Periclase, $\mathrm{MgO}$ & Minor & Minor & Major \\
\hline Dolomite, $\mathrm{CaMg}\left(\mathrm{CO}_{3}\right)_{2}$ & & & Major \\
\hline $\begin{array}{l}\text { Potassium Sulfate Hydrate, } \\
\mathrm{K}_{2} \mathrm{SO}_{3} 2 \mathrm{H}_{2} \mathrm{O}\end{array}$ & & & Major \\
\hline Calcium Silicate, $\mathrm{Ca}_{2} \mathrm{SiO}_{4}$ & & Minor & \\
\hline Hematite, $\mathrm{Fe}_{2} \mathrm{O}_{3}$ & & Minor & \\
\hline Maghemite, $\mathrm{Fe}_{2} \mathrm{O}_{3}$ & Minor & & \\
\hline Sodium Sulfate, $\mathrm{Na}_{2} \mathrm{SO}_{4}$ & & Minor & \\
\hline Potassium Sulfate, $\mathrm{K}_{2} \mathrm{~S}_{2} \mathrm{O}_{8}$ & & & Minor \\
\hline Possible Oldhamite, CaS & & Minor & \\
\hline Hydroxylapatite, $\mathrm{Ca}_{5}\left(\mathrm{PO}_{4}\right)_{3}(\mathrm{OH})$ & & & Minor \\
\hline Gehlenite, $\mathrm{Ca}_{2} \mathrm{Al}_{2} \mathrm{SiO}_{7}$ & Minor & & \\
\hline Anhydrite, $\mathrm{CaSO}_{4}$ & Minor & Major & Minor \\
\hline
\end{tabular}

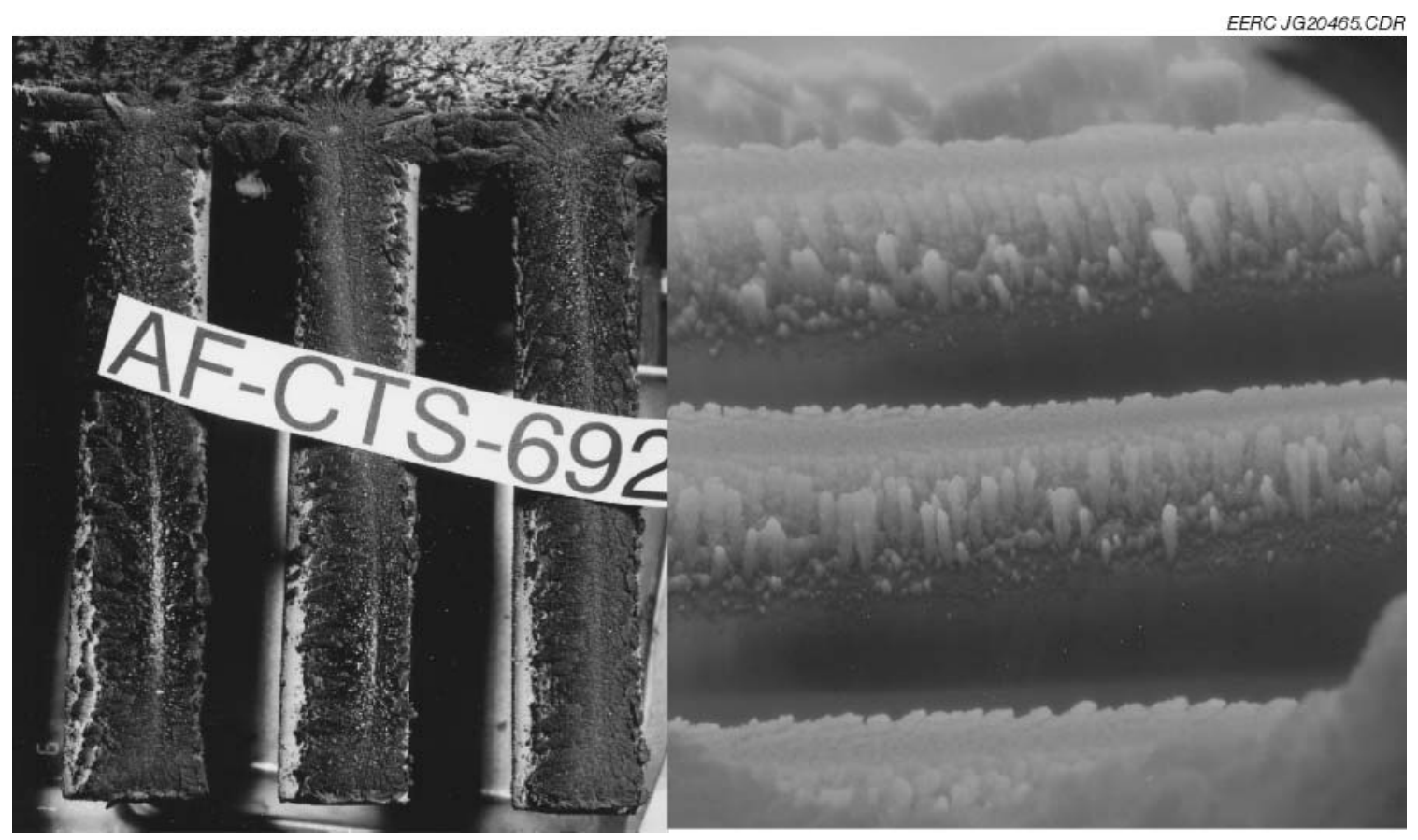

Figure 24. Cordero Rojo deposit in CTF - pc-fired $-1204^{\circ} \mathrm{C}\left(2200^{\circ} \mathrm{F}\right)$. 
$\left.\left[2200^{\circ} \mathrm{F}\right]\right)$ than those utilized during this stoker test series (FEGT $\left.<1093^{\circ} \mathrm{C}\left[2000^{\circ} \mathrm{F}\right]\right)$. The ashspecific deposition rate was 44.09 g-deposit/kg-input ash. The photo on the left indicates some leading-edge melting (dark, black, glassy portions) under these operating conditions. Because it is not molten everywhere, the fly ash is at or very near the critical temperature for problematic ash deposition. This deposit was considered low fouling with moderate strength. The baseline coal under similar conditions used in the stoker-fired tests $\left(\mathrm{FEGT} \leq 1093^{\circ}\left[2000^{\circ} \mathrm{F}\right]\right)$ would produce a smallerto similar-size deposit with much lower-strength characteristics over the same test duration.

\section{Bottom Ash and Fly Ash}

The majority of all noncombustible materials generated during combustion of the baseline coal and coal-biomass blends ended up as bottom ash. An ash mass balance is provided in Table 27 for each test. In all, over $93 \%$ of all ash collected was either bottom ash or on the walls of the combustor. ESP ash was $1.8 \%, 0.9 \%$, and $4.2 \%$ of the total collected, respectively, for the baseline coal, coal-wood chip blend, and coal-sunflower hull blend. Analyses of these ash samples are summarized in Table 28. Relative to the fly ash in each test, the bottom ash was significantly higher in silica and depleted in the alkali metals and sulfur. This indicates that the majority of the alkaline species were volatilized and ended up as fine particulate, primarily sulfates.

Carbon carryover was shown to increase from $3.6 \%$ for the baseline coal to $7.46 \%$ and $12.63 \%$, respectively, for the coal-wood chip and coal-sunflower hull blends. The dramatic increase in carbon carryover is most likely due to the more aggressive nature with which the clinkers were scraped from the combustor grate and walls during the biomass tests. When agitating the fuel bed to remove clinker, combustion conditions became more intense and excess air levels dropped dramatically, resulting in increased $\mathrm{CO}$ production and higher carbon carryover. This is an operational issue that the EERC has yet to completely resolve.

Fly ash size was determined by Malvern analysis for each test, and a trend toward finer size fractions was indicated when firing a coal-biomass blend. The analyses in Table 28 show that $90 \%$ of fly ash species during the baseline test were less than $36 \mu \mathrm{m}$. In comparison, the coal-wood chip blend was less than $29 \mu \mathrm{m}$ and the coal-sunflower hull blend about $19 \mu \mathrm{m}$. Plots of the analyses are provided in Figures 25-27. In addition, the baseline coal showed a normal distribution curve around the $\mathrm{D}_{50}$ of $16.83 \mu \mathrm{m}$. Each of the biomass blends showed bimodal distributions, with maximums at

Table 27. Ash Mass Balance

\begin{tabular}{|c|c|c|c|c|c|c|}
\hline Test Number: & \multicolumn{2}{|c|}{ AF-CTS-Stoker01 } & \multicolumn{2}{|c|}{ AF-CTS-Stoker02 } & \multicolumn{2}{|c|}{ AF-CTS-Stoker03 } \\
\hline Fuel Description: & $100 \% \mathrm{C}$ & ero Rojo & $60-40 \mathrm{Co}$ & -Wood & $60-40 \mathrm{Co}$ & inflower \\
\hline Test Date: & & & & & & \\
\hline Ash Input, g & 11,145 & & 9,907 & & 10,837 & \\
\hline Bottom Ash, g & 10,067 & $84.5 \%$ & 10,766 & $88.3 \%$ & 8083 & $82.3 \%$ \\
\hline Combustor Ash, g & 1468 & $12.3 \%$ & 1250 & $10.3 \%$ & 1104 & $11.2 \%$ \\
\hline Deposits, $g$ & 1.6 & & 2.1 & & 2.3 & \\
\hline HX and Duct Ash, g & 160 & $1.3 \%$ & 68 & $0.6 \%$ & 223 & $2.3 \%$ \\
\hline ESP Ash, g & 217 & $1.8 \%$ & 104 & $0.9 \%$ & 411 & $4.2 \%$ \\
\hline Total Ash Collected, g & 11,914 & & 12,190 & & 9823 & \\
\hline
\end{tabular}


Table 28. Bottom Ash and Fly Ash Analyses

\begin{tabular}{|c|c|c|c|c|c|c|}
\hline Test Number: & \multicolumn{2}{|c|}{ AF-CTS-Stoker01 } & \multicolumn{2}{|c|}{ AF-CTS-Stoker02 } & \multicolumn{2}{|c|}{ AF-CTS-Stoker03 } \\
\hline Fuel Description: & \multicolumn{2}{|c|}{$100 \%$ Cordero Rojo } & \multicolumn{2}{|c|}{$\begin{array}{c}60-40 \\
\text { Cordero-Wood }\end{array}$} & \multicolumn{2}{|c|}{$\begin{array}{c}60-40 \\
\text { Cordero-Sunflower }\end{array}$} \\
\hline \multirow{2}{*}{ Test Date: } & \multicolumn{2}{|c|}{$\begin{array}{c}1 / 17 / 02 \\
\end{array}$} & \multicolumn{2}{|c|}{$1 / 28 / 02$} & \multicolumn{2}{|c|}{$2 / 7 / 02$} \\
\hline & Bottom & ESP & Bottom & ESP & Bottom & ESP \\
\hline \multicolumn{7}{|l|}{ Inorganics, $\%$} \\
\hline $\mathrm{SiO}_{2}$ & 48.2 & 33.2 & 47.5 & 24.8 & 29.3 & 9.06 \\
\hline $\mathrm{Al}_{2} \mathrm{O}_{3}$ & 20.6 & 18.9 & 18.4 & 14.7 & 12.9 & 4.85 \\
\hline $\mathrm{Fe}_{2} \mathrm{O}_{3}$ & 6.6 & 10.9 & 5.6 & 11.2 & 4.62 & 2.89 \\
\hline $\mathrm{TiO}_{2}$ & 1.8 & 1.3 & 1.9 & 1.2 & 1.37 & 0.35 \\
\hline $\mathrm{P}_{2} \mathrm{O}_{5}$ & 0.4 & 1.1 & 0.6 & 1.4 & 6.05 & 7.29 \\
\hline $\mathrm{CaO}$ & 17.7 & 22.7 & 20.7 & 32.3 & 24 & 19 \\
\hline $\mathrm{MgO}$ & 3.2 & 3.6 & 3.9 & 5.1 & 9.52 & 11.8 \\
\hline $\mathrm{Na}_{2} \mathrm{O}$ & 0.7 & 2.3 & 0.9 & 2 & 1.15 & 3.29 \\
\hline $\mathrm{K}_{2} \mathrm{O}$ & 0.6 & 0.8 & 0.5 & 1 & 7.9 & 25.5 \\
\hline $\mathrm{SO}_{3}$ & 0 & 5.2 & 0.1 & 6.3 & 3.16 & 16 \\
\hline Carbon Content, \% & 2.72 & 3.60 & 1.44 & 7.46 & 27.45 & 12.63 \\
\hline \multicolumn{7}{|l|}{ ESP Fly Ash Size, $\mu \mathrm{m}$} \\
\hline Malvern, $\mathrm{D}_{50}$ & \multicolumn{2}{|c|}{16.83} & \multicolumn{2}{|c|}{11.24} & \multicolumn{2}{|c|}{6.98} \\
\hline Malvern, $\mathrm{D}_{90}$ & \multicolumn{2}{|c|}{35.98} & \multicolumn{2}{|c|}{28.64} & \multicolumn{2}{|c|}{19.28} \\
\hline
\end{tabular}

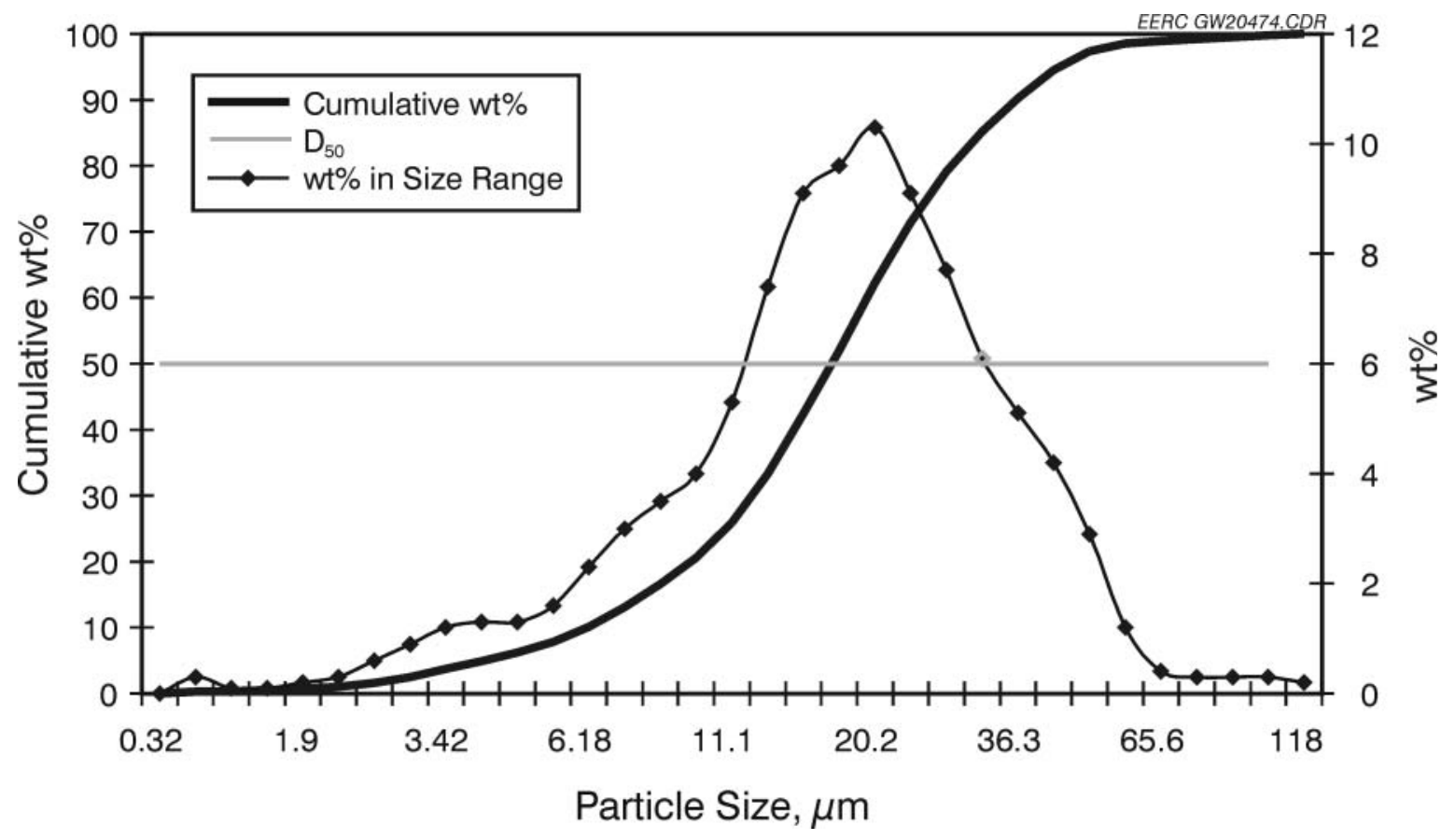

Figure 25. Fly ash-size distribution by Malvern analysis - baseline Cordero Rojo. 


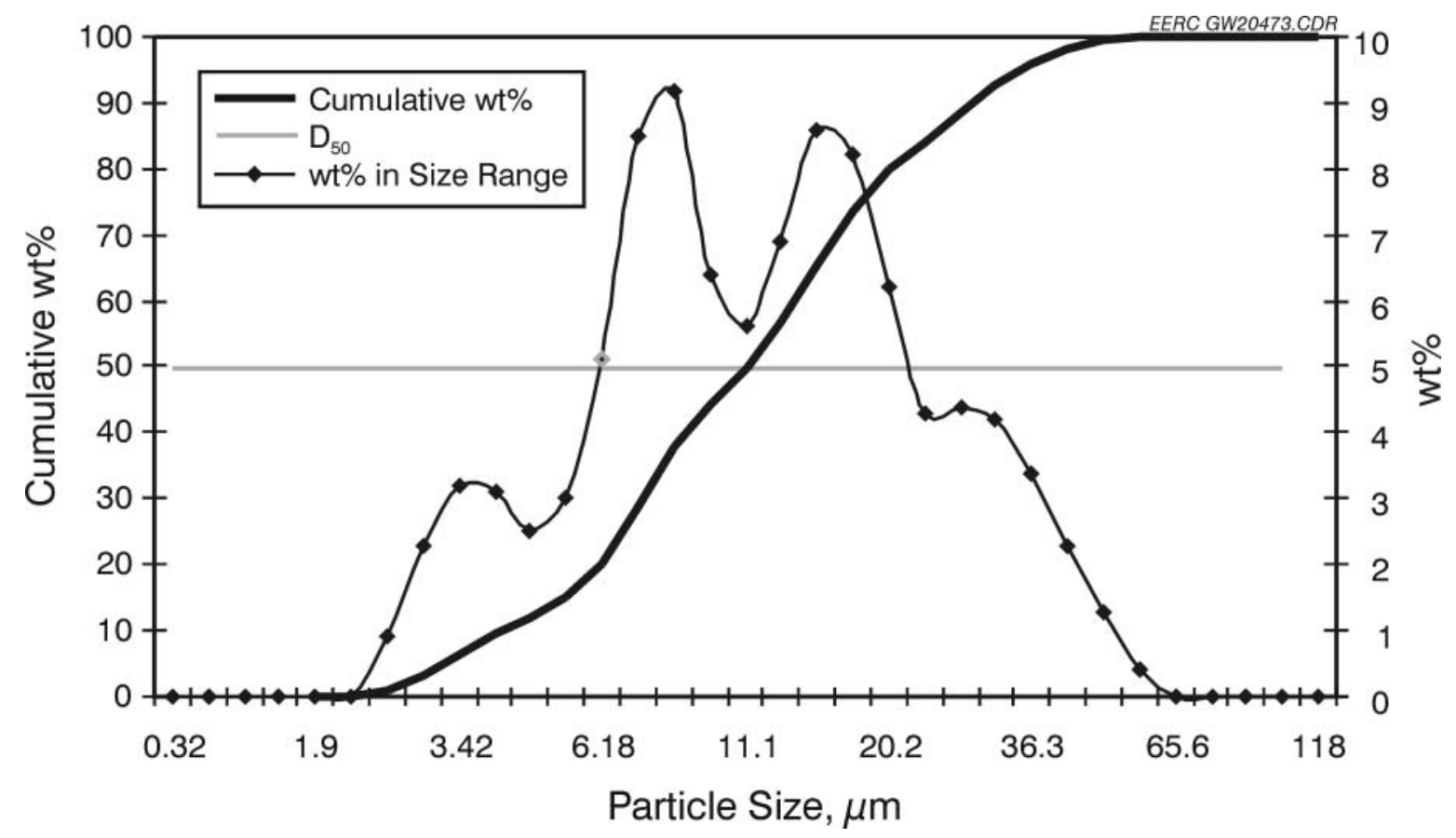

Figure 26. Fly ash-size distribution by Malvern analysis - 60-40 Cordero Rojo-wood chips.

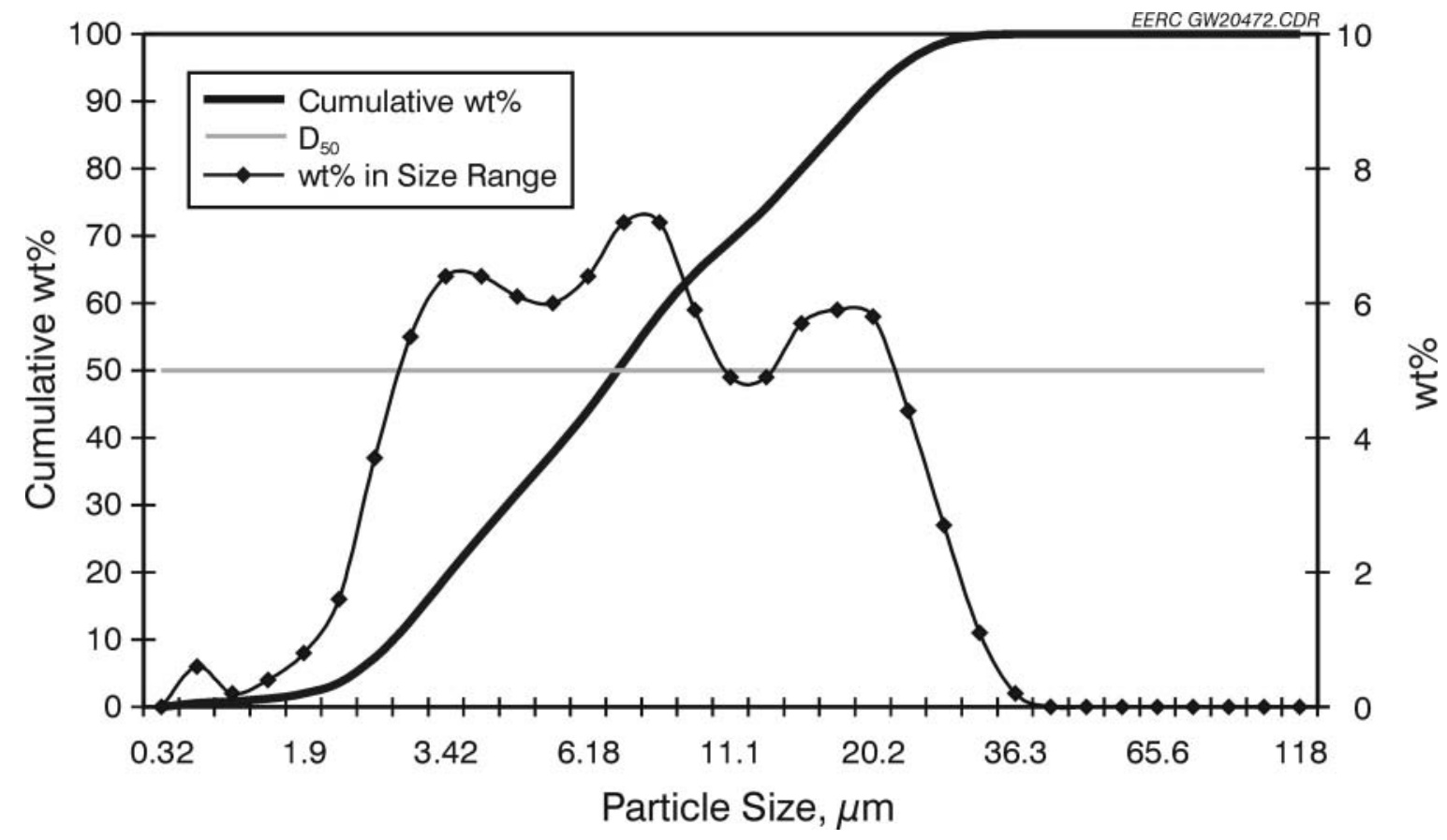

Figure 27. Fly ash-size distribution by Malvern analysis - 60-40 Cordero Rojo-sunflower hulls. 
about $15 \mu \mathrm{m}$ and $7 \mu \mathrm{m}$, respectively, for the coal-wood chip and coal-sunflower hull blends. This shift to a finer particle size could be problematic for units with small precipitators or, in some cases, old stokers still using multicyclones for particulate control.

\subsection{CONCLUSIONS AND RECOMMENDATIONS}

\section{Task 2 - Modification of Pilot-Scale Combustion System}

Existing storage bunkers at the EERC were not appropriate for use with most biomass fuels because they were designed for coal. Therefore, the EERC purchased a used walking-floor semitrailer. The over-the-road trailer could be used to pick up a quantity of biomass at a commercial site as well as meet on-site storage requirements.

The EERC also purchased a new agricultural forage box with a front-rear combination unloading capability. The forage box will be used for storage of small quantities of biomass fuel. However, its primary use will be to transfer biomass fuel from storage to processing equipment.

Proper fuel sizing at reasonable capacity was the highest priority with respect to fuel preparation. After reviewing options, the EERC elected to procure a rebuilt hammer mill, a quickchange half-screen unit, with the capability to size biomass down to $<0.318 \mathrm{~cm}(<0.125 \mathrm{in}$.) and discharge product through an outlet blower or gravity chute. Processing kiln-dried hardwood scraps into wood chips resulted in a product rate of $227 \mathrm{~kg} / \mathrm{hr}(500 \mathrm{lb} / \mathrm{hr})$. Straw/grass-type biomass was also processed in the hammer mill, but the small quantity of material processed did not lend itself to determination of a product mass rate. Softwood and straw/grass-type biomass should result in a product rate of at least $454 \mathrm{~kg} / \mathrm{hr}(1000 \mathrm{lb} / \mathrm{hr})$.

The EERC's CTF was successfully modified to simulate a grate-fired system (CTF-stoker). However, the modifications made will not prevent future operation of the pilot-scale combustion system in an entrained-firing configuration. The final design resulted in a rectangular grate with a surface area of $0.12 \mathrm{~m}^{2}$, or $1.25 \mathrm{ft}^{2}(25 \times 46 \mathrm{~cm}$, or $10 \mathrm{in} . \times 18 \mathrm{in}$. $)$, in order to match the grate size to the combustion system firing rate (nominally $0.58 \mathrm{~kJ} / \mathrm{hr}$, or $0.55 \mathrm{MMBtu} / \mathrm{hr}$ ). The resulting grate area on a firing rate basis was $0.21 \mathrm{~m}^{2} / \mathrm{GJ}\left(2.27 \mathrm{ft}^{2} / \mathrm{MMBtu}\right)$. Grate open area is $3.43 \%$.

The fixed-grate arrangement required the use of a ram to periodically move fuel and ash across the grate. Ram actuation frequency and stroke length vary depending on the fuel properties, firing rate, and whether a single fuel is fired or fuel cofiring is required. The fuel feed system makes use of a gravity feed dual-hopper-gate arrangement that permits the distribution of fuel on the fixed grate to a desired level for a given fuel particle size and heating value. Changes in fuel feed rate are made using a combination of adjustments to the elevation of the fuel gates and the operating frequency and stroke length of the ram over the fixed grate.

Primary combustion airflow to the grate is controlled and divided into four zones over the length of the grate representing $18 \%, 30 \%, 28 \%$, and $24 \%$ of the grate area, respectively. Overfire air is injected through multiple opposing ports about $71 \mathrm{~cm} \mathrm{(28} \mathrm{in.)} \mathrm{above} \mathrm{the} \mathrm{grate.} \mathrm{Primary} \mathrm{and}$ overfire air represent $80 \%-90 \%$ and $10 \%-20 \%$ of the total combustion air, respectively. The refractory-lined combustor is preheated by firing natural gas prior to initiating solid fuel firing. 


\section{Task 3 - Verification Testing of the Simulator}

Shakedown tests demonstrated that the fuel feed system worked as designed when feeding a single fuel such as the subbituminous coal. Coal was initially sized to $-2.5 \mathrm{~cm}(-1.0 \mathrm{in}$. $)$ and $+0.64 \mathrm{~cm}(+0.25 \mathrm{in}$.). However, shakedown tests indicated that a smaller top-size $(1.9 \mathrm{~cm}$, or 0.75 in.) improved pilot-scale grate-fired system performance. The improvement in performance with reduced coal top size is characteristic of the scale at which this project was conducted and not indicative of coal size requirements for commercial grate-fired systems. Full-scale grate-fired systems effectively use coal top sized to $5 \mathrm{~cm}(2 \mathrm{in}$.) and larger.

When initially attempting to cofire wood chips, wood chip feed was inconsistent because of bridging in the fuel hopper. This problem was mitigated to a significant degree as a result of reprocessing the wood chips through the hammer mill to eliminate oversized material (wood chips having a length-to-diameter ratio of $>2$ ). As with the coal, problems with oversized wood chips were more a characteristic of the scale at which this project was conducted and not indicative of fuel size requirements for commercial grate-fired systems. EERC experience with wood chip firing in an industrial grate-fired system indicates that a nominal 5-cm (2-in.) product from a hammer mill would be acceptable while limiting undersized material $(-0.64 \mathrm{~cm}$, or $-0.25 \mathrm{in}$.) to avoid excessive fuel entrainment from the grate.

Pilot-scale tests cofiring sunflower hulls demonstrated that the sunflower hulls fed more consistently through the gravity-based feed system than the wood chips because of their more uniform size distribution and generally less angular shape. EERC experience evaluating sunflower hull firing in an industrial grate-fired system determined that sizing of the sunflower hulls was not necessary and the sunflower hulls could be blended and fed with the coal using existing equipment. However, some modification of overfire airflow rate and distribution would be appropriate in order to optimize cofiring sunflower hulls, and some equipment upgrades may be necessary to control fugitive dust when blending sunflower hull-type biomass with coal.

A modification to the ram improved the performance of the pilot-scale fuel feed system as a result of an increased ram stroke frequency for a given fuel firing rate.

Initial shakedown tests resulted in excessive ash clinkering on the grate. Ash clinkers initiated along the refractory walls adjacent to the grate and propagated across the grate surface. Modifications to mitigate ash clinkering included fabricating a new grate with water-cooled tubing added to the air plenum side of the grate to improve grate thermal protection, adding water-cooled surfaces to the refractory walls adjacent to the grate, and adding two additional sight ports to improve the ability to observe and access the grate on-line. Although clinkering on the grate was not eliminated, it was reduced to a point that permitted the successful completion of grate-fired tests.

Further modifications to the pilot-scale grate-fired system in the future are likely to improve performance and increase flexibility. Operational changes would further reduce grate clinkering and result in other improvements in overall combustor performance. Some of these fuel-specific parameters include reducing fuel particle size, reducing the thickness of the fuel bed on the grate, and changes in primary and overfire air distribution. 


\section{Task 4 - Laboratory-Scale Testing and Fuel Characterization}

The biomass samples fired had a much lower moisture content than the coal but twice as much volatile matter. The fixed carbon for both the wood chips and the sunflower hulls was less than half of the Cordero Rojo coal.

The sunflower hulls had almost twice the inorganic content as the coal, while the wood chips contained a very low percentage of inorganics, $0.63 \%$. This is almost an order of magnitude lower than the coal and the sunflower hulls. The inorganic distribution in the wood and coal is fairly similar, with the exception of the wood being enriched in alkali and alkaline-earth elements and the coal having a higher sulfur level. The sunflower hulls, on the other hand, contained significantly higher phosphorus and potassium than the coal, with almost $60 \%$ potassium and $8 \%$ phosphorus. The hulls have much less silica, alumina, and calcium compared to the coal and wood. The majority of the inorganic material found to be leachable by water and ammonium acetate is in water-soluble form rather than organically associated as in coals. Generally, these materials will be more reactive than coal minerals because of a smaller size range but less reactive than organically associated materials.

Nitrogen content in the sunflower hulls was similar to that of the coal. The wood nitrogen level was nearly an order of magnitude lower. Fuel sulfur levels were $0.35 \%$ in the coal, $0.27 \%$ in the hulls, and $0.18 \%$ in the wood.

Chlorine levels in the biomass fuels were significantly higher at 588 and $649 \mathrm{ppm}$ in the hulls and wood, respectively, while the coal only contained $57 \mathrm{ppm}$ (all on an as-received basis). This high chlorine content could potentially be a corrosion problem and should be investigated thoroughly before implementing plans to cofire or blend biomass with coal.

Entrained fly ash and deposits were obtained in the CEPS combustor for the parent coal and coal-biomass blends of $80-20$ and $60-40$ on a weight basis. The deposits were collected on removable cooled probes for analysis and determination of growth rates and deposit strength.

The highest deposit growth rate was observed for the baseline coal-fired test. This deposit, however, had the lowest strength of any of the deposits generated. The highest-strength deposit was observed for the 60-40 Cordero Rojo-sunflower hull blend, which also had the lowest growth rate.

Analysis of the 60-40 coal-sunflower hull blend deposit showed a potassium-calciumaluminosilicate bonding matrix essentially "gluing" the deposit together. The high concentration of potassium in the sunflower hulls, reacted with the abundant calcium-aluminosilicates derived from the coal, led to lower-melting-point phases of lower viscosity which tend to increase strength development in ash deposits.

Analysis of the 60-40 coal-wood chip blend deposit showed a calcium-iron-aluminosilicate bonding matrix with iron crystallizing out of the melt. The crystallization of the iron can decrease the strength of the melt by creating areas that fracture more readily. The low ash content of the wood chips also contributed to a lower ash deposition rate and strength. 
PSD gives some clues as to growth and strength development. Previous work conducted at the EERC indicated that biomass fuels tend to have inorganic constituents that are significantly smaller than those observed in coal, and this is what is seen with these biomass fuels. In-flight flue gas particle-sizing analysis showed smaller particles for the 60-40 coal-sunflower hulls and 60-40 coal-wood chip blends, when compared to the Cordero Rojo coal.

The fly ash size distribution data indicate a potential for opacity problems due to the smaller fly ash size of blended fuels. This is also an area that needs to be investigated further in light of current and future particulate emission regulations.

The nitrogen content was relatively the same for the coal and the sunflower hulls but much lower in the wood. However, this was not reflected in the $\mathrm{NO}_{\mathrm{x}}$ emissions observed in the laboratoryscale combustion system. All of the coal-biomass blends resulted in higher $\mathrm{NO}_{\mathrm{x}}$ concentrations than the parent coal. An explanation for this phenomenon is related to the CEPS bench-scale combustion test system. Generally, the higher volatiles and moisture content of biomass fuels will tend to lower $\mathrm{NO}_{\mathrm{x}}$ concentrations when cofired with coal. The high volatiles content will create a fuel-rich, oxygen-lean combustion zone by fixing the oxygen much like a low- $\mathrm{NO}_{\mathrm{x}}$ overfire air combustion system while the higher moisture content will lower combustion temperatures and lower thermal $\mathrm{NO}_{\mathrm{x}}$. In the CEPS, the combustion temperature is not solely dependent on the flame since the entire furnace length is externally heated to ensure complete combustion. This may allow the combustion temperature to be maintained at a higher temperature than would be anticipated with no external heating. This would, in turn, increase the thermal $\mathrm{NO}_{\mathrm{x}}$ generation in the combustion zone.

The sulfur levels were much lower in the biomass fuels, and this was directly reflected in the $\mathrm{SO}_{2}$ emissions observed.

The PCQUEST model predicts a slightly higher propensity for high-temperature fouling and slagging with the sunflower hull blends and a very slightly higher propensity with the wood blends when compared to the coal. This is exactly what was seen in the experimentally derived deposit strength development.

PCQUEST focuses primarily on deposit strength and not growth. Deposits can grow and accumulate at a high rate but have such low bonding strength that they fall off heat-transfer surfaces. The 60-40 coal-sunflower hull blend showed slightly harder and denser ash deposits with lowerviscosity phases available for sintering compared to the baseline coal and coal-wood chip blends. With respect to deposit growth, predicted indices and bench-scale CEPS testing showed no appreciable effect of sunflower hull blending and a decrease in deposition rate with wood chip blends.

The current models used for predicting the behavior of coals in combustion environments need to be further refined for better sensitivity to coal-biomass blends. PCQUEST was initially developed for predicting ash behavior for conventional coal-fired systems. Sensitivity to biomass firing in conventional systems needs to be added to PCQUEST, especially with respect to the role that potassium, phosphorus, and reactive biomass silica have in forming molten ash components in entrained fly ash and in ash deposits. 
One of the objectives of Task 4 was to make suggestions and recommendations for the pilotscale combustion tests evaluating coal-biomass cofiring in Task 5. However, these recommendations are valid for future pilot-scale combustion tests as well as full-scale demonstration tests and include the following:

1) Tests should be performed at realistic coal-biomass blend ratios in order to obtain useful performance data.

2) Provisions should be made during combustion tests on baseline fuels and fuel blends to collect fine particulate data including size-segregated samples (ash and condensed species in impactor or multicyclone stages and filter) for analysis. This information will be critical to understanding the role of fine particulate and homogeneous or heterogeneous condensed species in forming initial fine ash deposits or fine particulate that could be difficult to control. Species of concern in the fine particulate are potassium chloride, potassium sulfate, potassium or calcium phosphates, and possibly others.

3) $\mathrm{NO}_{x}$ and $\mathrm{SO}_{x}$ should be measured for the baseline fuel and fuel blends. $\mathrm{NO}_{\mathrm{x}}$ numbers measured in the CEPS combustion equipment were higher than expected. This may be due to external heating of the combustion zone in the CEPS, which could artificially raise the combustion temperature, increasing the production of thermal $\mathrm{NO}_{\mathrm{x}}$. This needs to be tested and verified.

4) With the low fouling and slagging tendencies of the typical $20 \%$ biomass blends, it was recommended to fire the $\mathrm{CTF}$-stoker using $40 \%$ biomass so that any ash deposition effects could be observed.

\section{Task 5 - Pilot-Scale Testing}

Based on the results of the laboratory-scale work, two coal-biomass cofiring tests were completed for Task 5 using the pilot-scale grate-fired system as well as one baseline coal-fired test. The primary fuel was Cordero Rojo subbituminous coal. Each of the two biomass fuels, wood chips and sunflower hulls, were fired at nominally $40 \mathrm{wt} \%$ based on the laboratory-scale combustion test results.

Ash deposition on convective surfaces was minimal for all tests, baseline coal as well as the coal-biomass cofiring tests. Only a few grams of ash were sticking to the ash deposition probe, and the material was mostly calcium and potassium sulfates. The resulting deposition observed would not significantly reduce the capability of a boiler to produce steam.

Deposition characteristics indicated that the high calcium in the coal-wood blend and the high potassium in the coal-sunflower hull blend could create some lower-viscosity bonding material, but in this pilot-scale stoker system there was little evidence of problematic ash deposition.

FEGTs during the pilot-scale tests ranged from $1021^{\circ}$ to $1065^{\circ} \mathrm{C}\left(1870^{\circ}\right.$ to $\left.1948^{\circ} \mathrm{F}\right)$. Slightly higher $\left(56^{\circ} \mathrm{C}\left[100^{\circ} \mathrm{F}\right]\right)$ FEGTs could trigger more severe fouling. Also, the quantity of fly ash generated during these tests was lower than considered typical for stoker-fired applications. Therefore, these observations may have been influenced by grate clinker formation. In summary, 
the dynamics of the stoker system create cooler burning and flame temperatures, resulting in lower FEGTs, which diminish fouling propensity. A CTF run with the same Cordero coal firing in a pc mode showed much more problematic ash fouling. The CEPS system, which is also run in a pc mode, may have also exacerbated fouling propensity.

The clinker formation and the manual techniques used to dislodge clinkers from the grate and walls led to agitation of the bed, creating an intense combustion environment with well-mixed fuel and air. This led to immediate and dramatic reduction in excess air levels and momentary high CO production and carbon carryover. It is recommended that in future tests adjustments to operating parameters be made to run the bed leaner in combustion air, using higher percentages of overfire air to complete combustion. It is expected that this may lead to a less active bed and lower bed temperatures, resulting in decreased clinker formation and, potentially, lower carbon carryover.

Fly ash PSD was shown to decrease when biomass was blended with the coal. This was expected because of the fine size of the fuel minerals in the biomass and the preponderance of organically associated alkali metals and alkaline-earth components. In terms of fly ash generation, the alkalies can be expected to form fine particulates in the form of potassium sulfate, potassium phosphate, chlorides, and calcium sulfate, among other fine species.

The shift to a finer fly ash particle size, as a result of biomass cofiring, could be problematic for units with small ESPs or, in some cases, old stokers still using multicyclones for particulate control. It is recommended that units lacking adequate ESP surface or using multicyclones consider ESP upgrades or installation of fabric filters for collection of fine particulate to meet emissions standards.

Gaseous emissions of both $\mathrm{SO}_{2}$ and $\mathrm{NO}_{x}$ were shown to decrease relative to the baseline coal when biomass was introduced as part of the fuel mix. Both biomass fuels contained lower sulfur contents than did the coal, and the higher alkaline content of the biomass led to increased sulfur capture in the ash. Nitrogen oxide emissions were reduced $20 \%$ during combustion of the coal-wood chip blend and $10 \%$ during combustion of the coal-sunflower hull blend. However, the higher FEGT observed during the coal baseline test may have been a contributing factor to the $\mathrm{NO}_{\mathrm{x}}$ emissions observed.

Overall, the pilot-scale stoker-fired system was shown to work well with respect to achieving desired combustion conditions. Problems were noted with biomass fuel feed and clinker formation. Both of these problems were overcome using manual mitigation techniques at regular intervals. However, for biomass cofiring in the pilot-scale grate-fired system, it is recommended that future projects consider installing a separate feed system to convey the biomass onto the grate. One option worth considering is a screw feed system that would deliver biomass fuel to the front of the grate.

For future pilot-scale combustion tests, operating conditions should be reviewed on an individual fuel basis concerning air distribution, grate versus overfire, and its potential impact on general combustor performance, clinker formation, and fly ash generation.

Further modifications to the pilot-scale grate-fired combustor are likely to improve performance and increase unit flexibility. The primary goal of these modifications would be to decrease metal temperatures on the grate and in the near-grate region. A more sophisticated water- 
cooling system for the grate would help to reduce metal warping and fatigue and would provide better operational control of fuel-bed temperature on the grate. In addition, operational changes would further reduce grate clinkering and result in other improvements in overall combustor performance. Some of these include reducing fuel particle size, reducing the thickness of the fuel bed on the grate, changes in primary and overfire air distribution, and changes to the biomass component of the fuel feed system. The reactive nature of the coal and biomass create an intense combustion environment in the near-grate region. As a result, high bed temperatures were achieved, resulting in clinker formation. A finer particle size, reduction of fuel bed height, and utilizing a greater percentage of overfire air may be expected to greatly increase control of fuel-bed temperatures and reduce ash clinkering. As previously discussed, a screw feeder may be a better option for delivery of some biomass types. Other options may include air-assisted feeder configurations. However, any further modifications or evaluation of operational changes are beyond the scope of this project and would be addressed in future projects.

\subsection{REFERENCES}

1. Mann, M.K.; Spath, P.L. The Net $\mathrm{CO}_{2}$ Emissions and Energy Balances of Biomass and CoalFired Power Systems. In Proceedings of the 4th Biomass Conference of the Americas: Biomass: A Growth Opportunity in Green Energy and Value-Added Products; Overend, R.P.; Chornet, E., Eds.; 1999; Vol. 1, pp 379-385.

2. Bhattacharya, S.C. State of the Art of Biomass Combustion. Energy Sources 1998, 20, 113-135.

3. Easterly, J.L.; Burnham, M. Overview of Biomass and Waste Fuel Resources for Power Production. Biomass Bioenergy 1996, 10 (2-3), 79-92.

4. Turnball, J.H. Strategies for Achieving a Sustainable, Clean and Cost-Effective Biomass Resource. Biomass Bioenergy 1996, 10 (2-3), 93-100.

5. McGowin, C.R.; Wiltsee, G.A. Strategic Analysis of Biomass and Waste Fuels for Electric Power Generation. Biomass Bioenergy 1996, 10 (2-3), 167-175.

6. Bauen, A.; Kaltschmitt, M. Contribution of Biomass Toward $\mathrm{CO}_{2}$ Reduction in Europe. In Proceedings of the 4th Biomass Conference of the Americas: Biomass: A Growth Opportunity in Green Energy and Value-Added Products; Overend, R.P.; Chornet, E., Eds.; 1999; Vol. 1, pp 371-378.

7. Kwant, K.W.; van Leenders, C. Developments of Green Energy Market in the Netherlands and the Perspectives of Biomass. In Proceedings of the 4th Biomass Conference of the Americas: Biomass: A Growth Opportunity in Green Energy and Value-Added Products; Overend, R.P.; Chornet, E., Eds.; 1999; Vol. 1, p 1629.

8. Frandsen, F.J.; Nielsen, H.P.; Jensen, P.A.; Hansen, L.A.; Livbjerg, H.; Dam-Johansen, K.; Sorensen, H.S.; Larsen, O.H.; Sander, B.; Henriksen, N.; Simonsen, P. Deposition and Corrosion in Straw- and Coal-Straw Co-Fired Utility Boilers. In Proceedings of the Engineering 
Foundation Conference on the Impact of Mineral Impurities in Solid Fuel Combustion; Kona, HI, Nov 2-7, 1997; Wall, T.F.; Baxter, L.L., Eds.; 1997; 14 p.

9. Frandsen, F.J.; Nielsen, H.P.; Hansen, L.A.; Hansen, P.F.B., Andersen, K.H., Sorensen, H.S. Ash Chemistry Aspects of Straw and Coal-Straw Cofiring in Utility Boilers. In Proceedings of the 15th Annual International Pittsburgh Coal Conference; Sept 14-18, 1998; 14 p.

10. Skrifvar, B.; Lauren, T.; Backman, R.; Hupa, M. The Role of Alkali Sulfates and Chlorides in Post Cyclone Deposits from Circulating Fluidized Bed Boilers Firing Biomass and Coal. In Proceedings of the Engineering Foundation Conference on the Impact of Mineral Impurities in Solid Fuel Combustion; Kona, HI, Nov 2-7, 1997; Wall, T.F.; Baxter, L.L., Eds.; 1997; 10 p.

11. Jensen, P.A.; Stenholm, J.; Hald, P. Deposition Investigation in Straw-Fired Boilers. Energy Fuels 1997, 11, 1048-1055.

12. Olanders, B.; Steenari, B. Characterization of Ashes from Wood and Straw. Biomass Bioenergy 1995, $8(2), 105-115$.

13. Nordin, A. Chemical Elemental Characteristics of Biomass Fuels. Biomass Bioenergy 1995, 8 (2), 339-347.

14. Boylan, D.M. Southern Company Tests of Wood/Coal Cofiring in Pulverized Coal Units. Biomass Bioenergy 1996, 10 (2-3), 139-147.

15. Brouwer, J.; Owens, W.D.; Harding, S.; Heap, J.P. Cofiring Waste Biofuels and Coal for Emission Reduction. In Proceedings of the 2nd Biomass Conference of the Americas: Energy, Environment, Agriculture, and Industry; Portland, OR, Aug 21-24, 1995; NREL/CP-200-8098, DE95009230; 1995; pp 390-399.

16. Rudinger, H.; Kicherer, A.; Greul, U.; Spliethoff, H.; Hein, K.R.G. Investigations in Combined Combustion of Biomass and Coal in Power Plant Technology. Energy Fuels 1996, 10, 789-796.

17. Hughes, E.; Tillman, D. Biomass Cofiring: Status and Prospects 1996. In Proceedings for the Engineering Foundation Conference, Biomass Usage for Utility and Industrial Power; Snowbird, UT, April 28 - May 3, 1996; 19 p.

18. Battista, J.; Tillman, D.; Hughes, E. Cofiring Wood Waste with Coal in a Wall-Fired Boiler: Initiating a 3-Year Demonstration Program. In Proceedings of BioEnergy 98: Expanding BioEnergy Partnerships; Madison, WI, Oct 4-8, 1998; pp 243-250.

19. Moore, T. Harvesting the Benefits of Biomass. EPRI Journal 1996, May/June, 16-25.

20. Prinzing, E.E.; Hunt, E.F. Impacts of Wood Cofiring on Coal Pulverization at the Shawville Generating Station. In Proceedings of the Engineering Foundation Conference: Biomass Usage for Utility and Industrial Power; Snowbird, UT, April 28 - May 3, 1996; 15 p. 
21. Gold, B.A.; Tillman, D.A. Wood Cofiring Evaluation at TVA Power Plants. Biomass Bioenergy 1996, $10(2-3), 71-78$.

22. Miles, T.R.; Miles, T.R., Jr.; Baxter, L.L.; Bryers, R.W.; Jenkins, B.M.; Oden L.L. Boiler Deposits from Firing Biomass Fuels. Biomass Bioenergy 1996, 10 (2-3), 125-138.

23. Moe, T.A. Wastepaper Pellets as a Source of Fuel for Auxiliary Home Heating; Final Report for Western Area Power Administration; Energy \& Environmental Research Center: Grand Forks, ND, June 1995; $21 \mathrm{p}$.

24. Miles, T.R.; Miles, T.R., Jr.; Baxter L.L.; Bryers, R.W.; Jenkins, B.M.; Oden, L.L. Boiler Deposit from Firing Biomass Fuels. Biomass Bioenergy 1996, 10 (2-3), 125-138.

25. Aerts, D.J.; Ragland, K.W. Cofiring Switchgrass in a 50-MW Pulverized Coal Utility. In Proceedings of BioEnergy 98: Expanding BioEnergy Partnerships; Madison, WI, Oct 4-8, 1998; pp 295-305.

26. Segrest, S.A.; Rockwood, D.L.; Stricker, J.A.; Green, A.E.S.; Smith, W.H.; Carter, D.R. Biomass Cofiring with Coal at Lakeland, Florida, Utilities. In Proceedings of BioEnergy 98: Expanding BioEnergy Partnerships; Madison, WI, Oct 4-8, 1998; pp 315-325.

27. Kendall, A. Barriers to the Progress of Bioenergy. Energy World 1996, May, 10-13.

28. Graham, R.L.; Lichtenberg, E.; Roningen, V.O.; Shapouri, H.; Walsh, M.E. The Economics of Biomass Production in the United States. In Proceedings of the 2nd Biomass Conference of the Americas: Energy, Environment, Agriculture, and Industry; Portland, OR, Aug 21-24, 1995; NREL/CP-200-8098, DE95009230; 1995; pp 1314-1323.

29. Sondreal, E.A.; Benson, S.A.; Hurley, J.P.; Mann, M.D.; Pavlish, J.H.; Swanson, M.L.; Weber, G.F.; Zygarlicke, C.J. Review of Advances in Combustion Technology and Biomass Firing. Fuel Process. Technol. 2001, 71 (1-3), 7-38.

30. Piperno, D.R. Phytolith Analysis; Academic Press: New York, 1988.

31. Baxter, L.L.; Miles, T.R.; Miles Jr., T.R.; Jenkins, B.M.; Milne, T.; Dayton, D.; Bryers, R.W.; Oden., L.O. The Behavior of Inorganic Material in Biomass-Fired Power Boilers: An Overview of the Alkali Deposits Project. In Bridgwater, A.V., Boocock, D.G.B., Eds.; Developments in Thermochemical Biomass Conversion; Blackie Academic \& Professional: London; Vol II, pp 1424-1444; NICH Report No. 24259.

32. Robinson, A.; Baxter, L.; Junker, H.; Shaddix, C.; Freeman, M.; James, R.; Dayton, D. Fireside Issues Associated with Coal-Biomass Cofiring. Presented at BioEnergy '98, Madison, WI, Oct 4-8, 1998.

33. Kautz, K.M. Slagging, Fouling, and Corrosion on the New Generation of German Boilers Designed for the Combustion of a Broad Range of Bituminous Coal of Worldwide Origin. In 
Proceedings of the Engineering Foundation Conference: Fouling of Heat Exchanger Surfaces; Bryers, R.W. Ed.; United Engineering Trustees, Inc., 1983; pp 371-388.

34. Williams, R.B.; Jenkins, B.M.; Bakker, R.R.; Baxter, L.L. Investigation of Superheater Fouling in Biomass Boilers with Furnace Exit Gas Temperature Control. In Proceedings of the 4th Biomass Conference of the Americas: Biomass: A Growth Opportunity in Green Energy and Value-Added Products; Overend, R.P.; Chornet, E., Eds.; 1999; Vol. 2, pp 1393-1399.

35. Frandsen, F.J.; Nielsen, H.P.; Jensen, P.A.; Hansen, L.A.; Livbjerg, H.; Dam-Johansen, K.; Sorensen, H.S.; Larsen, O.H.; Sander, B.; Henriksen, N.; Simonsen, P. Deposition and Corrosion in Straw-and Coal-Straw Co-Fired Utility Boilers. In Proceedings of the Engineering Foundation Conference on the Impact of Mineral Impurities in Solid Fuel Combustion; Kona, HI, Nov 2-7, 1997; Wall, T.F.; Baxter, L.L., Eds.; 1997; 14 p.

36. Nielsen-Philbert, H. Deposition and High-Temperature Corrosion in Biomass-Fired Boilers, Ph.D. Thesis, Technical University of Denmark, Department of Chemical Engineering, Nov $1998,126 \mathrm{p}$.

37. Obernberger, I.; Dahl, J.; Brunner, T. Formation, Composition and Particle Size Distribution of Fly-Ashes from Biomass Combustion Plants. In Proceedings of the 4th Biomass Conference of the Americas: Biomass: A Growth Opportunity in Green Energy and Value-Added Products; Overend, R.P.; Chornet, E., Eds.; 1999; Vol. 2, pp 1377-1384.

38. Folkedahl, B.C.; Zygarlicke, C.J.; Hutton, P.N.; McCollor, D.P. Biomass for EnergyCharacterization and Combustion Ash Behavior. In Proceedings of Power Production in the 21st Century: Impacts of Fuel Quality and Operations; Harding, N.S.; Baxter, L.L.; Wigley, F.; Frandsen, F., Eds.; Snowbird, UT, Oct 28 - Nov 2, 2001.

39. Folkedahl, B.C.; Zygarlicke, C.J., Strege, J. Influence of Biomass Cofiring on $\mathrm{PM}_{2.5}$ Ash Produced in a 7-kW Coal Combustion System. Presented at the NETL PM ${ }_{2.5}$ Conference, Pittsburgh, PA, April 9-10, 2002, 2 p.

40. Zygarlicke, C.J.; Pavlish, J.H.; Laumb, J.D. Fuel and Combustion Characteristics of Rice Straw Lignin. To be presented at Bioenergy 2002: Bioenergy for the Environment, Boise, ID, Sept 22-26, 2002.

41. Zygarlicke, C.J.; McCollor, D.P.; Toman, D.L.; Dahl, J. Ash Interactions During the Cofiring of Biomass with Fossil Fuels. In Proceedings of the 26th International Technical Conference of Coal Utilization, and \& Fuel Systems; Clearwater, FL, March 5-8, 2001; pp 237-248.

42. Zygarlicke, C.J.; Pavlish, J.H.; Laumb, J. Suitability of Rice Straw Lignin as Boiler Fuel. In Proceedings of the 5th Biomass Conference of the Americas, Bioenergy and Biobased Products: Technologies, Markets, and Policies; Orlando, FL, Sept 17-21, 2001; 2 p.

43. Zygarlicke, C.J.; Pavlish, J.H.; Gunderson, J.R.; McCollor, D.P. Ash Behavior and Combustion Performance During the Cofiring of Rice Straw Lignin and Coal. In Proceedings of the 9th 
Biennial Bioenergy Conference: Moving Technology into the Marketplace; Buffalo, NY, Oct 15-19, 2000; 12 p.

44. Zygarlicke, C.J.; Eylands, K.E.; McCollor, D.P.; Musich, M.A.; Toman, D.L. Impacts of Cofiring Biomass with Fossil Fuels. In Proceedings of the 25th International Technical Conference on Coal Utilization and Fuel Systems; Clearwater, FL, March 6-9, 2000; pp 115-126.

45. Electricity from Biomass: National Biomass Power Program Five-Year Plan (FY 1994-FY 1998); Solar Thermal and Biomass Power Division, Office of Solar Energy Conversion, U.S. Department of Energy, U.S. Government Printing Office: Washington, DC, 1993; 43 p.

46. Mann, M.D. Modular Fluid Bed Biocombustor - Phase 1 and 1 A Final Report; Final Report for Sandia National Laboratories Contract No. BC-0002C; EERC Publication 99-EERC-12-03; Energy \& Environmental Research Center: Grand Forks, ND, 1999; 67 p.

47. Schmidt, D.D.; Pinapati, V.S. Opportunities for Small Biomass Power Systems; Final Technical Report for U.S. Department of Energy Contract No. DE-FG02-99EE35128; EERC Publication 2000-EERC-11-01; Energy \& Environmental Research Center: Grand Forks, ND, Nov 2000.

48. Jenkins, B. University of California-Davis. Personal communication, Dec 2000.

49. Obernberger, I.; Dahl, J. University of Graz-Austria. Personal communication, Dec 2000.

50. Frandsen, F. Technical University of Denmark. Personal communication, May 2000.

51. Kiel, J. Energy Research Foundation of the Netherlands. Personal communication.

52. Reidl, R.; Dahl, J.; Obernberger, I.; Narodoslawsky, M. Corrosion in Fire-Tube Boilers of Biomass Combustion Plants. In Proceedings of the China International Corrosion Control Conference 1999; Beijing, China; Oct 1999, China Chemical Anticorrosion Technology Association (CCATA) Paper No. 90129, Beijing, China.

53. Benson, S. Microbeam Technologies Incorporated. Personal communication, Dec 2000.

54. Hinman, N. BCI International. Personal communication, Oct 2000.

55. Wood P.; McFadden, M. Ogden Power Pacific, Inc. Personal communication, June 1999.

56. Baxter, L. Brigham Young University. Personal communication, Dec 2000.

57. Schmidt, D.D.; Pavlish, J.H.; Plasynski, S. Biomass Cofiring: Low-Rank Coal and District Energy Cogeneration. Cogeneration and On-Site Power Production 2001, 2 (6).

58. Hutton, P.N. Cofiring of Biomass at the University of North Dakota; Final Report for U.S. Department of Energy Contract No. DE-FC26-00NT40807; EERC Publication 2002-EERC-0101; Energy \& Environmental Research Center: Grand Forks, ND, Jan 2002. 
59. Schmidt, D.D. Cofiring of Biomass with Lignite Coal; Final Report for U.S. Department of Energy Contract No. DE-FC26-00NT40900; EERC Publication 2002-EERC-01-03; Energy \& Environmental Research Center: Grand Forks, ND, Jan 2002.

60. Bird, J. North Dakota Forest Service. Personal communication, Nov 2000.

61. Sondreal, E.A.; Benson, S.A.; Hurley, J.P.; Mann, M.D., Pavlish, J.H.; Swanson, M.L., Weber, G.F.; Zygarlicke, C.J. Review of Advances in Combustion Technology and Biomass Cofiring. Presented at the Coal Technology and Utilization Conference, Ankara, Turkey, April 14-15, 2000.

62. Schmidt, D.D. Opportunities for Small Biomass Power Systems. Presented at the Bioenergy 2000 Conference, Buffalo, NY, Oct 15-19, 2000.

63. Folkedahl, B.C.; Zygarlicke, C.J.; Strege, J. Influence of Biomass Cofiring on PM $_{2.5}$ Ash Produced in a 7-kW Coal Combustion System. Presented at $\mathrm{PM}_{2.5}$ Electric Power Generation: Recent Findings and Implications, Pittsburgh, PA, April 9-10, 2002.

64. EPRI Biannual Biomass Interest Group Meeting, Washington, DC, June 6-7, 2001.

65. EPRI Biannual Biomass Interest Group Meeting, Washington, DC, Nov 15-16, 2001.

66. EPRI Biannual Biomass Interest Group Meeting, Provo, UT, April 14-15, 2002. 
APPENDIX A

\section{DESCRIPTION OF THE CEPS}




\section{DESCRIPTION OF THE CONVERSION AND ENVIRONMENTAL PROCESS SIMULATOR}

The Energy \& Environmental Research Center (EERC) has been performing controlled combustion tests using bench- and pilot-scale test combustors for many years. These include droptube furnace systems (atmospheric and pressurized) that burn grams of fuel per minute and pilotscale units that burn 50-75 pounds of fuel per hour. Recently, the EERC has built an intermediatescale combustor that will effectively operate at $1-5$ pounds of fuel per hour. This system (Figure A1 ) is termed the conversion and environmental process simulator (CEPS).

The CEPS is an extremely versatile system, which can generate realistic combustion test results for a variety of fuels and combustion conditions. The intermediate size of the system and its relatively simple operation ensure adequate quantities of actual flue gas and ash for analysis in a relatively short period of time. Specific applications for this system include fuel and combustion system impacts on air pollutant formation and prevention, residual ash disposal and reuse, combustion rates and efficiencies, and furnace slagging and fouling. The CEPS is especially designed for sensitive measurement of trace element species in flue gas, with detection limits of less than one part per million. Combustion testing of both coal and fuel oil under various conditions has been successful to date. However, the CEPS is not limited to these fuels. Other fuels that can be tested include coal-water fuels; petroleum coke; orimulsion; black liquor; biomass such as wood pellets, hay, alfalfa, or tree bark; and waste materials such as sludge and municipal solid waste. The CEPS is currently equipped with a baghouse, but soon will also have the capability of operating with a small wet scrubber system. These scaled-down versions of particulate and $\mathrm{SO}_{2}$ control systems will be used to determine emissions factors and removal efficiencies for toxic metal and other air toxic emissions.

When designing the CEPS, it was found that many similar intermediate-scale furnaces currently in operation have trouble attaining and maintaining high gas temperatures in the main combustion zones from the fuel alone. Acute control of gas temperatures and composition throughout the CEPS furnace is possible independent of the heat capacity of the fuel because of the external heating capacity of CEPS. Heating elements line the main furnace, convective pass section, and baghouse chambers. Temperatures of the flue gas (approximately 5-10 scfm) can attain a maximum of $1500^{\circ}-1600^{\circ} \mathrm{C}\left(2732^{\circ}-2912^{\circ} \mathrm{F}\right)$ in the radiant section and can be maintained at $760^{\circ}-1200^{\circ} \mathrm{C}\left(1400^{\circ}-2200^{\circ} \mathrm{F}\right)$ in the convective pass section and $120^{\circ}-250^{\circ} \mathrm{C}\left(248^{\circ}-482^{\circ} \mathrm{F}\right)$ in the baghouse, with the capability to go higher. The CEPS was also designed with the sampling of trace elements in mind. The entire system is lined with either ceramic or refractory material, eliminating the possibility of reaction with and contamination of metal surfaces. There is ample access for sampling, observation, and optical diagnostics through access ports located throughout the CEPS. A personal computer (PC) displays and records temperatures, gas flows, feed rates, and flue gas compositions. Flue gas $\left(\mathrm{O}_{2}, \mathrm{CO}_{2}, \mathrm{CO}, \mathrm{SO}_{2}\right.$, and $\left.\mathrm{NO}_{\mathrm{x}}\right)$ compositions are sampled from ports in the radiant section and after the collection device.

The CEPS is a downfired design for nominally top-firing $4.0 \mathrm{lb} / \mathrm{hr}(1.8 \mathrm{~kg} / \mathrm{hr})$ of pulverized coal or $1.5 \mathrm{lb} / \mathrm{hr}$ of oil with a heat output of $\sim 30,000 \mathrm{Btu} / \mathrm{hr}$. Several injection systems allow other solid or liquid fuels to be utilized. It is a modular system capable of simulating conditions of both the radiant and convective sections of a full-scale utility boiler. The electrically heated 12 -ft vertical 


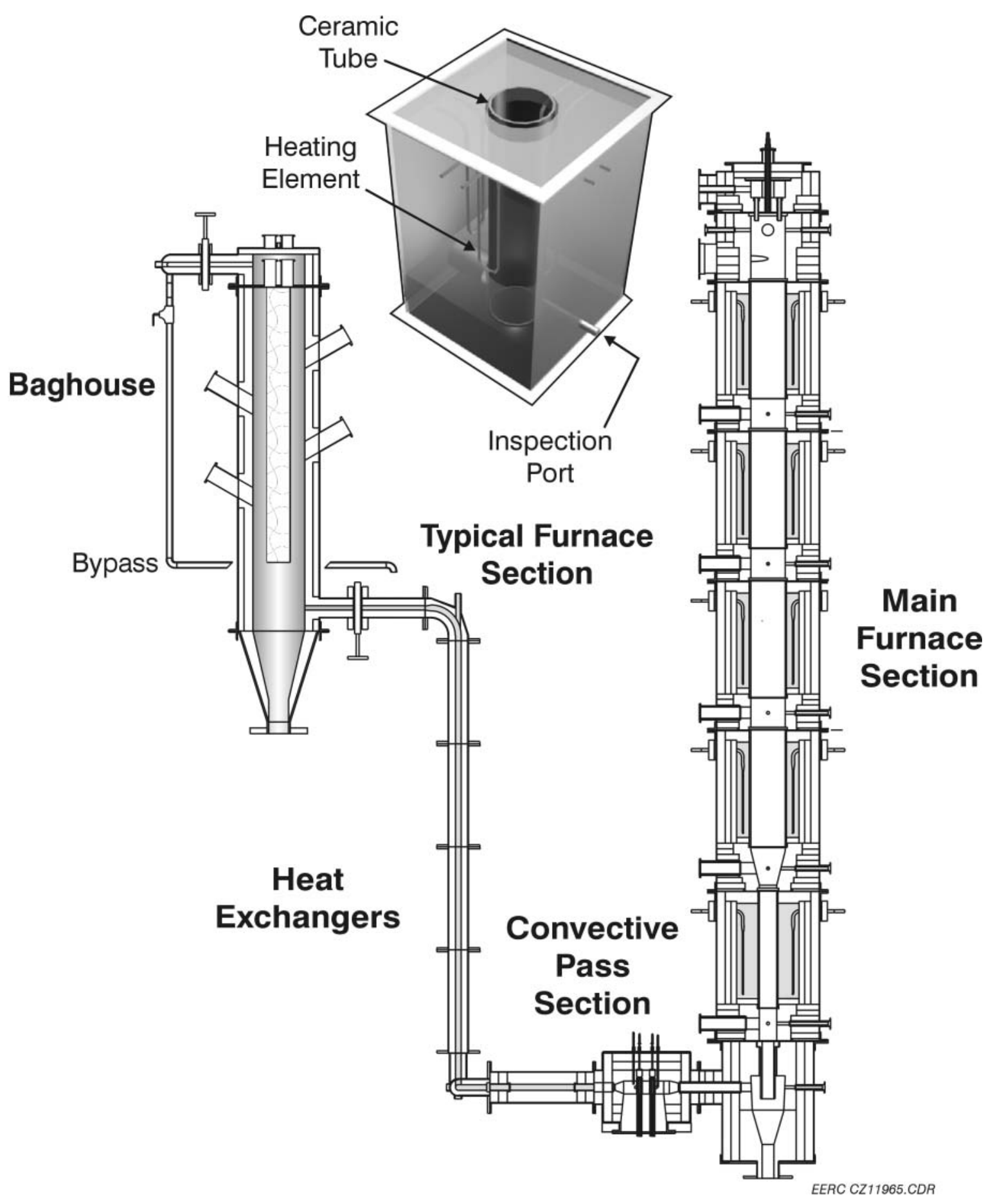

Figure A-1. Design sketch of the CEPS showing the main and convective pass section, heat exchangers, and baghouse. 
radiant furnace portion has an inside diameter of 6 in. for the first $9 \mathrm{ft}$, with the final heated section diameter reduced to 3 in. The radiant zone exit is through a horizontal 1.5-in.-inside-diameter ceramic tube. A portion of the particulate is removed before going onto the convective pass section, which includes an optional ash-fouling test section. From the convective section, the flue gas flows through several refractory-lined heat exchangers, the particulate collection device, an air eductor, and a stack that exits through the roof of the building.

The combustion air is split into primary and secondary air. $20 \%-25 \%$ of the air is introduced into the system as primary air and is used to carry the fuel into the CEPS. The secondary combustion air is preheated to a maximum of $850^{\circ} \mathrm{C}$ and can be introduced into the CEPS vertically or tangentially. Five electrically heated furnace sections comprise the main portion of the radiant furnace section and are constructed using a combination of ceramic tubes set into cast abrasionresistant refractory. The refractory sections have access ports that are used for pressure and temperature measurements, injection of solids or gases, sampling of gaseous or particulate emissions, deposition, observation, and optical analyses. The ceramic tubes are exposed to molybdenum disilicide heating elements, allowing operation to $1500^{\circ} \mathrm{C}$. High-temperature, fibrous insulating boards surround the high-temperature components housed inside the stainless steel shells.

At the exit of the radiant section is a bottom (unheated) furnace section designed to remove and collect the larger ash particles prior to entering the horizontally oriented convective pass. The convective pass is about $4 \mathrm{ft}$ in length and constructed of a combination of ceramic tubing, refractory, and high-temperature fibrous insulating boards. There is the capability for studying deposition in the convective pass with two in-series, highly instrumented air-cooled probes.

After the convective section, flue gas flows through a series of heat exchangers and then on to the particulate control device, which is a baghouse, wet scrubber, or cyclone. Flue gas temperatures are well-controlled going into the control device section for typical operation at $250^{\circ}-350^{\circ} \mathrm{F}$, and flexibility has been built into the system to allow experimentation at even higher flue gas temperatures. Beyond the control device, the flue gas proceeds through an air eductor and up to a stack through the top of the roof of a new pilot plant facility at the EERC. The system is designed so that the control devices can be interchanged without major system modifications. 


\section{APPENDIX B}

\section{FACT MODELING RESULTS}

(Refers to Task 4 Modeling of sunflower hull and wood chip blends with coal. The focus is on predicting liquid-phase viscosities and amounts of liquid phase at various temperatures.) 

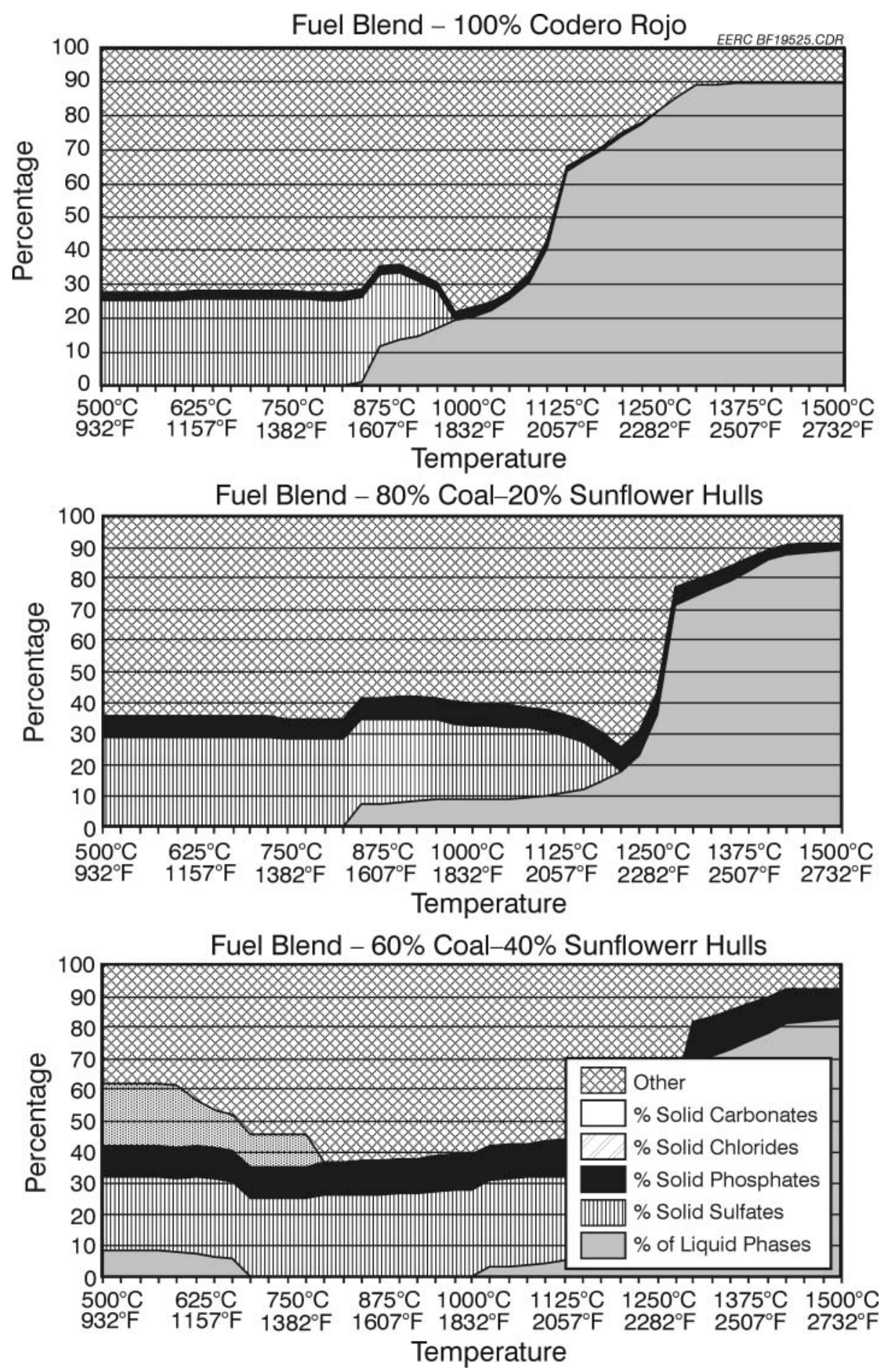

Figure B1. Liquid-solid-phase diagram as predicted by the FACT modeling software. 
Fuel Blend - $100 \%$ Sunflower Hulls
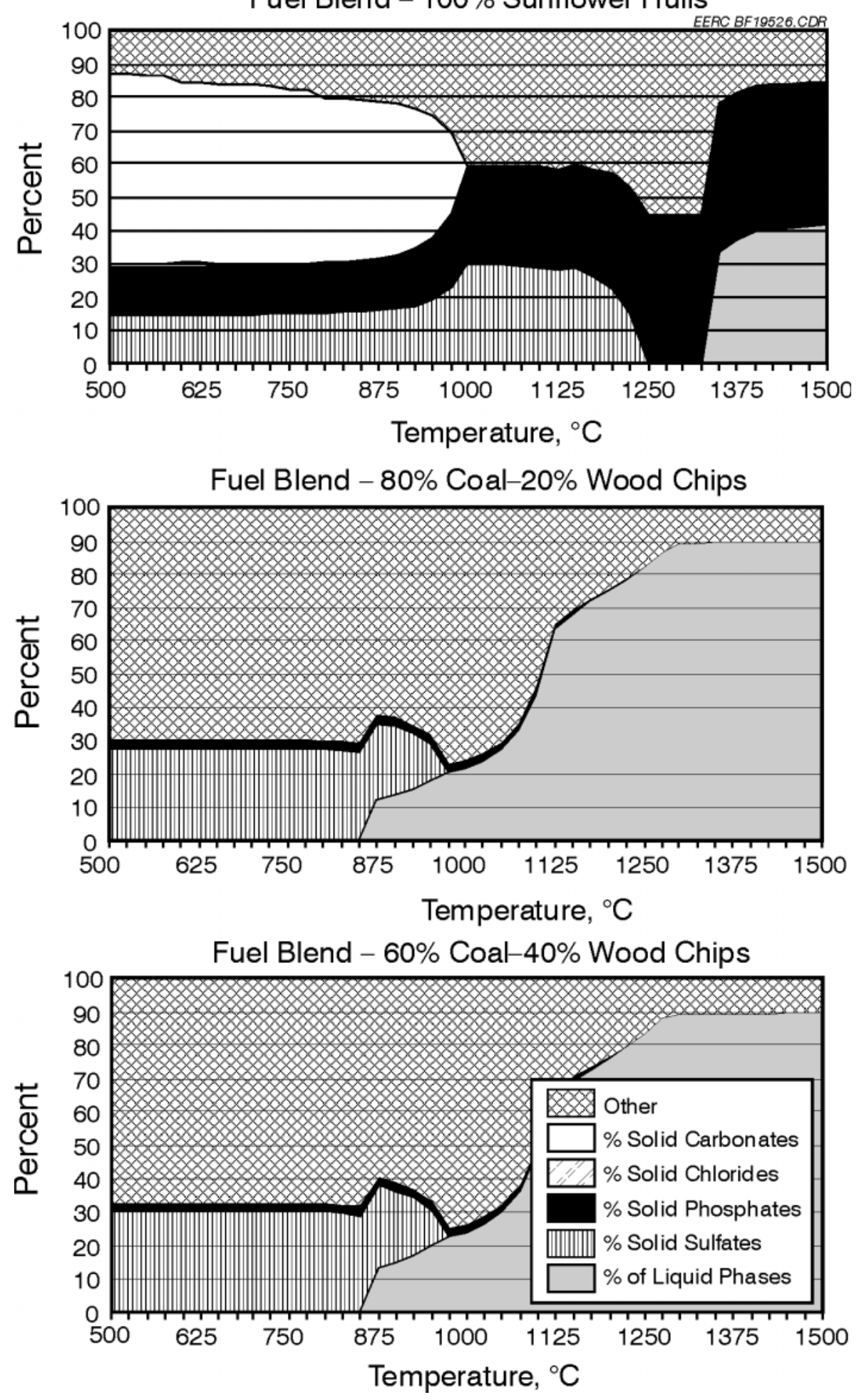

Figure B1 (continued). Liquid-solid-phase diagram as predicted by the FACT modeling software. 


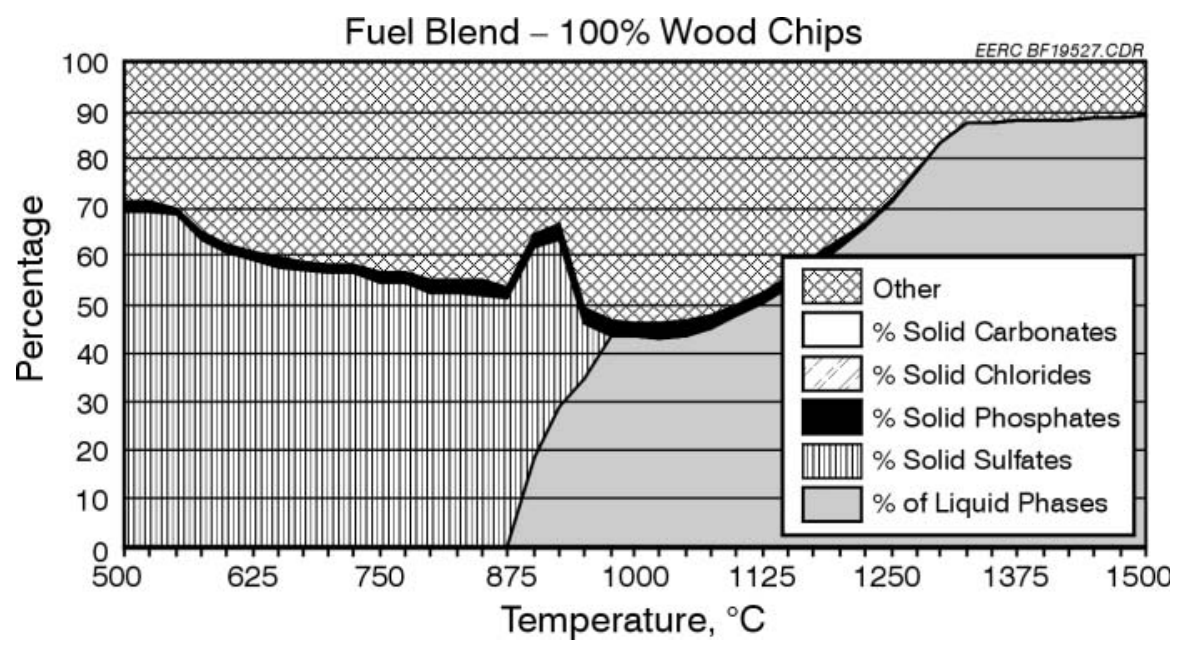

Figure B1 (continued). Liquid-solid-phase diagram as predicted by the FACT modeling software.
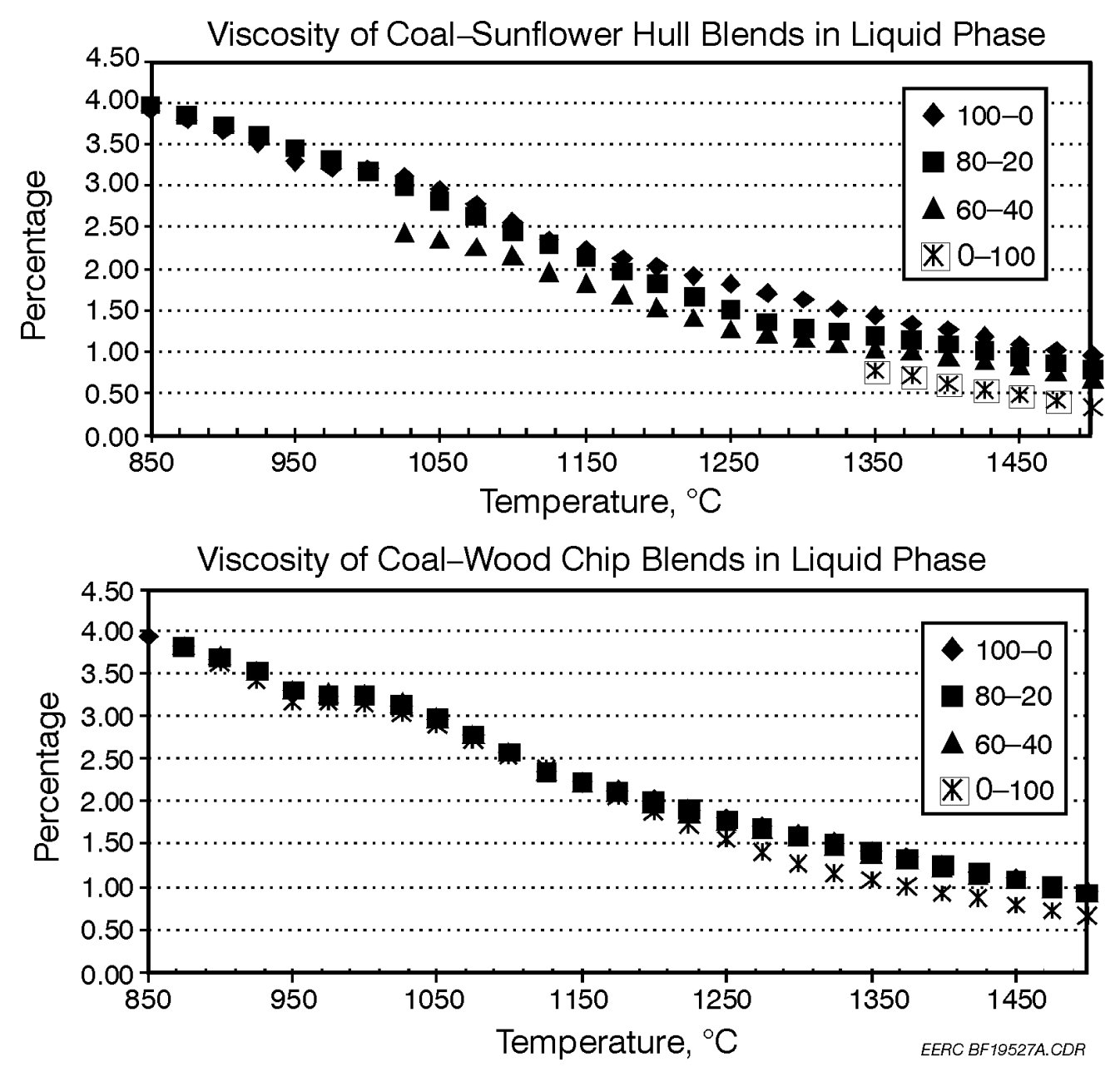

Figure B2. Viscosity of coal-sunflower hull blends in liquid phase. 